\author{
UNIVERSIDADE DE SÃO PAULO \\ FACULDADE DE FILOSOFIA, LETRAS E CIÊNCIAS HUMANAS \\ DEPARTAMENTO DE LINGUÍSTICA
}

\author{
ALEXANDRE MARCELO BUENO
}

\title{
Representações discursivas do imigrante no Brasil a partir de 1945
}

\author{
Versão corrigida \\ (original encontra-se disponível no Centro de Apoio à Pesquisa Histórica da \\ FFLCH-USP)
}

Orientadora: Profa. Dra. Diana Luz Pessoa de Barros

Tese apresentada ao Programa de Pós-Graduação em Semiótica e Linguística Geral da Faculdade de Filosofia, Letras e Ciências Humanas da Universidade de São Paulo para a obtenção do Título de Doutor em Semiótica e Linguística Geral 


\title{
Representações discursivas do imigrante no Brasil a partir de 1945
}

\author{
Versão corrigida \\ (original encontra-se disponível no Centro de Apoio à Pesquisa Histórica da \\ FFLCH-USP)
}

De acordo:

Profa. Dra. Diana Luz Pessoa de Barros

Tese apresentada ao Programa de Pós-Graduação em Semiótica e Linguística Geral da Faculdade de Filosofia, Letras e Ciências Humanas da Universidade de São Paulo para a obtenção do Título de Doutor em Semiótica e Linguística Geral

Área de Concentração: Semiótica e Linguística Geral

Orientadora: Profa. Dra. Diana Luz Pessoa de Barros

São Paulo 2011 
Autorizo a reprodução e divulgação total ou parcial deste trabalho, por qualquer meio convencional ou eletrônico, para fins de estudo e pesquisa, desde que citada a fonte.

Catalogação na Publicação

Serviço de Biblioteca e Documentação

Faculdade de Filosofia, Letras e Ciências Humanas da Universidade de São Paulo

Bueno, Alexandre Marcelo

Representaçoses discursivas do imigrante no Brasil

B928r a partir de 1945 / Alexandre Marcelo Bueno;

orientadora Diana Luz Pessoa de Barros. - Sáo Paulo, 2011.

$341 \mathrm{f}$.

Tese (Doutorado) - Faculdade de Filosofia, Letras e Ciências Humanas da Universidade de São Paulo.

Departamento de Linguística. Área de concentração: Semiótica e Lingüistica Geral. 


\section{Folha de Aprovação}

BUENO, Alexandre Marcelo (alexandrembueno@gmail.com)

Representações discursivas do imigrante no Brasil a partir de 1945

Tese apresentada ao Programa de Pós-Graduação em Semiótica e Linguística Geral da Faculdade de Filosofia, Letras e Ciências Humanas da Universidade de São Paulo para a obtenção do Título de Doutor em Semiótica e Linguística Geral

Aprovada em:

\section{Banca examinadora:}

Prof(a). Dr(a).: Instituição:

Julgamento: Assinatura

$\operatorname{Prof}(\mathrm{a}) . \operatorname{Dr}(\mathrm{a})$ : Instituição:

Julgamento: Assinatura

Prof(a). Dr(a).: Instituição:

Julgamento: Assinatura

Prof(a). Dr(a).: Instituição:

Julgamento: Assinatura

Prof(a). Dr(a).: Instituição:

Julgamento: Assinatura 
A todos os imigrantes, de ontem, de hoje e de amanhã 


\section{Agradecimentos}

O momento de agradecer nos permite relembrar todos os que, de forma direita ou indireta, contribuíram com o desenvolvimento deste trabalho. $\mathrm{E}$, mais importante, nos mostra que a caminhada não foi realizada sozinho.

Agradeço inicialmente à CAPES pela bolsa de doutorado e pela bolsa de estágio no exterior, auxílios fundamentais para o desenvolvimento deste trabalho. Ao Laboratório de Estudos sobre a Intolerância (LEI-USP) por todo o auxílio.

Aos professores Horácio Gutierrez, Sheila Grillo, Maria Lucia de O. Andrade, Maria Luiza Tucci Carneiro, pelos cursos ministrados (fora do Departamento de Linguística) que permitiram um enriquecimento em nosso trabalho.

À Erica, ao Ben-Hur e ao Robson, pelo auxílio, competência e gentileza de sempre. E porque eu sei (por experiência própria) o quanto eles são importantes para o funcionamento do Departamento.

Aos professores do Departamento de Linguística e, em especial, à Profa. Olga Coelho, à Profa. Margarida Petter e ao Prof. Luiz Tatit pela oportunidade de realizar o estágio docente e pelos laços que daí surgiram. Aos professores Paulo Chagas, Ana Scher, Esmeralda Negrão e Evani Viotti pela forma sempre educada e gentil com que me tratam.

Aos professores Ivã Lopes e Waldir Beividas, por manterem, com paciência e competência, o GES-USP.

À professora Norma Discini, sobretudo pela conversa que tivemos durante o meu processo de ingresso no doutorado.

Aos professores Gaston Hilgert e Marli Quadros Leite, que me acompanham nessa caminhada desde os primeiros passos do mestrado.

Ao professor Denis Bertrand, meu orientador durante o estágio em Paris, pelo bom humor e pela preocupação com a educação de seus alunos e orientandos. Ao professor Eric Landowski e Juan Alonso, pelos cursos e conversas ocorridas.

Aos colegas de Limoges, Shima, Amir, Vivien e Audrey, que me acolheram muito bem durante o primeiro Colóquio de Jovens Semioticistas. 
Aos amigos do GES-USP, Sueli, Mariana, Francisco, Eliane, Conrado, Ju Di Fiori, pelo sempre agradável convívio que ultrapassa a mera discussão teórica. Aline, Júlio, Renato e Leonor pelas conversas e cafés.

Às amizades feitas ou consolidadas em Paris: Roberlei, Grecie, Fernanda, Laura, Thiago e Pamela, agradeço por tornarem a estadia em terras francesas menos fria e muito mais divertida.

Às ótimas amizades que ganhei na universidade: Marcus Lunguinho, Indaiá, Vitor, Lucia, Eneida, Alvaro, por me mostrarem que a inteligência pode e deve conviver bem com risadas e bom humor.

Aos meus grande amigos, Tamara, Odair, Oriana e Carol Tomasi, que me mostraram que a amizade pode nascer na universidade, mas ela fica muito melhor quando ultrapassa seus muros. Obrigado por toda a força e incentivo nos últimos meses.

Ao Hemerson, Demétrios, Ricardo e Rosemberg, irmãos que a vida me deu.

À minha família e, principalmente, à minha mãe e à minha irmã Valéria. Agradeço todo apoio e paciência nos momentos mais difíceis. Sem vocês duas, eu não teria conseguido.

Por fim, mais do que agradecer, quero expor minha gratidão à orientadora deste trabalho, Profa. Diana Luz Pessoa de Barros. Eu só posso mesmo ser grato por sua paciência, compreensão e generosidade durante esses anos de convívio. Obrigado por acreditar em mim, muitas vezes mais do que eu mesmo acreditei. Se este trabalho tem algum mérito, ele decorre de sua orientação. Quanto aos erros e equívocos, eles são todos de minha responsabilidade. 


\section{RESUMO}

A imigração no Brasil pós-1945 se caracterizou, em um primeiro momento, pela retomada dos grupos imigrantes mais tradicionais (europeus e japoneses). Os europeus, em geral, vieram para o trabalho na agricultura e/ou na indústria na condição de refugiados ou de deslocados de guerra. Com a volta desses imigrantes, a sociedade nacional e o Estado brasileiro retomaram as discussões a respeito do melhor tipo de imigrante para o país. Nesse contexto, constrói-se uma série de representações do imigrante desejável e indesejável. Em um momento posterior, nos anos 1950-1960, o fluxo imigratório prosseguiu com a entrada de imigrantes latino-americanos e asiáticos (coreanos e chineses), que tinham uma qualificação menor do que a desejada pela sociedade nacional e pelo Estado brasileiro. O objetivo de nosso trabalho é o de analisar as representações positivas e negativas do imigrante construídas pela sociedade e pelo Estado brasileiros depois de 1945. Veremos também como a sociedade e Estado brasileiros constroem suas próprias imagens (ser brasileiro) a partir da presença dos imigrantes. Nosso último objetivo será o de examinar possíveis formas de preconceito e de intolerância contra o imigrante no Brasil. O material de nossa análise é constituído por três discursos distintos (jurídico, científico e jornalístico). O primeiro discurso se refere a leis que tratam dos temas da nacionalidade brasileira, do estrangeiro no país e do refugiado. $O$ segundo discurso analisado é o científico, com artigos que tratam da seleção de imigrantes e/ou da interação deles com a sociedade e o Estado brasileiros. O terceiro discurso selecionado é o jornalístico, com reportagens sobre a contribuição dos imigrantes ao país ou de sua interação, bem ou mal sucedida, com brasileiros. Para as análises, utilizamos a semiótica de linha francesa. Dentre as diversas orientações teóricas que a semiótica possui nos dias atuais, selecionamos a semiótica tensiva para explicar a formação dos valores dos discursos que tratam da imigração; a sociossemiótica para entendermos as formas de interação entre imigrantes, sociedade nacional e Estado brasileiro; e a semiótica das paixões para compreendermos como as emoções e os sentimentos são mobilizados na construção das representações do imigrante, da sociedade nacional e do Estado brasileiro.

Palavras-chave: Imigração; História do Brasil depois de 1945; Representação; Tolerância; Intolerância; Semiótica discursiva francesa. 


\begin{abstract}
Immigration in Brazil post-1945 was characterized at first by the resumption of more traditional immigrant groups, such as Europeans and Japanese. The Europeans, in general, came to work in agriculture and / or industry as refugees or as displaced persons. With the return of these immigrants, the national society and the Brazilian state reinitiated the discussions regarding the best kind of immigrant to the country. In this context, it has been built a series of representations of desirable and undesirable immigrants. At a later time, in the years 1950-1960, the immigration flow continued with the entry of immigrants from Latin American and Asian (Korean and Chinese), who had lower qualification than that desired by the national society and the Brazilian state. The goal of our work is to analyze the positive and negative representations of the immigrant built by Brazilian society and by the state after 1945. We will also aim to investigate how the Brazilian State and Society constructed their own images (be a Brazilian) in the view of the presence of immigrants. Our final goal will be to examine possible forms of prejudice and of intolerance against immigrants in Brazil. The material of our analysis consists of three different discourses (legal, scientific and journalistic). The first type refers to the laws that deal with themes of Brazilian nationality, of the foreign in our country and of the refugee. The second one is considered the scientific discourse, with articles dealing with the selection of immigrants and / or their interaction with the Brazilian Society and State. Last, the third one is selected journalistic discourse, reporting on the contribution of immigrants to the country or their interaction, successful or unsuccessful, with Brazilians. For analysis, we use the semiotics of the French line. Among the various theoretical orientations that semiotics have today, we selected tensile semiotics to explain the formation of the values of speeches dealing with immigration, the socio-semiotic to understand the forms of interaction between immigrants and the Brazilian national society, and the semiotics of passion to understand how emotions and feelings are mobilized in the construction of representations of the immigrant, the national society and the Brazilian State.
\end{abstract}

Keywords: Immigration, History of Brazil since 1945, Representation, Tolerance, Intolerance, French discursive semiotics. 


\section{RÉSUMÉ}

L'immigration au Brésil après 1945 a été caractérisée d'abord par la reprise des groupes d'immigrants plus traditionnels (européens et japonais). Les européens, en général, sont venus travailler dans l'agriculture et / ou dans l'industrie en tant que réfugiés ou personnes déplacées. Avec le retour de ces immigrants, la société nationale et l'Etat brésilien a repris les discussions concernant le meilleur type d'immigrants au pays. Dans ce contexte historique, une série de représentations a été construite des immigrés désirables et indésirables. A un moment plus tard, dans les années 1950-1960, les flux d'immigration s'est poursuivie avec l'entrée des immigrants latino-américains et asiatiques (coréen et chinois), qui avaient une qualification inférieure à celle souhaitée par la société nationale et l'Etat brésilien. Le but de notre travail est d'analyser les représentations positives et négatives de l'immigrant construit par la société et l'Etat brésiliens après 1945. Nous allons aussi voir comment l'Etat brésilien et la société construisent leurs propres images à partir de la présence des immigrés. Notre autre objectif sera d'examiner les formes possibles de préjugé et d'intolérance contre les immigrants au Brésil. Le matériel de notre analyse est composé de trois discours différents (juridique, scientifique et journalistique). Le premier discours concerne les lois qui traitent de thèmes de nationalité brésilienne, des étrangers et des réfugiés dans le pays. Le deuxième type est le discours scientifique, avec des articles traitant de la sélection des immigrants et / ou leur interaction avec la société et l'Etat brésiliens. Le troisième discours est le discours journalistique traitant les rapports sur la contribution des immigrés dans le pays ou de leur interaction avec des Brésiliens. Pour l'analyse, nous utilisons la sémiotique discursive française. Parmi les diverses orientations théoriques que la sémiotique a aujourd'hui, nous avons sélectionné la sémiotique tensive pour expliquer la formation des valeurs de discours portant sur l'immigration, la sociossemiotique pour comprendre les formes d'interaction entre les immigrants et la société brésilienne, et la sémiotique de la passion pour comprendre comment les émotions et les sentiments sont mobilisés dans la construction des représentations de l'immigré, la société nationale et l'Etat brésilien.

Mots-clés: Immigration, Histoire du Brésil après 1945, Représentation, Tolérance, Intolérance, Sémiotique discursive française. 


\section{SUMÁRIO}

Introdução

1. Breve história da imigração no Brasil após 1945

2. Considerações acerca dos conceitos de tolerância e de 47 intolerância

3. Princípios teóricos: elementos para análise da interação entre identidade e alteridade no espaço social brasileiro

4. O discurso jurídico sobre o estrangeiro no Brasil 97
4.1. Preliminares
97
4.2. Sobre a nacionalidade brasileira e sua aquisição
98
4.3. O estatuto do estrangeiro
122
4.4. Estatuto dos refugiados
149
Conclusões do capítulo
167

5. O discurso ‘acadêmico-científico' sobre a imigração e os imigrantes no Brasil: a seleção e a assimilação em foco

5.1. Preliminares

170

5.2. Centralização e totalização em um discurso sobre a imigração no Brasil pós-guerra

173

5.3. Avaliações a respeito do modo de ser dos imigrantes japoneses em um artigo de antropologia

203

5.4. A persistência da noção de raça e de assimilação na década de 1960

Conclusões do capítulo

231

260

6. Notícias sobre a imigração 263

6.1. Preliminares 263

6.2. Construção da imagem positiva do trabalhador imigrante 266 $\begin{array}{ll}\text { japonês: um caso de preconceito linguístico } & 266 \\ \text { A defesa da naturalização: benefícios para o Brasil } & 282\end{array}$

6.3. A defesa da naturalização: benefícios para o Brasil 282

6.4. Tipologia das interações entre estudantes estrangeiros e 302

$\begin{array}{ll}\text { Conclusões do capítulo } & 324\end{array}$

$\begin{array}{ll}\text { Conclusões } & 326\end{array}$

Referências bibliográficas $\quad 333$ 


\section{Introdução}

A identidade nacional brasileira, a partir da segunda metade do século $\mathrm{XX}$, é fortemente marcada pela ideia de democracia racial e pela consequente cordialidade dos brasileiros em relação a diferentes formas da alteridade. Construiu-se assim a imagem de um país formado pela mistura de crenças, de raças e de valores e desprovido de conflitos ou de tensões sociais e culturais.

Muitos discursos já foram produzidos para contestar ou reafirmar esse mito nacional, seja explicitando os confrontos e as explorações sociais, seja para realçar (por vezes com certo ufanismo) os aspectos pacíficos das relações entre brasileiros e dos brasileiros com os que vêm de fora. Um filme recente apresenta bem essas relações entre estrangeiros de diferentes origens com a sociedade brasileira.

Estamos falando do filme $O$ Ano em que meus pais saíram de férias (2006). Nesse filme, as histórias giram em torno da personagem Mauro, apaixonado por futebol, que de forma repentina é deixado pelos seus pais no bairro do Bom Retiro (em São Paulo), sob os cuidados do avô judeu. Seus pais são militantes políticos e precisam se esconder do regime ditatorial em vigência. Nesse bairro, Mauro passa a se relacionar com imigrantes judeus, italianos, gregos e seus descendentes, não sem alguns problemas relacionados, sobretudo, à adaptação às normas e ao estilo de vida da comunidade judaica (apesar de sua origem judaica, Mauro, assim como seus pais, são judeus não praticantes).

Duas frases do filme concentram, em nosso entendimento, toda a ideia da democracia racial. Assistindo a uma partida de futebol amador entre judeus e italianos, Mauro, que naquela cena é narrador do filme, diz que "São Paulo é tão grande que cabe gente de todos os tipos e de todas as torcidas do mundo". Essa frase, situada em um jogo de futebol entre duas comunidades estrangeiras tão diferentes como a judaica e a italiana, nos faz pensar que São Paulo (e por extensão, o Brasil) é o espaço apropriado para o acolhimento de diferentes grupos de origem estrangeira e para a interação entre eles.

Ainda na mesma cena do jogo, ao ver as grandes defesas de Edgar, negro que trabalha em uma lanchonete no mesmo bairro, Mauro crava a seguinte afirmação: "De repente, eu descobri o que queria ser. Queria ser 
negro e voador". O desejo de um garoto de origem judaica de se transformar em um goleiro negro manifesta a ideia de que as diferenças raciais não existem no território brasileiro, ao menos do ponto de vista de uma criança.

Em outro momento significativo do filme, Mauro está jogando bola com seus colegas em um campo improvisado. Ao ver passar um Fusca azul (igual ao de seus pais), Mauro deixa de prestar atenção à partida e toma um gol. Sem entender o que se passava com Mauro, uma das crianças do time adversário diz "Só podia ser judeu" e a confusão entre os dois times se instaura. Alheio a tudo isso, Mauro corre atrás do Fusca azul, na esperança de reencontrar seus pais, mas a decepção logo surge ao aparecer o rosto de um garoto oriental, sentado no banco traseiro do Fusca. Essa cena representa a chegada dos imigrantes asiáticos (chineses e coreanos) a esse bairro. $O$ bairro do Bom Retiro, em nossa leitura do filme, parece realçar (a despeito da confusão no jogo das crianças) as relações de auxílio, de companheirismo e de solidariedade entre diferentes imigrantes e brasileiros que vivem nesse espaço, ligados ainda mais pelo clima nacionalista provocado pela seleção brasileira na Copa do Mundo de 1970. Dessa forma, judeus, italianos, gregos, negros e asiáticos deixam as diferenças em segundo plano para todos se unirem em torno da seleção brasileira de futebol, representante máxima do Brasil no mundo.

Apesar da ideia de unidade nacional, que está acima de todas as diferenças e desavenças, há outro aspecto das relações entre imigrantes e sociedade brasileira (assim como entre os diversos grupos imigrantes), revelado pelo filme e pouco discutido ou realçado nos discursos sobre a imigração no Brasil. Trata-se das relações orientadas por uma imagem negativa do imigrante, produzidas por preconceitos que podem descambar em atos intolerantes e violentos, como vimos acima no exemplo do jogo de futebol entre as crianças.

Nosso trabalho vai analisar a construção das diferentes imagens do imigrante no Brasil, que envolve tanto representações positivas como negativas. O período selecionado para observarmos a construção da imagem do imigrante no país é o que começa em 1945 e chega até os dias atuais. A seguir, apresentaremos traços gerais da história desse período. 


\section{O mundo depois de 1945}

A segunda metade do século $X X$ apresentou uma profunda transformação nos costumes, na política, nos valores e nos hábitos da humanidade ${ }^{1}$.

As décadas que se seguiram ao final da Segunda Guerra Mundial foram marcadas pela independência dos países africanos que estavam sob o julgo do colonialismo europeu, pelo surgimento de novos Estados nacionais, como Israel, e pela criação da ONU (fundada com o objetivo de mediar conflitos entre países e de preservar a dignidade humana por meio dos Direitos Universais do Homem). Com as transformações de Estados, houve também uma série de mudanças nas sociedades. Dentre elas, podemos destacar o fim do campesinato, a universalização do ensino básico e universitário, as lutas pela igualdade de direitos (racial e de gênero), o crescimento do papel feminino no mercado de trabalho, a ascensão da juventude como categoria social e cultural, a revolução sexual, entre outras questões.

Em décadas mais recentes, o processo de globalização e o acelerado avanço tecnológico, levados a cabo pelos países desenvolvidos, têm produzido uma nova transformação das sociedades, diminuindo a distância geográfica e levando a transmissão de informações a uma velocidade nunca vista na história da humanidade. Ao lado do desenvolvimento tecnológico, símbolo de pujança da humanidade, existe a acentuação da miséria dos países subdesenvolvidos. Um dos produtos dessa grande diferença econômica entre países desenvolvidos, em desenvolvimento e subdesenvolvidos foi o aumento do fluxo imigratório. Dessa forma, os países desenvolvidos se tornaram foco de atração de indivíduos que buscam uma vida melhor em outro país. Por exemplo, países como a Itália e a Espanha, que foram anteriormente países de emigrantes, atualmente recebem um grande número de imigrantes em busca de uma vida melhor. Como consequência da presença de imigrantes nos países desenvolvidos, observamos atualmente uma série de mudanças de ordem econômica, religiosa, cultural, social e linguística. É nesse cenário em transformação que os discursos intolerantes e preconceituosos, sobretudo

\footnotetext{
${ }^{1}$ Todas as nossas referências, nessa curta seção, foram encontradas na magistral obra de Eric Hobsbawm (1995).
} 
sobre os imigrantes, retornaram, ao menos no contexto dos países desenvolvidos (Póvoa Neto, 2007: 58-61; Reis, 1999: 136; Reis, 2006: 70-71).

É possível observar, tanto no passado como nos dias atuais, discursos que afirmam ser a imigração um problema para o país porque atribui ao imigrante a imagem generalizada de ameaça aos cidadãos locais. Dessa forma, ressurgem discursos xenófobos, racistas e preconceituosos que propagam temas como os da "invasão estrangeira", o do perigo dos enclaves "étnicos", o da degradação social e cultural do país, o da exploração da assistência social (uso de escolas e hospitais por parte dos imigrantes e seus filhos) e o da responsabilidade dos imigrantes pelo desemprego crescente entre os nacionais. Além disso, ainda existem discussões sobre a possibilidade de integração ou não dos imigrantes aos valores das sociedades receptoras, sendo que muitos grupos estrangeiros não só são considerados de difícil integração como ainda são vistos como de uma cultura completamente incompatível com os valores e práticas nacionais. Essa é o caso, por exemplo, da proibição do uso da burka na França.

A imigração, contudo, não pode ser pensada apenas como um tema concernente aos países desenvolvidos. O Brasil, por exemplo, retomou a imigração depois da Segunda Guerra Mundial e recebeu um considerável número de imigrantes nesse período. Mesmo em um número menor, novos imigrantes continuam a entrar no país em busca de trabalho e de uma melhor condição de vida.

O que acontece, atualmente, nos países desenvolvidos ocorreu e continua a ocorrer no espaço social brasileiro: imigrantes indocumentados, que na maioria das vezes trabalham em condições degradantes, e preconceitos e intolerâncias da sociedade contra o diferente (que podem ser representados por meio de uma desvalorização da cor da pele, da cultura, da religião e da língua, entre outros) estão também presentes no espaço social brasileiro. Mas há também muitas diferenças entre a situação do imigrante no Brasil e a existente nos países desenvolvidos. Não temos, por exemplo, discursos que veiculam, atualmente, a ideia de que o imigrante possa ser uma ameaça ao emprego dos brasileiros, que eles chegam para corromper a cultura nacional, que a intenção deles é a de explorar os benefícios concedidos pelo Estado, etc. Em outras palavras, o medo do imigrante no Brasil é menor do que o existente 
nos chamados países desenvolvidos. Existe, ainda, em muitos casos, uma imagem positiva do imigrante no país, como veremos em nossas análises.

\section{Imigração pós-1945 no Brasil}

O processo imigratório no Brasil pode ser dividido em diferentes etapas, desde seu início no século XIX até os dias atuais.

Nos primeiros momentos da imigração no Brasil, ainda no século XIX, o imigrante foi, basicamente, o trabalhador agrícola. Os imigrantes trabalharam na lavoura como pequenos proprietários, principalmente nos Estados da região Sul do país, ou no cultivo de café, como empregado de grandes fazendas, caminho tomado pela maioria dos imigrantes que vieram para São Paulo. Os imigrantes desse período vieram por meio de empresas de transporte e de colonização e, geralmente, contaram com o auxílio financeiro do seu país de origem ou do Estado brasileiro para realizar a viagem.

Entre o período final da Monarquia e o início da República, uma sociedade constituída em sua totalidade por indivíduos brancos para criar uma "civilização europeia" nos trópicos foi o desejo de uma parcela considerável da sociedade brasileira (constituída por burocratas, intelectuais e cientistas). Esse projeto de branqueamento definiu-se basicamente pela tentativa de transformar a sociedade brasileira em uma sociedade majoritariamente branca com a vinda maciça de imigrantes europeus. Diferentes teorias raciais europeias influenciaram o pensamento brasileiro (sobretudo nas faculdades, como a de Direito e a de Medicina, e nos Institutos Histórico e Geográfico de São Paulo e do Rio de Janeiro) do final do século XIX às primeiras décadas do século XX, em certa medida utilizadas para justificar as propostas do projeto de branqueamento da sociedade. Apesar de serem constituídas por diferentes propostas e correntes de pensamento, houve um traço em comum entre as teorias raciais: o branco, enquanto uma categoria racial, foi considerado muito superior ao negro, ao asiático e ao indígena. Pela sua superioridade, o imigrante europeu branco seria um elemento essencial para alavancar o desenvolvimento econômico, social e racial do país ao mesmo nível das nações civilizadas. 
Após o final da Segunda Guerra Mundial, a entrada de trabalhadores agrícolas estrangeiros foi retomada, pelo menos até meados da década de 1950. No entanto, o Estado brasileiro passou a se interessar por imigrantes europeus com um grau de instrução maior e com conhecimentos técnicos específicos porque o Brasil estava se transformando, naquele momento, em uma nação urbana e industrializada, mas ainda carente de trabalhadores especializados (Freitas, 2001: 51). Contudo, a formação e o conhecimento do trabalhador estrangeiro não foi o único critério utilizado para se selecionar imigrantes para o Brasil. Peres mostra como outro tipo de discurso médico e sanitário substituiu o discurso racial do século XIX, caído em descrédito depois do final da Segunda Guerra Mundial (Peres, 2001: 88-93).

O uso do critério médico e sanitário para seleção de imigrantes esteve presente nos debates entre governo, políticos, intelectuais e cientistas após 1945. Muitas dessas discussões foram travadas na Revista de Imigração e Colonização (daqui por diante denominada RIC), que veiculou discursos com argumentos sanitários (e, implicitamente, raciais) contra determinados grupos imigrantes (Freitas, 2001: 47-48; Peres, 2001: 87-92). Nesses discursos, propunham-se critérios baseados na chamada "ciência moderna". Dentre os critérios propostos, incluíam-se os que pudessem selecionar imigrantes com saúde mental adequada, ausência de problemas políticos e criminais e vontade e força para o trabalho. Consequentemente, esses critérios visaram a impedir a entrada de "psicopatas incubados", "raças estanques", "seres nefastos", "parasitas humanos" etc.

Esses critérios foram utilizados na seleção de novos tipos de imigrantes que surgiram com o final da Segunda Guerra Mundial: os refugiados e os deslocados de guerra (indivíduos e grupos espoliados material e politicamente pela guerra). Além desses novos tipos de imigrantes, o Brasil voltou a receber grupos já conhecidos, como os portugueses, os italianos e os espanhóis. A imigração japonesa, interrompida durante a Segunda Guerra Mundial, foi retomada depois de 1945, apesar da permanência de certo preconceito contra a comunidade nipo-brasileira, como a ideia de inassimilação do imigrante 
japonês, que foi reforçada com os problemas gerados pela Shindô-Renmei (Sakurai, 2004: 11).

Além dos imigrantes japoneses, outros grupos de origem asiática iniciaram sua entrada no Brasil. A primeira leva de imigrantes coreanos chegou ao país no dia 12 de fevereiro de 1963. Essa imigração teve a peculiaridade de ser organizada por civis, membros da Associação Cultural entre Brasil e Coreia (e não por meio de um acordo direto entre os Estados brasileiro e coreano ou mediado por empresas de colonização, como no processo imigratório tradicional) (Choi, 1991: 28). Esses primeiros grupos de imigrantes coreanos saíram de seu país para fugir dos problemas causados pela Guerra da Coreia, assim como dos problemas decorrentes das constantes mudanças políticas pelas quais a Coreia passou quando ainda era um único país. Em décadas mais recentes, segundo Choi, muitos coreanos decidiram deixar seu país por não conseguir ingressar no rígido e concorrido sistema universitário coreano, pois a sociedade coreana ainda estigmatiza os cidadãos que não têm um diploma universitário e, assim, aos que não possuem um diploma de nível superior restam somente os empregos mal remunerados e socialmente pouco valorizados.

Outros grupos de imigrantes passaram a vir para o Brasil, ainda na década de 1950. Imigrantes latino-americanos, sobretudo bolivianos, peruanos e paraguaios, geralmente sem qualquer formação educacional ou profissional ${ }^{3}$, entraram no Brasil em busca de uma vida melhor obtida por meio de trabalhos nas grandes capitais brasileiras.

Boa parte desses novos imigrantes, latino-americanos e asiáticos, chegou para trabalhar no Brasil sem qualquer tipo de qualificação profissional e muitas vezes sem o ensino formal adequado e desejado pela sociedade brasileira. Eles ocuparam (e ainda ocupam) postos de trabalhos e funções menos prestigiados (como os bolivianos que ainda trabalham, em péssimas condições, em oficinas de costura) e até mesmo ilegais (como os chineses e

\footnotetext{
2 Shindô-Renmei (Liga do Caminho dos Súditos) foi uma organização secreta criada por imigrantes japoneses no Brasil após o final da guerra. Os membros dessa organização (conhecidos como "vitoristas") acreditaram na vitória do Japão na Segunda Guerra Mundial e perseguiram, enganaram e assassinaram membros da colônia japonesa que foram contrários a essa ideia (Takeuchi, 2007:76-84).

${ }^{3}$ Uma exceção foi o movimento de imigrantes latino-americanos perseguidos pelos regimes ditatoriais de seus respectivos países, na década de 1970. Esses imigrantes, de um modo geral, possuíam formação universitária (Silva, 2005: 15).
} 
coreanos no chamado "comércio popular"4). Com eles, novos valores, novos problemas e novas línguas vieram se juntar à língua portuguesa e às outras línguas estrangeiras existentes na já heterogênea realidade linguística, social e cultural de alguns dos principais centros urbanos brasileiros.

Da mesma forma que ocorrera com os imigrantes europeus e japoneses, segmentos da sociedade brasileira não viam, e continuam não vendo, essa presença como algo completamente positivo para a sociedade. Essa percepção abre espaço para discursos preconceituosos sobre os valores que esses imigrantes trazem, sobre seu modo de ser e sobre suas respectivas línguas. Veremos, rapidamente, a questão das relações entre a identidade nacional e a alteridade, suas representações e o preconceito e a intolerância existente nessas relações a seguir.

\section{Formas de intolerância e de tolerância: modos de se relacionar com a alteridade}

O mundo conheceu uma das formas mais explícitas de intolerância na Segunda Guerra Mundial. Estamos nos referindo ao holocausto e ao extermínio de milhares de judeus, de ciganos e de indivíduos que não se enquadraram na ideia de "pureza ariana". Essa forma de intolerância foi, claramente, uma política de Estado que visou à eliminação de toda forma de vida que divergisse do padrão imposto pelos governantes alemães. A derrota dos alemães significou o fracasso do antissemitismo e de toda forma de intolerância explicita contra minorias, tal como o racismo (baseado em uma ideia de superioridade da raça branca e a consequente inferioridade dos negros).

Com o final da Segunda Guerra Mundial, diversos países se reuniram para discutir princípios universais que regeriam os direitos de qualquer homem. Dessa reunião, surgiu o que hoje conhecemos como direitos humanos. Essa foi uma das formas encontradas para se combater a intolerância no mundo e para evitar que ela volte com a mesma força. Junto com os direitos humanos, a ética e as leis contra a discriminação reprimem a intolerância e o preconceito, que não possuem mais lugar no espaço público de discussão.

\footnotetext{
${ }^{4}$ Entendemos o "comércio popular" como uma forma de comercialização de produtos de procedência indefinida, a preços mais baixos e em pontos comerciais nem sempre fixos.
} 
No entanto, as intolerâncias e os preconceitos permanecem e, em alguns casos, servem de base para novas formas de exclusão e de violência. Muitas vezes, essas novas formas são sustentadas por justificativas aceitas pela sociedade e utilizadas para não escancarar justamente as formas mais conhecidas e violentas de intolerância e de preconceito. É o caso, por exemplo, em que se afirma que os negros só são bons na dança, na música ou no futebol, deixando implícito que eles não estão aptos para qualquer outra atividade.

Mesmo com o surgimento dessas formas menos agressivas de intolerância, práticas coletivas de discriminação e de extermínio marcaram a segunda metade do século XX. O apartheid na África do Sul, a "limpeza étnica" na Guerra da Bósnia e o neonazismo (presente nas sociedades desenvolvidas, mas como uma minoria) continuam em seu combate contra o outro e contra a diferença, nos fazendo perceber que a intolerância continua a ser um problema central das sociedades contemporâneas.

Entender como a intolerância é expressa nos dias atuais se tornou um tema de interesse não apenas teórico, mas de especial importância social por envolver as condições de existência dos valores culturais e linguísticos de minorias em um fenômeno que ultrapassa as fronteiras nacionais e assume uma escala global, ou seja, que abrange tanto regiões desenvolvidas como regiões em desenvolvimento (certos países da América Latina, do Oriente Médio, da África e da Ásia). Consideramos igualmente importante compreender as formas de tolerância em relação à alteridade, seja para incentivar seu crescimento seja para exigir sua efetiva presença nas relações entre identidade e alteridade. No Brasil, os textos mostram muito bem como ocorrem relações em que as imagens positivas e negativas do imigrante são mobilizadas para uma relação tolerante ou intolerante.

No capítulo referente à intolerância e à tolerância, apresentaremos algumas definições feitas por intelectuais e pesquisadores para, no capítulo teórico, propormos uma "gramática" da intolerância e da tolerância. 


\section{Questões teóricas: os valores, as paixões e a interação nos estudos do discurso}

Como todo objeto de pesquisa, a imigração pode ser analisada a partir de distintas perspectivas teóricas em áreas do saber muito distantes. Muitas páginas já foram produzidas em estudos de Sociologia, Ciência Política, História, Antropologia, entre outras, o que não significa pensar que esse tema já tenha se esgotado. Ao contrário, a imigração está sempre suscitando novas questões que exigem outros olhares dos pesquisadores, obrigando-os a retomar velhos temas e a questionar novos problemas relacionados à imigração. A perspectiva que adotamos para nosso trabalho difere um pouco das áreas acima mencionadas, mas não deixamos de observar o que essas outras áreas já disseram sobre a imigração.

A nossa perspectiva, afinal, é a do discurso e, mais precisamente, a da semiótica de linha francesa, desenvolvida por Greimas e colaboradores, é a teoria utilizada para respaldar nossa análise da organização do discurso intolerante. Nesse ponto de vista teórico, três pontos podem ser considerados essenciais para a formação do discurso intolerante e tolerante: o valor, as paixões e a interação.

Valemo-nos principalmente dos conceitos elaborados nos últimos anos pela semiótica tensiva para tratar da questão do valor no discurso intolerante; no modelo dos regimes de interação elaborado pela sociossemiótica para analisar as formas de relação entre identidade e alteridade; e, por fim, os estados passionais mobilizados na interação são examinados por meio da construção de simulacros da alteridade.

Entendemos que a intolerância e a tolerância, enquanto formas de sociabilidade entre identidade e alteridade, podem mobilizar diferentes paixões (como o medo e o ódio, no caso da intolerância, e a amizade, o amor, a solidariedade e a fraternidade, no caso da tolerância) e valores (os da unidade nacional, social ou cultural, no caso da intolerância, ou os da diversidade, da solidariedade e da universalidade, no caso da tolerância).

A partir desses dois elementos (paixões e valores), a interação entre identidade e alteridade pode ser realizada em termos de um maior distanciamento até a completa exclusão (na intolerância) ou de uma 
proximidade que vai até o completo acolhimento e integração da alteridade (na tolerância). No Brasil, veremos como essas relações tolerantes e intolerantes entre identidade e alteridade são realizadas na interação entre imigrantes, sociedade nacional e Estado brasileiro.

\section{Objetivo principal}

Nosso trabalho objetiva a análise de textos sobre a imigração e sobre o imigrante no Brasil. Os textos tratam de diferentes grupos imigrantes, desde os mais tradicionais (como os europeus e os japoneses) até os grupos mais novos (como os chineses, coreanos e bolivianos) que vieram para o Brasil a partir de 1945. O período histórico contemplado neste trabalho vai de 1945 até os dias atuais e examinará como a sociedade e o Estado brasileiros representam positiva ou negativamente os imigrantes.

\section{Objetivos secundários}

$\mathrm{Na}$ construção da imagem do imigrante, analisaremos as formas de intolerância e de preconceito, mas também os traços positivos da imagem do imigrante. Pretendemos, por fim, examinar a função da língua nos discursos considerados intolerantes e tolerantes em relação aos imigrantes no Brasil.

\section{Material}

Para observar os modos como os discursos sobre a imigração representam (positiva ou negativamente) os imigrantes e o próprio processo imigratório, escolhemos três discursos distintos: o jurídico, o científico e o jornalístico. De um modo geral, por meio desses discursos pretendemos observar: 1) como a imigração e o imigrante (entre outras formas de estrangeiro, como o refugiado) são representados no discurso utilizado pelo Estado para organizar e regulamentar as relações da sociedade; 2) como os discursos acadêmicos tratam da imigração e do imigrante em suas relações com a sociedade brasileira; 3) como o senso comum (a doxa) representa a presença dos imigrantes por meio de notícias de jornal. 
$\mathrm{Na}$ relação entre identidade nacional e alteridade, nos três discursos acima citados, veremos também como se constroem as autoimagens (também positivas ou negativas) da sociedade e do Estado brasileiros.

Em relação às leis, analisaremos a Lei ํo ${ }^{818}$, de 18 de setembro de 1949, que trata da definição da nacionalidade brasileira e dos processos necessários ao pedido de naturalização; a Lei oㅡ 6.815, de 19 de agosto de 1980, que regulamenta a situação e o estatuto jurídicos do estrangeiro no Brasil; e a Lei $n^{0}$ 9.474, de 22 de julho de 1997, que legisla sobre a situação do refugiado no Brasil.

Dos artigos acadêmicos, selecionamos os seguintes textos para análise: a) "A Imigração", de Geraldo de Menezes Côrtes e publicado na Revista de Imigração e Colonização em 1947; b) "O papel das associações juvenis na aculturação dos japoneses", de Ruth Correa Leite Cardoso e publicado na Revista de Antropologia, em 1959; c) "Algumas considerações sobre a imigração no Brasil", de P. Pereira dos Reis e publicado na revista Sociologia em 1961.

No capítulo referente às notícias jornalísticas, os textos selecionados foram: a) "O sol também nasce no Ocidente", publicado na revista $O$ Cruzeiro em 1958; b) "Vale a pena ser brasileiro?", publicado pela revista Realidade em 1966; c) notícias de jornais brasileiros publicados em anos mais recentes ( $O$ Estado de S. Paulo, Folha de S. Paulo e Zero Hora).

\section{Organização da tese}

Nosso trabalho se dividirá em seis capítulos. Desses capítulos, os três primeiros apresentam nosso objeto de pesquisa (a imigração e a intolerância/tolerância) e a concepção teórica que será utilizada para a análise dos três discursos. Os outros três capítulos são reservados a análise dos textos de cada um dos discursos. Segue abaixo um resumo de cada capítulo:

1) Capítulo I: Breve história da imigração no Brasil após 1945 - nesse capítulo, apresentaremos de forma sumária os aspectos gerais da imigração no Brasil pós-guerra, assim como algumas características específicas dos principais grupos imigrantes desse período, na 
tentativa de realçar as diferenças e as continuidades do processo imigratório brasileiro;

2) Capítulo II: Algumas considerações acerca dos conceitos de tolerância e intolerância - retomaremos alguns conceitos de intolerância trabalhados em nossa dissertação de mestrado e aprofundaremos algumas definições desses dois conceitos.

3) Capítulo III: Princípios teóricos - descreveremos em linhas gerais as noções de valor, a partir da semiótica tensiva, de interação, em especial a desenvolvida por Eric Landowski, e das paixões, nos estudos semióticos em geral. Esse capítulo busca formular uma gramática do discurso intolerante e tolerante em torno desses três tópicos teóricos;

4) Capítulo IV: Análise dos discursos jurídicos - esse capítulo analisará as três leis acima mencionadas (a Lei $\mathrm{n}^{\circ}$ 818, de 18 de setembro de 1949; a Lei no 6.815, de 19 de agosto de 1980; e a Lei $n^{0}$ 9.474, de 22 de julho de 1997). As leis serão analisadas com base na análise semiótica do discurso jurídico, além de uma conclusão parcial que comparará diacronicamente as principais características de cada lei;

5) Capítulo V: Análise dos discursos científicos - esse capítulo examinará os três artigos citados anteriormente ( "A Imigração", "O papel das associações juvenis na aculturação dos japoneses" e "Algumas considerações sobre a imigração no Brasil). Apresentaremos alguns elementos característicos desse tipo de discurso, baseados, sobretudo, em Análise do Discurso em Ciências Sociais, organizado por Greimas e Landowski. Uma conclusão parcial retomará os elementos em comum e as diferenças existentes nesses discursos;

6) Capítulo VI: Análise do discurso jornalístico - esse capítulo analisará as notícias acima citadas (O sol também nasce no Ocidente", "Vale a pena ser brasileiro?" e algumas reportagens de jornais brasileiros publicados em anos mais recentes. Com a mesma organização dos capítulos anteriores, serão apresentados alguns traços definidores desse tipo de discurso e uma parte final comparando-os. 


\section{Breve história da imigração no Brasil após 1945}

\subsection{Introdução}

Este capítulo descreve os aspectos mais importantes da imigração pós1945. Antes de entrar propriamente nessa descrição, apontaremos algumas justificativas (apresentadas por dois historiadores e um antropólogo) para os poucos estudos imigratórios desse período.

Além das justificativas para os poucos estudos sobre a imigração no Brasil pós-1945, apresentaremos breve resumo sobre o período anterior da imigração no Brasil, além de alguns fatos associados aos grupos imigrantes que voltaram a entrar no país (japoneses, espanhóis e demais europeus) ou que começaram o movimento imigratório durante o período pós-1945 (principalmente, coreanos, chineses e bolivianos).

\subsection{Imigração no pós-1945: uma história a ser escrita}

O processo imigratório brasileiro é longo e complexo. Ele envolve grupos de diferentes nacionalidades e está repleto de momentos significativos, desde a chegada dos primeiros imigrantes, ainda no século XIX, até os dias atuais. Por isso, é necessário dividi-lo em etapas e periodizá-10 ${ }^{5}$. Historiadores costumam dividir o processo imigratório brasileiro em quatro fases. A primeira, chamada de "grande imigração", iniciou-se em $1870^{6}$ e caracterizou-se pela imigração subsidiada para a lavoura de café e pela colonização na forma de pequenas propriedades, tendo como grupos imigratórios majoritários italianos e

\footnotetext{
5 A periodização é um dos campos mais polêmicos nos estudos historiográficos. Mesmo com essa condição, ela é fundamental para compreender os processos de formação, desenvolvimento e transformação de uma sociedade e de uma nação ao longo do tempo. Além disso, a periodização é essencial para que um fato ou um acontecimento se torne inteligível ao entendimento humano. Este capítulo não tem a intenção de entrar nessa longa e arenosa polêmica, mas apenas indicar uma possível (dentre outras igualmente válidas) organização histórica do processo imigratório brasileiro. A palavra será, então, passada aos que de fato e de direito podem versar sobre o processo histórico com muito mais propriedade.

${ }^{6}$ Manuel Diégues Jr divide a história da imigração em três fases: a primeira, de 1808 a 1850; a segunda, de 1850 a 1888; e a terceira, de 1888 a 1950. Entendemos que a ausência da menção ao primeiro período no texto de Oliveira (2008), usado em nosso trabalho como referência para a periodização da imigração no Brasil, se deve aos poucos imigrantes que entraram no país nesse período. Como o próprio Diégues afirma: "No primeiro período, aqui considerado - o que vai de 1808, ou mais precisamente 1819, até 1850 - o volume de imigração foi pequeno; expressou-se por um total de apenas 21.599 pessoas" (Diégues Jr., 1964: 38).
} 
alemães, principalmente no período de 1886 a 1902. A segunda fase, compreendida entre os anos de 1906 e 1914 (às vésperas da Primeira Guerra Mundial), contou com um aumento da entrada de imigrantes espanhóis e portugueses (que começaram a chegar ao país no século XIX, ainda em pequena escala), além do início da imigração japonesa (em 1908). A terceira fase, de 1918 a 1945, definiu-se pela retomada da imigração portuguesa, pelo aumento da entrada de japoneses e pela vinda de outros grupos, como poloneses, russos e romenos (Oliveira, 2006: 8-9) ${ }^{7}$.

A quarta fase teve início após o final da Segunda Guerra Mundial e continua até os dias atuais. Mesmo sendo a fase mais longa entre as quatro fases da imigração no Brasil, esse período foi e continua sendo pouco estudado pela historiografia brasileira, assim como pela antropologia e pela sociologia nacionais. Três pesquisadores (dois historiadores e um antropólogo) apresentam algumas razões para a ausência de estudos sobre o processo imigratório depois de 1945.

Jeffrey Lesser, historiador norte-americano, diz que os estudos sobre etnia e raça - temas frequentemente associados à imigração - foram substituídos por pesquisa sobre as relações de classe social (uma vez que o conceito de classe englobaria, para esses estudos, as noções de etnia e de raça). Em uma clara guinada marxista dos estudos historiográficos, o foco passou a ser o estudo das classes excluídas e exploradas pela elite dominante brasileira. Lesser refere-se ainda ao fato de a historiografia nacional ter-se concentrado nas questões políticas da ditadura militar ${ }^{8}$, deixando de lado 0 estudo das relações étnicas ${ }^{9}$ no Brasil (Lesser, 2008: 57-58).

\footnotetext{
7 As três primeiras fases da imigração no Brasil apresentam um considerável conjunto de estudos realizados. O mesmo não pode ser dito para a quarta fase. Ainda não existem estudos sistematizados e, por conseguinte, completos sobre essa fase da história da imigração no Brasil.

${ }^{8}$ Em um de seus trabalhos (Uma Diáspora Descontente), Lesser (2008) apresenta as relações que os descendentes de imigrantes japoneses mantiveram com a sociedade brasileira durante esse período. Seus estudos mostram, assim, que os descendentes muitas vezes utilizavam a representação étnica como uma estratégia de combate à ditadura. Esse foi o caso, dentre outros, de André Massafumi Yoshinaga e de Shizuo Osawa, o "Mário Japa", que se aproveitavam da boa imagem dos japoneses e de seus descendentes na sociedade brasileira para realizar ousadas ações contra os militares.

9 Os trabalhos de Lesser se baseiam em um interessante conceito conhecido como "identidade hifenizada". Basicamente, esse conceito define a identidade como uma representação fluída, no sentido de se modificar conforme as necessidades do contexto, das vontades das minorias sociais ou ainda da força da representação dos imigrantes e de seus descendentes construída pela sociedade brasileira. Dessa forma, o autor compreende as relações entre as minorias e a sociedade brasileira em termos de uma constante negociação de identidades.
} 
Para a historiadora Célia Sakurai, os especialistas concentraram-se nos seguintes temas: os desequilíbrios econômicos mundiais, a democracia (ou sua ausência) nos países pós-guerra e a Guerra Fria (2008: 190). No contexto histórico brasileiro, ela vai ao encontro das razões apontadas por Lesser: o predomínio de temas como a ditadura militar, assim como de suas consequências sociais e políticas presentes até os dias atuais, explicaria (mas não justificaria) a falta de trabalhos a respeito da imigração no Brasil durante esse período.

O antropólogo João Baptista Borges Pereira indica outros elementos para explicar os poucos estudos brasileiros sobre a imigração pós-1945. Para ele, há três fatores para essa ausência. O primeiro está relacionado à ideia generalizada de que a imigração é "coisa do passado" e, por isso, não teria mais qualquer ligação com as relações sociais atuais. Para o autor, essa ideia está ainda atrelada à percepção de que o fluxo imigratório pós-1945 sofreu forte diminuição. O predomínio do conceito de "democracia racial" é apontado como o segundo fator para essa ausência de estudos sobre a imigração desse período. O conceito de "democracia racial"10, segundo o autor, serviu, e ainda serve, para "abafar" a diversidade cultural e étnica presente na sociedade brasileira e, consequentemente, as tensões e os conflitos que daí poderiam surgir com a presença dos imigrantes. Em outras palavras, a "democracia racial" serviria para passar a sensação de que o país não possui qualquer tipo de problema em relação à presença de imigrantes e estrangeiros. Logo, não haveria necessidade de estudar ou de pesquisar esse tema nas universidades. E, por último, o terceiro fator, mais específico da área de antropologia, é o do crescente desprestígio dos estudos sobre "aculturação"11 que estavam, em seus primórdios, associados ao tema da imigração no Brasil (Pereira, 1992: 159-160).

Esses três autores apontam alguns elementos em comum, assim como características específicas para explicar a marginalização dos estudos sobre a imigração no período subsequente a 1945. De qualquer forma, eles compartilham um ponto de vista em comum: a história da imigração no Brasil

\footnotetext{
${ }^{10}$ De modo superficial, o conceito de "democracia racial" pode ser entendido como uma representação de relações sociais desprovidas de preconceito e de discriminação racial no Brasil (Guimarães, 2004).

${ }^{11}$ Basicamente, a aculturação é um conceito sociológico que se refere à transformação dos padrões culturais de um ou dos dois grupos sociais em contato (Cuche, 2002: 115-116).
} 
pós-1945 ainda está por ser feita. Isso, contudo, não significa que os estudos sobre a imigração pós-1945 não existam. Trabalhos espalhados em artigos, teses ou dissertações sobre determinados grupos foram e continuam sendo realizados, tanto que esses estudos possibilitaram a feitura deste capítulo. $\mathrm{O}$ problema é que não há ainda um trabalho de referência que sintetize as grandes características da imigração desse momento histórico, associadas aos traços mais importantes da história brasileira e mundial.

Antes de descrevermos as características da imigração no Brasil pós1945, apresentaremos, a seguir, um resumo da história mais conhecida da imigração, ocorrida entre os anos de 1870 a 1945.

\subsection{Resumo da imigração no Brasil até 1945}

A colonização, a pequena propriedade e o projeto de "branqueamento" da sociedade nacional são as características que melhor definem o processo imigratório brasileiro iniciado no século XIX e que perdurou até meados do século XX (aproximadamente até o final da Segunda Guerra Mundial). A imigração envolve, assim, uma dimensão econômica (com a colonização e a pequena propriedade) e uma dimensão sociocultural (com as contribuições sociais e culturais que eles poderiam oferecer ao Brasil). Em ambas as dimensões, a sociedade e o Estado brasileiros construíram uma imagem positiva de determinados grupos imigrantes e uma representação negativa de outros grupos imigrantes.

No final do século XIX, com a presença maciça de africanos escravos, surgiu a ideia de que a sociedade brasileira se tornaria mais fraca na medida em que a presença de indivíduos brancos diminuísse. Nesse mesmo período, a formação da identidade nacional brasileira foi uma das principais preocupações de parte da sociedade brasileira. Assim, uma série de propostas foi pensada para tornar a sociedade brasileira eminentemente branca e não mais mestiça, como fora considerada na época pelas "elites pensantes"12. A solução proposta para resolver o "problema" da composição da sociedade brasileira foi,

\footnotetext{
${ }^{12}$ A mestiçagem foi muito mal vista pela sociedade brasileira de então porque se imaginou que a mistura de brancos com outros grupos conduziria o país a uma degeneração social com o enfraquecimento da presença de "brancos puros". Somente após o surgimento da ideia de "democracia racial" é que a imagem de um país mestiço passou a ser valorizada.
} 
justamente, aumentar o número de imigrantes europeus no país. Essa proposta teve como base a crença em uma suposta superioridade da raça branca em relação às raças amarela e, especialmente, negra ${ }^{13}$ (Skidmore, 1976: 81-96; Seyferth, 1990: 18). Visou-se, em seu limite, à fundação de uma civilização europeia nos trópicos, baseada na suposta superioridade racial dos brancos, que seria responsável por colocar o Brasil no mesmo nível de desenvolvimento dos países mais avançados do mundo naquele momento.

A seleção de imigrantes brancos foi, então, considerada fundamental para o desenvolvimento econômico, a formação cultural nacional e a constituição racial da sociedade brasileira. $O$ projeto de branqueamento envolveu essas três questões, pois os imigrantes brancos e europeus foram considerados elementos fundamentais para o desenvolvimento econômico nacional (com seu conhecimento e sua força aplicados no desenvolvimento do trabalho agrícola), para a sedimentação da alta cultura europeia nos trópicos (desejo da "elite letrada" mais próxima dessa cultura por sua formação) e para constituir uma sociedade eminentemente branca, excluindo assim o negro e o mestiço (que impediriam o Brasil de alcançar a condição de uma nação desenvolvida). Contudo, o projeto de branqueamento não foi um consenso quando se tratou de discutir o tema da imigração no Brasil, porque parte da elite governamental e intelectual considerou positiva a entrada de imigrantes que não fossem de origem europeia.

De qualquer forma, a vertente favorável à entrada de imigrantes de origem europeia e, principalmente, os de origem latina predominou nessas discussões (ao menos até os primeiros anos do século XX). Assim, espanhóis, portugueses e italianos foram, segundo Oliveira (2001: 10), os imigrantes almejados por serem brancos e por causa da proximidade da língua (neolatina), da religião (cristã) e da cultura (ibérica ou mediterrânea).

As discussões sobre a política imigratória mobilizaram ainda outra questão, além da seleção de imigrantes com as características desejadas por parte da sociedade brasileira: a assimilação dos imigrantes. O raciocínio por trás da assimilação foi bastante simples: a fixação definitiva de grupos

\footnotetext{
${ }^{13} \mathrm{O}$ projeto de branqueamento da sociedade brasileira atingiu diretamente as tentativas de início da imigração asiática no país e a efetiva integração social do negro na sociedade brasileira.
} 
imigrantes previamente selecionados poderia melhorar a sociedade nacional por meio de uma posterior mistura entre imigrantes e brasileiros.

Em relação ao aspecto econômico da imigração, houve dois tipos com finalidades distintas. O primeiro tipo foi a imigração destinada à pequena propriedade, em regime de terras devolutas, cujo início ocorreu durante o período Joanino (a partir de 1808) e continuou até as primeiras décadas do século XX. Os objetivos desse primeiro tipo de imigração foram o de colonizar terras ocupadas por índios ou em regiões fronteiriças. Grande parte desse tipo de ocupação ocorreu na região Sul do país e, em especial, no Rio Grande do $\mathrm{Sul}^{14}$.

O segundo tipo de imigração teve por objetivo a complementação de mão-de-obra para o latifúndio cafeicultor, principalmente no estado de São Paulo, antes mesmo da abolição da escravatura. Nessa forma de imigração, são vários os exemplos de imigrantes bem sucedidos porque parte considerável desses trabalhadores conseguiu se tornar proprietário de terras. Contudo, esse tipo de imigração não deixou de apresentar alguns problemas, como a baixa remuneração salarial do trabalho nos cafezais e as precárias condições de moradia e de alimentação, que geraram uma série de descontentamentos nos imigrantes. Muitos se sentiram, com razão, lesados e enganados pelos proprietários de fazendas e pelas empresas de colonização, porque pouco do que tinha sido estabelecido em contrato foi cumprido. Por isso, muitos fugiram das fazendas de café ou para se instalar nas cidades ou para retornar ao seu país de origem. Mesmo com condições precárias de trabalho e moradia no Brasil, muitos dos imigrantes permaneceram no país e construíram uma história bem sucedida. As características acima descritas permaneceram as mesmas, de um modo geral, até meados da Era Vargas, quando as relações entre os imigrantes e a sociedade e o Estado brasileiros foram radicalmente transformadas e um clima de perseguição contra os imigrantes se instalou no país.

O governo Vargas, em decorrência da Segunda Guerra Mundial, aplicou uma série de políticas restritivas aos imigrantes japoneses, alemães e italianos

\footnotetext{
${ }^{14}$ Outra característica marcante desse período da imigração no Brasil estava na considerável presença de empresas colonizadoras e de transporte que se encarregavam de lotear as terras para a vinda dos imigrantes e se responsabilizavam também pelo seu transporte (Petrone, 1982: 119).
} 
presentes no Brasil e limitou a entrada de novos imigrantes, antes mesmo de declarar guerra contra os países do Eixo. Com isso, os imigrantes encontraram-se em uma situação inusitada, pois sua presença gerou desconfiança por parte da sociedade e do Estado brasileiros e, ao mesmo tempo, não tinham condições ou possibilidade de sair do Brasil e retornar aos seus respectivos países de origem.

As restrições do governo brasileiro criaram aos imigrantes um ambiente de maior controle sobre seus comportamentos e sobre o uso de sua língua de origem, principalmente no espaço público. Um dos fatos mais importantes das políticas restritivas foi o processo de "nacionalização do ensino", ou seja, a obrigatoriedade do ensino de língua portuguesa, da história e da geografia brasileira e o fechamento de escolas de comunidades estrangeiras (principalmente alemã, italiana e japonesa) que não seguiram essa ordem ${ }^{15}$. A situação de fiscalização e de controle só foi alterada após o final da Segunda Guerra Mundial, quando ocorreu também o fim das chamadas grandes imigrações sob a chancela do Estado e das empresas colonizadoras.

Com o término da Segunda Guerra Mundial, o clima de perseguição aos imigrantes dos países do Eixo foi amenizado e o processo imigratório foi retomado. Nesse contexto pós-guerra, inúmeros europeus, vítimas da guerra que devastou seus países, viram-se obrigados a procurar novas oportunidades em outros países, entre eles, o Brasil.

\subsection{Linhas gerais da retomada da imigração no Brasil depois de 1945}

O dia 18 de setembro de 1945 é considerado a data oficial de retomada da imigração no Brasil. Nesse dia, ainda no Estado Novo de Getúlio Vargas, foi publicado o Decreto-Lei no. 7.967, que retomou a imigração. Nesse momento, foi mantido o sistema de cotas anteriormente estabelecido em $1934^{16}$ (Salles, 2004: 3).

\footnotetext{
15 O documentário "Sem Palavras" (2009) retrata bem esse momento de perseguição aos imigrantes alemães no Brasil ao apresentar depoimentos de imigrantes e de seus descendentes que viveram a situação de não poder falar alemão na rua nem na escola, como um subsídio para o aprendizado do português, entre outras situações.

${ }^{16} \mathrm{O}$ sistema de cotas limitou a $2 \%$ o número de entrada de novos imigrantes para cada nacionalidade que chegou ao país nos últimos 50 anos.
} 
Os imigrantes desse período fugiram da Europa principalmente por causa dos horrores causados pela guerra. Parte desses imigrantes foi formada por agricultores, mas outra parte foi constituída por indivíduos com um grau de instrução maior: "Eram camponeses, operários, técnicos, profissionais liberais, intelectuais" (Freitas, 2001: 46).

Uma diferença substancial, em relação ao processo imigratório anterior (que pode ser definido como uma imigração dirigida ${ }^{17}$ ), está no fato de que os imigrantes que vieram para o trabalho na agricultura foram, em sua maioria, os deslocados de guerra e os refugiados. Esses indivíduos foram encaminhados ao Brasil por comitês de apoio internacionais, como o Comitê Internacional para as Migrações Europeias (CIME), a Comissão Católica de Migrações e a Organização Internacional para os Refugiados (OIR) ${ }^{18}$ (Salles, 2004: 4; Freitas, 2001: 48-50).

Os deslocados de guerra foram definidos como indivíduos arrancados à força de seus respectivos países. Os refugiados, por sua vez, foram vistos como indivíduos que saíram espontaneamente de seus países, o que, como ressalva Peres, é um conceito impreciso, pois esse tipo de imigrante saiu de seu país por necessidade (em decorrência de perseguições, por exemplo) e nunca como opção. De qualquer forma, os refugiados foram representados na Revista de Imigração e Colonização (doravante RIC) como elementos ideologicamente mais perigosos do que os deslocados de guerra e, por isso, mais frequentemente rejeitados pelo governo (Peres, 2003: 86-87).

Os poloneses formaram o principal grupo entre um total de 1.700 .000 considerados como deslocado de guerra ou refugiado que permaneceram em solo alemão ou austríaco depois da guerra. Segundo Salles, o grupo de deslocados de guerra foi composto da seguinte maneira:

(...) os poloneses representam a etnia mais numerosa, quase $29 \%$ do total, seguida pelos ucranianos $(12,3 \%)$, baltas $(9 \%)$, húngaros $(7,8 \%)$ e russos (7,6\%). Em seguida, aparecem os iugoslavos $(7 \%)$, os tchecos $(2,4 \%)$ e várias nacionalidades que, reunidas, perfazem mais de $15 \%$, seguidas pelos classificados como apátridas, porque haviam perdido a nacionalidade. As "outras nacionalidades" são formadas por: alemães (8,5\%), austríacos (3,5\%), armênios $(0,7 \%)$, búlgaros $(0,4 \%)$, gregos $(0,18 \%)$, "brasileiros" $(0,17 \%)$, albaneses $(0,02 \%)$, espanhóis $(0,06 \%)$, franceses $(0,06 \%)$, holandeses

\footnotetext{
${ }_{17}$ A imigração dirigida é aquela que envolve a participação de Estados e de companhias de transporte.

${ }^{18}$ A Organização Internacional para os Refugiados foi substituída pela criação do Alto Comissariado das Nações Unidas para Refugiados (ACNUR) em 1951.
} 
$(0,02 \%)$, italianos $(0,12 \%)$, norte-americanos $(0,02 \%)$, romenos $(1,6 \%)$, suíços $(0,01 \%)$ e turcos $(0,02 \%)$ (Salles, 2004: 13).

Parte dos novos imigrantes que entraram no Brasil foi formada por deslocados de guerra e, em menor quantidade, por refugiados. Mas outra parcela desses novos imigrantes foi constituída por indivíduos que não tiveram qualquer tipo de ajuda governamental. Esses vieram para trabalhar ou na agricultura ou na indústria nacional e entraram no país por meio das "cartas de chamada" de parentes que já viviam no país (a chamada imigração espontânea) (Oliveira, 2006: 9; Peres, 2003: 34). Como mostra Peres, era uma prática muito comum às famílias imigrantes já estabelecidas no Brasil enviar cartas para os parentes, facilitando, assim, a vinda e a entrada desses novos imigrantes. A facilidade esteve, de um lado, localizada nas informações transmitidas aos novos possíveis imigrantes e, de outro lado, na ideia de que eles teriam suporte material e sentimental das famílias já estabelecidas, diminuindo a possibilidade de fracasso ou de retorno.

Ainda segundo Salles, por volta de 11.000 deslocados de guerra chegaram entre 1947 e 1952 ao Brasil, direcionados principalmente para a cidade de São Paulo. Se forem ainda incluídos os imigrantes que chegaram por meio das "cartas de chamada", a partir de 1945, foram mais de 300.000 imigrantes a entrar no país nesse período. Segundo levantamento feito por essa autora, eles se dividiram em "11 216 agricultores, 67319 operários em geral, 6280 qualificados, 4535 técnicos, 134806 domésticos, além de 89402 não especificados" (Salles, 2004: 12).

Como consequência desse novo movimento imigratório, a sociedade brasileira retomou as discussões sobre o melhor tipo de imigrante que o país deveria receber. Houve, ainda, um deslocamento da imagem do imigrante que o país almejava. O interesse brasileiro progressivamente deixou de ser por trabalhadores direcionados às lavouras e passou a ser por trabalhadores com formação técnica que pudessem contribuir com o desenvolvimento e 0 estabelecimento do parque industrial nascente:

$\mathrm{Na}$ imigração após a Segunda Guerra, houve decréscimo de entrada de agricultores e crescimento de grupos profissionais constituídos de operários qualificados e os técnicos. Esta tendência acompanha a evolução de um país 
essencialmente agrícola que se transformava em um país industrial e urbano (Freitas, 2001: 51).

O parque industrial crescente, em especial no Estado de São Paulo, criou a imagem de um país que finalmente encontrou o caminho do desenvolvimento econômico pleno, mas ainda com uma grande carência de mão-de-obra especializada, cuja supressão seria realizada com a vinda de novos imigrantes (Peres, 2003: 62). Assim, os imigrantes continuaram a ter um papel central nas discussões a respeito do desenvolvimento econômico nacional, como já ocorrera no século XIX e nas primeiras décadas do século $X X$.

Um bom exemplo sobre as profissões mais requisitadas pelo governo brasileiro pode ser encontrado no Relatório da Repartição Internacional do Trabalho/Brasil, que, em 1953, indicou os seguintes profissionais para o país: engenheiros, técnicos e trabalhadores qualificados nas indústrias têxteis, químicas e manufatureiras de ferro e aço, mecânicos (de rádio e automóveis), torneiros, eletricistas, ajustadores, trabalhadores qualificados em engenharia, carpinteiros, pedreiros, e trabalhadores de construção em geral, estofadores, alfaiates, governantas (professoras) e nurses, criadas e trabalhadores agrícolas (Freitas, 2001: 52). Foram excluídos dessa lista os profissionais liberais, como médicos, dentistas, advogados, arquitetos, contabilistas, acadêmicos, professores etc. Isso ocorreu, porque se acreditou que eles teriam problemas com o uso da língua portuguesa e, por essa razão, precisariam fazer exames para revalidar seus diplomas ${ }^{19}$. Além disso, houve a preocupação de não se trazer imigrantes que pudessem competir diretamente com os brasileiros (restrição já prevista, inclusive, no artigo 150 da Constituição de 1937) (Freitas, 2001: 52).

O país necessitava, naquele momento, de imigrantes qualificados para a indústria. Mas esses imigrantes não poderiam se desviar de um determinado padrão comportamental, físico e cultural almejado pela sociedade brasileira. Repetir-se-iam, assim, determinados traços da política imigratória da Era Vargas (Peres, 2003: 86), que visou, sobretudo, a imigrantes de origem

\footnotetext{
${ }^{19}$ Por meio desse exemplo, é possível observar que a questão linguística também foi utilizada como um critério para selecionar os imigrantes que interessavam diretamente ao país naquele momento.
} 
europeia em detrimento das demais nacionalidades, principalmente dos asiáticos $^{20}$.

Para serem aceitos no país, todos os imigrantes deveriam cumprir determinados critérios estabelecidos pelo governo brasileiro, como qualidades físicas, mentais, profissionais, ideológicas e raciais. Os artigos publicados na RIC defenderam o uso de critérios médicos para seleção dos imigrantes que pudessem entrar no país, em especial os deslocados de guerra. Esses textos ainda criaram determinadas imagens dos imigrantes indesejados, que foram relacionadas, principalmente, a problemas psicológicos decorrentes da guerra (Peres, 2003: 87-89). A título de exemplo, reproduzimos um trecho do texto de Antonio Xavier de Oliveira, publicado na RIC em 1946:

(...) com cândida bondade e responsável inocência espécimes degenerados de raças indesejáveis, velhos e crianças inúteis para o trabalho produtivo, e tudo isso com a cumplicidade de um governo de homens cultos e patriotas, mas que, embora estadistas, desconhecem as conquistas da ciência moderna e não ouvem os conselhos dos seus cultores maiores. Se assim não fora, certo que não continuaríamos a receber os rebutalhos humanos, a escória de raças miseráveis, proxenetas de todas as procedências, para incorporar à nossa nacionalidade, num atentado, num crime de lesa-pátria, que não afeta só o Brasil, mas também (...), toda a América (Oliveira apud Peres, 2003: 90).

O discurso médico/biológico camuflou uma preocupação relativa à constituição racial da sociedade brasileira. Dessa forma, foram encontradas, nesses discursos, palavras explícitas favoráveis ao homem branco europeu (com a preferência, apontada anteriormente, por imigrantes de origem latina, como portugueses, espanhóis e italianos), que o indicaram como o melhor tipo de imigrante para o país, ao mesmo tempo em que condenaram a entrada de judeus e de japoneses, tal como ocorrera no período anterior da imigração (Peres, 2003: 93). Em resumo, algumas características dos imigrantes continuaram em pauta pela sociedade e pelo Estado brasileiros, como indica Peres:

\footnotetext{
${ }^{20}$ Veremos, na última seção deste capítulo, como o interesse do governo brasileiro se voltou para a entrada de imigrantes europeus (na condição de refugiados) quando instituiu a reserva geográfica para o recebimento dos refugiados. Dessa forma, o governo brasileiro decidiu que só receberia refugiados vindos da Europa.
} 
Buscava-se um Brasil moderno, onde não haveria espaço para o imigrante não qualificado ou para aquele que não fosse portador de um comportamento visto como 'normal' e de uma constituição física e genética considerada 'ideal', como também desprezava-se muitas vezes o trabalhador nacional, tido como indolente (Peres, 2003: 34).

A sociedade e o Estado brasileiros pensaram que, com o fim da Segunda Guerra Mundial, aquele seria o momento de transformar o Brasil em grande potência econômica. Para atingir esse objetivo, o país deveria explorar as potencialidades de sua natureza, estabelecer um parque industrial consistente e, ainda, prosseguir com o processo, já em andamento, de "branqueamento" da sociedade por meio da mestiçagem. Os imigrantes europeus viriam, assim, para auxiliar o país a se desenvolver economicamente e para acelerar o processo de "branqueamento" da sociedade brasileira (Peres, 2003: 60). O processo de "branqueamento" foi, então, considerado um dos pilares do desenvolvimento do país.

A miscigenação defendida pelos autores que escreveram na RIC teve, em seu limite, a ideia de que os imigrantes europeus selecionados com base em critérios eugênicos e raciais formariam a base social do país. Ao mesmo tempo, os considerados "maus brasileiros" (negros e índios, trabalhadores "indolentes" e pobres) seriam, com o passar do tempo, eliminados da sociedade brasileira:

A política imigratória transformara-se, portanto, em garantia para um futuro promissor. O Brasil deveria posicionar-se como avesso ao 'estranho' buscando a homogeneidade racial que, por sua vez, sustentaria a Nação que se formava. A ciência atrelada ao Estado seria a responsável pela criação do 'novo' Brasil, livre dos entraves representados pelos 'maus elementos' que vinham de fora, mas também pela permanência de uma população nativa fraca e doente. $A$ solução proposta era a seleção eugênica e racial dos imigrantes e o abandono das populações carentes a sua própria sorte, levando-as à extinção (Peres, 2003: 98).

Além de se recorrer a critérios considerados científicos, os artigos da RIC também criaram a imagem de um país racialmente democrático e tolerante, a despeito da clara preferência por imigrantes brancos em todos os textos que propuseram critérios de seleção dos imigrantes. Contrariamente a essa imagem de tolerância e de respeito à diversidade, procurou-se ainda inculcar os valores nacionais, por meio do ensino da língua, da história e da 
geografia, nesses novos imigrantes, tal como já havia sido formulado durante a Era Vargas (Peres, 2003: 96).

Outra característica que permaneceu nas discussões sobre a imigração no Brasil nesse período foi a questão da integração dos imigrantes à sociedade brasileira. Consequentemente, as preferências e as discussões envolveram também o tema da assimilação. Por isso, a imagem do imigrante que viria com o intuito de apenas enriquecer para depois retornar à sua pátria foi completamente rejeitada. O medo dos "quistos étnicos" também permaneceu, mesmo após o final da guerra, e a sociedade brasileira voltou a discutir maneiras de evitar esse "perigo", principalmente em relação aos alemães, aos japoneses e aos judeus (Peres, 2003: 95-96).

Vimos, nesta seção, as características gerais da retomada do processo imigratório no Brasil depois de 1945. Veremos, a seguir, alguns traços principais do retorno dos grupos imigrantes mais tradicionais desse período.

\section{5. $O$ retorno dos grupos imigrantes tradicionais na imigração pós-guerra no Brasil}

Nesta seção, serão apresentados alguns traços dos grupos imigrantes mais conhecidos do processo brasileiro, como espanhóis e japoneses, que voltaram a entrar no Brasil após o final da Segunda Guerra Mundial.

Oficialmente, a imigração japonesa no Brasil só foi retomada com o Decreto-Lei n ${ }^{0}$. 52.920, assinado pelo então presidente João Goulart em 1963. Na prática, a imigração japonesa no Brasil foi retomada em 1953, um ano depois do restabelecimento das relações diplomáticas entre Brasil e Japão. Ainda assim, os imigrantes japoneses que chegaram em janeiro daquele ano só puderam entrar no país, porque possuíam "cartas de chamada" de parentes que já residiam no Brasil (Takeuchi, 2007: 88-89; Sakurai, 2008: 211). O período entre 1952 e final da década de 1970, quando 46.000 japoneses entraram e se estabeleceram no Brasil, é considerado a terceira e última fase da imigração japonesa em massa para o Brasil (Suzuki, 1995: 58).

Em 1952, chegou um grupo que foi chamado por meio das "cartas de chamada" e que ficou conhecido como "jovens imigrantes de Cotia". Esses imigrantes vieram por causa da necessidade da CAC (Cooperativa Agrícola de 
Cotia) em formar novos quadros técnicos para dar continuidade aos trabalhos agrícolas da cooperativa (naquele momento em franca expansão no interior paulista). Como o número de imigrantes que chegaram em 1952 por meio das "cartas de chamada" foi pequeno, a CAC solicitou autorização ao governo brasileiro para trazer 500 lavradores por ano. Com autorização aprovada pelo Instituto Nacional de Imigração e Colonização, a cooperativa formou 1.500 técnicos entre os anos de 1955 e 1958 e conseguiu nova autorização para formar mais 1.500 técnicos. A última turma de imigrantes foi formada nessas condições em 1967 (Takeuchi, 90-91).

Dois empresários japoneses (Kotaro Tsuji e Tasutaro Matsubara), já instalados no Brasil, foram autorizados pelo governo, também em 1952, a trazer por volta de 4 a 5 mil imigrantes japoneses. Assim, a imigração em massa foi retomada, e os primeiros grupos chegaram em fevereiro de 1953, com suas despesas arcadas pelo próprio governo japonês. Esses dois empresários japoneses trouxeram trabalhadores imigrantes para o Brasil até 1961 e os enviaram para estados como Amazonas, Mato Grosso do Sul, Bahia e Minas Gerais (Takeuchi, 2007: 89).

Os novos imigrantes japoneses encontraram as mesmas dificuldades dos primeiros imigrantes nipônicos que chegaram nas décadas iniciais do século XX no Brasil. Nas palavras de Takeuchi, essas dificuldades caracterizaram-se por

[...] fugas e atritos motivados pelo desconhecimento das condições de vida naquelas regiões, pelas diferenças de usos e costumes e, finalmente, pela disparidade do nível cultural em relação à maioria dos moradores locais. Como nos primeiros tempos da imigração japonesa no Brasil, houve falta de preparo e de planejamento no recebimento desses imigrantes (2007: 90).

Outro grupo de imigrantes japoneses chegou ao Brasil por intermédio de Ryota Nagasawa, funcionário do Ministério da Construção do Japão. Constituído por jovens japoneses, esse grupo foi treinado no Japão, na área de desenvolvimento industrial. Eles receberam também um segundo treinamento técnico no Brasil para que pudessem partir para outras áreas de trabalho que não fossem aquelas para as quais eles haviam se formado. Esse outro treinamento foi ministrado no Paraná para diversas turmas entre os anos de 1958 e 1965 (Takeuchi, 2007: 91-92). 
Mesmo com o retorno da imigração japonesa no Brasil, a comunidade nipônica continuou a ser vista com uma forte desconfiança por parte da sociedade brasileira. Além disso, fatos ainda relacionados à Segunda Guerra Mundial, como o fenômeno Shindô-Renme21 ${ }^{21}$ contribuíram para o aumento da imagem negativa da comunidade em sua relação com a sociedade e com o Estado brasileiros. Segundo Sakurai, os problemas gerados pela ShindôRenmei apenas reforçaram uma imagem negativa da comunidade nipônica no Brasil, como se ela fosse composta somente por indivíduos fanáticos e de difícil assimilação (Sakurai, 2008: 211).

Um dos reflexos dessa imagem negativa da comunidade japonesa por parte da sociedade brasileira apareceu na emenda número 3165, proposta por Miguel Couto Filho (filho de Miguel Couto, outro político famoso por ser contrário à presença de imigrantes japoneses no país) durante a Constituinte de 1946. Essa emenda propôs medidas antinipônicas e sua votação foi marcada por um empate, só definido pelo voto de minerva dado pelo presidente da Constituinte, Fernando Mello Viana (do Partido Social Democrático mineiro), que se colocou contra a aprovação da emenda. A emenda contou também com o apoio do Partido Comunista Brasileiro, liderado por Carlos Prestes, naquele momento (Takeuchi, 2007: 85-86) 22. $^{22}$

Além da imagem negativa da colônia japonesa permanecer por alguns anos, a entrada de novos imigrantes japoneses apresentou também alguns problemas para a comunidade nipônica já instalada no Brasil. As experiências desses novos imigrantes, que nasceram em um Japão consumido pela Guerra, foram muito distintas da vivência dos filhos de imigrantes japoneses no Brasil. Por conta de algumas divergências de valores, conflitos ocorreram no seio da colônia nipo-brasileira. Esses conflitos foram, de certa forma, representados pelas diferenças em relação à própria língua japonesa, que havia passado por

\footnotetext{
${ }^{21}$ Shindô-Renmei (cuja tradução é Liga do Caminho dos Súditos) foi uma organização secreta criada por imigrantes japoneses no Brasil após o final da guerra. Os membros dessa organização (conhecidos como "vitoristas") acreditaram piamente na vitória do Japão na Segunda Guerra Mundial e perseguiram, enganaram e assassinaram membros da colônia japonesa que foram contrários a essa ideia. Segundo Takeuchi (2007:76-84), integrantes da Shindô-Renmei assassinaram 23 imigrantes japoneses e feriram outros 147. Mais de mil imigrantes japoneses foram presos por participarem da Shindô-Renmei e a maioria só foi libertada em 1956, durante a presidência de Juscelino Kubitschek.

${ }^{22}$ Esse evento foi, contudo, apenas o ponto culminante de um sentimento antinipônico presente no Brasil desde o século XIX. Para uma melhor compreensão da gênese desse tipo de discurso em uma perspectiva histórica, indicamos o trabalho de Dezem (2008).
} 
mudanças de uma geração a outra, levando assim a uma considerável diferença entre a língua usada pela primeira geração de imigrantes (e que foi ensinada à segunda geração no Brasil) e a usada por aqueles que acabavam de chegar ao país depois da guerra (Sakurai, 2008: 221).

Os imigrantes das levas anteriores consideraram os novos imigrantes japoneses interesseiros e folgados, porque estes aproveitaram as melhores condições de acolhimento construídas por aqueles em décadas anteriores no Brasil. Os novos imigrantes acusaram os antigos de serem atrasados e mesmo "caipiras”, porque tiveram uma formação educacional mais baixa. Além disso, os novos imigrantes não consideraram os antigos imigrantes mais japoneses por não terem passado pelas agruras e misérias da Segunda Guerra Mundial, como o racionamento de alimento e de combustível e a alta taxa de desemprego. Até mesmo a cor da pele dos imigrantes mais antigos - mais escura por causa do trabalho diário na lavoura - foi motivo para exacerbação das diferenças na colônia japonesa instalada no Brasil (Sakurai, 2004: 20-21).

Os mais antigos recusaram os novos imigrantes como membros de suas respectivas famílias, nos casos em que um desses novos imigrantes tentou se casar com uma filha dos antigos imigrantes ${ }^{23}$. De um modo geral, para as famílias mais antigas, ter como membro da família um novo imigrante foi considerado um motivo de vergonha. Como boa parte desses novos imigrantes foi constituída por jovens solteiros do sexo masculino, a saída encontrada para resolver esse problema matrimonial para os novos imigrantes foi recorrer às "noivas por fotografia". Como explica Sakurai, as "noivas por fotografia" foram garotas e mulheres a procura de homens para casar, mas com a peculiaridade de que só se conheceriam no dia do casamento, pois antes o contato era feito a distância por um intermediário no Japão que mostrava as fotos das pretendentes. No caso em que aceitavam o pretendente, partiam rumo ao Brasil para se casarem. Segundo ainda a autora, foram realizados no Brasil, por meio desse tipo de noivado, cerca de 400 casamentos (Sakurai, 2004: 2122).

Na década de 1950, com o desenvolvimento econômico e a ampliação do parque industrial no governo Kubistchek, o mercado brasileiro passou a ser

\footnotetext{
${ }^{23}$ Segundo Sakurai, o momento de chegada dos novos imigrantes japoneses coincide com um grande deslocamento de famílias de origem japonesa do campo para a cidade.
} 
visto com interesse pelas multinacionais japonesas, tanto para a instalação de indústrias pesadas como para a produção de bens de consumo. O Japão, assim como outros países desenvolvidos, transferiu parte de suas indústrias pesadas e poluidoras para países periféricos, entre eles o Brasil. Dessa maneira, a entrada de trabalhadores japoneses especializados esteve também relacionada à vinda de multinacionais nipônicas para o país (Sakurai, 2008: 217-219).

Além dos japoneses, muitos imigrantes europeus vieram para o país, como vimos anteriormente. Diégues Jr. mostra que, entre os operários qualificados que entraram no Brasil no período 1945-1958, predominaram, nessa ordem, portugueses, espanhóis, italianos, libaneses, alemães e gregos. Já entre os técnicos qualificados para a indústria nacional, os italianos estiveram em primeiro lugar, seguidos por norte-americanos e alemães (Diégues Jr., 1965: 308-309).

Entre os imigrantes europeus que vieram para o Brasil, destaca-se o contingente espanhol. Segundo Dominguez, entre 1946-1972, entraram no país por volta de 130 mil imigrantes espanhóis, sendo que entre 1952-1955 foram os anos de maior fluxo de imigrantes espanhóis no país (2004: 62-63).

Uma parte dos imigrantes espanhóis, a partir de 1957, chegou com o auxílio do CIME. No entanto, a maioria desses imigrantes chegou ao país nesse período sem qualquer tipo de auxílio governamental. Muitos deles possuíam conhecimentos técnicos que foram aproveitados pela indústria automobilística, mas houve um grupo que se diferenciou dos demais que estiveram envolvidos na imigração espanhola: os galegos. Os galegos, que saíram do país, diferenciaram-se dos demais espanhóis por serem, em sua maioria, trabalhadores rurais sem formação escolar completa e por não estarem necessariamente vinculados ao movimento antifranquista na Espanha $^{24}$ (Peres, 2003: 35-37).

A imagem do Brasil divulgada por propagandas do governo brasileiro na Europa, depois da Segunda Guerra Mundial, foi muito mais fantasiosa do que realista. Assim, muitos imigrantes galegos decepcionaram-se quando se defrontaram com a real condição de trabalho aqui (problema comum

\footnotetext{
${ }^{24}$ Como eram indivíduos em geral humildes e sem formação escolar, os galegos não se envolviam nos problemas políticos espanhóis.
} 
encontrado por diversos imigrantes, como os japoneses e os italianos, por exemplo). Segundo Peres, três foram as principais desilusões dos imigrantes galegos que vieram nesse período: a primeira se referia às condições, muitas vezes miseráveis, encontradas nas cidades brasileiras, idênticas às que eles deixaram em sua região de origem; a segunda decorreu do fato de se exigir dos imigrantes carteira de trabalho, de identidade e de saúde, caras para eles e com uma demora de 25 dias para sua emissão (enquanto esses documentos não fossem emitidos, eles poderiam trabalhar com autorização provisória); a terceira desilusão esteve ligada à impossibilidade de permanecer nas cidades quando eles entravam no país com uma declaração de que seriam trabalhadores rurais (naquela época, a carteira de trabalho de um trabalhador rural era diferente da de um trabalhador urbano) (Peres, 2003: 69-70). Mesmo com esses problemas e decepções, grande parte os imigrantes galegos permaneceu no país.

Depois desse período subsequente ao final da Segunda Guerra Mundial, houve uma diminuição do fluxo imigratório no Brasil. Uma série de fatores foi responsável por essa diminuição: a retomada econômica dos países destruídos pela guerra, tanto na Europa quanto na Ásia (em especial, o Japão); a pouca duração do desenvolvimento econômico brasileiro e as taxas de inflação cada vez mais altas; o aumento das diferenças sociais no país, que já eram acentuadas, e a permanência da miséria; as crises políticas, principalmente na década de 1960 (Peres, 2003: 75). Essa década apresentou, assim, uma clara diminuição da entrada de imigrantes japoneses e europeus, ou seja, dos grupos imigratórios mais tradicionais na história brasileira, que passaram a contar com uma nova realidade em seus respectivos países.

Novos atores sociais vieram a ocupar o espaço de trabalho deixado pelos antigos grupos imigrantes. Mantiveram-se alguns traços da imigração tradicional, mas apareceram novas características, novas culturas, valores e línguas. Passemos, a seguir, a uma rápida apresentação da história da entrada desses novos estrangeiros no Brasil. 


\subsection{A vinda dos imigrantes coreanos e chineses para o Brasil $^{25}$}

No início da década de 1950, com o desenvolvimento industrial do país, procurou-se atrair mão-de-obra especializada, ou seja, técnicos e profissionais de nível superior vindos dos países europeus, como vimos acima. Isso não significou que somente imigrantes altamente especializados entraram no país: os imigrantes sem essa formação específica (e muitas vezes com uma escolaridade baixa) continuaram a vir para o Brasil. Assim, bolivianos, chineses e coreanos substituíram europeus e japoneses no papel de imigrantes que ocuparam postos de trabalho que não exigiram formação escolar completa. Nesta seção, trataremos de uma nova imigração asiática: a dos coreanos e a dos chineses.

Para Choi (1991; 1999), a imigração coreana para o Brasil pode ser dividida em cinco fases: a primeira, chamada de pré-imigratória pela pesquisadora, vai de 1910 a 1952, quando poucos coreanos (entre eles, alguns naturalizados japoneses) chegaram ao país; a segunda, conhecida como imigração pré-oficial, ocorreu no ano de 1962, quando 14 membros da Primeira Delegação Cultural entraram no país para preparar a estrutura para receber novos imigrantes coreanos; a terceira fase, a da imigração oficial propriamente dita, vai de 1963 a 1971, período em que chegaram tanto trabalhadores agrícolas (1963-1966), como técnicos para a indústria (1971). A quarta fase, denominada de imigração clandestina pela autora, caracterizou-se pela entrada de imigrantes indocumentados, sobretudo por meio de escalas no Paraguai, na Bolívia e na Argentina entre os anos de 1972-1980. Por fim, a última fase, conhecida como imigração em cadeia, e que existe até os dias atuais, é marcada pela vinda de imigrantes portadores de cartas de convite de parentes já estabelecidos no Brasil (Choi, 1996: 234-235).

Choi mostra que os primeiros imigrantes coreanos entraram no Brasil antes da Segunda Guerra Mundial, mais exatamente em 1918. Foram quatro

\footnotetext{
${ }^{25} \mathrm{O}$ único trabalho acadêmico significativo que encontramos sobre a imigração coreana no Brasil é de Keum Joa Choi (1991; 1996). Baseamo-nos em seu estudo para a elaboração desta seção.
} 
famílias que se naturalizaram japonês ${ }^{26}$. Além disso, Choi acredita na possibilidade de outros coreanos terem desembarcado no Brasil na condição de cônjuge de imigrantes japoneses (1991: 28-29).

Existiram ainda outras situações que propiciaram a vinda de outros imigrantes coreanos no período que Choi chama de fase pré-imigratória. Durante a Guerra Civil (1950-1953), responsável pela divisão da Coreia em dois países, 170.000 soldados norte-coreanos foram presos pelas tropas da ONU e enviados para o sul da Península Coreana (Choi, 1991: 29). Em 1953, o governo determinou a liberação de 20.000 dos 170.000 prisioneiros por terem se declarado anticomunistas. A maioria optou por permanecer no sul da Coreia, enquanto outros voltaram para o norte. Restaram por volta de 88 exprisioneiros com situação indefinida (segundo Choi, havia também chineses entre esses prisioneiros). Logo depois do armistício, ficou decidido ${ }^{27}$ que esses presos seriam encaminhados para países considerados neutros. Entre as possibilidades, a Índia se ofereceu em 1954 para abrigar parte dos exprisioneiros por um período de 2 anos. Após esse período, no entanto, não houve um destino certo para esses coreanos e foi preciso encontrar um país para recebê-los definitivamente. Assim, após recusa dos EUA e do México, Brasil e Argentina se ofereceram para receber parte desses ex-prisioneiros. Esses ex-prisioneiros (55 coreanos e 8 chineses) chegaram ao aeroporto do Rio de Janeiro no dia 06 de janeiro de 1956 e, em seguida, foram encaminhados para a Ilha das Flores, onde obtiveram regularização definitiva de sua situação no Brasil (Choi, 1991: 29-31).

Antes da imigração oficial, as relações diplomáticas entre Brasil e Coreia do Sul tiveram que ser reestabelecidas, o que ocorreu em 1959. Inicialmente, o governo coreano daquele momento foi contrário ao processo emigratório, porque não tinha condições financeiras e estruturais para acompanhar a situação de seus cidadãos no exterior. Com a tomada de poder pelos militares em 1961, a questão imigratória mudou de perspectiva porque o governo recéminstaurado implantou uma nova relação com outros países, o que facilitou a implantação de uma política imigratória (Choi, 1991: 33-34).

\footnotetext{
${ }^{26}$ A naturalização e a adoção de um nome japonês foram uma prática comum para os coreanos desse período, em que a Coreia foi uma colônia japonesa.

${ }^{27}$ Pelo trabalho de Choi, não foi possível saber qual país ou instância internacional decidiu o destino desses coreanos.
} 
Jânio Quadros, presidente do Brasil em 1961, mostrou-se particularmente interessado na vinda de coreanos para o país, principalmente de profissionais técnicos. Mas isso não se converteu em uma ajuda direta do governo brasileiro, como ocorrera em outros momentos da história da imigração no Brasil. O máximo que o governo se propôs a fazer foi doar terras do norte do país. Em agosto de 1961, o governo autorizou a vinda de 500 famílias, assim como a concessão de terras próximas ao Rio São Francisco. Mesmo com a renúncia de Jânio Quadros, o projeto de vinda de imigrantes coreanos prosseguiu e a Coreia do Sul inaugurou sua embaixada no Brasil em 1962 (Choi, 1991: 34-36).

Ainda em 1962, mais exatamente em 05 de janeiro, chegou a primeira delegação da Sociedade Cultural Coreia-Brasil ${ }^{28}$ (Choi, 1991: 28). Esse grupo veio para observar a situação agrícola do país, recolher dados sobre o processo imigratório no Brasil e também para se encontrar com autoridades governamentais. Alguns membros dessa delegação chegaram à conclusão de que as terras a serem cedidas pelo governo brasileiro não contribuiriam para a adaptação dos possíveis imigrantes coreanos por causa de sua localização (norte do país). Nessa ocasião, um dos membros da delegação (Inn Kyu Chung) conseguiu uma autorização do governo para trazer 116 famílias coreanas. Ele retornou a Coreia do Sul e conseguiu selecionar 30 famílias para virem ao Brasil (Choi, 1991: 38).

Em fevereiro de 1962, o governo coreano tomou providências para regulamentar o processo emigratório do país. Entre outras medidas, o governo coreano enviou, em 15 de março de 1962, uma comitiva oficial para tratar dos detalhes com o governo brasileiro. Das 30 famílias acima mencionadas, apenas 17 (em um total de 92 pessoas) conseguiram o visto para entrar no Brasil (Choi, 1991: 39-40).

As 17 famílias são consideradas a primeira leva oficial de imigrantes coreanos que chegou ao país, transportada pelo navio Tjitjalenka, no dia 12 de fevereiro de 1963, data que se tornou o dia oficial da imigração coreana no Brasil. Desde o começo, os imigrantes coreanos viriam para trabalhar em

\footnotetext{
${ }^{28}$ A imigração coreana oficial para o Brasil se diferencia das demais porque foi organizada principalmente por civis, membros da Sociedade Cultural entre Brasil e Coreia Queremos dizer com isso que as negociações foram mediadas pela Sociedade Cultural Coreia-Brasil, mas elas, obviamente, precisaram da aprovação do governo coreano.
} 
fazendas paulistas. No entanto, ainda na Coreia do Sul, esses imigrantes foram informados que seriam proprietários de terras no Brasil. Essa falsa informação foi passada por So Joo Kim, coreano que já morava no Brasil e que assumiu a responsabilidade pela compra das terras com o dinheiro dos imigrantes. Mas, na realidade, isso foi apenas uma tentativa de roubá-los, pois Kim pegou o dinheiro para comprar uma fazenda para ele e tinha a ideia de colocar os coreanos como seus os trabalhadores. Com os imigrantes já estabelecidos na Hospedaria dos Imigrantes em São Paulo ${ }^{29}$ e sem saberem exatamente para onde iriam (para as terras compradas ou para fazendas de outras pessoas), o embaixador coreano interveio para resolver o problema junto ao governo brasileiro. Mesmo sabendo que os imigrantes coreanos chegaram para trabalhar em fazendas, o governo autorizou, em caráter excepcional, os imigrantes coreanos a procurarem terras para comprar. Dessa forma, alguns imigrantes coreanos compraram terras para cultivo, outros alugaram terras de fazendeiros japoneses e um terceiro grupo foi trabalhar em fazendas paulistanas (Choi, 1991: 55-58).

Após essa primeira leva, mais quatro grupos vieram para o Brasil entre os anos 1963 e 1964. O segundo grupo foi encaminhado para a fazenda Ponta Grossa, na cidade de Vitória (ES), onde 24 famílias (por volta de 100 pessoas) se estabeleceram. A terceira leva, com 68 famílias (350 pessoas), também foi encaminhada para a mesma fazenda. Além de não terem conhecimento para o cultivo agrícola, os indivíduos dessas famílias não ficaram satisfeitos com as condições encontradas nessa fazenda e a grande maioria decidiu ir para a cidade de São Paulo ${ }^{30}$ (Choi, 1991: 59-60).

Em agosto de 1964, chegou a quarta leva de imigrantes coreanos no Brasil, formada por 50 famílias (285 pessoas). Eles chegaram ao Rio de Janeiro e algumas famílias permaneceram por lá, mas boa parte foi atrás de parentes que já estavam no país (Choi, 1991: 61-62). A quinta leva de imigrantes coreanos foi dividida em 3 grupos que chegaram em momentos distintos do ano de 1964 e trouxe para o país um total de 69 famílias (514 pessoas). Todos seguiram para a fazenda Santa Maria, no Paraná (Choi, 1991:

\footnotetext{
${ }^{29}$ Segundo Choi, esses imigrantes coreanos foram o último grupo a se instalar na Hospedaria dos Imigrantes.

${ }^{30}$ Muitos desses imigrantes se tornaram pequenos comerciantes (Choi, 1991: 80).
} 
63). Além dos imigrantes coreanos vindos por meios oficiais, outros entraram no Brasil com visto de turista e permaneceram depois do prazo do visto expirar, tornando-se, assim, imigrantes em situação irregular ${ }^{31}$ (Choi, 1991: 77).

Muitos coreanos chegaram ao Brasil, por meio de intermediários, também via Paraguai e Uruguai e a imagem de imigrante "clandestino" passou a ser associada ao coreano (Choi, 1991: 110). Esses imigrantes contaram, em alguns casos, com o auxílio de igrejas coreanas instaladas em São Paulo ou do Centro Pastoral dos Migrantes da Igreja nossa Senhora da Paz ou ainda de conterrâneos instalados em São Paulo (como emprego, moradia, alimentação etc.) (Choi, 1991: 115-116). Mas eles também foram bastante explorados, em outros casos, por imigrantes coreanos que viviam em situação regular no país, recebendo salários miseráveis e, às vezes, vivendo praticamente em cárcere privado (Choi, 1991: 117).

$\mathrm{Na}$ década de 1970, um grupo de coreanos chegou ao Brasil para trabalhar na indústria. Assim, em 1971, chegaram 1.400 coreanos na condição de técnicos portadores de diploma universitário. No ano seguinte, no entanto, o governo brasileiro interrompeu a imigração coreana oficial por causa dos problemas gerados pelos imigrantes que viviam em situação irregular no país (Choi, 1991: 78).

Os primeiros imigrantes que chegaram à cidade de São Paulo foram, em sua maioria, morar nas ruas do Glicério e Conde de Sarzedas, no bairro da Liberdade. Essa região ficou conhecida como a Vila Coreana. As razões para morarem nessa região são explicadas por Choi: a) o bairro foi habitado por muitos japoneses, o que facilitou a comunicação, já que muitos coreanos falavam japonês; b) o baixo preço do aluguel; c) a localização central do bairro. Foi na Vila Coreana que os coreanos começaram a trabalhar no comércio. Naquele momento, o papel da mulher coreana foi importante, pois algumas começaram a vender produtos trazidos da Coreia. Com o sucesso dessas vendas, alguns coreanos decidiram montar confecções para a produção de roupas. Assim, mulheres, homens e seus filhos trabalhavam durante longas jornadas para suprir a demanda dos pedidos de roupas por parte dos brasileiros (Choi, 1991: 95-96). As atividades comerciais dos coreanos foram

\footnotetext{
${ }^{31}$ Em seu trabalho, Choi não soube precisar a quantidade exata de coreanos nessa condição.
} 
se concentrando no bairro do Bom Retiro (antes, o comércio de coreanos estava disperso pelos bairros do Brás e da Mooca) (Choi, 1991: 98-100).

Muitos começaram com uma estrutura precária, envolvendo toda a família no trabalho de confeccionar roupas durante muitas horas do dia e da noite. Eles cuidavam de toda a linha de produção: o desenho e o corte da roupa, levar o tecido a uma oficina (para os que não tinham) e a venda direta ao cliente. Coreanos, que apenas vendiam as roupas, montaram oficinas ou lojas atacadistas Em pouco tempo, eles profissionalizaram a produção e contrataram mais trabalhadores para suas confecções, principalmente conterrâneos sem capital para abrir seu próprio negócio ${ }^{32}$ (Choi, 1991: 103104).

A preocupação com o desenho das roupas (ao gosto dos clientes brasileiros), o trabalho contínuo envolvendo toda a família (aos sábados, domingos e feriados), os preços baixos praticados em relação ao mercado e a concessão de um prazo mais longo para o pagamento das peças vendidas (90 dias), em um momento de instabilidade econômica brasileira (que convivia com altas taxas mensais de inflação), foram os fatores responsáveis pela empreitada bem sucedida dos coreanos no ramo de roupas. Dessa forma, os coreanos venceram a "competição" contra comerciantes judeus, árabes e japoneses no ramo da confecção (Choi, 1991: 105-106).

Obviamente, o modo como os coreanos se colocaram no mercado de roupas criou uma imagem negativa deles em relação a outras comunidades estrangeiras, principalmente os judeus (Choi, 1991: 107). Mas nem todos os comerciantes coreanos foram bem sucedidos nessa competição. Muitos tiveram que fechar as portas e procurar trabalho em outras áreas (Choi, 1991: 106).

Segundo Choi, as atividades em torno da confecção ou do comércio de roupas fizeram com que a comunidade coreana no Brasil permanecesse fechada às demais comunidades e à sociedade brasileira, em um movimento conhecido por outros grupos imigrantes no Brasil. E como ocorreu com as demais comunidades, vê-se um aumento lento, mas efetivo, de abertura dessa comunidade, sobretudo a partir do momento em que a segunda geração chega

\footnotetext{
${ }^{32} \mathrm{Na}$ época de sua pesquisa, Choi afirma que $90 \%$ dos coreanos trabalhavam, direta ou indiretamente, no comércio de roupas (1991: 103).
} 
às faculdades e passam a exercer novas atividades, não necessariamente ligadas à confecção de roupas. De qualquer forma, a manutenção dos valores do país de origem, assim como de sua cultura e de sua língua, permanece como uma das características desse grupo até os dias atuais (Choi, 1996: 237238).

Em relação aos chineses ${ }^{33}$, há registros de sua entrada no país desde o século XIX. No entanto, um número maior de imigrantes chineses entrou no país depois de 1945, principalmente em decorrência da Revolução Chinesa e também da carência brasileira de mão-de-obra especializada. Embora houvesse registros de imigrantes chineses trabalhando na agricultura, essa imigração foi predominantemente urbana. Eles se estabeleceram majoritariamente em São Paulo e se dedicaram, principalmente, ao comércio (Freitas, 2007: 143-144).

Uma parcela significativa de chineses que vieram para o Brasil partiu de Taiwan. Isso ocorreu após a Revolução Chinesa, em 1949, quando alguns chineses deixaram seu país em direção a Taiwan. Foi desse país que um novo movimento emigratório partiu para vários países, entre os quais o Brasil. Esses imigrantes possuíam, de um modo geral, formação técnica mais qualificada do que os que chegaram ao Brasil no século XIX. Muitos, ao chegar ao Brasil, optaram por trabalhar no comércio, como bazares, restaurantes e pastelarias, mas, como aconteceu com quase todos os imigrantes, tiveram a preocupação em dar uma boa educação a seus filhos. Por isso, atualmente, são encontrados descendentes de chineses em cursos concorridos, como engenharia, medicina e direito. Além disso, há um movimento recente de muitos chineses que chegam ao país para atuar na área acadêmica (Mei, 2007: 14-15).

Nas décadas de 1970 e 1980, em um movimento parecido com o dos coreanos, imigrantes chineses entraram no Brasil, em sua maioria, via Paraguai, com documentos falsos ou sem visto. Para regularizar sua situação no país, muitos chineses solicitaram um novo passaporte no consulado, alegando perda de documentos (Freitas, 2007: 143-144).

Esses problemas de documentação não foram, contudo, exclusividade dos imigrantes chineses ou coreanos. Eles envolveram, e ainda envolvem, os

\footnotetext{
${ }^{33}$ Infelizmente, ainda não existe um trabalho sistemático sobre os momentos mais significativos da imigração chinesa recente no Brasil.
} 
imigrantes latino-americanos. Veremos, a seguir, como se formou historicamente o movimento imigratório de latino-americanos para o Brasil.

\subsection{A entrada dos imigrantes latino-americanos ${ }^{34}$}

O movimento imigratório de latino-americanos para o Brasil é um fenômeno significativo, apesar de em termos quantitativos não se equiparar às grandes imigrações de europeus e asiáticos. Uma de suas características é a de envolver indivíduos com grande diversidade de formações, de origens e de motivos para sair de seus respectivos países.

Ainda na década de 1950, começou a imigração em massa de latinoamericanos para o Brasil. Nas décadas seguintes, sobretudo a partir de 1980, houve um substancial aumento da imigração de latino-americanos (principalmente bolivianos) (Oliveira, 2006: 9).

O fluxo imigratório de latino-americanos conheceu um verdadeiro "boom" a partir da década de 1970, quando o processo de industrialização de alguns países, como Argentina, Venezuela e Brasil, cresceu significativamente (Silva, 2005: 14-15). O desenvolvimento industrial, e no caso do Brasil, o chamado "milagre econômico", tornou esses países objeto de atração de imigrantes latino-americanos. Além disso, ainda na década de 1970, muitos imigrantes latino-americanos, como chilenos, uruguaios e argentinos, buscaram o Brasil para fugir dos regimes ditatoriais de seus respectivos países. Esses imigrantes, considerados refugiados políticos, apresentaram uma formação escolar alta ${ }^{35}$ (Silva, 2005: 15).

Tratando especificamente dos imigrantes bolivianos, os primeiros chegaram ao Brasil na década de 1950 com o objetivo principal de estudar ${ }^{36}$. Boa parte desses imigrantes veio para o país com o intuito de fazer faculdade de engenharia ou de medicina e, por diferentes motivos, muitos acabaram

\footnotetext{
34 Esta seção é baseada, sobretudo, nos estudos do antropólogo Sidney Antonio da Silva, um dos principais pesquisadores da imigração boliviana no Brasil.

35 Silva não menciona, mas veremos abaixo que os imigrantes latino-americanos perseguidos politicamente pelos seus países são, na realidade, refugiados que entraram no Brasil para serem transferidos posteriormente para outros países.

${ }^{36}$ A década de 1950 serve de marco histórico para se compreender a imigração boliviana no Brasil porque foi o período em que o número de imigrantes bolivianos que entraram no país passou a ter certa relevância, no sentido de indicar que um movimento migratório estava se constituindo. Contudo, isso não significa que, antes dessa década, imigrantes bolivianos não entraram no país (Silva, 1997: 84).
} 
permanecendo no país, tornando-se profissionais liberais ou pequenos empresários (Silva, 1997: 82).

Os imigrantes bolivianos que chegaram na década de 1970 vieram para trabalhar e ocuparam as vagas de pequenas confecções, muitas delas controladas naquele momento pela comunidade judaica (que, posteriormente, foi substituída quase que completamente pelos imigrantes coreanos).

Na década de 1990, uma nova leva de imigrantes bolivianos e de outros imigrantes latino-americanos surgiu em decorrência da estagnação econômica e da instabilidade política de alguns países (Silva, 2007: 74) 37 .

De modo geral, os bolivianos que chegaram (e continuam chegando) ao país possuem as seguintes características: jovens, solteiros, boa parte do sexo masculino (se bem que a presença feminina tem aumentado consideravelmente) e com nível escolar médio (mas alguns são profissionais liberais) ${ }^{38}$ (Silva, 2005: 16). Boa parte desse contingente dirigiu-se à cidade de São Paulo, mas há também comunidades em cidades fronteiriças e em outras grandes capitais brasileiras, como Belo Horizonte e Rio de Janeiro (Silva, 2005: 17-18).

A principal atividade de trabalho desses imigrantes (com exceção dos profissionais liberais) sempre foi nas oficinas de costura que, muitas vezes, apresentam condições insalubres de trabalho. Além disso, de um modo geral, esses imigrantes nunca puderam exigir seus direitos trabalhistas previstos pela CLT, porque não possuíam carteira de trabalho.

Esses imigrantes chegaram por meio de empresas bolivianas encarregadas de transportá-los para o Brasil, onde eles encontraram uma rede de contratação já estabelecida pelos compatriotas que vieram em anos anteriores. Os bolivianos foram (e continuam sendo) atraídos por uma série de vantagens aparentes e por promessas de trabalho bem remunerado. Contudo, ao se estabelecer, eles perceberam que a realidade não foi exatamente a prometida. Muitos bolivianos não conseguiram o visto permanente para

\footnotetext{
${ }^{37} \mathrm{O}$ autor se refere, principalmente, a países como Peru e Colômbia (e a ascensão, respectivamente, do Sendero Luminoso e das FARC) (Silva, 2007: 73).

38 Silva ainda nos mostra que muitos imigrantes bolivianos (e de outras nacionalidades latinoamericanas), que possuem uma consistente formação escolar, não têm os documentos necessários para regularizar sua situação no país e acabam trabalhando em oficinas de costura para poder sobreviver (2007: 76-77).
} 
trabalhar no país e, por isso, arriscaram a entrada com o visto de turista. Dessa forma, muitos trabalharam de forma irregular, do ponto de vista da legislação brasileira, e ainda foram expulsos por sua situação irregular (Silva, 2005: 1820).

Por estarem em situação irregular, esses imigrantes se submeteram a formas de exploração por parte dos empregadores (que frequentemente são seus próprios compatriotas), como, por exemplo: baixa remuneração (relativa, ainda, à produtividade de cada trabalhador), relação de dependência (porque muitos empregadores "oferecem" a seus funcionários casa e comida) e longas jornadas de trabalho diário (em muitos casos, 16 horas diárias de trabalho) (Silva, 2005: 19-20). Esses trabalhadores viveram constante tensão, porque a qualquer momento funcionários do governo apareciam para conferir a situação de cada um dos trabalhadores. Um exemplo disso ocorreu com a proposta do Ministério da Justiça de criar um "disque-denúncia" contra a exploração desses trabalhadores. Esse serviço, no entanto, foi utilizado para desbaratar oficinas que estavam em "competição" no mercado, criando um clima de perseguição na comunidade boliviana (Silva, 2005: 23).

Com um número crescente de imigrantes bolivianos em situação irregular, o governo brasileiro, ainda durante a década de 1980, promoveu uma política de anistia a esses trabalhadores (e a trabalhadores de outras origens que viviam a mesma situação de irregularidade). Dessa forma, esses trabalhadores obtiveram os documentos necessários para trabalhar regularmente no país. Contudo, segundo Silva, nem todos os trabalhadores "indocumentados" puderam participar da anistia por causa dos altos custos referentes a taxas e da quantidade de documentos que deveriam ser apresentados (Silva, 2005: 25-26).

Para contornar a situação irregular no país, há toda uma rede de autoproteção dos imigrantes bolivianos, assim como meios legais para regularizar sua situação no Brasil (como, por exemplo, ter um filho nascido no país) (Silva, 2005: 34-36). Essa rede também serve para diminuir a solidão dos imigrantes bolivianos, um grande problema, porque muitos são solteiros e chegam ao país sem conhecer ninguém (2007: 76). 
Outra característica desse grupo está na alta mobilidade. Muitos imigrantes bolivianos já haviam migrado de cidades menores para as grandes cidades bolivianas e, em seguida, emigraram para o Brasil. Mas essa característica foi marcante até os anos 1980: na década de 1990, como mostra Silva, muitos imigrantes saíram diretamente das pequenas cidades diretamente para o Brasil. Segundo o mesmo autor, essa mudança de uma cidade pequena para São Paulo, por exemplo, representa uma dificuldade a mais para a adaptação do imigrante boliviano, uma vez que a passagem de uma cidade menor, em que supostamente todos se conhecem, para uma cidade grande, simbolicamente opressora e onde se vive, na maior parte do tempo, com o sentimento de solidão, pode ser entendida como uma mudança muito radical (Silva, 2007: 76).

Além desses problemas vivenciados pelos imigrantes bolivianos, esse grupo sofreu (e ainda sofre) uma série de preconceitos e de discriminações relacionada às diferenças culturais. A discriminação decorreu, segundo Silva, do fato de a Bolívia possuir uma imagem de país atrasado, pobre e de origem indígena, além de ser associada ao tráfico de drogas. Essa discriminação também foi estendida aos filhos dos imigrantes nas escolas, porque a eles foi muitas vezes imputada a imagem de "índios" 39 (por conta de seus traços fenotípicos) (Silva, 2005: 25-26).

Ainda segundo Silva, todo imigrante de origem andina é considerado ainda hoje "boliviano", embora haja imagens preconceituosas específicas para cada grupo. Os bolivianos são, segundo o autor, frequentemente considerados "costureiros, pobres e índios", enquanto os peruanos são indivíduos que praticam "atividades ilícitas", como o "roubo e venda de objetos roubados". Já os paraguaios, por conta da imagem que muitos brasileiros constroem do Paraguai, têm sua imagem relacionada a mercadorias falsificadas (Silva, 2007: 81-84).

Silva relata em seu trabalho um exemplo de intolerância ocorrido em São Paulo contra os imigrantes bolivianos. A Praça Padre Bento, no bairro do

\footnotetext{
${ }^{39}$ Entretanto, os imigrantes não são apenas vítimas do preconceito, mas eles também portam os seus. Segundo uma pesquisa realizada por Silva, os imigrantes latino-americanos mostram preconceito quando se referem aos demais imigrantes latino-americanos. Em alguns casos, o traço negativo destacado é o mesmo existente na sociedade brasileira, mas, em outros casos, o que fica evidente é a disputa regional entre os países (Silva, 2007: 87-88).
} 
Pari, passou a ser frequentado pelos imigrantes bolivianos que, progressivamente, instalaram, todo final de semana, uma feira onde produtos típicos da cultura e da culinária boliviana eram vendidos. Com o aumento no número de visitantes, alguns problemas, como sujeira, barulho e até casos de brigas, começaram a surgir. Os moradores que vivem no entorno da praça decidiram, então, organizar um abaixo-assinado para expulsar os bolivianos da praça. Para explicitar a insatisfação dos moradores, foi colocada uma faixa com os seguintes dizeres: "A praça é nossa! Exigimos respeito. Estamos aqui há mais de cem anos". Após esse protesto, a prefeitura de São Paulo decidiu mudar o local da feira dos imigrantes bolivianos para a Praça Kantula que, segundo o autor, fica no mesmo bairro, mas em um local mais isolado (Silva, 2005: 30-31).

Mesmo com tantos problemas, concorrências, explorações e desconfianças, há imigrantes que conseguem ascender socialmente dentro do seu grupo por meio do trabalho e da poupança, chegando a montar oficinas de costura próprias. O ciclo se reinicia: novas oficinas de costura são montadas e buscam, assim, novos imigrantes ansiosos para trabalhar e com muitos sonhos de melhorar de vida. Há ainda casos de filhos de imigrantes que retornam à Bolívia para cursar faculdades (Silva, 2005: 35).

As dificuldades de adaptação perpassam todos os grupos imigrantes, em qualquer fase da história da imigração no Brasil. Em determinados momentos, essas dificuldades se agravam quando estão envolvidos atitudes e comportamentos intolerantes e preconceituosos por parte da sociedade que deveria acolher esses imigrantes.

Nos últimos anos, o Brasil recebeu (e continua a receber) grande número de imigrantes de origem latino-americana e asiática. Mas o país passou a receber também outra forma de estrangeiro, que chega ao país em condições muito diferentes das dos imigrantes. Trata-se do refugiado. Abaixo, veremos em linhas gerais um pouco da história dessa outra forma de alteridade. 


\subsection{Outra forma de estrangeiro no Brasil: o refugiado}

Vimos, no começo deste capítulo, que o refugiado surgiu com o final da Segunda Guerra Mundial. Esses foram indivíduos que desejaram sair de seu país devastado pela guerra. Mas a figura do refugiado não existiu apenas no momento de uma guerra na proporção como foi a que terminou em 1945. A figura do refugiado continua atual. A diferença é que, nos dias atuais, o refugiado não está, necessariamente, envolvido em uma guerra. Sua definição é um pouco mais ampla: basicamente, o refugiado é de um sujeito perseguido por motivos diversos (como raça, religião, opção política etc.) em seu país de origem.

O Brasil foi um dos países signatários da Convenção de 1951 que criou a $\mathrm{ACNUR}^{40}$ e recebeu uma grande quantidade de europeus na condição de refugiados ${ }^{41}$ (Moreira, 2007: 5). Como o Brasil adotou a reserva geográfica, o país só aceitou receber refugiados do continente europeu. Desde então, essa situação perdurou durante o regime militar. No final dos anos 1970, refugiados latino-americanos, que fugiram dos regimes ditatoriais de seus países, permaneciam por pouco tempo no Brasil, pois eles eram reassentados em outros países, como os europeus, os Estados Unidos, Canadá, Nova Zelândia e Austrália" ${ }^{42}$ (Haydu, 2009: 189; Moreira, 2007: 5).

Mesmo com a reserva geográfica, o Brasil recebeu em caráter excepcional alguns refugiados que não vinham da Europa. Esse foi o caso de 150 vietnamitas em 1979. Mas o governo brasileiro não os reconheceu como refugiados. Para recebê-los, o governo brasileiro emitiu o visto de entrada temporário, que permitiu a esses refugiados trabalhar legalmente no país. No mesmo ano, o país recebeu dezenas de refugiados cubanos $^{43}$ (Moreira, 2007: $6)$.

\footnotetext{
${ }^{40}$ A ACNUR (Alto Comissariado das Nações Unidas para o Refugiado) substituiu a OIR (Organização Internacional para os Refugiados) com a diferença de que esta organização cuidou apenas dos refugiados da Segunda Guerra Mundial, enquanto aquela cuida dos refugiados de todo o mundo (Haydu, 2009: 186)

${ }^{41}$ O número de refugiados recebidos pelo Brasil nesse período pós-1945 varia bastante em dois trabalhos consultados. Enquanto Moreira (2007) menciona por volta de 40 mil refugiados, Haydu (2009) afirma serem 29 mil refugiados europeus.

${ }^{42}$ Segundo Moreira, foram por volta de 20 mil refugiados latino-americanos que passaram pelo Brasil (2007: 5).

${ }^{43}$ No caso dos refugiados cubanos, Moreira não apresenta muitas outras informações.
} 
Em 1986, o Brasil recebeu 50 famílias iranianas que tiveram que sair do país por causa das perseguições religiosas. Mas, ainda por causa da reserva geográfica, os iranianos só puderam ser recebidos porque foram enquadrados pela lei de asilados políticos. A reserva geográfica só terminou oficialmente em 1989 com a mudança do regime político que o país vivia (Haydu, 2009: 190; Moreira, 2007: 6).

Com a exclusão da reserva geográfica, o país começou a reconhecer refugiados de outras origens. O Brasil acolheu por volta de 1.200 angolanos entre os anos 1992-1994. Esses angolanos estavam fugindo de seu país por causa da violência generalizada após as eleições que ocorreram em 1992 (Haydu, 2009: 191; Moreira, 2007: 6).

Depois da criação do Estatuto do Refugiado, em 1997, o país começou a receber um número maior de refugiados. O primeiro grupo chegou em 2001, formado por 23 afegãos que foram encaminhados para Porto Alegre. Em 2003, o país recebeu mais 75 colombianos que viviam na Costa Rica e no Equador ${ }^{44}$ (Moreira, 2007: 8).

Andrade e Marcolini, em um trabalho de 2002, estimam em 2,7 mil refugiados vivendo no Brasil. Esses refugiados dividem-se em 47 nacionalidades e, além dos já citados angolanos, há ainda outros refugiados de origem africana, como liberianos (250), congoleses (160) e serra-leoneses (130). Outros refugiados são iraquianos (70) e outros são cidadãos vindos da antiga lugoslávia (100). Ainda há cerca de 10 colombianos que fugiram de seu país por causa dos conflitos entre guerrilheiros, paramilitares e a Força Pública colombiana (Andrade e Marcolini, 2002: 171-172). Em dados mais recentes, podemos observar um significativo aumento no número de refugiados no país:

Por fim, o Brasil abriga a maior população refugiada na América do Sul, em torno de 3.458 pessoas, e recebeu 195 solicitações de refúgio (com base na estatística de 2005). A maioria dos refugiados acolhidos no país provém da Angola, perfazendo 1.751 indivíduos. Em seguida, aparece a Colômbia, com 360 refugiados, depois a Libéria, com 261, República Democrática do Congo, com 207 e Serra Leoa, com 135. Já os solicitantes de refúgio são, na maioria, colombianos, totalizando 137 pessoas, seguidos pelos congoleses (88), pelos cubanos (61), angolanos (59) e peruanos (47) (Moreira, 2007: 9).

\footnotetext{
${ }^{44}$ A autora não menciona, mas supomos que esses colombianos já eram refugiados na Costa Rica e no Equador, sendo então o Brasil o local do reassentamento desses indivíduos.
} 
Atualmente, o Brasil tem um papel importante no acolhimento de refugiados espalhados pelo mundo. Segundo informações retiradas do relatório da ACNUR por Moreira, o Brasil é o $12^{\circ}$ país entre os que mais recebem refugiados no mundo (Moreira, 2007: 8).

Dessa forma, a entrada de estrangeiros, sejam imigrantes, sejam refugiados, continua a ser uma realidade na história do Brasil. Como vimos neste capítulo, os estrangeiros instalados no país podem ser vistos de modo positivo ou negativo pela sociedade e pelo Estado brasileiros. Podemos propor que a construção das imagens positiva ou negativa do estrangeiro no país é produto de uma postura intolerante ou tolerante da sociedade e do Estado que o recebem. Por isso, no próximo capítulo, apresentaremos algumas definições para as noções de intolerância e de tolerância. 


\section{Considerações acerca dos conceitos de tolerância e de intolerância}

\subsection{Introdução}

A relação humana diária é permeada por uma série de simulacros: podese conhecer uma pessoa e quase que imediatamente tirar algumas conclusões a respeito dela. Ela pode ser simpática, inteligente, prestativa ou confiável. Por outro lado, é possível também considerá-la estranha, excêntrica ou pouco confiável. Nesse caso, a tendência é a de se afastar dessa pessoa, porque seu modo de ser é muito diferente daquilo que se considera positivo em alguém.

Nessas situações, colocar-se diante de um desconhecido ou do inabitual é colocar os próprios valores em jogo, porque são acionados imediatamente em uma interação social, até certo ponto banal, mas com sérias implicações no cotidiano. Esse rápido e simplório exemplo pode nos servir como base para se pensar no preconceito.

Quando o estranhamento ou o incômodo, que uma determinada presença suscita, leva a pessoa incomodada a um ato violento, nós já estamos na esfera da intolerância. Dessa forma, um sujeito intolerante é aquele que segrega, discrimina e, nos casos mais radicais, parte para a violência física propriamente dita para afastar ou eliminar uma presença desconhecida ou simplesmente diferente.

Uma atitude oposta é a de aceitar a diferença do outro, de seus valores, de seus comportamentos e de seus hábitos, mesmo que não se concorde completamente com isso. Um sujeito tolerante é, então, aquele que aceita a diferença e convive sem maiores problemas com ela, sem ceder seus próprios princípios e valores.

Neste capítulo, vamos apresentar algumas definições dos conceitos de intolerância e de tolerância, enquanto modos distintos de interação entre identidade e alteridade.

A primeira seção apresenta a intolerância e a tolerância em uma perspectiva histórica, ou seja, como esses conceitos se formaram e como serviram para mediar as relações no passado. Em seguida, algumas definições contemporâneas da intolerância e da tolerância serão apresentadas a partir de textos de intelectuais que trataram do tema. Outra seção foi reservada para 
mostrar algumas definições "graduais" da tolerância e da intolerância e para realizar uma síntese desses conceitos. A última seção foi reservada para descrever algumas noções relacionadas ao racismo, à xenofobia e à intolerância linguística, formas de intolerância que, em alguma medida, interessam mais de perto ao nosso trabalho.

\subsection{Breve história da tolerância e da intolerância}

A Grécia Antiga é considerada o berço da democracia. Frequentemente, são citados exemplos de como seus cidadãos foram considerados todos iguais perante a polis, porque todos tiveram igualmente o direito ao voto e à livre expressão no espaço de debates na praça. No entanto, na polis, houve restrições políticas a determinadas classes de indivíduos que foram excluídos da prática democrática grega (Le Goff, 2000: 38). Esse foi o caso dos escravos, das mulheres e dos metecos (estrangeiros ${ }^{45}$ que viveram na polis), que não possuíram direitos políticos ou sociais (no caso dos escravos) e, consequentemente, não tiveram o reconhecimento de cidadãos plenos.

No Império Romano, houve uma longa história de perseguições aos cristãos. Esse cenário intolerante contra os cristãos perdurou até a ascensão do imperador Constantino, que não apenas reconheceu e legalizou o cristianismo, mas também o elevou à condição de religião oficial do Império Romano (Cardoso, 2003: 24). Além da perseguição aos cristãos, os romanos também chamaram de bárbaros todos os povos que não possuíram leis que organizassem a vida social (Santos, 1984: 21).

O conceito de tolerância, segundo Cardoso, surgiu na Baixa Idade Média por meio do pensamento humanista associado à burguesia nascente. Ambos defendiam os valores da liberdade e do individualismo em oposição aos valores tradicionais defendidos pela Igreja Católica e pela nobreza feudal (Cardoso, 2003: 27-28).

Durante a Alta Idade Média, houve um período de conversões (forçadas ou não) de judeus ao cristianismo. Ao mesmo tempo, medidas preventivas

\footnotetext{
${ }^{45}$ Os gregos chamavam os estrangeiros de bárbaros porque os gregos acreditavam que uma língua diferente e incompreensível não poderia ser produzida por um pensamento articulado como o dos próprios gregos (Santos, 1984: 20-21).
} 
foram tomadas em relação aos muçulmanos que viveram nas vilas medievais. Em outras palavras, os muçulmanos foram mantidos em guetos frequentemente controlados (Le Goff, 2000: 39). Nessa época, foram também considerados inferiores todos os que não fossem cristãos: árabes, africanos, asiáticos (Santos, 1984: 21). Ainda na Idade Média, a relação entre Estado e religião tornou-se a base para a intolerância religiosa, que passou a perseguir os chamados hereges e ímpios, cujas formas mais radicais de perseguição foram as Cruzadas (a partir do século X) e a Inquisição (a partir do século XI) (Cardoso, 2003: 25-26).

As perseguições da Igreja Católica apresentaram, muitas vezes, a mesma lógica posteriormente usada na formação dos Estados Nacionais: criar uma sociedade livre de elementos inassimiláveis ou contrários aos preceitos cristãos, que poderiam "contaminar" uma sociedade que visaria à pureza do espírito e à homogeneidade de práticas religiosas (Le Goff, 2000: 40). No entanto, os alvos da perseguição religiosa não se limitaram apenas a outros grupos religiosos. Figuras proeminentes da época, como Giordano Bruno, Tomaso de Campanela e Galileu Galilei foram vítimas da intolerância cristã por causa de ideias que colocaram em dúvida as certezas e os valores pregados pela Igreja Católica $^{46}$ (Mereu, 2000: 44). De certa maneira, a intolerância religiosa do período medieval não deixou de ser um pretexto para a intolerância intelectual ou mesmo para camuflar a luta pelo poder do Estado naquele momento.

Ainda no século XVII, a tolerância esteve ligada essencialmente à resolução política dada às tensões religiosas daquele momento. Dessa forma, a liberdade de consciência ficou restrita à esfera privada, enquanto uma permissão do rei. No plano público, a única religião permitida foi a do rei. Ainda no contexto do lluminismo, segundo Falcon, a burguesia e parte da nobreza valeram-se da tolerância como uma estratégia para minar a riqueza, os privilégios e a influência da Igreja nos momentos em que houve uma disputa

\footnotetext{
${ }^{46}$ Perseguição semelhante ocorreu na Grécia, quando Sócrates fora condenado à morte, e na Holanda, quando a comunidade judaica decidiu que Espinosa não poderia mais manter relações com qualquer outro membro da comunidade. Em ambos os casos, houve uma espécie de conflito entre Religião (da polis e da comunidade judaica) contra a Filosofia (de Sócrates e de Espinosa) (Miranda, 2007: 22).
} 
em torno dos mesmos interesses ${ }^{47}$. Assim, todas as vezes que ocorreu uma disputa entre a sociedade civil e a lgreja, os burgueses e a nobreza apelaram para o princípio de tolerância para afirmar que a Igreja, enquanto instituição, não poderia ser intolerante, mas sim solidária e caridosa (Falcon, 1994: 67).

Essa noção de benevolência como base da tolerância foi substituída com o advento do lluminismo ${ }^{48}$, quando a tolerância passou a ser respaldada pelo conceito de razão. A tolerância passou a ser, assim, associada a uma vontade do indivíduo e não mais como uma concessão das instituições (Igreja e Estado). Como afirma Falcon,

Coube ao lluminismo dar o impulso final no sentido de fazer da tolerância um princípio de ordem geral, imposto pela razão, algo inerente à natureza humana e não mais uma concessão outorgada pela autoridade estatal. Nesse contexto ela é entendida como um dever moral (grifo do autor, 1994: 66).

A instauração da razão universal produziu um interesse pelo que é comum a todos os homens, ao mesmo tempo em que procurou apagar as diferenças que foram utilizadas como justificativa para a intolerância (Aurélio, 1996: 183). Além do mais, a racionalidade surgiu como forma de se lutar contra os preconceitos e as paixões (associadas à religião), que ofuscariam a ideia de igualdade. A razão foi, assim, a responsável pela elevação da tolerância, da igualdade e da liberdade como valores humanitários em oposição ao preconceito, às paixões e à intolerância contra o outro, enquanto valores defendidos pelas religiões (Aurélio, 1996: 188-190). Em resumo, a tolerância, junto com a igualdade e a liberdade, passou a ser um dos elementos universal e necessário para as relações entre os homens.

Se a razão universal foi responsável pela disseminação do que é comum a todos os homens, ela também pode ser usada para a produção da intolerância. Aurélio parte do seguinte princípio: se a tolerância é baseada na

\footnotetext{
${ }^{47}$ Desse embate entre a burguesia e a Igreja surgiram as chamadas revoluções burguesas, que tiveram como base a ideia de liberdade de pensamento e de tolerância religiosa, se contrapondo, assim, ao discurso da Igreja (Cardoso, 2003: 27). No entanto, a história nos mostra que, após conquistar o poder, as revoluções burguesas também descambaram, em grande parte, em regimes intolerantes, tal como mostraram os desdobramentos da Revolução Francesa.

${ }^{48}$ Segundo Mario Miranda Filho, houve dois momentos "iluminados" na história da humanidade: além do próprio Iluminismo, o autor mostra que já na Antiguidade Clássica o conceito de tolerância era considerado uma virtude, pois a sabedoria (uma das quatro virtudes) englobava uma "ativa solidariedade para com os amigos e inferiores" (s/d: 30). Nesse caso, Miranda aproxima os conceitos de solidariedade e tolerância. No decorrer deste capítulo, tentaremos apresentar uma distinção desses conceitos.
} 
razão universal que torna todos os homens iguais, como essa razão lida com o que está fora desse princípio de igualdade? Uma resposta simples seria: mantê-los continuamente fora. Aurélio aponta, assim, diferentes religiões como as primeiras vítimas dessa razão universal, pois foram associadas ao preconceito e à superstição. A razão, considerada a detentora da verdade universal, passou a ser uma forma de credo para alguns. Logo, os defensores da razão tornaram-se incapazes de exercitar a tolerância em relação àqueles que não foram incluídos no rol de seus valores, ou seja, as religiões (Aurélio, 1996: 190-191). Como diz o autor:

A razão, promovida a dispositivo da verdade, transformava-se, por sua vez, em credo, resvalando os deístas para procedimentos em tudo semelhantes aos dos membros de uma qualquer seita, a começar pela exibição da sua própria condição de mártires e perseguidos (Aurélio, 1996: 191).

Os valores religiosos foram substituídos pelo que o autor chama de uma "nova doutrina": os direitos sagrados dos cidadãos (Aurélio, 1996: 192). A liberdade, a igualdade e a razão produziram um efeito paradoxal ao englobar, em sua universalidade, comportamentos igualmente intolerantes. Por exemplo, o movimento da Revolução Francesa e de outras revoluções que, em nome da igualdade, eliminaram todos aqueles que não se incluíram ou não quiseram se incluir nas práticas e nos valores revolucionários, tal como a nobreza e o alto clero (Aurélio, 1996: 195). Outro claro exemplo, não citado pelo autor, está na própria Revolução Russa e no extermínio da família real e de parte da burguesia existente na Rússia ${ }^{49}$.

Desde a Grécia, grupos foram excluídos do convívio e da participação direta nas instâncias públicas de decisão da coletividade. Muitos outros foram segregados e perseguidos em nome de um deus, da razão, de sua opção política ou por simplesmente possuir uma opinião divergente. O advento da modernidade não apagou os problemas gerados pela intolerância contra grupos minoritários ou simplesmente diferentes dos que detinham (ou ainda detêm) o poder. O problema permanece até os dias atuais. Por isso, intelectuais de diversas áreas e de presenças variáveis no espaço público

\footnotetext{
${ }^{49}$ A despeito desses atos intolerantes, deve-se creditar às revoluções muitos avanços para a humanidade, pois elas não surgiram apenas como uma mera disputa pelo poder político de um Estado, mas sim como uma reposta a situações de forte opressão e exploração por parte das elites dirigentes (nobres, burgueses, clero) em cada um dos países mencionados.
} 
continuam a pensar, a discutir e a debater o problema da intolerância e de suas consequências contemporâneas. A seguinte seção trata justamente da forma como esses intelectuais compreendem a noção de intolerância nos dias atuais.

\subsection{Definições contemporâneas dos conceitos de intolerância e de tolerância}

Veremos, nesta seção, algumas definições de intolerância e de tolerância. Inicialmente, apresentaremos as definições de intolerância propostas por intelectuais e por pesquisadores. Em seguida, passaremos às considerações sobre a noção de tolerância com os mesmos autores.

Umberto Eco, filósofo e semioticista, afirma que o antissemitismo, 0 racismo pseudocientífico, o fundamentalismo religioso, entre outras, são "posições teóricas" que pressupõem, para sua existência, uma determinada doutrina, a qual ele chama de "doutrina da diferença". A intolerância existe anteriormente a essas "doutrinas da diferença", porque é definida por Eco como uma predisposição natural que todo ser humano tem, ainda na infância, de rejeitar o que é estranho e lhe desagrada". Ao mesmo tempo, as "doutrinas da diferença" dependem da intolerância, tal como definida pelo autor, porque elas mobilizam intolerâncias difusas existentes na sociedade. Eco (2000: 1719) cita, como exemplo, o antissemitismo. Essa forma de intolerância contra o povo judeu só pode se formar, como uma doutrina e uma teoria, porque já existia uma imagem negativa do judeu ao longo do tempo.

Para o autor, as formas clássicas de intolerância não são as piores, porque podem ser facilmente identificadas e combatidas. A pior forma de intolerância é a que ele identifica como "intolerância selvagem" (2000: 17-19). Essa intolerância extrema está presente no indivíduo e é caracterizada por um ódio descontrolado, irracional e aparentemente sem motivo. A intolerância selvagem não conhece limites nem pode, segundo o autor, ser explicada ou entendida, mas ao mesmo tempo deve ser a principal forma de intolerância a ser combatida.

\footnotetext{
${ }^{50}$ Eco (2000: 17) identifica a educação como uma forma de se diminuir essa tendência natural à rejeição ao que é estranho.
} 
Já a antropóloga Françoise Héritier (2000) procura as causas da intolerância, entendida pela autora como a exclusão e a eliminação de grupos sociais, na rejeição ao outro, a partir de uma ideia de pureza e de unicidade (de qualquer natureza) constituinte da identidade. É a ideia de pureza e de unicidade que orienta as formas que levam ao desaparecimento da figura da alteridade. A definição de Héritier mostra, assim, que o objetivo final da intolerância é eliminar aquilo que supostamente motiva sua própria existência: a alteridade, o outro, a diferença. Como afirma a própria autora:

Um arraigado mecanismo de intolerância e do racismo, inerente à questão da pureza do sangue, consiste na convicção de que os outros não pensam, não sentem, não reagem como nós (qualquer que seja esse 'nós'), que nos consideramos a essência da humanidade e da civilização (2000: 24).

Por isso, para a autora, o outro é sempre transformado em um objeto, ou seja, perde seu estatuto de sujeito, de ser humano. Essa transformação implica uma operação de hierarquização da categoria humana, ou seja, aquele que é visto como outro e como diferente é automaticamente classificado negativamente (ou seja, é considerado de baixo valor em uma determinada "escala social" construída pela própria intolerância). Segundo a autora, "[...] a lógica da diferença não deveria acarretar, automaticamente, nem a hierarquia, nem a desconfiança, nem o ódio, nem a exploração, nem a violência" (Héritier, 2000: 27).

O filósofo Paul Ricoeur, (2000: 20) vai descrever duas características necessárias para a existência da intolerância: a primeira é a reprovação das crenças e convicções do outro; a segunda, o poder ou a capacidade de impedir o outro de exercer e de viver suas convicções e crenças. Há, assim, de um lado, uma interpretação negativa do outro pelos elementos que o constituem e, de outro lado, uma possibilidade de acabar com esses mesmos traços. Sem essa conjugação de elementos (reprovação e capacidade de impedir), é impossível que a intolerância exista. Mas esse é apenas um dos aspectos da intolerância desenvolvido por Ricoeur. O outro aspecto é o da dimensão institucional da intolerância. Por isso, Ricoeur afirma que a intolerância passa a ter uma existência pública a partir do momento em que ela é assumida por um Estado e passa a fazer parte de uma política que impõe, pelo poder que o 
sustenta, uma forma de punição pública baseada em uma "visão particular do bem" (idem). A partir do momento em que essa "visão particular do bem" cede lugar para uma perspectiva mais pluralista, a tendência é que a intolerância também abra espaço para a coexistência de diferentes crenças e convicções (Ricoeur, 2000: 20).

O sociólogo Sérgio Paulo Rouanet (2003: 10) ${ }^{51}$ apresenta a seguinte definição de intolerância: "a intolerância pode ser definida como uma atitude de ódio sistemático e de agressividade irracional com relação a indivíduos e grupos específicos, à sua maneira de ser, ao seu estilo de vida e às suas crenças e convicções" e ainda "a intolerância se caracteriza pela incapacidade de descentramento, de empatia com o ponto de vista do outro". Se um dos traços da intolerância é a "incapacidade de descentramento", consequentemente leva-nos a pensar que outro modo de entendê-la é por meio do forte apego aos valores que definem um indivíduo intolerante (no caso, os valores são aqueles apontados por Héritier: a pureza e a unicidade).

O filósofo e historiador Norberto Bobbio afirma que a tolerância e a intolerância não são completamente idênticas na esfera religiosa e política e na esfera social. Para ele, a tolerância e a intolerância no âmbito religioso e político envolvem a questão da crença e da produção do discurso da verdade. Nas interações sociais, a tolerância e a intolerância relacionam-se com a questão da diferença. Como afirma Bobbio, os defensores da tolerância religiosa ou política se defrontam frequentemente com a seguinte questão: “como são compatíveis, teórica e praticamente, duas verdades opostas?". Já os indivíduos que se manifestam em favor da tolerância nas relações sociais precisam sempre mostrar que um mal-estar gerado pela diferença é fruto de um preconceito ${ }^{52}$ irracional (Bobbio, 1992: 186-187).

Bobbio faz ainda uma espécie de resumo sobre as diferentes perspectivas que a tolerância e a intolerância podem assumir no âmbito do convívio social. Dessa forma, ele propõe que tanto a intolerância como a tolerância vão possuir um traço positivo ou negativo:

\footnotetext{
${ }^{51}$ Contudo, o autor atribui somente à razão o postulado da tolerância. Como se viu em Aurélio (1996), a própria razão se converteu em fonte de intolerância. Além disso, nesta seção se verá que há também um tipo de tolerância não necessariamente associada à razão.

52 Preconceito é, segundo Bobbio, uma opinião errônea (mas considerada verdadeira) acolhida passivamente. Por isso, ela se constitui pela falta de conhecimento e de reflexão (Bobbio, 2002: 103).
} 
- tolerância positiva ${ }^{53}$ : "Entendida desse modo [mal menor ou mal necessário], a tolerância não implica a renúncia à própria convicção firme, mas implica pura e simplesmente a opinião (a ser eventualmente revista em cada oportunidade concreta, de acordo com as circunstâncias e as situações) de que a verdade tem tudo a ganhar quando suporta o erro alheio, já que a perseguição, como a experiência histórica o demonstrou com frequência em vez de esmagá-lo, reforça-o" (Bobbio, 1992: 206);

- intolerância positiva: "severidade, rigor, firmeza, qualidades todas que se incluem no âmbito das virtudes" (Bobbio, 1992: 210);

- tolerância negativa: "indulgência culposa, de condescendência com o mal, com o erro, por falta de princípios, por amor da vida tranquila ou por cegueira diante dos valores" (Bobbio, 1992: 210);

- intolerância negativa: aquela que se fecha em suas certezas, que não se abre para a perspectiva do outro, construindo então uma imagem negativa daquele que não tem as mesmas perspectivas do intolerante.

Tratando dos elementos que caracterizam a intolerância, o antropólogo Harris Memel-Fote (2000) apresenta três temas, com seus respectivos exemplos, considerados por ele indissociáveis na relação entre o "mesmo" e o "outro":

a) quanto ao objeto: o "outro" é sempre o estrangeiro, de nacionalidade, de raça, de etnia, de religião ou de língua. O "mesmo" é o concidadão, o irmão de etnia, o congênere, o correligionário ( $p$. $47)$;

b) quanto aos motivos: o "outro" é sempre o inimigo (nunca o adversário) e, por isso, deve ser eliminado. Quando o "mesmo" passa, por qualquer motivo, a ser partidário dos valores do "outro", é considerado um traidor ou, no mínimo, cúmplice do inimigo;

c) quanto às manifestações, o que predomina é o ódio e o medo: o ódio que motiva a eliminar o "outro" e o medo de ser eliminado pelo outro.

Para 0 autor, essas questões assentam-se em duas categorias imutáveis para o indivíduo intolerante: a identidade exclusiva e a alteridade

\footnotetext{
${ }^{53}$ Veremos, adiante, que a tolerância positiva é dividida em três partes graduais, segundo proposta de Bobbio.
} 
absoluta. É por isso que, para o intolerante, o outro não pode ser aceito em seu grupo, não se pode manter qualquer contato ou relação com o outro e, ainda, o outro deve ser exterminado para se eliminar a ameaça de dissolução da identidade do grupo. Uma resposta a essas categorias absolutizadas, como propõe o autor, seria a identidade e a alteridade relativas, que poderiam produzir "associações e alianças de etnias, de raças, de crenças, até de classes sociais" (Memel-Fote, 2000: 51).

Uma das maneiras de se exemplificar as consequências de uma relação entre a identidade exclusiva e a alteridade absoluta pode ser vista em um trecho de Arkoun. Ele mostra quais são os valores que estão na base de uma postura intolerante: "bem/mal, certo/errado, belo/feio, material/espiritual, mortal/imortal, imanente/transcendente", "histórico/místico, sagrado/profano, religioso/político, Igreja/Estado, espiritual/temporal etc." (Arkoun, 2000: 198199).

Vimos, aqui, algumas características de um indivíduo intolerante. Elas podem ser resumidas pelos seguintes traços: uma identidade exclusiva, com forte apego a valores de unidade e de pureza, rejeita (por ódio ou medo) a presença da alteridade, que deve ser excluída ou, em seu limite, eliminada.

Para tratar da tolerância, começamos com a definição apresentada pela UNESCO, a partir de sua Declaração de Princípios sobre a Tolerância (publicada originalmente em 1995). A Declaração apresenta a seguinte definição de tolerância: a aceitação do pluralismo, isto é, "a harmonia na diferença" que serviria como condição para o desenvolvimento social e econômico dos povos (UNESCO, 1997: 11).

Essa noção de "harmonia na diferença" decorre do conhecimento, da comunicação e da livre expressão de pensamento, de consciência e de crença. Ela deve, segundo a Declaração, ser aplicada aos campos da ética, da justiça e da política por indivíduos, grupos ou Estados com o intuito de substituir uma "cultura de guerra por uma cultura de paz" (UNESCO, 1997: 11).

Essa harmonia não é, como se pode pensar em um primeiro momento, consequência de uma postura passiva. A tolerância é uma atitude ativa baseada no reconhecimento dos direitos universais a que todo homem tem direito. Ao se adotar a tolerância, deve-se, por conseguinte, rejeitar toda forma dogmática para se privilegiar normas construídas por instrumentos regulatórios 
internacionais dos direitos humanos que visam a um caráter universal. Por isso, não é possível tolerar injustiças sociais ou formas de perseguição ao outro. Além disso, a postura tolerante deve aceitar que o outro tenha o direito a escolher a melhor forma de viver (UNESCO, 1997: 11-12).

Podemos ainda acrescentar à "harmonia na diferença" outro elemento. Segundo Héritier, a tolerância caracteriza-se pela fidúcia, em que deve "reinar a confiança e a tolerância em relação ao outro" (Héritier, 2000: 26), já que "todos os humanos sem exceção são definidos como homens" (grifo da autora, 2000: 27). Se considerado esse último postulado, poderíamos, ainda segundo a autora, pensar em uma "hipotética ética universal" (idem).

Monique Canto-Sperber (2000: 90) mostra o vínculo entre "as avaliações morais e a determinação de agir”, ou seja, a relação entre as interpretações e o fazer dos sujeitos. Pode ser considerado bom tolerar algo que se desaprove, mas essa tolerância não pode ultrapassar determinado limite moral, pois seria perigoso tolerar o mal, por exemplo. A autora define, assim, três limites para a tolerância: a) qualquer ato ou comportamento que pode ameaçar a existência da própria tolerância (por essa razão, não pode ser tolerado); b) o que pode ferir a liberdade, os interesses e o direito do outro; c) a existência de certos traços sociais em comum (que, se ultrapassados, suspenderiam a própria existência da tolerância para se fazer justiça) (CantoSperber, 2000: 91-93).

Pode ainda ser acrescentada à interpretação, proposta por CantoSperber, outra forma de interação entre identidade e alteridade. Assim, Bobbio (1992: 206-207) pensa na tolerância como uma estratégia no embate entre sujeitos: "[...] a tolerância é, evidentemente, conscientemente, utilitaristicamente, o resultado de um cálculo e, como tal, nada tem a ver com o problema da verdade". A definição de tolerância é, assim, principalmente de ordem prática. $\mathrm{O}$ autor mostra um bom exemplo de como se pode pensar na tolerância enquanto uma estratégia: se sou o mais forte, a tolerância pode ser uma astúcia; se sou o mais fraco, uma necessidade (até de sobrevivência); se somos iguais, há uma reciprocidade (se eu persigo, posso passar a ser 0 perseguido).

Rouanet (2003: 10), para se opor à intolerância, propõe uma nova postura das pessoas, ultrapassando a tolerância para chegar ao que 
entendemos ser um reconhecimento mais ativo ou mesmo uma solidariedade: "passagem para um estágio mais civilizado e menos mecânico de convívio das diferenças. Penso que as diferenças deveriam conversar entre si, rompendo sempre que possível a camisa-de-força da cultura e da religião". Assim, segundo Rouanet (2003, p. 10), "é preciso passar de uma ética da tolerância, em que as diferenças coexistem, para uma ética do reconhecimento mútuo e da interpenetração".

No entanto, essa posição da tolerância como uma estratégia entre o mais forte e o mais fraco não pode ser tomada como um consenso: como Arkoun (2000) mostra, a tolerância é de certa forma relacionada a uma posição superior do tolerante que, consequentemente, impede um indivíduo que ocupa uma posição social inferior de ser tolerante em relação ao rico, sendo considerado, ao contrário, submisso ou cortês. O autor ainda critica o que ele chama de tolerância ornamental e de tolerância calculada ${ }^{54}$. A primeira é definida como uma tolerância que serve apenas para se criar uma imagem pública apropriada, sem maiores consequências no plano prático. Essa tolerância é exercida, por exemplo, por políticos que procuram melhorar sua imagem para obterem uma popularidade maior (Arkoun, 2000: 201). Ele associa ainda essa forma de tolerância ornamental ao conhecido "politicamente correto", que pode também produzir certos efeitos intolerantes sobre aqueles que não acompanham esse movimento. A segunda forma de tolerância criticada, a calculada, está presente em relações sociais caracterizadas por distintas hierarquias. Dessa forma, essa tolerância está mais próxima de uma forma de compaixão, por exemplo, do rico em relação ao pobre ou do forte em relação ao fraco do que de uma forma mais ativa e justa de tolerância ${ }^{55}$ (idem).

Resumidamente, podemos compreender a tolerância em termos de uma relação entre identidade e alteridade, baseada no reconhecimento de que todo indivíduos possui os mesmos direitos que outros. Além do mais, a tolerância caracteriza-se por haver uma confiança entre identidade e alteridade e uma postura mais ativa, e talvez solidária, da identidade em relação à alteridade.

\footnotetext{
${ }^{54}$ Em alguma medida, a intolerância ornamental e a calculada são também uma crítica indireta à noção de tolerância como estratégia, tal como proposta acima por Bobbio.

${ }^{55}$ Para comprovar a existência dessa forma de tolerância, o autor mostra que, se a relação fosse invertida, não se consideraria o pobre ou o fraco como tolerantes ao rico ou ao forte. Outras formas de se representar essa relação invertida seriam, então, utilizadas: seria o caso de se falar em submissão, respeito ou obediência, entre outras possibilidades (Arkoun, 2000: 201).
} 
Observamos também que a tolerância pode ser usada de modo estratégico e, por vezes, ornamental, sobretudo quando a identidade apresenta uma posição socialmente superior à alteridade. De qualquer forma, o uso da tolerância, nesse último caso, não invalida a busca por uma verdadeira relação harmoniosa e respeitosa entre identidade e alteridade.

Vimos, nesta seção, algumas definições a respeito da intolerância e da tolerância. A seguir, apresentaremos algumas questões relacionadas aos contextos social e cultural necessários para que a tolerância possa efetivamente ser praticada.

\subsection{Público/privado e pluriculturalismo como situações de nascimento da tolerância}

Além dos limites para a atuação da tolerância, enquanto forma de se combater a intolerância e sua existência, há outras maneiras de se pensar nas condições mais apropriadas para o surgimento e fortalecimento da tolerância. Tópicos como as relações entre o público e o privado, as noções de multiculturalismo ou pluriculturalismo podem ser maneiras de se compreender como a sociedade pode também gerar e gerir valores tolerantes, talvez como uma resposta à intolerância difusa mencionada por Eco.

Rouanet propõe, como uma forma de solucionar os conflitos gerados pela intolerância, a distinção clássica entre público e privado: "a democracia moderna não exige a supressão das especificidades de línguas, de religião, de cultura. Ela exige apenas que essas especificidades sejam mantidas na esfera privada e que, como cidadãos, todos os indivíduos obedeçam aos princípios gerais estabelecidos na constituição" (Rouanet, 2003). Em outras palavras, o bem comum e coletivo deve estar acima dos valores individuais e privados, que, por seu turno, não devem sofrer a interferência da dimensão pública. Deve-se, então, ter os limites bem definidos entre o público e o privado para se preservar os direitos individuais contra ingerências públicas e para se evitar uma desigualdade de direitos para grupos sociais distintos. Além disso, os limites de atuação do privado devem também ser geridos e estabelecidos para não se projetarem na esfera pública. Como a noção de público e privado é definida no bojo da civilização ocidental, para aumentar o alcance dessas 
propostas, é preciso ainda verificar como essas noções são compreendidas e vividas nas sociedades orientais.

$\mathrm{Na}$ mesma linha proposta por Rouanet, o sociólogo Dominique Schnapper mostra que as nações democráticas devem articular a seguinte equação entre o público e o privado: identidades específicas no plano privado, mas igualdade e universalidade do princípio público da noção de cidadão. Nas palavras do autor, "a nação democrática tem por princípio e por ambição fazer com que vivam juntos cidadãos iguais enquanto cidadãos, mas também indivíduos portadores de histórias e de culturas específicas" (Schnapper, 2000: 143).

Dessa forma, indivíduos que pertencem a um ou a alguns grupos sociais (por meio de afinidades étnicas, culturais, religiosas, linguísticas etc.) são considerados todos iguais em questões públicas. Em outras palavras, todos os indivíduos, considerados cidadãos no plano público, possuem direitos e deveres que os nivelam sem distinção. Por isso, para o autor, 0 multiculturalismo faz parte do plano privado, no qual a liberdade de escolha deve ser total. Mas o multiculturalismo tem também um limite determinado: ele não pode, em hipótese alguma, ameaçar a existência da universalidade, da igualdade e da unidade do espaço público (ibidem). O autor ainda afirma que as fronteiras entre o público e o privado estão sempre em constante "negociação" e não deve ser apenas obrigação do Estado determinar essas fronteiras, pois se deve contar também com a participação da sociedade nesse processo (Schnapper, 2000: 144-146).

Depois de definir os limites da tolerância, Monica Canto-Sperber elabora dois princípios para a sua aplicação $^{56}$ : a) a neutralidade, como forma de impedir que um modo de vida se torne hegemônico e prejudique a existência de outros modos de vida distintos (esse princípio deve, principalmente, estar presente no Estado, que não deve interferir, dentro da lei, no "estilo" de vida de determinados grupos e, também, não deve privilegiar um determinado modo de vida, ou seja, o Estado deve tratar igualitariamente os grupos sociais); b) o pluralismo, para preservar a multiplicidade e as divergências de opinião e para se combater o processo de homogeneização característico dos Estados

\footnotetext{
${ }^{56}$ Os dois princípios propostos por Canto-Sperber servem justamente para evitar o que Ricoeur chamou mais acima de "visão particular do bem".
} 
modernos (Canto-Sperber, 2000: 94-95). Em outras palavras, deve ser garantida ao indivíduo a sua liberdade de pensamento e de expressão, que, contudo, deve também ser limitada para que não haja tratamento desigual entre os grupos ou os indivíduos, o que poderia produzir a imposição de um ponto de vista único em detrimento da diversidade de opiniões.

Por essa razão, o pluralismo de ideias, de opiniões e de valores deve ser mediado por normas sociais cujo consenso deve sempre ser buscado por meio da discussão e do debate no espaço público. Ao menos essa é a proposta do sociólogo alemão Wolf Lepenies, que acredita que o estabelecimento de uma normatividade consensual pode ser um meio eficaz de combate à intolerância (Lepenies, 2000: 118).

O jurista canadense Irwin Cotler propõe uma espécie de "cidadania planetária", que serviria de base para que o respeito à liberdade de crença seja defendido, mas somente se as religiões não infringirem certos preceitos "universais": "o morticínio, a tortura, a escravidão, o expurgo étnico, a violação e o racismo não podem ser defendidos por nenhuma crença que respeite a humanidade e a religião" (Cotler, 2000: 63).

A imposição de limites, como o de Cotler acima, coloca em evidência a oposição entre universalismo e relativismo. Se o relativismo cultural tem o mérito de eliminar classificações antropológicas hierarquizadas, como as culturas "primitivas" em posição inferior às "civilizadas", quando levado ao seu limite, ele impediria qualquer tipo de tolerância, uma vez que, se tudo fosse válido por causa do que defende um relativismo cultural mais radical, a compreensão de culturas diferentes não seria possível, porque os valores seriam incomensuráveis, ou seja, tudo seria possível e nada teria um aspecto positivo ou negativo (Kawada, 2000: 148-149).

Além disso, grupos minoritários presentes nos países desenvolvidos teriam seu "estilo de vida" aceito pela sociedade majoritária em nome do relativismo cultural, uma vez que a sociedade "respeitaria" (na verdade, suportaria) as especificidades desses grupos (Kawada, 2000: 149). No entanto, essa atitude da sociedade majoritária poderia provocar a manutenção, por exemplo, da pobreza e das precárias condições de vida desses grupos por causa de um "respeito" que é, na verdade, uma passividade implícita que está presente no conceito de relativismo cultural. 
De qualquer forma, é por causa do relativismo cultural que grupos minoritários podem resistir às tentativas de imposição de culturas nacionais e reafirmar suas tradições em outros espaços que não são os de sua origem (Kawada, 2000: 150). É nesse ponto que o relativismo cultural deve ser incentivado para preservar os valores dos grupos minoritários, a partir do que o autor chama de "princípio de não intervenção" ao mesmo tempo em que não se deve transformar o relativismo cultural em um princípio universal (Kawada, 2000: 150). Por isso, Kawada defende também o relativismo cultural em sua dimensão subjetiva:

É bem melhor, sem dúvida, deixar de lado qualquer pretensão ao universal e, sempre que se assumir uma posição, seja qual for a força dessa conviç̧ão, admitir com toda a lucidez seu caráter fundamentalmente subjetivo e empenhar-se sempre na busca de uma subjetividade intercultural de um nível superior (Kawada, 2000: 149).

No entanto, a tomada de posição, a que se refere o antropólogo japonês Junzo Kawada, dentro do relativismo cultural, exige ainda outros cuidados. Reconhecer o direito a toda e qualquer forma de ação ou de opinião, sem qualquer tipo de limite, é apontado pelo dramaturgo Wole Soyinka como uma forma de conciliação e de compromisso que permitiriam o revisionismo de nossos dias (Soyinka, 2000: 132). Se seguíssemos a lógica do relativismo cultural mais radical, opiniões que colocam em dúvida a existência do holocausto ou de qualquer outra forma de extermínio, por exemplo, deveriam ter sua validade reconhecida.

Vimos, nesta seção, que os limites da tolerância, como forma de se evitar o surgimento da intolerância, envolvem sua definição, suas relações entre o público e o privado e a existência de valores relativos em contraposição a valores universais, que regulariam a existência dos primeiros. A seguir, veremos algumas definições que apresentam uma gradação dos conceitos de tolerância e de intolerância para, no final da próxima seção, propor uma síntese desses conceitos. 


\subsection{Quadro da tolerância e da intolerância e suas gradações}

Nesta seção, apresentaremos mais algumas definições dos conceitos de intolerância e de tolerância. Essas definições possuem a peculiaridade de apresentar certa gradação, o que nos permitirá chegar a um denominador comum das diferentes definições vistas até agora. Por isso, retomaremos também algumas das concepções apresentadas para tentar conjugá-las com possíveis gradações da intolerância e da tolerância.

Bobbio (2003: 189-191) apresenta uma gradação da noção de tolerância. A primeira, da qual já falamos, é a considerada um "mal menor", pois ela aceita o erro como forma de se chegar ao caminho da verdade, já que a história da humanidade mostrou, segundo o autor, que o combate violento contra o erro não necessariamente o elimina, mas antes reforça sua existência. A segunda forma de tolerância tem por objetivo a manutenção da convivência civil. Para isso, ela utiliza os mecanismos de persuasão (no lugar da opressão) para convencer o outro de seus erros. A terceira forma defende o respeito à pessoa. Essa tolerância coloca a "moral do respeito" antes da "moral da coerência" (que coloca a verdade acima de tudo).

Para compreender o alcance que a existência do pluralismo de crenças nos dias atuais tem sobre a própria ideia de crença e convicção, Ricoeur (2000: 21-22) apresenta uma gradação do conceito da tolerância nos seguintes moldes: a) "se tolera o que se desaprova mas não se pode impedir" (grifo do autor); b) "vontade de compreender as convicções contrárias, sem, no entanto, aderir a elas"; c) "direito ao erro, associado à ideia de que cada um tem o direito de viver segundo suas convicções" (grifo do autor); d) "parte da verdade pode estar em outro lugar que não nas convicções que fundamentam as tradições em que fomos educados". O autor parte de uma postura passiva (já que se aceita algo que se desaprova, mas cuja existência não é possível impedir) para uma ativa, do desejo de compreender o outro, passando pela questão do direito (universal, a princípio) de todos e das convicções e suas relações com a relatividade da verdade.

O cientista social americano Michael Walzer (1999: 16-17), de modo semelhante a Ricoeur, apresenta também um continuum da tolerância. A primeira, surgida no contexto religioso dos séculos XVI e XVII, refere-se à 
aceitação da diferença para preservar a paz. A segunda, igualmente passiva, é a da indiferença à diferença. A terceira é um reconhecimento dos direitos do outro, mesmo quando esse outro exerce seus direitos de modo desagradável. Por fim, a quarta forma de tolerância está ligada a uma disposição em ouvir o outro. Da mesma forma, Walzer parte de um comportamento mais passivo (da aceitação e da indiferença) para uma atitude mais ativa, que é a do reconhecimento dos direitos de todos e uma disposição para se escutar (e também perceber) o outro.

A prática tolerante deve ser, também para Aurélio, a do reconhecimento do outro. Nesse momento, o autor apresenta uma gradação nas formas de reconhecimento. O autor parte de uma concepção do verbo conhecer, entendido como uma relação entre sujeito e objeto e nada mais do que isso. $O$ conhecer é insuficiente para a tolerância, porque ele está baseado em "normas lógicas" que acabam por apagar o outro. Por isso, ele acrescenta a essa gradação o verbo compreender, no qual a intersubjetividade começa a aparecer, porque passa a ter uma relação simétrica entre o eu e o outro. No entanto, isso ainda não é suficiente para a tolerância almejada pelo autor, porque $\mathrm{o}$ ato de compreender acaba, de alguma forma, deixando de lado alguns traços constitutivos do outro para que esse "eu" possa compreender o outro. Por isso, o reconhecimento, como uma relação mais envolvente entre as duas identidades colocadas em jogo, é a forma de tolerância por excelência para o autor. Dessa forma, reconhecer é reconhecer o lugar do outro, seus valores, suas opiniões e seu estilo de vida (Aurélio, 1996: 217-219).

Com o reconhecimento, não haveria mais a possibilidade de se reduzir a pessoa a um objeto ou a um ato de concessão que exige, como contrapartida, a eliminação de alguns traços constitutivos da alteridade. Com o reconhecimento, haveria a possibilidade de a alteridade apresentar-se de modo completo, sem fraturas ou recortes, para que o eu possa interagir de modo completo. Nas palavras do autor "[...] a razão tolerante fundamentar-se-á, como já dissemos, no reconhecimento do outro enquanto pura alteridade" (Aurélio, 1996: 219-220). E como seu estatuto de alteridade não pode ser reduzido, o outro não pode ser assimilado e deve participar da discussão e da negociação das normas e das regras de convivência entre identidade e alteridade. 
Dessa forma, no reconhecimento, a identidade deve colocar-se no lugar do outro, porque é a partir dessa atitude que se chegará a normas mais justas, decorrentes dessa troca de pontos de vista (Aurélio, 1996: 221). Apesar da impressão inicial do predomínio da subjetividade nesse tipo de tolerância, o autor ainda diz que colocar-se no lugar no outro é também uma atitude pública, uma vez que participam desse ato todas as formas de juízo determinadas coletiva e publicamente (Aurélio, 1996: 222). Dessa forma, a subjetividade é, em alguma medida, condicionada aos valores e aos comportamentos advindos do coletivo.

Apresentamos, a seguir, um quadro com as diferentes gradações dos conceitos de intolerância e tolerância, a partir dos diferentes pontos de vista dos autores citados neste capítulo ${ }^{57}$ :

\begin{tabular}{|c|c|c|}
\hline $\begin{array}{c}\text { Tolerância } \\
\text { ativa }\end{array}$ & $\begin{array}{c}\text { Tolerância } \\
\text { moderada }\end{array}$ & $\begin{array}{c}\text { Tolerância } \\
\text { branda }\end{array}$ \\
\hline $\begin{array}{c}\text { Solidariedade ou } \\
\text { reconhecer }\end{array}$ & $\begin{array}{c}\text { Disposição ou } \\
\text { compreender }\end{array}$ & $\begin{array}{c}\text { Aceitação ou } \\
\text { conhecer }\end{array}$ \\
\hline $\begin{array}{c}\text { Intolerância } \\
\text { ativa }\end{array}$ & $\begin{array}{c}\text { Intolerância } \\
\text { moderada }\end{array}$ & $\begin{array}{c}\text { Intolerância } \\
\text { branda }\end{array}$ \\
\hline Extermínio & Discriminação & Rejeição \\
\hline
\end{tabular}

Cada elemento desse quadro deve ser pensado da seguinte maneira, a partir dos conceitos-chave:

A tolerância branda é um ato que não exige qualquer ação ou esforço do sujeito para aceitar ou conhecer o outro, ou seja, é o movimento inicial para uma aproximação entre os pontos de vista da identidade e da alteridade. A intolerância branda é o estabelecimento de uma distância por meio de uma rejeição à existência do outro. $\mathrm{Na}$ coluna da moderação, há um esforço da identidade em direção a uma compreensão das razões da alteridade, enquanto a intolerância é uma forma de discriminação, na qual a alteridade é socialmente rebaixada. Já na forma plenamente ativa, temos a solidariedade e o

\footnotetext{
${ }^{57}$ Com base na proposta de Bobbio, nos limitamos à tolerância positiva e à intolerância negativa para elaborar o quadro.
} 
reconhecimento (nos termos de Aurélio) como uma forma cuja atividade é mais forte e presente, na qual se exige e se cobra do sujeito uma atitude mais enfática em relação ao outro, à alteridade. Já a intolerância extrema é a forma historicamente mais conhecida: a do extermínio do indivíduo, fazendo-o desaparecer completamente, ou mesmo do genocídio, no caso de a intolerância se estender a uma coletividade.

Por fim, podemos realizar uma síntese comparativa dos pontos de vista dos autores citados, em relação à intolerância e à tolerância:

a) o que é diferente deve ser eliminado, exterminado ou, ao menos, posto à distância para não "contaminar a pureza" do grupo intolerante (Rouanet, Héritier, Eco). Uma forma de se evitar isso está na defesa da tolerância, no espaço público, como uma pauta de princípios de igualdade (discutida pela sociedade), tratando a todos como cidadãos, sem a possibilidade de ingerências no plano privado (em relação a crenças, valores e línguas de indivíduos ou grupos minoritários) (Rouanet, Schnapper, Lepenies, Cotler);

b) na relação com o outro, o intolerante crê em suas certezas e valores, em uma identidade excludente e em uma alteridade absolutizada, elementos que orientam sua interpretação; por isso, tudo o que diverge das convicções do intolerante (e que pertence à alteridade) é considerado negativo e deve ser eliminado, excluído, segregado ou ainda transformado em um objeto (Memel-Fote, Héritier, Canto-Sperber, Arkoun, Cardoso);

c) a intolerância e o preconceito aparecem de forma difusa na sociedade e têm uma origem inata ao próprio indivíduo (Eco);

d) a intolerância e a tolerância podem apresentar diferentes gradações (além de um aspecto positivo e negativo) sem perder, contudo, sua pertinência, seja para combatê-la (no caso da intolerância), seja para praticá-la (a tolerância) (Bobbio, Ricoeur, Aurélio, Arkoun, Walzer);

e) qualquer tentativa de combater a intolerância deve evitar a existência de uma postura intolerante; por isso, deve-se ir além da tolerância e pensar em novas formas de sociabilidade e de respeito à diferença (Rouanet, Aurélio, Canto-Sperber), como o pluralismo do espaço público, a 
relativização das categorias de identidade e alteridade (Memel-Fote, Canto-Sperber, Kawada, Soyinka);

Após a apresentação de um quadro com as gradações dos conceitos de intolerância e de tolerância e de uma síntese com as principais características desses conceitos, veremos, na próxima seção, algumas formas específicas de intolerância na interação entre identidade e alteridade.

\subsection{Três questões particulares da intolerância: racismo, xenofobia e intolerância linguística}

Essa seção apresentará algumas formas de relação entre identidade e alteridade baseadas na intolerância. Tratar-se-á nesta seção do racismo, da xenofobia e da intolerância linguística, questões que interessam mais de perto ao nosso trabalho.

Segundo Santos (1984: 38-41), o racismo é uma doutrina que visa afirmar a superioridade racial de um determinado grupo sobre outros grupos. Essa tentativa de se colocar um grupo como superior a outro leva, por conseguinte, a uma hierarquia social, baseada nos traço raciais, que poderá resultar em um sistema desigual de direitos e deveres no bojo de uma sociedade. Essas características teriam, segundo o autor, sido retrabalhadas no contexto social brasileiro, produzindo, assim, um "racismo à brasileira" dotado de marcas específicas que minimizam os processos de segregação social, chegando até mesmo a serem interiorizados pelos que sofrem os efeitos desse racismo. Esse seria um dos efeitos do mito da democracia racial brasileira.

Existem ainda algumas "variantes" do racismo, cuja definição depende da relação existente entre identidade e alteridade. O racismo simbólico, por exemplo, está presente em percepções (imaginárias ou não) de que os valores da identidade estão sob uma eminente ameaça. Assim, o racismo simbólico elabora uma tentativa de se evitar uma suposta mudança do status quo e passa a representar o outro como uma ameaça a esses valores, de modo intencional, ou seja, o outro premeditadamente visaria à mudança dos valores da identidade ou do status quo para benefício próprio (Lima; Vala, 2004: 404). 
No racismo ambivalente, haveria uma percepção de que a alteridade está em uma posição inferior ou em desvantagem e, por essa razão, seria considerada também uma ameaça aos valores da identidade, porque políticas públicas se voltariam para diminuir essa desvantagem da alteridade. De um modo geral, nesse tipo de racismo, o sentimento não é o de ódio ou de raiva, mas sim o de nervosismo e o de ansiedade que conduziriam a um maior afastamento da identidade em sua relação com a alteridade (Lima; Vala, 2004: 405). O racismo cordial, traço típico brasileiro, tem por característica uma "polidez superficial que reveste atitudes e comportamentos discriminatórios, que se expressam nas relações interpessoais através de piadas, ditos populares e brincadeiras de cunho 'racial'” (Lima; Vala, 2004: 407).

Segundo o Dictionary of Race, Ethnicity and Culture, a xenofobia está, quase sempre, associada a alguma forma de racismo, sendo muitas vezes difícil fazer uma distinção desses dois conceitos. No entanto, a xenofobia apresenta algumas especificidades. Segundo o mesmo dicionário, a xenofobia surge do medo de se perder a identidade por causa da presença da alteridade, mais exatamente do estrangeiro. Dessa forma, o estrangeiro é visto como um invasor ou um inimigo ou, em outras palavras, como aquele que veio de fora para ameaçar a estabilidade (de emprego, de valores, de comportamento, de religião etc.) que a identidade acredita ter. Dessa forma, a xenofobia pode ser entendida como uma reação de defesa, individual ou coletiva, que visa à preservação de sua nacionalidade e dos valores que a sustentam (Bolaffi et al., 2003: 330-332).

Trataremos, a partir daqui, de uma forma particular de intolerância, cuja especificidade é a de ser pouco percebida como intolerância e/ou preconceito. Referimo-nos à intolerância e ao preconceito linguísticos. Inicialmente, precisamos distinguir o preconceito da intolerância linguística. Marli Quadros Leite (2008) apresenta a seguinte distinção:

O preconceito é a discriminação silenciosa e sorrateira que o indivíduo pode ter em relação à linguagem do outro: é um não-gostar, um achar-feio ou acharerrado um uso (ou uma língua), sem a discussão do contrário, daquilo que poderia configurar o que viesse a ser o bonito ou correto. É um não-gostar sem ação discursiva clara sobre o fato rejeitado. A intolerância, ao contrário, é ruidosa, explícita, porque, necessariamente, se manifesta por um discurso metalinguístico, calcado em dicotomias, em contrários, como, por exemplo, 
tradição $x$ modernidade, $x$ conhecimento $x$ ignorância, saber $x$ não-saber, e outras congêneres (grifos da autora, Leite, 2008: 24-25).

Dessa forma, o preconceito linguístico está relacionado a uma imagem negativa formada, a partir da definição dada por Bobbio ao preconceito, por uma opinião errônea adquirida sem reflexão. Já a intolerância linguística apresenta uma formulação mais elaborada a partir do momento em que estabelece oposições que vão rebaixar ou, em seu limite, excluir determinado indivíduo que não se adapta a um determinado padrão linguístico imposto.

A intolerância linguística pode estar presente nos seguintes planos: 1) institucional, que envolve as "políticas linguísticas" institucionais como, por exemplo, na proibição do uso de línguas estrangeiras no espaço público (como ocorrera no governo de Getúlio Vargas) ou no uso de termos estrangeiros (como foi o caso da lei Aldo Rabelo); 2) social, relacionada aos diversos tipos de avaliações realizadas sobre o falar do imigrante, tanto em relação à sua língua de origem quanto ao seu sotaque, quando utiliza a língua portuguesa.

Vamos nos restringir ao segundo caso. A intolerância e o preconceito podem ocorrer de duas formas distintas quanto ao objeto visado: uma externa, por avaliar negativamente determinados idiomas estrangeiros, e uma interna, cuja avaliação negativa recai sobre as variantes desprestigiadas da língua portuguesa. Em relação aos imigrantes, essas duas formas de intolerância e de preconceito linguísticos podem coexistir, pois se pode avaliar de forma negativa o uso de determinado idioma estrangeiro em solo brasileiro ou ainda o uso do português pelos imigrantes (Barros, 2004: 4-5). É possível, assim, compreender a intolerância linguística como um fenômeno de discriminação que está diretamente associado às representações da língua e às representações dos usuários de determinadas normas linguísticas.

A representação positiva ou negativa de determinada língua está diretamente relacionada à valorização ou à desvalorização de determinados países estrangeiros. Uma língua estrangeira pode, assim, ser mais bem vista e valorizada em relação à língua nacional (como no caso do inglês e, em menor medida, o francês), assim como outra língua estrangeira pode não gozar do mesmo prestígio perante a sociedade, a depender da imagem que se tem dos países estrangeiros. As línguas desprestigiadas em relação à língua nacional no Brasil são, por exemplo, as línguas africanas, indígenas ou asiáticas, neste 
último caso principalmente de países cujas imagens remetem a uma avaliação negativa (como a China, até pouco tempo atrás).

As imagens das diferentes regiões do país e das diferentes classes sociais influenciam nas avaliações das diferentes variantes da língua portuguesa falada no Brasil. Por exemplo, a variante nordestina tem menos prestígio, na região Sul e Sudeste do Brasil, do que a variante carioca ou gaúcha. As críticas em relação ao modo de falar de certos indivíduos, que se "desviam" de um padrão previamente determinado, pressupõem interpretações e avaliações que homologam a variação linguística e a posição social ocupada pelos falantes "julgados" (Lucchesi, 2000: 64). Dessa forma, pode existir uma sobredeterminação que relaciona variante e região, mesmo no caso dos imigrantes e, sobretudo, dos filhos dos imigrantes ${ }^{58}$.

Sumariando esta seção, podemos afirmar o seguinte: a intolerância linguística ocorre em relação às variantes desprestigiadas e em relação a determinadas línguas estrangeiras com a participação de elementos extralinguísticos, como a classe social ou a imagem que um país estrangeiro tem na sociedade brasileira. Quanto aos imigrantes, a intolerância linguística da sociedade e do Estado brasileiros ocorre tanto no uso de suas línguas de origem (as línguas estrangeiras) como no sotaque presente nos usos que eles fazem da língua portuguesa.

O fenômeno da intolerância linguística deve ser entendido, então, como um problema linguístico, social e ideológico, gerado a partir de uma idealização das formas linguísticas que se transforma em parâmetro de julgamento em relação àqueles que não seguem os padrões normativos (sejam brasileiros de estratos sociais mais baixos, sejam estrangeiros). Assim, a hierarquização social homologa-se a uma hierarquização linguística: aqueles que não utilizam a norma linguística estabelecida socialmente são considerados, quase automaticamente, inferiores, inadequados, ignorantes, estranhos, excêntricos, entre outros ${ }^{59}$.

\footnotetext{
${ }^{58}$ Por exemplo, um descendente de japonês, a despeito da imagem positiva que existe para o descendente dessa origem, que resida ou residiu na região Norte ou Nordeste do Brasil, adquiriu a variante fonética daquela região e, assim, poderia enfrentar discriminações por conta de seu "sotaque", principalmente se estivesse residindo em outra região do país.

${ }^{59}$ Segundo Barros (2008), o discurso intolerante apresenta duas realizações distintas, a partir de uma hierarquização que ele estabelece. Há discursos com uma intolerância primária e uma intolerância secundária. O discurso intolerante pode, assim, apresentar sua intolerância primária (como os discursos
} 
A partir dos elementos apresentados neste capítulo, passaremos, a seguir, à nossa proposta de organização das noções de tolerância, intolerância e preconceito, entendidas como a base para determinadas paixões e formas de interação sob a ótica da semiótica de linha francesa.

racistas, xenófobos, etc.) de forma explícita ou apresentar uma intolerância secundária que serve para camuflar a intolerância primária porque é, entre outros motivos, mais bem aceita socialmente. Como a própria autora mostra, é o caso de discursos que avaliam negativamente a fala dos negros para não explicitar o racismo de base (Barros, 2008: 342). No capítulo seguinte, retomaremos essas ideias para desenvolvermos nossas reflexões a partir de uma perspectiva discursiva, tal como a autora apresenta. 


\section{Princípios teóricos: elementos para análise da interação entre identidade e alteridade no espaço social brasileiro}

\subsection{Introdução}

Este capítulo começa com uma questão muito simples em relação à intolerância. E essa questão surgiu a partir do seguinte comentário de Elie Wiesel: "A intolerância é mais complicada, porque mais sutil. Onde reconhecêla? Como discerni-la?" (Wiesel, 2000: 8).

A questão então é: como reconhecer a intolerância? Como percebê-la diante de uma infinidade de comportamentos, práticas e discursos? Uma possível resposta pode ser encontrada a partir do exame de sua organização subjacente, ou seja, significa dizer que a intolerância, enquanto um sentido estruturado, pode ser reconhecida como tal, porque ela é dotada de elementos invariantes que a caracterizam. Evidentemente, o mesmo pode ser dito a respeito da tolerância.

A análise de discursos intolerantes, sob o prisma da semiótica, deve examinar os seguintes elementos: a organização dos valores construídos pelo discurso no nível fundamental e tensivo; o esquema narrativo e, principalmente, os esquemas de manipulação (estabelecimento do contrato entre destinador e destinatário) e de sanção (julgamento do destinador sobre o /fazer/ e o /ser/ do sujeito); as organizações passionais presentes no nível narrativo e discursivo (enunciação passional); a organização modal no nível narrativo e a aspectualização no nível discursivo; exame das categorias enunciativas de pessoa, de tempo e de espaço; as relações entre enunciador e enunciatário; o uso de temas e figuras; e a interdiscursividade, ou seja, qual o tipo de relação que um discurso intolerante mantém com outros discursos sociais (Barros, 2007: 02).

Pretendemos desenvolver nossas reflexões acerca da noção de intolerância e de tolerância da seguinte maneira: tomando o contínuo como ponto de partida para a formação dos valores, entendemos que eles orientarão as interações entre sociedade nacional, Estado brasileiro e imigrantes. Além dos valores, essa interação vai envolver também diferentes estados passionais que contribuirão para a construção da autoimagem da identidade e as 
representações da alteridade. Podemos, então, dizer que a intolerância e a tolerância envolvem valores e paixões na construção de simulacros que vão determinar o modo de relação entre a identidade e a alteridade.

Estamos conscientes dos riscos que toda assunção traz no campo teórico. Assumimos, assim, a possibilidade de desagradar a "gregos e troianos", praticantes de uma semiótica que hoje se encontra, enquanto campo teórico, cada vez mais difusa e que com isso perdeu certa inocência relacionada a uma ideia de completa homogeneidade de seu quadro conceitual. De qualquer maneira, nossa postura teórica não é a de um provocador, mas a de um sujeito que visa, sobretudo, a pensar a semiótica a partir das questões suscitadas pelo(s) seu(s) objeto(s) de análise, mais do que por uma fidelidade (ou mesmo crença) teórica. A postura ora adotada parecenos permitir, se não maior liberdade, ao menos flexibilidade teórica diante de nossos objetos de interesse.

É justamente por apresentar atualmente grande número de caminhos distintos que não vamos realizar uma apresentação geral da teoria ${ }^{60}$ (mesmo porque ela seria insuficiente para mostrar os rumos atuais da semiótica ${ }^{61}$ ). Veremos apenas como os valores são formados no discurso sobre a imigração (focando nas questões suscitadas pela tolerância e pela intolerância) e quais os modos de um sujeito se relacionar com esses valores. Em seguida, desenvolveremos como esses valores podem ser pensados na interação e, por fim, mostraremos a organização passional presente nos discursos sobre a imigração e os imigrantes.

Antes de tratarmos dessas questões, apresentamos a seguir uma proposta de tipologia do discurso sobre a imigração como forma de se tentar organizar a totalidade discursiva desse campo.

\footnotetext{
${ }^{60}$ Não descreveremos em pormenores todos os conceitos da teoria semiótica neste capítulo. Em nossas análises, procuraremos explicar as definições de cada conceito, sempre que necessário. Remetemos ainda o leitor para as seguintes obras introdutórias: Barros (1988), Fiorin (1994), Bertrand (2003) e Fontanille (2008).

${ }^{61}$ Para isso, indicamos o texto de Barros (2007b) para um maior esclarecimento dos rumos tomados na atualidade pela semiótica de linha francesa.
} 


\subsection{Tipologia do discurso sobre a imigração}

Falar sobre o imigrante é colocar em discurso uma alteridade que fica a meio caminho de ser um objeto ou um sujeito. Isso ocorre porque o imigrante é, ao mesmo tempo, ator e tema de um discurso. Se o Outro de um discurso não apresenta uma completa passividade, característica de um objeto, o agir, o pensar e o sentir da alteridade são construídos e delimitados por um enunciador que precisa refrear a própria dinâmica da alteridade para delimitar os seus contornos (representação) e, assim, poder definir sua própria identidade. É ainda por meio desses discursos que se torna possível examinar o modo como uma sociedade constrói sua própria imagem, seus valores e seus estilos de vida.

Os discursos sobre a imigração e os imigrantes possuem uma variedade de temas e de figurativizações. Eles podem tratar da imigração de um modo geral ou de um indivíduo que tenha feito algo considerado digno de destaque ou dado sua singela contribuição para o país e para a sociedade. Além disso, esses discursos tratam também do trabalhador imigrante, do estudante vindo junto com seus pais, dos artistas estrangeiros que passam a morar no Brasil, entre outras possibilidades.

A totalidade desses discursos pode ser organizada de forma a estabelecer uma tipologia dos discursos sobre a imigração, clarificando a organização desse universo discursivo que gira em torno dessa peculiar figura da alteridade.

Dessa maneira, tomando emprestadas as noções de totalidade e unidade, partitiva e integral, desenvolvida por Greimas e Landowski (1981) e posteriormente retomadas em um trabalho de Denis Bertrand (2007), propomos a seguinte tipologia dos discursos sobre a imigração: 
Unidade integral (pessoa individual) Indivíduo imigrante

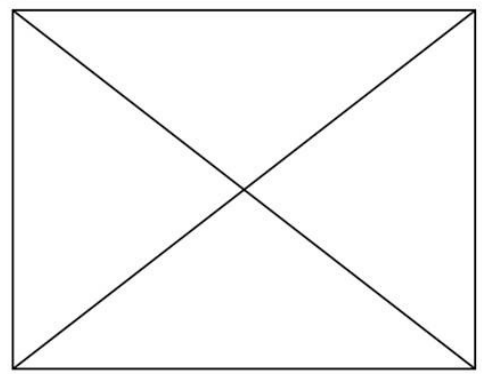

Totalidade partitiva (coletividade temática) Família de imigrantes, associações imigrantes, escolas da comunidade imigrante, etc.
Totalidade integral (coletividade individualizada)

A imigração (...), os imigrantes (...)
Unidade partitiva (papel temático)

Trabalhador imigrante, aluno imigrante, comerciante imigrante,

etc.

A unidade integral está na base dos discursos que tratam do indivíduo imigrante. Esses discursos constroem geralmente a história pessoal desse indivíduo. O mais frequente é ocorrer a debreagem interna (dar a palavra ao imigrante). A partir daí, o discurso do imigrante toma a forma de um percurso no qual ele conta suas motivações para vir ao Brasil, suas impressões, expectativas e quais os modos usados para superar diversos obstáculos postos em sua vida. Além disso, em geral, o imigrante menciona sua relação com o Brasil e a imagem que ele possui dos brasileiros. Há, por fim, um predomínio forte da figurativização e da iconização dos atores nesse tipo de discurso:

Em agosto do ano passado, o boliviano Edgar Guzman Huanca, na época com nove anos, estava indo muito bem na escola e já falava português melhor do que os pais, que haviam trocado a Bolívia por São Paulo em 1990. Hoje Edgar não aprende nem fala português, pois foi obrigado a voltar para a Bolívia e viver longe da família após ter sido expulso da escola onde estudava (Jornal Zero Hora, 1․ de setembro de 1994: 40) ${ }^{62}$.

À noitinha, a fome apertou e Kudama desceu para comprar pão. Antes de voltar, todavia, o trem partiu, levando os desesperados Yassuda e Nagasi, que choravam com pena do amigo. Kudama também chorou muito, até que resolveu dormir num banco da praça da República, onde ficou até à hora do fechamento dos portões (Pagote e Moraes, 1958: 22).

\footnotetext{
${ }^{62}$ Colocamos, como exemplo, trechos de textos que serão objeto de análise de nosso trabalho.
} 
Do lado da unidade partitiva, a presença da figurativização continua presente, mas sem a iconização do tipo discursivo anterior. Esse discurso trata da imigração e do imigrante de uma maneira "mais ampla", construindo um determinado papel temático para desenvolver sua isotopia. Esse percurso temático e figurativo, por vezes, pode resvalar na estereotipia e na cristalização de determinadas imagens associadas à imigração. Esse é o caso dos discursos que associam a ideia de que judeus são ótimos comerciantes, os japoneses são estudiosos e os italianos e os espanhóis, trabalhadores incansáveis, entre outros percursos:

\begin{abstract}
Os vestibulandos costumam dizer que não passa de brincadeira a ideia de que os estudantes de origem asiática conquistam mais vagas nas melhores universidades. Mas o mito pode causar ainda mais expectativa em quem já está bastante preocupado com a concorrência no vestibular (Folha de S. Paulo, 05 de setembro de 2002: Página especial 3).
\end{abstract}

Na totalidade integral, os discursos circunscrevem-se a um único grupo, como a imigração japonesa, alemã, italiana, espanhola etc. ou simplesmente referem-se à imigração ou aos imigrantes, de forma genérica. Esses discursos poderiam ser também chamados de "as grandes narrativas", pois trabalham os traços mais gerais da história da imigração de um determinado grupo:

Para impedir que elementos estrangeiros no Brasil venham perturbar a nossa soberania ou serem fatores dissociativos ou enfraquecedores do espírito da nacionalidade é preciso cuidar-se da assimilação do alienígena e de seus descendentes. Daí decorre a necessidade imprescindível de associar-se ao problema imigratório o de assimilação (Côrtes, 1947: 6).

Por fim, a totalidade partitiva trata de uma coletividade temática: a família, a escola, a comunidade, a associação, o hospital, o clube etc. voltados para os imigrantes. Esse tipo de discurso se refere a coletividades menores e a atividades específicas de determinado grupo imigrante:

O papel da família na educação nipônica é muito importante, e à total autoridade paterna cabe formar o espírito de disciplina e obediência nos mais jovens. Esta parte da educação foi e é cumprida pelos 'issei', e para complementá-la apareceram as escolas japonesas, com professores, currículos e programas iguais aos do curso primário japonês. Antes da guerra essas escolas funcionavam abertamente, com seus 6 anos de ensino, tanto em zonas 
rurais como urbanas, onde houvesse um número de japoneses suficiente para mantê-las (Cardoso, 1959: 103-104).

Evidentemente, diante da complexidade constitutiva dos discursos, muitas vezes é possível observar uma mistura de tipos, mas sempre com o predomínio de um sobre os demais. Essa tipologia, contudo, não é suficiente para explicar como se estabelecem as relações entre imigrantes e a sociedade e o Estado brasileiros nem as imagens produzidas nessas relações. A interação entre identidade e alteridade será explicada de outra forma. Como veremos a seguir, o princípio que servirá de base para a interação será a formação dos valores.

\subsection{A formação dos valores no discurso (in)tolerante}

Para se compreender como um discurso intolerante se configura, é preciso observar quais os valores que ele constrói e, acima de tudo, a forma como o sujeito intolerante relaciona-se com esses valores.

Entende-se, para este trabalho, que muitos dos elementos acima elencados por Barros "sofrem" influência dos valores formados no nível mais profundo do percurso gerativo do sentido. Dessa forma, este trabalho se desenvolverá sob a seguinte perspectiva: por serem os valores objeto de disputas, defesas, substituições, desejos e estilos de vida distintos, eles são essenciais às configurações narrativa e discursiva em um discurso intolerante. Retomaremos algumas reflexões acerca dos conceitos de tolerância e intolerância apresentados no capítulo anterior, para tentar adequá-los ao quadro metodológico e analítico da semiótica discursiva francesa.

$O$ valor era concebido inicialmente pela semiótica como uma rede de diferenças entre os termos que a constitui e é representada por meio do quadrado semiótico. Esse valor passa a ser considerado uma axiologia a partir do momento em que a foria é projetada sobre o quadrado, sendo um dos eixos considerado positivo/eufórico enquanto o outro é, por consequência, negativo/disfórico. Depois da foria, os termos constitutivos do quadrado são projetados para o nível narrativo na forma de objeto-valor.

Nesse nível, os valores podem ser descritivos ("objetos consumíveis e entesouráveis, prazeres e 'estados de alma' etc.") ou modais (querer, poder, 
dever, saber fazer/ser). Os valores descritivos podem ainda ser divididos em valores subjetivos (geralmente manifestados pelo verbo 'ser') e valores objetivos (geralmente manifestados pelo verbo 'ter' ou seus parassinônimos). Além disso, os valores podem ser considerados de base - quando se encontram no programa narrativo principal - ou de uso, por meio de programas narrativos secundários que servem para se chegar ao programa principal.

É preciso, ainda, observar a circulação e os modos de adquirir ou perder os objetos-valor. Barros (1988: 33) apresenta, a partir de Greimas, do lado do programa de aquisição, a doação (quando há uma conjunção em que o sujeito do fazer é diferente do sujeito de estado) e a apropriação (quando há conjunção e o sujeito do fazer e do estado são os mesmos). No programa da privação, a espoliação ocorre quando há uma disjunção em que o sujeito do fazer é diferente do sujeito de estado, e a renúncia, quando existe a disjunção, e o sujeito do fazer e de estado são os mesmos. No caso específico da troca, o Dicionário de Semiótica ressalta que "tal operação [a troca] implica, no caso de os valores não serem idênticos, sua avaliação prévia; estabelece-se assim um contrato fiduciário entre os sujeitos que participam da troca, contrato que fixa o valor dos valores em jogo" (Greimas \& Courtés, s/d: 482-484).

Vemos que a definição de Bobbio para o problema da intolerância e da tolerância repousa sobre um par mínimo (intolerância vs. tolerância) que pode apresentar tanto uma dimensão eufórica como disfórica. Contudo, não é possível pensar nas definições de Bobbio apenas em termos positivos ou negativos, uma vez que suas definições não levam apenas a uma negação ou oposição de um termo para se definir outro. Como o próprio autor nos mostra, se a tolerância positiva é uma forma de aceitação da presença da alteridade, ela não necessariamente leva a uma negação dos valores do próprio individuo tolerante, ao contrário da tolerância negativa, cuja base está na aceitação completa de qualquer erro, violência ou agressão. Da mesma forma, uma intolerância positiva está ligada a uma postura forte, mas não absoluta, em relação aos valores nos quais se acredita. Ela está, assim, mais ligada a uma convicção do que a uma tentativa de impor seu próprio ponto de vista, que é uma das características da intolerância negativa. Para tentar equacionar essas questões, podemos recorrer ao quadrado proposto por Zilberberg (apud Barros, 1988: 25-26), relacionado à tensão e ao relaxamento do sujeito: 

Intolerância negativa
(tensão)
Tolerância negativa
(relaxamento)

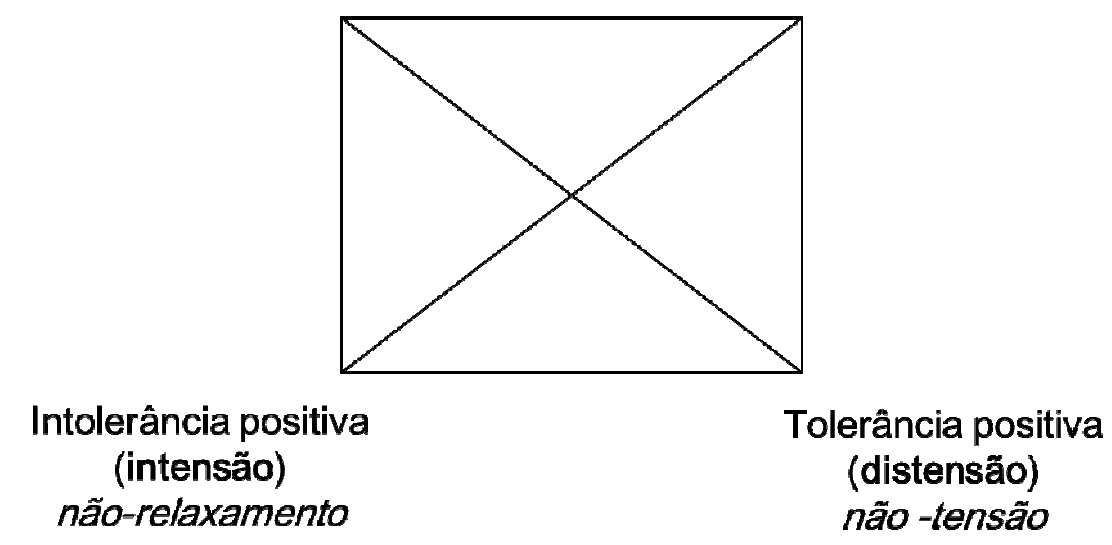

Contudo, esse quadrado, apesar de poder servir de base para uma tipologia dos corpos nos discursos intolerantes e tolerantes, não compreende as gradações possíveis dentro de cada termo, ao menos da maneira que foi apresentada na parte final do capítulo anterior. Por isso, nos deteremos no estabelecimento das gradações referentes à intolerância negativa e à tolerância positiva, cientes de que um maior aprofundamento poderia levar a uma gradação igualmente produtiva dos dois outros termos cujo desenvolvimento será deixado de lado. De qualquer maneira, veremos abaixo como podemos recorrer às noções de tensão e de relaxamento para associálos às diferentes formas de intolerância e de tolerância propostas.

Para responder à questão da gradação da intolerância e da tolerância, recorremos à proposta encontrada no livro Tensão e Significação (2001), de Fontanille e Zilberberg. Vamos, então, apresentar resumidamente como os valores são formados a partir dos postulados teóricos da semiótica tensiva.

A intensidade e a extensidade são a condição primeira para a articulação do valor enquanto sentido. O sentido articulado é, assim, gerado por meio da correlação entre intensidade e extensidade. Essa correlação pode ocorrer de duas formas: a conversa e a inversa. A definição de cada correlação parte de duas articulações básicas: "e... e..." (conjunção) e "ou... ou..." (disjunção) (Fontanille e Zilberberg, 2001: 26). A disjunção e a conjunção definem, respectivamente, os operadores da triagem e da mistura que estão no 
eixo da extensidade. No eixo da intensidade, encontramos os operadores de tonicidade e de atonicidade. Dessa forma, a correlação conversa (em que predomina a mistura) gera o regime participativo enquanto a correlação inversa (cujo predomínio é da triagem) produz o regime exclusivo ou de exclusão (Fontanille e Zilberberg, 2001: 26-27).

Nos valores orientados pela triagem, há uma restrição na circulação entre os objetos, enquanto nos valores orientados pela mistura, a circulação dos objetos tem um espaço maior e mais aberto (Fontanille e Zilberberg, 2001: 27). Os valores gerados pela correlação entre triagem e mistura, tonicidade e atonicidade são os seguintes:

\begin{tabular}{|l|c|c|}
\cline { 2 - 3 } \multicolumn{1}{c|}{} & Triagem & Mistura \\
\hline Tônica & Unidade/nulidade & Universalidade \\
\hline Átona & Totalidade & Diversidade \\
\hline
\end{tabular}

(Fontanille e Zilberberg, 2001: 33)

Os quatro valores do quadro acima são igualmente explicados por Fontanille e Zilberberg. Assim, a unidade/nulidade refere-se a uma única ocorrência de um determinado elemento. A unidade pode ser entendida como um valor da pureza, gerada pelo regime de exclusão (triagem). Na totalidade, há também uma exclusão (uma vez que ela é formada pela triagem), mas uma exclusão com um mínimo de esforço. Assim, a existência desse valor implica a exclusão de alguns elementos, mas não de todos.

A explicação da universidade e da diversidade apresentada por Fontanille e Zilberberg será citada, porque ela apresenta elementos que podem nos ajudar a pensar na organização da tolerância:

Numa semiótica da mistura, o excesso permite, em nome da "tolerância", da "abertura", do tão justamente denominado "pluralismo", passar da "diversidade" à "universalidade"; o acento se desloca da diferença (a desigualdade, nesse caso) para a semelhança (a igualdade); a falta, que restabelece a "diversidade" em detrimento da "universalidade", entre em ação assim que decai o fervor das confraternizações entusiastas, o que, como cada um pode sentir, é uma questão de tempo: o "ápice" não suporta a duração (Fontanille e Zilberberg, 2001: 34). 
A partir das explicações acima sobre a formação dos valores, vamos retomar o que alguns autores falaram sobre a intolerância e a tolerância. Tomamos, assim, a definição de dois autores que podem nos ajudar mais do que os outros para essa parte do trabalho. Começamos, então, com as definições de Umberto Eco e Françoise Héritier:

\begin{abstract}
"A intolerância mais perigosa é sempre aquela que, na ausência de qualquer doutrina, nasce dos impulsos elementares; por isso é que ela é difícil de ser identificada e combatida com a ajuda de argumentos racionais" (Eco, 2000: 18).

"Em suas formas mais evidentes - a exclusão ou o aniquilamento de grupos inteiros -, a intolerância é sempre, essencialmente, a expressão de uma vontade de assegurar a coesão daquilo que é considerado como que saído de $\mathrm{Si}$, idêntico a Si, que destrói tudo o que se opõe a essa proeminência absoluta" (Héritier, 2000: 24).
\end{abstract}

Umberto Eco reflete sobre o que ele chama de intolerância selvagem. Essa intolerância é desprovida de qualquer doutrina que a justifique. Consideramos, então, essa forma de intolerância como uma forma que ultrapassa a triagem tônica para chegar efetivamente aos valores de absoluto, o que explicaria a noção de aniquilamento mencionado no texto de Héritier. A outra intolerância, a baseada em uma doutrina, é em nossa proposta uma forma tônica de triagem. Essa segunda forma de intolerância é, principalmente, a de que fala Françoise Héritier (exclusão).

Ao contrário das duas outras formas de intolerância, que são tônicas, propomos uma terceira forma de intolerância, cuja existência está igualmente ligada ao operador triagem, mas orientada por uma atonicidade. Por isso, não produz um discurso de eliminação ou de exclusão, mas sim um discurso de segregação. Por ser uma forma que distancia a alteridade da identidade, consideramos que essa terceira forma de intolerância é mais bem compreendida se a considerarmos como uma intolerância velada.

Podemos representar, assim, em um esquema tensivo, a organização da intolerância: 


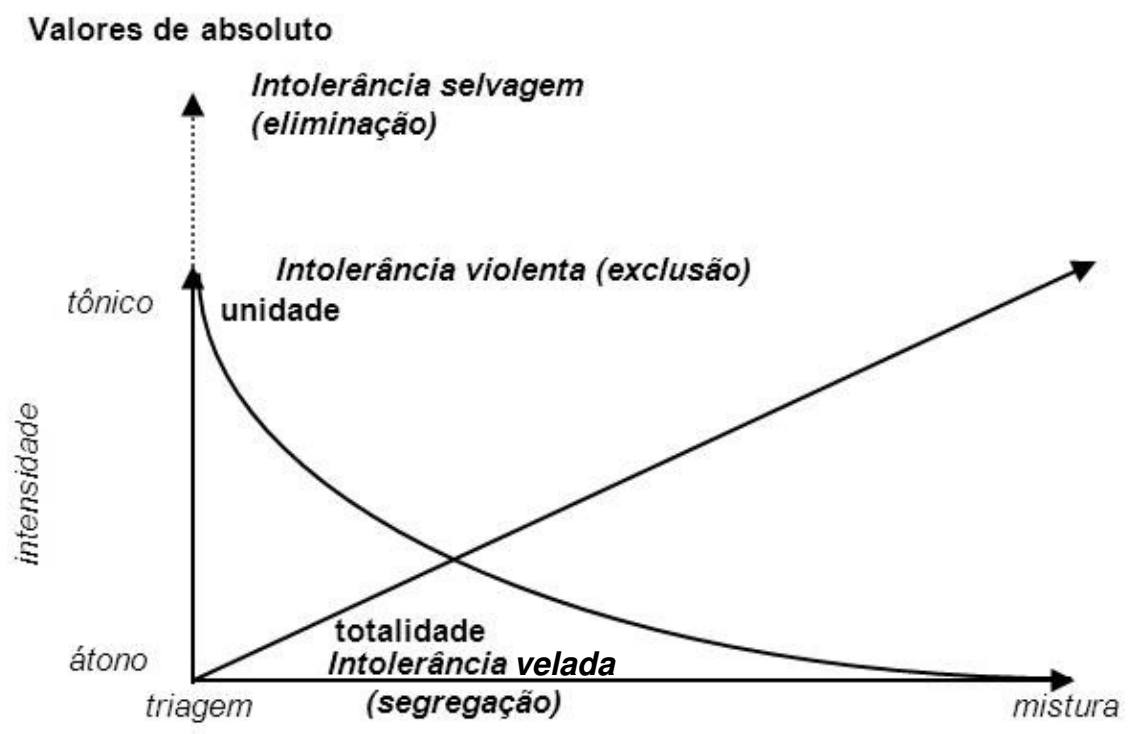

extensidade

A partir desse esquema, podemos observar que a intolerância selvagem está baseada nos valores de absoluto. Dessa forma, a restrição na circulação de valores chega ao seu limite simplesmente, porque não há mais circulação de valor algum, apenas a presença do valor de "pureza" ou "homogeneidade". Da mesma forma, o sujeito intolerante que aderir a esses valores é aquele que visa à eliminação do outro, da alteridade, porque crê de forma absoluta nos valores que 0 definem ${ }^{63}$. Assim, não existe espaço para a presença da alteridade. Quando ocorre a efetiva diminuição da intensidade, passa-se à intolerância violenta cujo sujeito se baseia, no nível narrativo, na exclusão (para a construção de uma unidade) e não na eliminação da alteridade. A outra forma de intolerância, que possui uma triagem átona, vai gerar a segregação (que se reflete na elaboração da totalidade).

O sujeito intolerante promove as operações de triagem que geram diferentes graus de disjunções (eliminação, exclusão, segregação) em relação à alteridade. As diferentes formas de intolerância podem ser entendidas da seguinte maneira: a intolerância selvagem é a forma mais forte de disjunção, pois é produzida por uma triagem a mais radical possível que não aceita nenhuma forma de alteridade e, por isso, procura apagá-la completamente de

\footnotetext{
${ }^{63}$ Como afirmam Zilberberg e Fontanille: "A lógica da triagem pode, pois, chegar ao niilismo integral. Lembremos, de passagem, que os grandes ensaios sobre o fenômeno totalitário contemporâneo demonstraram amplamente que o fundo, ou a forma acabada, do totalitarismo era o niilismo;" (2001: 33).
} 
seu horizonte de possibilidades (por exemplo, quando alguém é assassinado por ser homossexual, negro, morador de rua etc.).

A segunda forma de intolerância, a violenta, parte para a exclusão do outro, porque esse outro não pode permanecer no campo de presença do sujeito intolerante. Por isso, deve ser excluído, mas não exatamente eliminado (ou seja, não se mata o outro). Em outras palavras, a intolerância violenta pode ser entendida como uma forma de se separar a identidade da alteridade e uma maneira de se evitar que ambas vivam no mesmo espaço.

Já a terceira forma de intolerância, que podemos também classificá-la de intolerância velada, concebe a existência da alteridade, como uma forma de vida que não pode e não deve se misturar com os traços e elementos que constituem a identidade. Por essa razão, a alteridade deve ser mantida a uma "boa distância" da identidade para não contaminá-la ou mesmo ameaçá-la. Podemos observar, sobretudo nas duas primeiras formas de intolerância, que o sujeito intolerante concebe tanto a identidade quanto a alteridade como elementos absolutos (como postulado por Memel-Fote). Isso significa, em um plano mais prático, que ambas, identidade e alteridade, não têm condições de se misturar, de se relacionar e mesmo de coexistir em um mesmo espaço.

No nível discursivo, cada um desses valores vai gerar determinados temas, como propomos no seguinte quadro:

\begin{tabular}{|c|c|c|c|}
\hline $\begin{array}{l}\text { Formas de } \\
\text { intolerância } \\
\text { (valores) }\end{array}$ & $\begin{array}{c}\text { Intolerância } \\
\text { selvagem (valores } \\
\text { de absoluto) } \\
\text { (nulidade) }\end{array}$ & $\begin{array}{c}\text { Intolerância } \\
\text { violenta (triagem } \\
\text { tônica) } \\
\text { (unidade) }\end{array}$ & $\begin{array}{c}\text { Intolerância átona } \\
\text { (triagem átona) } \\
\text { (totalidade) }\end{array}$ \\
\hline Operação & $\begin{array}{c}\text { Eliminação do } \\
\text { outro }\end{array}$ & $\begin{array}{c}\text { Exclusão do } \\
\text { outro }\end{array}$ & Segregação do outro \\
\hline Temas & $\begin{array}{c}\text { Holocausto, } \\
\text { massacres, } \\
\text { assassinatos etc. }\end{array}$ & $\begin{array}{l}\text { Racismo, } \\
\text { xenofobia, } \\
\text { intolerância } \\
\text { religiosa, } \\
\text { linguística etc. }\end{array}$ & $\begin{array}{c}\text { Discriminação motivada } \\
\text { pela origem, pela } \\
\text { aparência, pela religião, } \\
\text { pela forma de falar, } \\
\text { pela opção sexual etc. }\end{array}$ \\
\hline
\end{tabular}

Além disso, cada forma de intolerância não está necessariamente isolada. Há muitos casos - e talvez seja o mais comum - em que mais de uma 
forma de intolerância existe em determinado regime de sentido intolerante. Tomemos o caso mais conhecido: o Holocausto. Considerado como um processo, é possível observar que o Holocausto tem uma sintaxe da intolerância muito bem definida: começando pela segregação de judeus, homossexuais e ciganos, limitando-os a guetos; em seguida, há a exclusão desses grupos do convívio com a sociedade alemã, quando eles são levados aos campos de concentração; por fim, a solução final do regime nazista, com a linha de produção de assassinato em massa para eliminar essas presenças.

Em relação à tolerância, podemos recorrer às definições, principalmente, de Walzer e de Aurélio para compreendermos como ela se organiza. Dessa forma, podemos pensar em uma tolerância átona, cuja principal característica é a de conhecer a alteridade e, por consequência, aceitar a diferença constitutiva do outro. Já uma tolerância tônica vai apresentar uma compreensão da alteridade, ou seja, um entendimento completo do outro e de suas razões. Por fim, uma tolerância mais forte é aquela do reconhecimento do outro, do seu estatuto e de suas características, chegando a uma postura solidária com a alteridade, em uma interação completa. Dessa forma, podemos apresentar o lugar ocupado por essas três formas no esquema tensivo:

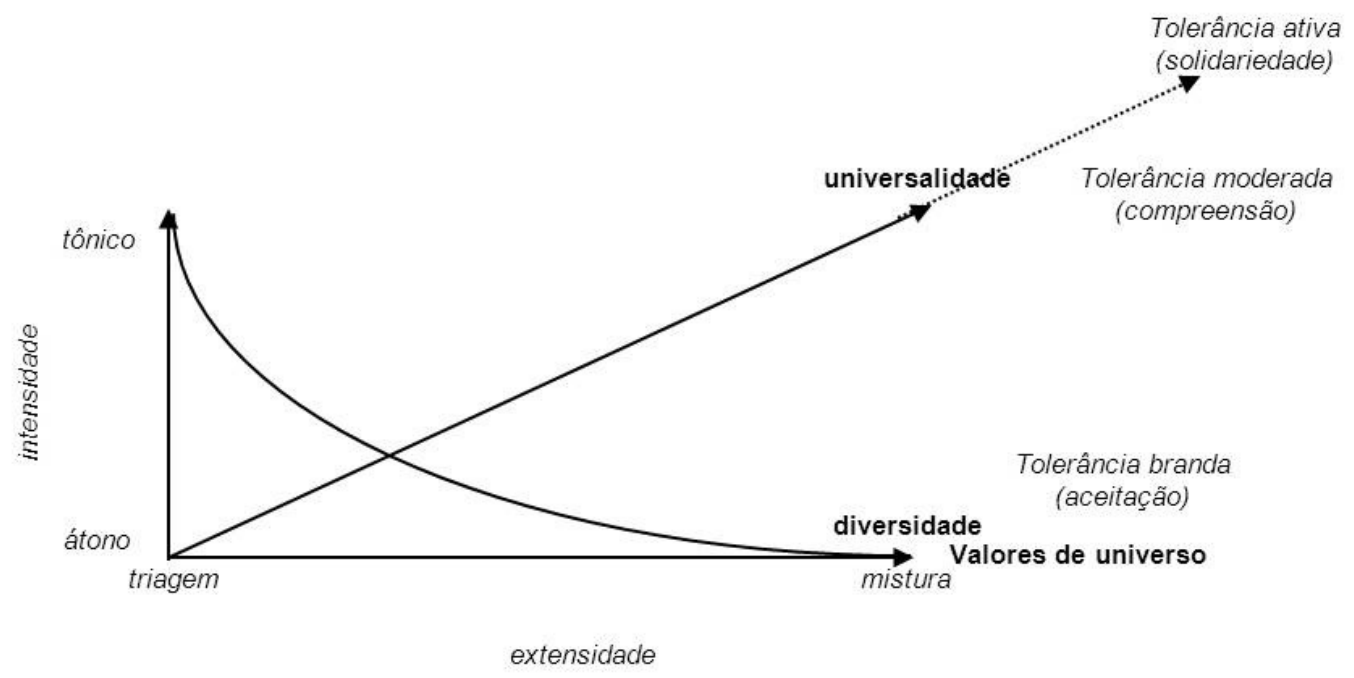

Do lado da tolerância no esquema tensivo, podemos entender o valor de diversidade como base do pluralismo e do relativismo cultural. Nesse caso, a identidade e a alteridade podem conviver, cada uma conhecendo e respeitando as especificidades de cada uma, mas sem muitas interações. Os valores de diversidade são, então, uma resposta apropriada para se evitar o surgimento 
da intolerância, porque é possível defender-se das tentativas de homogeneização decorrentes da triagem. O pluralismo de ideias ou relativismo cultural, de opiniões e de valores, por estar no eixo da mistura átona (nos valores da diversidade), deve ser um espaço aberto no qual serão acolhidas todas as formas de alteridade de forma indiscriminada (em uma concepção próxima à de tolerância negativa proposta por Bobbio).

A mistura pode também ser tônica e, nesse caso, ela vai levar a uma maior compreensão da alteridade por se acreditar que essa instância pode também contribuir para a formação dos valores universais (não cabendo apenas à identidade a premissa da formação desses valores). Nesse caso, a interação entre identidade e alteridade é maior com uma compreensão das características de cada uma das instâncias em relação (nem sempre iguais).

Por fim, ultrapassando a universalidade, pode-se pensar em uma atitude mais ativa de conhecimento da alteridade, tal como vislumbrada por Rouanet: a interpenetração e a solidariedade são, então, uma interação que envolve tanto o inteligível como o sensível, no qual ambos, identidade e alteridade, estão em igualdade de condições para, cada uma a sua maneira, influir e transformar a outra em benefício de ambas.

Da mesma forma que fizemos com a intolerância, pensamos em um quadro da tolerância que resuma a relação entre valores, interações e temas:

\begin{tabular}{|c|c|c|c|}
\hline $\begin{array}{l}\text { Formas de } \\
\text { intolerância } \\
\text { (valores) }\end{array}$ & $\begin{array}{c}\text { Tolerância ativa } \\
\text { (conjunção dos } \\
\text { valores de absoluto } \\
\text { e de universo) }\end{array}$ & $\begin{array}{c}\text { Tolerância } \\
\text { moderada } \\
\text { (mistura tônica) } \\
\text { (universalidade) }\end{array}$ & $\begin{array}{l}\text { Tolerância branda } \\
\text { (mistura átona) } \\
\text { (diversidade) }\end{array}$ \\
\hline Operação & União com o outro & $\begin{array}{c}\text { Assimilação do } \\
\text { outro }\end{array}$ & Admissão do outro \\
\hline Temas & $\begin{array}{c}\text { Reconhecer o } \\
\text { outro como um } \\
\text { igual; } \\
\text { solidariedade; } \\
\text { fraternidade }\end{array}$ & $\begin{array}{c}\text { Vontade de } \\
\text { compreender o } \\
\text { outro; } \\
\text { consideração }\end{array}$ & $\begin{array}{c}\text { Aceitação das } \\
\text { diferenças do outro; } \\
\text { respeito }\end{array}$ \\
\hline
\end{tabular}


Podemos, então, observar que a tolerância branda é uma aceitação da diferença existente no outro. Por isso, esse outro é admitido pelo sujeito tolerante, mas sem a realização efetiva de uma interação com a alteridade. Já a tolerância moderada apresenta um /querer-saber/, representada pela vontade de conhecer o outro (sua história, valores, hábitos, comportamentos etc.) e a interação é maior (em relação à forma anterior de tolerância), porque há uma consideração da identidade em relação à alteridade. Por fim, a tolerância ativa é uma forma de solidariedade ou mesmo de interpenetração (conforme propõe Rouanet) como forma de interação entre identidade e alteridade. Nessa interação, por ser mais intensa, podemos dizer, hipoteticamente, que as categorias de identidade e de alteridade se desfazem nessa forma de interação.

Por fim, podemos apresentar o esquema tensivo completo com todos os valores representados:

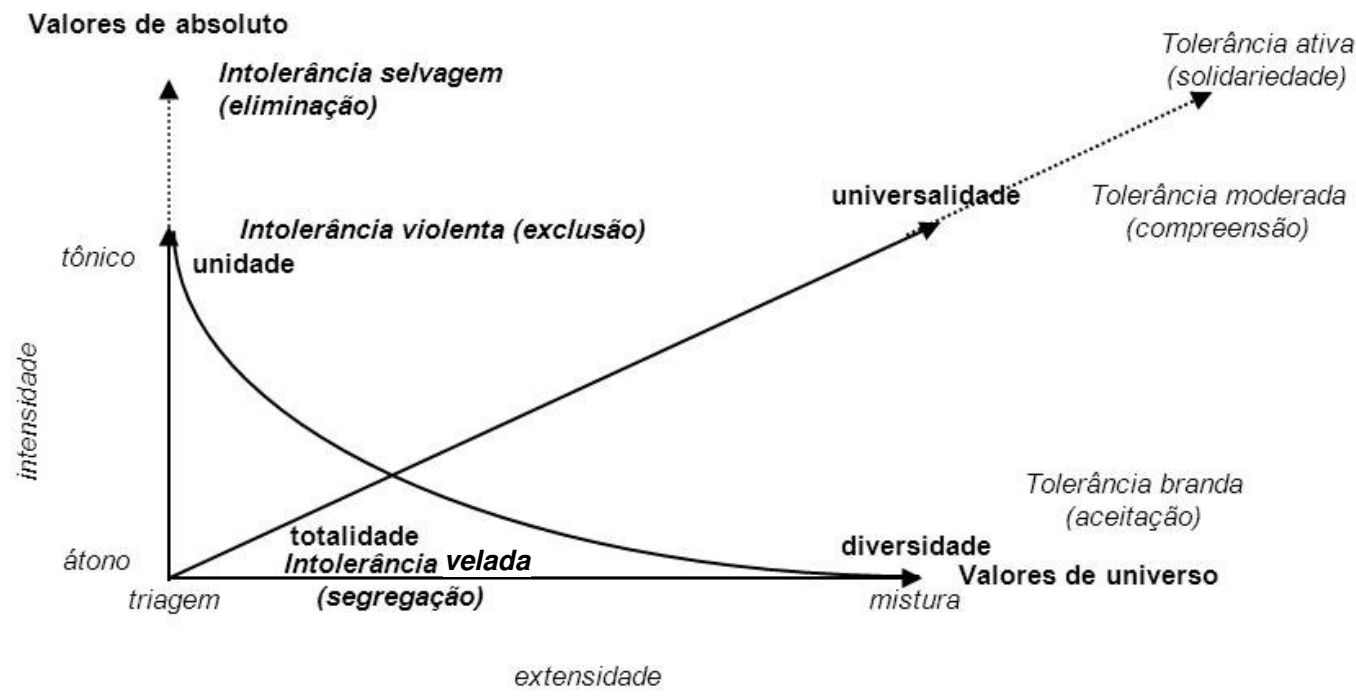

Quando o valor, no nível profundo, converte-se em objeto-valor do nível narrativo, a questão da interação começa a tomar contornos mais definidos, porque ele passa a circular entre os sujeitos. Por isso, apresentaremos em uma nova seção o conceito de interação desenvolvido por Landowski em seus trabalhos mais recentes $(2004,2006)$. Dessa forma, poderemos compreender como a intolerância e a tolerância organizam-se nos substratos mais complexos do percurso gerativo do sentido. 


\subsection{A sintaxe do discurso intolerante: a interação sensível e passional, do nível narrativo às instâncias enunciativas}

Desde os anos iniciais de seu desenvolvimento teórico, a interação esteve presente no quadro teórico da semiótica greimasiana, mas não com essa denominação ${ }^{64}$. A interação, no entanto, pode ser observada no nível narrativo, na relação entre destinador e destinatário. Também podemos observar a interação na relação mediada pelo objeto que é disputado pelo sujeito e pelo antissujeito. De certo modo, essas interações estão mais próximas de uma racionalidade que exclui a questão passional com a qual a semiótica vem trabalhando desde a década de 1990.

Parece-nos que Eric Landowski foi o responsável por colocar a interaçã ${ }^{65}$ como um dos pontos centrais das reflexões semióticas, a partir de um texto intitulado "Algumas condições semióticas da interação", publicado em A sociedade refletida (1992). Nesse texto, para contrapor a noção de interação da semiótica com outras teorias, como a pragmática, o autor recorre ao conceito de imanência, tão cara à semiótica greimasiana. Assim, para a semiótica, o contexto (no qual ocorre a interação propriamente dita) não está aquém ou além da linguagem, mas está no cerne da própria. Em outras palavras, o autor (1992: 146-149) defende que o contexto é construído pela linguagem, ao contrário de outras teorias que defendem a existência de um contexto e de uma realidade previamente existentes.

Landowski propõe novos desenvolvimentos a respeito da interação em outro trabalho: Presenças do Outro (1997). Nesse livro, o autor (1997: 5 et seqs) elabora novas noções de interação a partir do conhecido conceito de junção ${ }^{66}$. Há, assim, quatro possibilidades de interação inicialmente contempladas: assimilação (conjunção), exclusão (disjunção), admissão (não disjunção) e segregação (não conjunção). Esses quatro conceitos, segundo o

\footnotetext{
${ }^{64}$ Não há nenhum verbete referente a essa noção no primeiro Dicionário de Semiótica (2008). No segundo Dicionário de Semiótica (sem tradução para o português) (1986), há duas definições de interação escritas por Gracia Latella e por Peter Stockinger.

${ }^{65}$ Essa interação, em um primeiro momento, será analisada entre os actantes, mas posteriormente tentaremos também verificar a interação entre o enunciador e o enunciatário.

${ }^{66}$ A junção é a relação lógico-narrativa que determina o modo de relacionamento de um sujeito com seu objeto (conjunção/disjunção) (Barros, 1988: 30). No trabalho de Landowski, a relação não se faz, no entanto, entre um sujeito e um objeto, mas entre sujeitos em interação.
} 
autor (1997: 37 et seqs), referem-se às possibilidades de interação de uma identidade em relação a uma alteridade. Mas a alteridade também possui, nesse modelo, suas estratégias de interação com a identidade, que estão igualmente baseadas na noção de junção ${ }^{67}$ : a alteridade que deseja ser assimilada (conjunção), a que deseja ser excluída (disjunção), que quer ser admitida (não disjunção) e a que quer manter-se segregada (não conjunção). Um aspecto interessante desse modelo de interação está na possibilidade de combinação entre os modos de interação da identidade e as estratégias da alteridade. Com isso, abre-se uma gama relativamente ampla de combinações que podem estar em conformidade ou em confronto, como, por exemplo, uma identidade assimiladora (conjunção) que se confronta com uma alteridade que deseja manter-se segregada (não conjunção) ou uma identidade exclusivista que encara uma alteridade que deseja a assimilação, entre outras possibilidades. Essas combinações resultam em um total de 16 conformações ou confrontações possíveis de diferentes tipos de interação e, consequentemente, de surgimento de distintas significações (1997: 50-52) ${ }^{68}$.

Em outro livro, Passions sans nom (2004) ${ }^{69}$, Landowski propõe o conceito de união para abordar novas formas de interação que englobam a dimensão sensível da interação. É por meio da noção de união que o mesmo autor, em seu último trabalho, Les interactions risquées ${ }^{70}$ (Landowski, 2006), apresenta uma nova tipologia das interações baseada na união e na junção: ajustamento, acidente, programação e manipulação. Em Les interactions risquées (2006), Landowski investiga a noção de risco (entendida pelo autor como uma multiplicidade de pequenas incertezas) em cada um dos quatro novos regimes de interação que ele propõe. O autor postula uma espécie de gradação do risco, uma vez que ele estaria sempre presente nos regimes de interação de qualquer tipo.

\footnotetext{
${ }^{67}$ Landowski utiliza os seguintes nomes para definir essas estratégias da alteridade: esnobe (conjunção), dândi (disjunção), camaleão (não disjunção) e urso (não conjunção). Contudo, não os utilizamos como conceitos por causa da ambivalência ou motivação semântica gerada por esses nomes.

${ }^{68}$ Em nossa dissertação de mestrado, examinamos a intolerância no modelo de interação proposto por Landowski em Presenças do Outro (1997). Não descartamos o uso desse modelo em nossas análises, mas não o descrevemos neste capítulo para não nos repetirmos.

${ }^{69}$ Parte do desenvolvimento dessa seção foi publicada na revista Estudos Semióticos (Bueno et al., 2010).

${ }^{70} \mathrm{O}$ livro Les interactions risquées (2006) pode ser entendido como um prolongamento e um refinamento de algumas ideias já apresentadas pelo autor em Passions sans nom (2004).
} 
O ajustamento é definido pelo autor como uma construção recíproca entre sujeitos ou entre sujeitos e objetos, ou seja, como parceiros na interação, na qual as potencialidades da alteridade poderiam ser atualizadas por meio desse ajustamento (Landowski, 2004: 29). Nesse regime, seria possível postular certa autonomia dos actantes (um sujeito ou um objeto) em relação ao actante-principal, fonte de referência de um determinado programa narrativo. Dessa forma, os actantes se ajustariam entre si e desse ajustamento surgiriam novos sentidos, sentidos não esperados, mas fruídos por ambos os actantes em interação por meio da união.

Para Landowski (2004: 62), o conceito de união serviria, assim, para explicar os estados de alma e os estados somáticos dos sujeitos em interação, que não é mais respaldada por uma lógica juntiva, mediada por objetos, mas por uma interação face-a-face, corpo-a-corpo, ou seja, uma copresença mútua. Essa copresença, entre sujeitos ou entre sujeito e objeto, envolveria, então, não mais um conhecer, um julgar, um decidir ou um avaliar a distância, mas uma relação da ordem do sensível, ou seja, mais receptiva às qualidades sensíveis do objeto e dos sujeitos em interação.

O ajustamento pode ser entendido como a interação atravessada pelo sensível e pela estesia, independente do estado juntivo. Ao ajustar-se um ao outro, condição necessária para a construção de outro sentido, ambos constituiriam, por algum tempo, um objeto complexo novo, uma totalidade inédita. Resumindo, o ajustamento é um modo de interação e de construção do sentido condicionado pela copresença de actantes e pela possibilidade de relação sensível entre eles (Landowski, 2004: 63).

A alteridade pode ser entendida da seguinte forma no regime de ajustamento: apesar desse outro (sujeito ou objeto) não possuir o mesmo estatuto da identidade, ele não é também uma pura passividade, pois ele possui certa autonomia. Mas essa autonomia só adquire determinado valor por meio de um fazer em ato da identidade. O exemplo apresentado por Landowski para o regime de ajustamento é a dança. $\mathrm{Na}$ dança, ambos os actantes constroem um discurso único no momento em que o parceiro vai se ajustando ao movimento do outro, conforme ela evolui.

Em relação ao acidente, Landowski (2006: 62) o define como uma interação na qual se embaralham todos os valores do sujeito em interação. $A$ 
primeira definição de acidente está relacionada a um acontecimento extraordinário ou inesperado. Esse tipo de definição está próximo dos acidentes naturais, como enchentes, tornados, terremotos etc. Mas há uma segunda acepção de acidente, em que o embaralhamento modal é produzido pela figura de um destinador, que não propõe mais um contrato, nem exige nada em troca. Esse destinador estaria mais próximo do destinador-julgador, mas sem se comunicar com os sujeitos e restringindo-se a julgá-los de modo positivo ou negativo sem justificar suas decisões (Landowski, 2006: 69). O acidente ocorre, então, quando surge uma decisão não prevista que influencia o programa narrativo de certos sujeitos. Esse é o caso, por exemplo, de uma ditadura que elimina todas as liberdades civis e políticas da sociedade que "governa". A organização modal desse sujeito-sociedade é abalada por essa decisão, e o sujeito perde a sua direcionalidade no programa narrativo em que estava localizado. Dessa forma, o acidente rompe com a continuidade para instaurar outra possibilidade de sentidos para esses sujeitos, que nada podem fazer.

Podemos compreender o regime de programação como uma operação regida pela regularidade. Essa regularidade, por conseguinte, pode ser entendida de duas maneiras: a primeira é a programação definida tradicionalmente pela semiótica. Essa é a programação do sujeito em sua relação com o objeto, tal como é visto nos "contos populares": se uma personagem é um pescador, ela apenas pescará e nada mais; da mesma forma, se a personagem é um rei, ela irá apenas governar seu reino e assim por diante (Landowski, 2006: 17). A segunda forma de se entender a regularidade da programação está no sujeito em interação social. O sujeito, para Landowski, pode ser programado a partir do que ele chama de "constrangimento social". Haveria, assim, a partir de normas sociais instituídas, toda uma programação quase tão rígida quanto à primeira. Essa rigidez produzida pelo constrangimento social pode ser, então, entendida como um /fazer-ser/ restrito que levaria o sujeito a um comportamento social padronizado (Landowski, 2006: 19). O exemplo dado por Landowski é o de uma festa de gala: o sujeito não poderia se vestir de outra maneira que não fosse com um smoking, a não ser que desejasse passar vergonha. Esse mesmo sujeito também não poderia se comportar da maneira que lhe aprouvesse, a não ser 
que quisesse se destacar e chamar a atenção dos demais participantes da festa. O que há em comum nas duas formas de programação propostas é a noção de papel temático, ou seja, a presença de um único traço semântico que define e restringe o /fazer/ de um determinado actante.

Para definir o regime de manipulação, Landowski retoma o princípio de intencionalidade. De um lado, há as estratégias de tentação e de intimidação que tiram sua eficácia manipulatória do valor positivo ou negativo do objeto e, no limite, pode ser considerado como um acordo entre destinador e destinatário por meio do contrato (em que se prevê o prêmio ou a punição). Nessas duas estratégias de manipulação, a intencionalidade é de ordem objetiva. De outro lado, as estratégias da sedução e da provocação envolvem a valorização ou a desvalorização da imagem do destinatário. Nesse caso, a intencionalidade é subjetiva (Landowski, 2006: 20-23).

A manipulação envolve, ainda, a competência modal do sujeito do fazer, o que não é garantia de qualquer tipo de sucesso na interação entre actantes (até porque o destinatário pode recusar a manipulação). Há, então, certa imprevisibilidade na manipulação, porque ela envolve sistemas de valores, interpretação, preferências e gostos distintos entre o destinador e o destinatário (Landowski, 2006: 24).

Segundo o autor, há duas possibilidades de resolução dessa incerteza na manipulação: a primeira, a de transformar o destinatário em um não sujeito (o caso da tentação e da intimidação) que o conduziria a certa programação de seu fazer, despertando nesse destinatário um /querer-fazer/ para ser recompensado ou um /dever-fazer/ por medo. A outra solução é o de tentar entrar na "consciência" do destinatário. Nesse momento, o destinador começaria a se colocar no lugar do outro. Para tentar se colocar no lugar do outro (do destinatário), no regime de manipulação, o destinador precisa também localizar os "pontos sensíveis" do destinatário para poder de fato manipulá-lo, tanto por provocação quanto por sedução. Há, assim, também a necessidade de uma interpretação ${ }^{71}$ do destinador nesse processo de manipulação (Landowski, 2006: 26-28).

\footnotetext{
71 Entendemos que o deslocamento da interpretação, do destinador julgador para o destinador manipulador, é fundamental para se compreender o discurso intolerante, como veremos adiante.
} 
Após essa rápida apresentação da proposta de Landowski, podemos nos debruçar mais detidamente na configuração da interação no discurso intolerante e tolerante. Entendemos que, tal como definida, é pouco provável que haja alguma intolerância no regime de ajustamento. No entanto, podemos pensar nas consequências desse regime de interação para, principalmente, a alteridade. Uma interação no regime do ajustamento implica uma troca igualitária de sentidos e de sensações. O problema pode existir depois dessa interação: uma das partes, no caso a alteridade, pode sentir-se prejudicada após essa interação se a relação igualitária não se mantiver depois. Se, por exemplo, houver um retorno para o regime de manipulação ou para o regime da programação, a relação entre identidade e alteridade pode voltar a ser hierarquizada e desigual.

Podemos associar a programação ao conceito de estereótipo, entendido como uma restrição da imagem de um determinado ator do discurso. A estereotipia pode ser entendida como um fazer negativo quando aplicado na construção da imagem de um determinado grupo social, principalmente quando essa imagem é contrária aos valores considerados positivos pela sociedade.

Em relação ao regime do acidente, ele ocorreria quando uma decisão é tomada por uma instância superior (no caso, o destinador) sem que se considere o percurso do sujeito em um determinado programa narrativo, fazendo-o sair desse programa por causa do embaralhamento de seus valores e de sua organização modal. Outra possibilidade do regime do acidente ocorre quando dois programas narrativos se "chocam" e o sujeito mais fraco vê também suas modalidades serem embaralhadas.

No caso da manipulação, não há necessidade de estabelecermos hipóteses, uma vez que Barros (2007a; 2008) apresenta não apenas o papel da manipulação no discurso intolerante, mas todo o percurso narrativo, com repercussões também na dimensão passional. No nível narrativo, o exame do discurso intolerante recai em duas etapas: a primeira, na sanção aplicada pelo destinador-julgador $^{72}$ a um sujeito que não cumpriu de modo satisfatório

\footnotetext{
72 Baseados na definição de Paul Ricoeur, podemos dizer que a intolerância é uma dupla sanção: cognitiva e pragmática. Cognitiva porque não se reconhece o outro como capaz de um determinado fazer, ser ou crer. Pragmática porque o destinador-julgador é dotado de um poder forte o suficiente para excluir, segregar ou ainda tentar assimilar o outro, mas sempre tendo em mente que o outro não cumpriu seu contrato e, por isso, não tem condições de se manter dentro do contrato fiduciário. Como ele não é
} 
determinado contrato social estipulado anteriormente (como o de falar bem, o de se comportar de maneira apropriada, o de relegar seus valores de origem para ser integrado à sociedade). Em termos de narratividade, esses sujeitos não entram em conjunção com o objeto de valor proposto pelo contrato, porque eles não querem, ou não podem, ou não sabem como entrar em conjunção. Consequentemente, por se manterem em disjunção com o objeto de valor, esses sujeitos são reconhecidos como não cumpridores do contrato e, por isso, devem ser punidos. $O$ outro momento está relacionado a essa punição: o discurso intolerante envolve paixões malevolentes (como o ódio, a raiva, o rancor, a inveja) o que leva a um querer fazer mal a outro sujeito por ele não querer, não poder ou não saber cumprir o contrato proposto. Esse fazer mal ao outro é a própria intolerância, enquanto a etapa em que surgem as paixões malevolentes é considerada como o preconceito. Além disso, o discurso intolerante pode apresentar paixões benevolentes que envolvem temas como 0 amor à pátria (nacionalismo) ou a solidariedade ao grupo social do sujeito intolerante. Como diz Barros, "é esse jogo entre o querer fazer mal aos diferentes e o querer fazer bem a seus iguais que caracteriza o sujeito apaixonado intolerante" (2008: 343-344).

Como já apontado por Barros, o discurso intolerante envolve a dimensão passional do discurso. Passaremos, então, a algumas considerações a respeito das paixões no discurso intolerante.

\subsection{Etapas do discurso intolerante: percursos entre a razão e a paixão malevolente}

Em seu estudo sobre a paixão da cólera, Greimas desenvolve magistralmente os percursos de reparação da falta por um sujeito em estado de carência. Esse estado pode ser gerado, por um lado, pelo destinadorjulgador que não cumpre sua parte do contrato fiduciário inicialmente estatuído pelo destinador-manipulador e, por outro lado, pode ser o efeito de um antissujeito que toma o objeto-valor de um sujeito do fazer (aquele que foi manipulado e aceitou os termos e valores do contrato fiduciário). Em outras

identificado como fazendo parte do conjunto de valores do destinador, ele poderá ser eliminado, excluído ou segregado do percurso narrativo, a depender do modo como o destinador se relaciona com seus próprios valores. 
palavras, o sujeito em estado de carência é levado a essa situação por um descumprimento do contrato por parte do destinador ou pelo fazer de um antissujeito e para eliminar a falta produzida por esses dois actantes, o sujeito pode iniciar um percurso de reparação contra o destinador, o que produziria 0 percurso da revolta, ou contra o antissujeito, produzindo o percurso da vingança. No entanto, como não foi seu objetivo, Greimas não desenvolveu os elementos que permitiriam compreender a produção do efeito de carência no sujeito passional. Dessa forma, veremos como a organização da intolerância pode estar relacionada com o descumprimento do contrato pelo destinadorjulgador ou pela ação do antissujeito.

Tomamos emprestado o esquema passional elaborado por Bertrand (2003), feito a partir das propostas de Greimas e Fontanille em Semiótica das Paixões (1993): disposição, sensibilização, emoção e moralização. Ao mesmo tempo, correlacionaremos o percurso passional ao percurso narrativo clássico, uma vez que compreendemos a intolerância como um fenômeno que engloba tanto a dimensão passional como a cognitiva e a pragmática ${ }^{73}$. O papel das paixões no discurso intolerante está relacionado com o esquema narrativo canônico: a manipulação, por exemplo, pode estar ligada à organização da disposição passional do sujeito intolerante. E assim com a aquisição ou a atribuição das competências (sensibilização), na execução da ação (emoção) e, por fim, na sanção (moralização). De certa forma, essa opção explicaria como atos intolerantes impensados buscam uma justificativa racional para sua ação devastadora.

Começando pela disposição, pensamos que o sujeito intolerante é definido por diferentes gradações do /crer-ser/ que vão modular sua relação com os valores. À medida que esse /crer/ se torna mais intenso, maior será o fechamento do sujeito intolerante diante da alteridade. Em um momento anterior à disposição, o sujeito intolerante é um sujeito relaxado por estar em relação apenas com os seus valores. Ao surgir a alteridade em seu horizonte, o sujeito intolerante passa imediatamente a um estado de tensão.

\footnotetext{
${ }^{73}$ Segundo Greimas e Fontanille: "Desse ponto de vista [o de encadeamento de fazeres] e nesse nível de análise, a sintaxe passional não se comporta diferentemente da sintaxe pragmática ou cognitiva; ela assume a forma de programas narrativos, em que um operador patêmico transforma estados patêmicos; as dificuldades começam quando se examinam as interferências entre as diferentes dimensões" (1993: 5051).
} 
Em relação à sensibilização, podemos imaginar o seguinte: para uma identidade qualquer, surge uma alteridade. Diante dessa alteridade, a identidade vai passar a tecer certas considerações a partir de um primeiro /fazer-interpretativo/. No /fazer-interpretativo/, já estão envolvidos os valores da identidade, que acabam se confrontando com os valores da alteridade. Dentre as diferentes possibilidades, uma é a de considerar a presença da alteridade como uma presença insuportável, porque se diferencia (em demasia ou não) da identidade. Nesse momento, o sujeito intolerante pode sentir que a alteridade é uma ameaça à sua organização modal de sujeito competente e à sua segurança para a continuidade de sua existência. A sensação de ameaça já se constrói nessa etapa como um simulacro, ou seja, como uma imagem fixada construída pelo próprio sujeito intolerante em sua interpretação da alteridade. A presença da alteridade faz, então, com que o sujeito intolerante se sinta ameaçado, como já dissemos, porque sua organização modal (tanto a do /fazer/ como, principalmente, a do /ser/) é colocada à prova, assim como suas certezas e seu apego aos valores. Consequentemente, a identidade passará a um determinado /fazer/ para que essa presença deixe de existir, ao menos de forma imediata para a identidade.

Assim, o sujeito intolerante passa a etapa da emoção. Como tudo o que for estranho ao sujeito intolerante passa a ser visto como uma ameaça à sua própria integridade, ele vai realizar um /fazer-malevolente/ que vise à eliminação dessa presença estranha (da alteridade). A partir daí, ele pode desencadear diferentes percursos da intolerância. $\mathrm{Na}$ intolerância selvagem, ele vai procurar eliminar completamente a existência da alteridade, o mais rápido possível. $\mathrm{Na}$ intolerância violenta, esse sujeito intolerante vai realizar a exclusão, mesmo porque esse sujeito possui uma relação menos intensa com os valores nos quais acredita, mas ainda assim uma relação forte/tônica. E a intolerância átona é, por fim, uma segregação, na medida em que o sujeito intolerante apenas rejeita algumas presenças da alteridade e, por isso, as manteria a distância.

É ainda na etapa da emoção que o sujeito intolerante desenvolve o sentimento de ódio pela alteridade, sobretudo pela forma da intolerância selvagem. Na intolerância violenta, a emoção predominante é a da raiva, enquanto na intolerância átona predomina o sentimento de repulsa à 
alteridade. Dessa forma, o sujeito intolerante passa a se sentir um sujeito ameaçado e passa a visar uma maneira de eliminar essa ameaça.

Por fim, a moralização apresenta duas possibilidades: a primeira, quando o actante coletivo (sociedade) aprova tal atitude intolerante e, assim, o próprio sujeito intolerante passa a considerar tal supressão da alteridade como algo normal e, por vezes, banal. A segunda possibilidade decorre da desavença entre o que é socialmente aceito e a atitude do sujeito intolerante. Mesmo assim, o sujeito intolerante pode acreditar que seu ato é uma forma de reparação ou de proteção à dimensão social, mesmo quando essa própria dimensão se coloca contrária a ele.

\begin{tabular}{|c|c|c|c|c|}
\hline & Disposição & Sensibilização & Emoção & Moralização \\
\hline $\begin{array}{l}\text { Intolerância } \\
\text { selvagem }\end{array}$ & $\begin{array}{c}\text { Aversão total } \\
\text { à diferença e } \\
\text { extremo } \\
\text { apego aos } \\
\text { seus valores }\end{array}$ & $\begin{array}{l}\text { Sentir-se } \\
\text { ameaçado } \\
\text { (medo) }\end{array}$ & $\begin{array}{l}\text { Eliminação do } \\
\text { outro } \\
\text { (ódio) }\end{array}$ & $\begin{array}{l}\text { Aprovação ou } \\
\text { reprovação do /fazer- } \\
\text { malevolente/ do sujeito } \\
\text { intolerante }\end{array}$ \\
\hline $\begin{array}{l}\text { Intolerância } \\
\text { violenta }\end{array}$ & $\begin{array}{c}\text { Desprezo pela } \\
\text { diferença e } \\
\text { forte apego } \\
\text { aos seus } \\
\text { valores }\end{array}$ & $\begin{array}{l}\text { Sentir-se } \\
\text { ameaçado } \\
\text { (medo) }\end{array}$ & $\begin{array}{c}\text { Exclusão do } \\
\text { outro } \\
\text { (raiva) }\end{array}$ & $\begin{array}{l}\text { Aprovação ou } \\
\text { reprovação do /fazer- } \\
\text { malevolente/ do sujeito } \\
\text { intolerante }\end{array}$ \\
\hline $\begin{array}{l}\text { Intolerância } \\
\text { velada }\end{array}$ & $\begin{array}{c}\text { Rejeição à } \\
\text { diferença e } \\
\text { apego aos } \\
\text { seus valores }\end{array}$ & $\begin{array}{l}\text { Sentir-se } \\
\text { ameaçado } \\
\text { (medo) }\end{array}$ & $\begin{array}{c}\text { Segregação do } \\
\text { outro } \\
\text { (repulsa) }\end{array}$ & $\begin{array}{l}\text { Aprovação ou } \\
\text { reprovação do /fazer- } \\
\text { malevolente/ do sujeito } \\
\text { intolerante }\end{array}$ \\
\hline
\end{tabular}

O quadro acima pode ser lido, no percurso, de forma transversal. É por isso que mesmo em um regime baseado na intolerância selvagem, pode haver uma justificativa por meio do medo ou da defesa dos valores caracterizadores da identidade. Da mesma forma, diferentes intolerâncias podem ser camufladas por meio de uma intolerância átona ou mesmo por um discurso tolerante.

Após a apresentação dos elementos que constituem 0 discurso intolerante, passaremos a aplicação desses conceitos e configurações semióticas nos textos que tratam da imigração no Brasil. 


\section{O discurso jurídico sobre o estrangeiro no Brasil}

\subsection{Preliminares}

O Direito pode ser entendido como um conjunto de normas imposto pelo Estado. Essas normas impõem limites à liberdade humana e punições para quem os ultrapassa (Fiuza, 2008: 2-5). Assim, o Direito é uma das formas de se regular as relações em uma sociedade. Para ter essa capacidade de regulação da sociedade, o Direito necessita materializar essas características em forma de texto.

Para este capítulo, retomamos os estudos semióticos do discurso jurídico. A nossa base será a clássica análise da lei de sociedades comerciais, realizada por Greimas e Landowski (apud Greimas, 1981). Como apontam os semioticistas, o discurso jurídico tem por característica apreender elementos da "realidade" (social ou não) para transferi-los ao universo jurídico. O discurso jurídico legisla não apenas sobre as ações dos sujeitos, mas também sobre o ser dos sujeitos. Veremos, assim, como o universo jurídico organiza o ser de sujeitos no espaço social ao tratar da questão da nacionalidade.

O discurso jurídico apresenta ainda dois tipos de enunciado: o enunciado qualificativo, responsável por atribuir determinadas qualidades ao objeto, e o enunciado funcional, que trata de regulamentar o fazer dos sujeitos (Greimas e Landowski, 1981: 77-78).

Em relação ao enunciado qualificativo, o discurso jurídico mostra que um determinado objeto só pode ter existência jurídica a partir do momento que é instaurado pelo enunciador. Como afirmam Greimas e Landowski: "só o que é explicitamente dito possui o estatuto de existente" (1981: 78). Por isso, nomear e definir são duas características primordiais do discurso jurídico. $O$ enunciado funcional vai, por sua vez, regulamentar o /fazer/ relativo ao discurso referencial. Assim, segundo os autores, o enunciado funcional prescreve ou proíbe comportamentos de um dado discurso referencial. É nesse ponto que os dois tipos de discurso, legislativo e referencial, se encontram no discurso jurídico (Greimas e Landowski, 1981: 78-79).

Pelo que foi exposto acima, para legislar sobre determinado assunto, o discurso jurídico precisa apresentar uma definição clara do tema tratado. Nesse 
ato de definição, é possível, assim, pensar em como um tema é discursivamente construído por uma lei. Há também outros meios de se enriquecer a definição apresentada pelo discurso jurídico por meio da depreensão de diferentes percursos narrativos e organizações modais associados ao tema da lei que não estão necessariamente presentes na parte reservada à definição. São esses dois lados da lei que abordaremos para examinar a representação discursiva do estrangeiro no Brasil. Assim, observaremos como as leis organizam seus valores e os projetam em diferentes formas de alteridade, construindo uma imagem positiva ou negativa dos estrangeiros em geral, dos imigrantes e do refugiado. Examinaremos também como as leis sobre o estrangeiro constroem a representação do que é ser brasileiro.

Trataremos inicialmente da Lei no 818, de 18 de setembro de 1949, que apresenta definições da nacionalidade brasileira e dos processos necessários para o pedido de naturalização em um momento próximo ao final da Segunda Guerra Mundial. Em seguida, analisaremos a Lei no 6.815, de 19 de agosto de 1980, que regulamenta a situação e o estatuto jurídicos do estrangeiro no Brasil já no final do governo militar brasileiro. Por fim, examinaremos a Lei $\mathrm{n}^{0}$ 9.474, de 22 de julho de 1997, que legista sobre o estatuto do refugiado no Brasil, outra forma de alteridade que mereceu uma lei específica para regularizar sua presença no país.

\subsection{Sobre a nacionalidade brasileira e sua aquisição}

\section{Introdução}

Segundo Mello, a nacionalidade possui duas definições em campos distintos do saber: a sociológica e a jurídica. A nacionalidade, em sua definição sociológica, é um agrupamento de pessoas com uma mesma língua, raça, religião e um desejo de viver junto ${ }^{74}$. Já a definição jurídica de nacionalidade

\footnotetext{
${ }^{74}$ Segundo o mesmo autor, essa definição de nacionalidade está por trás da fundação de algumas nações, como a alemã, a italiana e a francesa. A abordagem histórica e sociológica do conceito de nação é muito longa e complexa para discutirmos em poucas linhas deste trabalho. Para uma noção mais aprofundada das diferentes formas de se definir a nacionalidade e a nação, remetemos ao trabalho de Thiesse (2001).
} 
reforça a ligação do indivíduo a um Estado (e não à nação). Por isso, o indivíduo é considerado, no campo jurídico, como um membro do Estado por manter um vínculo jurídico-político com ele (2002: 953-954).

A importância da nacionalidade, para o campo jurídico e o sociológico, pode ser observada pelo fato de estar na Declaração Universal dos Direitos do Homem:

1. Todo homem tem direito a uma nacionalidade. 2 Ninguém será arbitrariamente privado de sua nacionalidade, nem do direito de mudar de nacionalidade (apud Mello, 2002: 955)

Nesta seção, analisaremos a lei $n ² 18$ (de 1949), que regularizou a aquisição, a perda e a reaquisição da nacionalidade. Inicialmente, a lei apresenta suas definições do que é ser brasileiro. Segundo nossa proposta, a definição de nacionalidade tem como um de seus pilares a noção de contrato ${ }^{75}$. Por essa razão, a lei estabelece diferentes percursos para se chegar a uma conjunção com a nacionalidade brasileira (ou seja, para se conquistar o elo do indivíduo com o Estado brasileiro, como mencionamos acima).

Um desses percursos merecerá uma análise mais detida. Trata-se do percurso que um estrangeiro deve percorrer para se tornar brasileiro (o processo de naturalização). Examinaremos também as demais formas de se ter ou adquirir a nacionalidade brasileira, assim como as formas de se perdê-la. No caso da perda, a lei não engloba apenas os imigrantes, mas também brasileiros natos que podem, assim, perder a sua nacionalidade por motivos previstos pela lei.

Apresentaremos resumidamente as principais características da presente lei com o intuito de facilitar a análise que será realizada.

\footnotetext{
Nesse trabalho, Thiesse mostra como a língua, a cultura e a história foram utilizadas para a fundação das nações modernas, tendo como base a noção de unidade nacional.

75 No Direito, há duas correntes de pensamento sobre a nacionalidade. De um lado, a que enfatiza o vínculo político e jurídico entre indivíduo e Estado; de outro, a corrente que afirma a noção de contrato entre indivíduo e Estado. Mello critica a corrente contratualista porque ela não explicaria como um recém-nascido contrai um contrato com o Estado em que nasce. De nossa parte, optamos pela noção de contrato para, primeiro, manter nossa coerência teórica e, em segundo lugar, porque Greimas e Courtés apresentam a definição de contrato, em semiótica, como uma relação intersubjetiva que pode modificar o estatuto dos sujeitos em presença. Além disso, eles também afirmam que o contrato implícito é, de um lado, a criação de uma expectativa para ações futuras e, de outro, uma coerção sobre a liberdade do indivíduo (s/d: 84).
} 


\section{Resumo da lei}

A lei $n-818$, composta por 46 artigos, foi publicada em 18 de setembro de 1949 (assinada pelo então presidente Eurico Gaspar Dutra). Basicamente, a lei regula a aquisição, a perda e a reaquisição da nacionalidade, tanto de imigrantes como de brasileiros natos, além de legislar sobre a perda dos direitos políticos. A questão dos imigrantes está focada, sobretudo, nas seções que tratam da naturalização, das condições para adquiri-la e das infrações que levam o imigrante naturalizado a perdê-la.

A lei começa definindo sua concepção de brasileiro. Os dois primeiros itens do artigo $1^{\circ}$ dizem, respectivamente, que é brasileiro aquele que nasce no Brasil (mesmo sendo filho de estrangeiros) ou quem é filho de brasileiros nascido no exterior. Além disso, são considerados brasileiros os que obtiveram a nacionalidade brasileira por meio do artigo 69 da Constituição de $1891^{76}$, assim como os que obtêm a naturalização segundo os requisitos previstos em lei.

A possibilidade de se escolher ou não a nacionalidade brasileira também é regulamentada por essa lei. Essa parte está detalhada nos artigos $2^{\circ}$ ao $5^{\circ} \mathrm{e}$ se referem tanto ao filho de estrangeiro ou estrangeira com um cidadão brasileiro como ao filho de brasileiros nascido no exterior.

O 6ํatigo trata da "nacionalidade brasileira declarada juridicamente". Essa forma de nacionalidade se refere aos estrangeiros que adquiriram a naturalização até o dia 16 de julho de 1934 (baseados no artigo já citado da

\footnotetext{
${ }^{76}$ Citamos nominalmente o artigo 69 da Constituição de 1891, mencionado na presente lei:

“Art 69 - São cidadãos brasileiros:

$1^{\circ}$ ) os nascidos no Brasil, ainda que de pai estrangeiro, não, residindo este a serviço de sua nação;

$2^{\circ}$ ) os filhos de pai brasileiro e os ilegítimos de mãe brasileira, nascidos em país estrangeiro, se estabelecerem domicílio na República;

$3^{\circ}$ ) os filhos de pai brasileiro, que estiver em outro país ao serviço da República, embora nela não venham domiciliar-se;

$4^{\circ}$ ) os estrangeiros, que achando-se no Brasil aos 15 de novembro de 1889, não declararem, dentro em seis meses depois de entrar em vigor a Constituição, o ânimo de conservar a nacionalidade de origem;

$5^{\circ}$ ) os estrangeiros que possuírem bens imóveis no Brasil e forem casados com brasileiros ou tiverem filhos brasileiros contanto que residam no Brasil, salvo se manifestarem a intenção de não mudar de nacionalidade;

$6^{\circ}$ ) os estrangeiros por outro modo naturalizados".

O $4^{\circ}$ item desse artigo se baseia no Decreto 58-A, de 1889, que determinou a naturalização de todo estrangeiro residente no país até o momento da Proclamação da República, salvo os casos contrários expressos por cada estrangeiro desejoso de manter sua nacionalidade (Dal Ri, 2010: 18-19).
} 
Constituição de 1891). O artigo $6^{\circ}$ ainda afirma que todos os naturalizados até 1934 têm direito a solicitar o título declaratório ${ }^{77}$.

O processo de naturalização propriamente dito é tratado nos artigos $7^{\circ}$ ao 18. Dentre esses artigos, o $8^{\circ}$ estabelece os critérios necessários para o estrangeiro solicitar a naturalização. Veremos, com mais detalhes, esses itens em nossa análise.

O prazo de cinco anos de residência no país (como pré-requisito para a naturalização) pode ser reduzido em algumas situações, conforme as estipuladas pelo artigo 9: ser proprietário ou ter filho nascido no Brasil, entre outras exceções. $\mathrm{O}$ artigo 10 detalha os procedimentos burocráticos pelos quais o estrangeiro deve passar para solicitar o início do seu processo de naturalização. Ainda está prevista a possibilidade de instituição de um procurador, no caso do estrangeiro ser português e analfabeto.

$\mathrm{O}$ artigo 11 se refere à naturalização das mulheres estrangeiras que se casaram com diplomatas brasileiros. Do artigo 12 ao 15 , a lei trata dos detalhes burocráticos do pedido de naturalização, que passa por diferentes instâncias do Estado brasileiro até sua aprovação e a emissão da certidão de naturalização.

A entrega da certidão está regulamentada no artigo 16. O artigo 17 permite a qualquer brasileiro impugnar o pedido de naturalização, desde que seja feita com base em argumentos plausíveis. $O$ artigo 18 regulamenta a impossibilidade de se entregar a certidão quando há alguma mudança nas condições do requerente que conflitam com os critérios estabelecidos de naturalização.

Os efeitos da naturalização são tratados nos artigos 19 a 21. A lei declara, assim, que a naturalização só tem validade a partir da entrega da certidão ao requerente e não se estende ao cônjuge ou aos filhos do solicitante.

A perda da nacionalidade brasileira é tratada entre os artigos 22 a 34 . Essa perda não se aplica somente aos estrangeiros naturalizados, mas também aos brasileiros. $\mathrm{Na}$ análise desses artigos, retomaremos os detalhes que levam à perda da nacionalidade.

\footnotetext{
77 O título declaratório de cidadão brasileiro foi instituído pela Constituição de 1891. Esse título foi concedido a todos os imigrantes que se naturalizaram por meio dos incisos $4^{\circ}$ e $5^{\circ}$ do artigo citado na nota anterior. O título se diferenciava da carta de naturalização, que era concedida aos naturalizados por outros meios (Dal Ri, 2010: 29).
} 
O artigo 35 determina que 0 ato de naturalização se torna nulo se comprovada "a falsidade ideológica ou material de qualquer dos requisitos exigidos pelos artigos $8^{\circ}$ e 90". A possibilidade de readquirir a nacionalidade brasileira perdida é tratada nos artigos 36 e 37 . Também trataremos esses dois artigos em detalhes na nossa análise.

A definição dos direitos políticos, assim como sua perda e sua reaquisição, é tratada nos artigos 38, 39 e 40. O artigo 39 afirma que a perda do direito político somente pode ocorrer nos casos previstos no artigo 135 (parágrafos $1^{\circ}$ e $2^{\circ}$ ) da Constituição Federal ${ }^{78}$.

Do artigo 42 ao 46, a lei descreve detalhes burocráticos referentes aos pedidos de naturalização, tais como a criação de livros de registros, os trâmites de comunicação sobre a perda e a aquisição da nacionalidade entre diferentes instâncias administrativas do Estado brasileiro, assim como a data de início da lei. Por fim, são mencionadas todas as outras leis revogadas a partir da publicação da lei 818.

Passemos, então, para o principal tema da presente lei: a definição da nacionalidade brasileira.

\section{O ser brasileiro no discurso jurídico}

Ao nascer, um indivíduo não apenas ganha um nome próprio e um sobrenome, mas também denominações que remetem à sua origem geográfica (cidade, região ou estado da federação) e, obviamente, uma nacionalidade. Tem-se um nome próprio para se diferenciar dos demais membros da família, um gentílico para indicar a qual região ou cidade pertence e uma nacionalidade que indica em qual país se nasceu. A nacionalidade é, assim, uma dentre outras formas de identidade que perpassa um indivíduo.

\footnotetext{
${ }^{78}$ Segue abaixo a citação do referido artigo da Constituição de 1946:

“Art 135 - Só se suspendem ou perdem es direitos políticos nos casos deste artigo.

$\S 1^{\circ}$ - Suspendem-se:

I - por incapacidade civil absoluta;

II - por condenação criminal, enquanto durarem os seus efeitos.

$\S 2^{\circ}$ - Perdem-se:

I - nos casos estabelecidos no art. 130;

II - pela recusa prevista no art. $141, \S 8^{\circ}$;

III - pela aceitação de título nobiliário ou condecoração estrangeira que importe restrição de direito ou dever perante o Estado".
} 
A nacionalidade pode ser considerada como um contrato, imposto automaticamente, entre um destinador-Estado e um sujeito-cidadão que envolve a modalidade do /ser/ desse sujeito, que já surge em conjunção com o valor descritivo "nacionalidade" e atribui a ele o papel temático de "brasileiro". A diferença entre esse contrato de nacionalidade e outros contratos (enquanto um conceito semiótico) está centrada na quase ausência de manipulação, uma vez que a nacionalidade é atribuída automaticamente no momento em que um indivíduo nasce em um determinado país. Podemos, assim, pensar que esse contrato de nacionalidade é "inato", pois quem nasce no Brasil (ou em um determinado país) não tem como recusá-lo no momento mesmo em que o recebe.

Há também outra forma de se ter a nacionalidade brasileira. Essa outra maneira tem como base "herdar" o contrato de nacionalidade de ao menos um dos pais. Dessa maneira, pode-se ter uma nacionalidade "provisória" que será aceita ou recusada quando o indivíduo atinge a maioridade.

Essas não são as únicas formas de se ter o papel temático "brasileiro". Como veremos adiante, a naturalização envolve uma transformação do estrangeiro, que passa a ser, no caso, brasileiro ao aceitar um novo contrato com a nação brasileira e ao abandonar o antigo contrato com sua nação de origem. Em oposição ao contrato de nacionalidade "inato", temos, assim, um contrato de nacionalidade "adquirido" por meio da naturalização. Essas duas formas de nacionalidade estão previstas pela lei analisada, como podemos observar abaixo:

Art. 1 São brasileiros:

I - os nascidos no Brasil, ainda que de pais estrangeiros, desde que não residam estes a serviço de seu país;

II - os filhos de brasileiro ou brasileira, nascidos no estrangeiro, se os pais estiverem a serviço do Brasil, ou, não o estando, se vierem residir no país. Neste caso, atingida a maioridade, deverão, para conservar a nacionalidade brasileira, optar por ela dentro em quatro anos;

III - os que adquiriram a nacionalidade brasileira, nos termos do artigo 69, ns. 4 e 5, da Constituição de 24 de fevereiro de 1891;

IV - os naturalizados, pela forma estabelecida em lei.

A partir das definições de "brasileiro", apresentadas pelo artigo acima, podemos pensar em algumas questões sobre o /ser-brasileiro/. No item I, vemos que o contrato de nacionalidade entre Estado e indivíduo ocorre no ato 
mesmo em que este indivíduo nasce no país, independente da origem de seus pais (mas com a ressalva em relação à função que eles exercem no país: o de não estar em outro programa narrativo que não seja o do próprio Estado brasileiro). O espaço em que esse indivíduo nasce passa a ser, então, determinante para o estabelecimento do contrato que atribui a nacionalidade brasileira a ele. Esse indivíduo é então automaticamente considerado brasileiro porque o contrato é instituído pelo espaço em que ele nasce. Sendo o espaço o elemento fundador desse contrato, a quase ausência de intencionalidade naturaliza uma questão cultural como o nacionalismo. Dessa forma, uma dimensão cultural (porque jurídica), como a de possuir determinada nacionalidade, é revestida por efeitos de natureza, ou seja, de uma cultura naturalizada.

No item II, não é mais o espaço o elemento determinante para atribuição da nacionalidade, mas sim a nacionalidade dos pais. Dessa forma, o espaço dá lugar à consanguinidade, isto é, ao fato de os pais do indivíduo poderem atribuir um papel temático a esse sujeito (o de ser brasileiro). Pode-se pensar, então, que a nacionalidade, nesse caso, é uma doação de sentidos dada por outros sujeitos (os pais) e, no caso da lei, uma nacionalidade que pode ser conservada (ou não), se o sujeito desejar e cumprir certas exigências previstas em lei. Entendemos que os itens I e II, acima mencionados, se referem ao contrato "inato" 79 a que nos referimos anteriormente.

Existe ainda outra forma de se ter a nacionalidade brasileira, conforme podemos observar nos itens III e IV do artigo $1^{\circ}$. Esses dois itens se referem ao processo de naturalização do estrangeiro que vive no Brasil. Assim, temos dois tipos de contrato a respeito do /ser-brasileiro/: um contrato baseado em uma dimensão natural (espaço, sangue), sem a presença da intencionalidade, e outro contrato predominantemente "cultural", no sentido de que a nacionalidade pode ser adquirida. O caráter "não natural" da naturalização (o que não deixa de ser uma contradição de termos) vai se desdobrar, no discurso analisado, em uma série de etapas para sua efetiva realização.

\footnotetext{
${ }^{79}$ Segundo Mello, o universo jurídico distingue dois tipos de nacionalidade: a originária e a adquirida (2002: 956). Optamos por usar o termo "inato" para a nacionalidade originária por entendermos que ela se opõe melhor ao termo "adquirido".
} 
O ato de naturalização é, como dissemos, um novo contrato estabelecido entre o destinatário-estrangeiro e o destinador-Estado. Ao mesmo tempo em que esse contrato é estabelecido, outros dois são desfeitos: aquele que o estrangeiro tinha com seu país de origem e outro que ele mantinha com o próprio Estado brasileiro e que dava a ele a condição de estrangeiro no país.

Ao contrário da nacionalidade obtida ao nascer, que não pressupõe uma vontade, mas uma causalidade "natural", o ato de naturalização é, em certa medida, um ato de vontade (/querer-ser/) ou de interesse (/querer-ser/ para /poder-ser/ e /poder-fazer/) do estrangeiro. Nesse caso, o /querer-ser/ do estrangeiro pode, eventualmente, suplantar um esquema manipulatório do destinador (enquanto um actante "externo" ao sujeito). Em outras palavras, entendemos que a vontade e o interesse do estrangeiro em se naturalizar ocorre, em grande parte dos casos, como uma automanipulação que o leva a enfrentar todo o percurso burocrático previsto pela lei para se tornar brasileiro.

Assim, examinaremos como a lei organiza as etapas de naturalização no presente discurso. A primeira é justamente a questão da vontade do estrangeiro em se tornar, no caso, brasileiro. Isso não significa que ao sujeitoestrangeiro seja permitida a conjunção completa e livre de dificuldades apenas pela motivação orientada por seu /querer/. Como já dissemos, uma série de exigências são colocadas para se comprovar a competência modal necessária, ao final do percurso, para ser reconhecido como um brasileiro.

Antes de examinarmos o percurso da naturalização, veremos como a lei organiza a possibilidade de escolha da nacionalidade brasileira para o filho de um estrangeiro nascido no Brasil e para o filho de brasileiros nascido no exterior.

\section{Das opções sobre a nacionalidade}

Além da nacionalidade brasileira atribuída ao nascer no país ou da nacionalidade adquirida por meio da naturalização, a lei analisada apresenta outras possibilidades de se obter a nacionalidade brasileira. Veremos, nesta seção, como se organiza na lei a escolha da nacionalidade brasileira, assim como apresentaremos a organização de todas as formas de se ter a nacionalidade brasileira construídas pela lei. 
Há duas situações distintas previstas pela lei (artigos $2^{\circ}$ e $4^{\circ}$ ) sobre a possibilidade de se optar pela nacionalidade brasileira: a) quando um dos pais for estrangeiro (e o outro, brasileiro), o filho, nascido no Brasil, pode solicitar a nacionalidade conforme o artigo 129 da Constituição Federal; b) quando filho de brasileiros nascido no exterior (e cujos pais não estão a serviço do governo brasileiro), ao retornar ao país, pode apresentar os documentos necessários para requerer a nacionalidade brasileira em até quatro anos após a sua maioridade. Ambas situações foram mencionadas rapidamente na primeira seção desta análise. Veremos agora quais as possibilidades que a lei prevê em relação à aquisição da nacionalidade brasileira. Para facilitar a análise, citamos o artigo $2^{\circ}$, que trata do primeiro caso:

Art $2^{\circ}$ Quando um dos pais for estrangeiro, residente no Brasil a serviço de seu governo, e o outro for brasileiro, o filho, aqui nascido, poderá optar pela nacionalidade brasileira, na forma do art. 129 , no II, da Constituição Federal ${ }^{80}$.

Vemos que o artigo acima mobiliza, semanticamente, a questão espacial (nascer no Brasil), ao mesmo tempo em que atribui a consanguinidade como uma forma de definição de um sujeito que é, então, provisoriamente brasileiro ${ }^{81}$. Dessa maneira, o sujeito do primeiro caso não é completamente estrangeiro, já que nasceu no Brasil e tem um dos pais brasileiro, mas ao mesmo tempo ele não é totalmente brasileiro, já que há um traço de "estrangeiridade" em sua constituição (advinda de um de seus pais). Por isso, esse sujeito apresenta uma condição peculiar construída discursivamente, segundo a qual ele pode optar pela nacionalidade brasileira ou, algo que fica implícito no artigo, escolher a nacionalidade de origem do pai ou da mãe pais estrangeiros. De qualquer maneira, o importante a se reter nessa questão é a situação "provisória" desse sujeito quanto à sua nacionalidade: é um brasileiro

\footnotetext{
${ }^{80}$ Citamos o artigo referido da Constituição de 1946:

"Art 129 - São brasileiros:

I - os nascidos no Brasil, ainda que de pais estrangeiros, não residindo estes a serviço do seu país;

II - os filhos de brasileiro ou brasileira, nascidos no estrangeiro, se os pais estiverem a serviço do Brasil, ou, não o estando, se vierem residir no País. Neste caso, atingida a maioridade, deverão, para conservar a nacionalidade brasileira, optar por ela, dentro em quatro anos;

III - os que adquiriram a nacionalidade brasileira nos termos do art. $69, \mathrm{n}^{\text {os }}$ IV e V, da Constituição de 24 de fevereiro de 1891;

IV - os naturalizados pela forma que a lei estabelecer, exigidas aos portugueses apenas residência no País por um ano ininterrupto, idoneidade moral e sanidade física".

${ }^{81}$ Segundo Mello, "o Brasil adota o 'jus soli' tradicionalmente, mas atualmente são tantas as exceções em favor do ‘jus sanguinis’ que se pode dizer que adotamos o sistema misto” (2002: 957).
} 
"incompleto" que deve decidir se vai se transformar em um brasileiro "integral" ou se se tornará um estrangeiro em solo brasileiro.

Já o segundo caso, que também mobiliza uma categoria espacial (o nascer fora do país, ou seja, em um "lá"), determina a possibilidade de conversão do filho de brasileiros que possui outra nacionalidade (a do país de seu nascimento), também como um /poder-fazer/ (possibilidade prevista pela lei) que é regido por um /querer-ser/ brasileiro (referente ao desejo de um indivíduo juridicamente estrangeiro em se tornar brasileiro). Da mesma forma que no primeiro caso, a consanguinidade é elemento fundamental para se definir a opção de escolha do sujeito em questão. Há ainda mais uma observação a respeito do espaço: esse indivíduo, filho de brasileiros, só pode vir a se tornar cidadão brasileiro se voltar a residir no país (retornar ao "aqui"), tal como deixa claro o artigo $4^{\circ}$ da lei.

Art $4^{\circ} \mathrm{O}$ filho de brasileiro ou brasileira, nascido no estrangeiro e cujos pais ali não estejam a serviço do Brasil, poderá, após sua chegada ao país, para nele residir, requerer ao Juiz de Direito de seu domicílio, se transcreva, no Registro Civil, o termo de nascimento, fazendo-se constar deste e das respectivas certidões que o mesmo só valerá como prova da nacionalidade brasileira até quatro anos depois de atingida a maioridade.

Podemos observar, pela lei, que há quatro possibilidades de se possuir a nacionalidade brasileira. A diferença entre elas está baseada em dois aspectos: no espaço e nos pais. É a combinação desses aspectos que determina o modo de relação do sujeito com a nacionalidade brasileira (completa ou parcial) e os percursos que ele deve percorrer para se tornar um brasileiro pleno. Por tudo o que foi exposto, é possível propor um quadrado semiótica para explicitar as relações organizadas por essa lei entre o brasileiro e o estrangeiro, assim como essas duas outras categorias "intermediárias" de indivíduo apresentadas acima: 


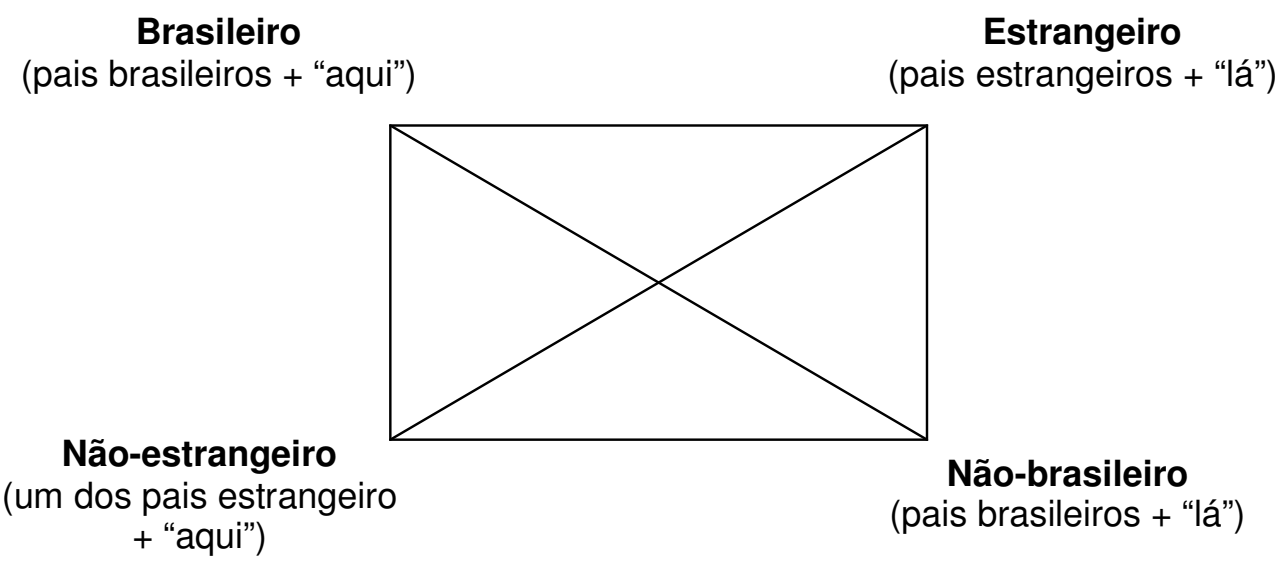

O termo "brasileiro" é central nesse quadrado porque ele serve como referência para os outros três termos, na medida em que os demais podem ir em sua direção. Vemos, por meio da presente lei, que os termos subcontrários (não-estrangeiro e não-brasileiro) apresentam menos exigências burocráticas, como mostram os artigos $2^{\circ}$ e $4^{\circ}$, enquanto o termo contrário ("estrangeiro") apresenta todo um percurso burocrático que será analisado a seguir.

A naturalização é, assim, o percurso com o maior número de etapas. Mas, antes mesmo de o estrangeiro solicitar a naturalização, ele precisa mostrar certas características, exigidas pela lei, para se tornar brasileiro. Passemos, então, para a análise dos critérios estabelecidos em lei e do percurso burocrático necessários para um estrangeiro conseguir sua naturalização.

\section{A naturalização: da organização modal aos percursos narrativos}

Como dissemos acima, o primeiro movimento em direção à naturalização é a vontade ou o interesse do estrangeiro em transformar seu /ser/, adquirindo um novo contrato relativo à nacionalidade ao mesmo tempo em que abandona os contratos anteriores (o de sua nacionalidade de origem e o de ser imigrante/estrangeiro no Brasil). Mas o desejo do estrangeiro não é suficiente para ele conquistar a nova nacionalidade. Veremos, nesta seção, quais as características necessárias e qual o percurso que ele deve percorrer para chegar ao reconhecimento de sua transformação por parte do Estado brasileiro. 
Em um plano mais geral, a lei mostra a seguinte operação: em uma totalidade, como a do "imigrante no Brasil", aplica-se a triagem ${ }^{82}$ (cujos critérios de separação são os descritos abaixo para se obter a naturalização) para se criar um novo conjunto de imigrantes dotados dessas características ("os imigrantes passíveis de se naturalizarem”). Em seguida, projeta-se a mistura ${ }^{83}$ para os imigrantes desejosos de se tornarem brasileiros e, assim, eles passam a fazer parte da totalidade "nação brasileira" quando obtêm a naturalização.

Para adquirir a naturalização, o sujeito-estrangeiro deve primeiramente apresentar, além de sua vontade ou de seu interesse, as características desejadas pela lei (como um reflexo da vontade do Estado) para poder passar por algumas provas, que servem para avaliar sua competência enquanto sujeito. As características explicitadas pela lei mostram a necessidade de uma sanção cognitiva prévia, enquanto uma forma de reconhecimento da competência do sujeito-estrangeiro, anterior mesmo ao seu pedido de naturalização. Assim, o estrangeiro que deseja se transformar em brasileiro deve apresentar características e percursos narrativos anteriores ao próprio processo de naturalização. Se ele não apresentar essas características, o pedido de naturalização fica estacionado nesse estágio de "vontade" do estrangeiro, não podendo, assim, prosseguir:

Art 8 São condições para a naturalização:

I - capacidade civil do naturalizando, segundo a lei brasileira;

II - residência contínua no território nacional pelo prazo mínimo de cinco anos, imediatamente anteriores ao pedido de naturalização;

III - ler e escrever a língua portuguesa, levada em conta a condição do naturalizando;

IV - exercício de profissão ou posse de bens suficientes à manutenção própria e da família;

$\mathrm{V}$ - bom procedimento;

VI - ausência de pronúncia ou condenação no Brasil, por crime cuja pena seja superior a um ano de prisão;

VII - sanidade física.

$\S 11^{\circ}$ Aos portugueses não se exigirá o requisito do $\mathrm{n}^{\circ} \mathrm{IV}$ e, quando aos dos

ns. II e III, bastará a residência ininterrupta durante um ano e o uso adequado da língua portuguesa.

$\S 2^{\circ}$ Não se exigirá a prova de sanidade física a nenhum estrangeiro, quando o prazo de residência for superior a um ano.

\footnotetext{
${ }^{82}$ A triagem é o operador responsável pelo regime de exclusão de grandezas dotadas de sentido. Em outras palavras, a triagem separa as grandezas para a formação do exclusivo (Fontanille e Zilberberg, 2001: 29).

${ }^{83}$ Em oposição à triagem, o operador mistura produz, como o próprio nome do conceito aponta, para o intercâmbio entre diferentes grandezas dotadas de sentido (Fontanille e Zilberberg, 2001: 29).
} 
No item I, fala-se na "capacidade civil do naturalizando, segundo a lei brasileira" ${ }^{44}$. O sujeito que deseja solicitar a naturalização deve ter, segundo a lei, autonomia jurídica para realizar sua vontade. Se ele for considerado juridicamente incapaz, como, por exemplo, ser menor de idade ou apresentar algum tipo de deficiência mental, ele já está limitado em relação à realização de sua vontade. Dessa forma, se o sujeito for civilmente incapaz, ele não pode naturalizar-se. De antemão, ele é sancionado como um sujeito incompetente. Essa sanção, de certa forma, incide sobre o /ser/ do estrangeiro que deseja se naturalizar, pois ele não tem (ou ainda não apresenta) a competência (/nãopoder-ser/) necessária para se naturalizar.

$O$ item II se refere à manutenção de um determinado tempo de residência em território nacional, anterior ao pedido de naturalização. Em outras palavras, o imigrante que deseja a naturalização precisa provar que já participa dos programas narrativos da sociedade brasileira. Esse item mostra que somente ao estrangeiro que está no país com o visto permanente (de longa data) possui condições de tentar solicitar a naturalização. Dessa forma, a lei restringe a possibilidade de naturalização aos estrangeiros que têm visto permanente e que podem ser considerados imigrantes. Já o item III se refere principalmente à modalidade do /saber-fazer/: a questão linguística (que será tratada adiante).

O item IV trata da competência que esse sujeito deve possuir. Em outras palavras, ele precisa demonstrar sua capacidade para o trabalho, ou seja, ter o papel temático de "trabalhador". Esse papel temático pode ser substituído por um /ter/ e por um /poder-ter/, pois o sujeito que deseja naturalizar-se pode mostrar que possui um bom patrimônio. A lei constrói, assim, as figuras do

\footnotetext{
${ }^{84}$ Capacidade Civil é uma das maneiras de se referir à Capacidade de Direito. Essa capacidade se refere ao potencial de cada indivíduo em praticar atos na vida cotidiana (civil). Como todo indivíduo, em princípio, é considerado capaz na vida civil, a lei e seus estudiosos discutem, principalmente, as características que determinam a incapacidade civil de um sujeito. A incapacidade civil é, geralmente, dividida em absoluta e relativa. Na incapacidade absoluta, a vontade do indivíduo não é nunca considerada válida pelas limitações que ele possui. Já na incapacidade relativa, a vontade do indivíduo é respeitada, mas necessita de autorização de pessoa capacitada para ser executada (Fiuza, 2008: 128-130). Segundo o Código Civil de 1916, vigente naquele momento, os incapazes apresentam as seguintes características:

"Art. $5^{\mathrm{o}}$ São absolutamente incapazes de exercer pessoalmente os atos da vida civil:

I - os menores de 16 (dezesseis) anos;

II - os loucos de todo o gênero;

III - os surdos-mudos, que não puderem exprimir a sua vontade;

IV - os ausentes, declarados tais por ato do juiz".
} 
"trabalhador" e do "homem de posses" como condições para que o sujeito obtenha a desejada naturalização.

A questão do "bom procedimento" pode ser entendida modalmente como /saber-fazer/, ou seja, saber se comportar como um bom cidadão, sem condenações na justiça, o que é complementado pelo item VI, ou seja, sem sanções negativas anteriores. A "sanidade física" é a do /poder-fazer/, isto é, a de ter capacidade física para o trabalho e também a do /poder-ser/ saudável para que esse sujeito não se configure como uma ameaça à saúde pública brasileira ${ }^{85}$ e não dê gastos ao Estado brasileiro.

Modalmente, o imigrante que pode tornar-se brasileiro deve estar revestido das modalidades do /saber-ser/ ("bom cidadão"), do /saber-fazer/ ("trabalhador", "bom procedimento", "ler e escrever em português"), do /poderter/ ("homem de posses") e do /poder-ser/ ("capacidade civil"). Em resumo, o imigrante que deseja naturalizar-se, deve mostrar que se comporta como um brasileiro.

Somente com essas características, o estrangeiro que deseja se naturalizar pode então ser um candidato ao posto de cidadão brasileiro. Dessa maneira, ele se juntaria ao grupo considerado ideal pela lei: bom cidadão, sem problemas na justiça, trabalhador (ao menos com capacidade para o trabalho), dotado de profissão e/ou patrimônio e usuário da língua portuguesa. Em outras palavras, as características do imigrante que quer se naturalizar exigidas pela lei remetem à ideia do cidadão brasileiro ideal (“o bom brasileiro").

Como vimos, a lei mostra claramente que o estrangeiro que deseja se naturalizar deve apresentar a competência do /saber-ler/ e do /saber-escrever/ em língua portuguesa. Ele deve provar sua competência gramatical diante do juiz, que julga sua capacidade ao vê-lo, no momento mesmo do julgamento, escrever e ler um trecho da Constituição:

Art 16. A entrega do decreto constará de termo lavrado no livro de audiências e assinado pelo Juiz e pelo naturalizando, devendo este:

a) demonstrar que sabe ler e escrever a língua portuguesa, segundo a sua condição, pela leitura de trechos da Constituição Federal;

b) declarar expressamente que renuncia à nacionalidade anterior;

c) assumir o compromisso de bem cumprir os deveres de brasileiro.

\footnotetext{
${ }^{85}$ Alongando um pouco a interpretação, pode-se pensar na funcionalidade ou na utilidade social que um imigrante naturalizado pode ter para a sociedade por conta de sua capacidade física para o trabalho.
} 
$\S 1^{\circ}$ Ao naturalizando de nacionalidade portuguesa, exigir-se-á, quanto ao inciso a, apenas a comprovação do uso adequado da língua.

$\S 2^{\circ}$ Será anotada, no decreto e comunicada, assim ao Ministério da Justiça e Negócios Interiores, como a repartição encarregada do recrutamento militar, a data da entrega, e dele também constará a declaração de haver sido prestado o compromisso e lavrado o termo.

$\S 3^{\circ}$ O decreto ficará sem efeito, salvo motivo de força maior devidamente comprovado, se a entrega não for solicitada no prazo de seis ou de dezoito meses, contados da data da publicação, conforme o naturalizando residir no Distrito Federal, ou noutro ponto do território brasileiro.

$\S 4^{\circ}$ Decorrido qualquer desses prazos, será o decreto devolvido ao Ministro, que, por simples despacho mandará arquivá-lo, anotando-se esta circunstância no respectivo registro.

$\S 5$ Se o naturalizando no curso do processo, mudar de residência, poderá requerer lhe seja efetuada a entrega do decreto no lugar para onde se houver mudado.

É interessante notar que a lei aponta para a condição do imigrante no momento da "prova" de leitura e escrita em língua portuguesa. Dessa forma, parece estar prevista na lei a possibilidade de o imigrante cometer "erros", cabendo ao juiz analisar se o requerente apresenta a competência mínima exigida do idioma português.

$\mathrm{O}$ ato de ler um trecho da Constituição parece carregar duas questões simbólicas mais fortes: de um lado, o discurso jurídico como um padrão da língua nacional; do outro, a Constituição como um discurso padrão e de prestígio, ao menos mais do que as demais formas, já que é o texto máximo de uma nação. Além disso, o uso das práticas de ler e escrever revela o papel da educação formal escolar como critério de avaliação da competência cognitiva do estrangeiro que deseja se tornar brasileiro.

O parágrafo primeiro do artigo acima abre uma exceção para o imigrante português. A lei mostra que o português precisa apenas apresentar sua competência de "falar" a língua portuguesa ${ }^{86}$ (e fica implícito que ele não precisa saber ler e escrever), ao contrário dos imigrantes de outras origens, que devem mostrar sua competência formal no domínio do idioma português. A lei enfatiza o uso linguístico, no caso do imigrante português, em oposição à avaliação do $/$ saber-linguístico $/{ }^{87}$ do imigrante de outras nacionalidades. Podemos, então, pensar que os imigrantes não alfabetizados em português e

\footnotetext{
${ }^{86}$ Embora isso não fique totalmente claro no artigo 16.

87 Comprovado, como dissemos, pela leitura e pela escrita de um trecho da Constituição, texto considerado difícil mesmo para brasileiros. Além disso, a lei não verifica se o estrangeiro entendeu o que leu ou escreveu.
} 
não dominam o padrão formal da língua portuguesa são, de certa forma, impedidos de continuar o processo de naturalização.

O que analisamos até o momento é a organização da competência necessária para o imigrante que deseja se naturalizar. Mas, mesmo dotado de todas as competências modais exigidas pela lei, o imigrante, ainda assim, pode não receber o reconhecimento de sua nova nacionalidade. É preciso, ainda, passar pelo percurso da burocracia nacional, na qual o imigrante deve provar a veracidade de sua condição no Brasil para, no final, receber a sanção positiva necessária para se tornar brasileiro. São os percursos a que chamamos de "burocráticos" que analisaremos a seguir.

Do artigo 10 ao 18, a lei trata das etapas burocráticas pelas quais 0 estrangeiro deve passar para adquirir a sua naturalização. De um modo geral, o estrangeiro realiza toda uma construção veridictória para provar sua competência em relação às exigências previstas pela lei. Essa manipulação (para se "mostrar verdadeiro") não apenas se refere ao momento do julgamento, mas também à obtenção de determinados documentos e comprovantes com os quais o imigrante requerente pode também manipular 0 Estado brasileiro com o intuito de obter o reconhecimento para se tornar brasileiro. Para facilitar a análise, citamos 0 artigo 10 que trata da documentação a ser apresentada:

Art 10. O estrangeiro que pretender naturalizar-se deverá requerê-lo ao Presidente da República, declarando na petição o nome por extenso, nacionalidade, naturalidade, filiação, estado civil, dia, mês e ano de nascimento, profissão e os lugares onde tenha residido anteriormente, aqui ou no estrangeiro.

Parágrafo único. A petição será assinada pelo naturalizando ou, se for português e analfabeto, por procurador com poderes especiais, devendo ter reconhecida a firma a ser instruída com os seguintes documentos:

I - carteira de identidade para estrangeiro;

II - atestado policial de residência continua no Brasil (art. $3^{\circ}, n^{\circ}$ II);

III - atestado policial de bons antecedentes e folha corrida, passados pelos serviços competentes dos lugares do Brasil, onde haja residido;

IV - carteira profissional, diplomas, atestados de associações, sindicatos ou empresas empregadoras (artigo 8ㅜ, no IV);

$\mathrm{V}$ - atestado de sanidade física;

$\mathrm{VI}$ - certidões ou atestados que provem, quando for o caso, as condições do art. 9, ns. I a VII.

Além do requerimento de naturalização endereçado ao Presidente da República (com informações objetivas do estrangeiro, como nome, data de 
nascimento, nacionalidade de origem, etc.), devem ser anexados documentos comprobatórios do tempo de residência no Brasil e também antecedentes criminais, ambos os documentos emitidos pela polícia brasileira. Assim, a polícia brasileira é o primeiro destinador-julgador do estrangeiro que deseja naturalizar-se. O estrangeiro precisa mostrar que cumpre esses requisitos iniciais para obter a sanção cognitiva e, principalmente, pragmática (na forma dos dois documentos comprobatórios: o de residência e o de antecedentes criminais).

O parágrafo único do artigo acima apresenta, ainda, outra exceção para o imigrante português. Esse artigo prevê a possibilidade de o requerente português e analfabeto instituir um procurador para representá-lo. Dessa forma, a lei 818 restringe a possibilidade de imigrantes de outras origens (e também analfabetos em língua portuguesa) se beneficiarem da presença de um procurador que poderia representá-los e explicar a eles o andamento do processo de naturalização.

Reunidos todos os comprovantes (carteira de identidade do estrangeiro, carteira profissional, diplomas, atestados de associações ou sindicatos, atestado de sanidade física e também os antecedentes criminais e os comprovantes de residência), o segundo destinador-julgador pelo qual 0 estrangeiro precisa passar é a Secretaria de Segurança do estado em que ele reside. Cabe, segundo a lei, à Secretaria de Segurança realizar um /fazerinvestigativo/ da vida pregressa do estrangeiro requerente. Somente após esse /fazer-investigativo/, o pedido de naturalização segue para o Ministério da Justiça e Negócios Interiores, caso não tenha nenhum fato que desabone a vontade do imigrante de se tornar brasileiro.

Surge, assim, o terceiro destinador-julgador do imigrante requerente: o Ministério da Justiça e Negócios Interiores, instância que analisa os documentos. Se não for observado nenhum problema na documentação, ou seja, se o estrangeiro for considerado apto a receber a naturalização, o pedido segue para a Presidência da República que ainda tem o poder de publicar ou não o decreto de naturalização do estrangeiro.

Por fim, a última etapa da naturalização é a emissão e a entrega do certificado (sanção pragmática) ao estrangeiro que cumpriu com todas as exigências previstas em lei e teve seu pedido de naturalização aprovado. Mas 
a entrega do certificado só ocorre se o estrangeiro passar pelo último destinador-julgador: o juiz de direito. Para conquistar o certificado, o estrangeiro deve ainda mostrar que sabe ler e escrever em português (/saberfazer/), como já vimos (artigo 16, supra), declarar que renuncia a sua nacionalidade anterior (ou seja, rompe com o contrato anterior) (/querer-nãoser/) e assumir o dever de cumprir os deveres brasileiros (/dever-fazer/) como forma de provar, definitivamente, sua vontade de se tornar brasileiro (/quererser/ e /querer-fazer/). Esquematicamente, apresentamos abaixo os percursos burocráticos pelos quais o imigrante precisa passar:

\begin{tabular}{|c|c|c|c|c|}
\hline & 1a etapa & $2^{\mathbf{a}}$ etapa & $3^{a}$ etapa & 4⿳亠丷厂 etapa \\
\hline$\stackrel{+}{\frac{1}{4}}$ & Polícia brasileira & $\begin{array}{l}\text { Secretaria } \\
\text { Estadual de } \\
\text { Segurança }\end{array}$ & $\begin{array}{l}\text { Ministério da } \\
\text { Justiça e } \\
\text { Negócios } \\
\text { Interiores }\end{array}$ & Juiz de direito \\
\hline 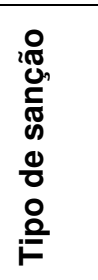 & $\begin{array}{c}\text { Sanção cognitiva / } \\
\text { Sanção pragmática } \\
\text { (atestados) }\end{array}$ & Sanção cognitiva & Sanção cognitiva & $\begin{array}{l}\text { Sanção cognitiva } \\
\text { e sanção } \\
\text { pragmática } \\
\text { (certificado de } \\
\text { naturalização) }\end{array}$ \\
\hline 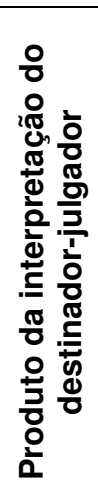 & $\begin{array}{c}\text { Produção de } \\
\text { comprovantes: } \\
\text { atestados de residência } \\
\text { e de antecedentes } \\
\text { criminais do } \\
\text { requerente }^{88}\end{array}$ & $\begin{array}{c}\text { Fazer } \\
\text { investigativo: vida } \\
\text { pregressa do } \\
\text { requerente }\end{array}$ & $\begin{array}{l}\text { Análise de toda a } \\
\text { documentação do } \\
\text { processo de } \\
\text { naturalização }\end{array}$ & $\begin{array}{c}\text { Entrega do } \\
\text { certificado } \\
\text { mediante a } \\
\text { comprovação da } \\
\text { competência } \\
\text { linguística e de } \\
\text { provas sobre a } \\
\text { fidelidade ao } \\
\text { Brasil }\end{array}$ \\
\hline
\end{tabular}

Como mencionamos, cada uma das etapas apresenta uma sanção sobre a competência e o /fazer/ do estrangeiro. Na primeira etapa, há uma sanção cognitiva, que se refere ao reconhecimento de seu "bom comportamento" (pela ausência de crimes), e uma sanção pragmática, que é a

\footnotetext{
${ }^{88}$ Todos os produtos do fazer-interpretativo do destinador-julgador servem, por conseguinte, para a manipulação do sujeito-imigrante em relação ao destinador-julgador seguinte do percurso de naturalização.
} 
emissão dos documentos de residência de antecedentes criminais. Na segunda etapa, há uma sanção cognitiva feita pela Secretaria Estadual de Segurança para verificar se não há qualquer problema na vida pregressa do estrangeiro (e, no seu limite, para examinar se o estrangeiro requerente não é uma possível ameaça ao país). Na terceira etapa há uma nova sanção cognitiva que incide sobre a veracidade dos documentos necessários para solicitar a naturalização apresentados pelo estrangeiro. Por fim, há novamente uma dupla sanção na última etapa: o estrangeiro recebe uma sanção cognitiva (reconhecimento de sua competência para se tornar brasileiro) e uma sanção pragmática (certificado que comprova sua nova nacionalidade) dadas pelo juiz de direito.

Vimos nesta seção que o movimento em direção à naturalização começa com a vontade do imigrante de se transformar em um cidadão brasileiro. Em seguida, o imigrante precisa preencher algumas características exigidas pela lei, antes mesmo de solicitar a naturalização. Dentre as características, o uso adequado (dentro das possibilidades do imigrante) da língua portuguesa é um dos requisitos para ser reconhecido como um cidadão brasileiro, ao menos na modalidade escrita da língua (ler e escrever em português). Como dissemos, o imigrante de qualquer nacionalidade (exceto o português) que não for alfabetizado em língua portuguesa está excluído do processo de naturalização. Uma exceção é feita para o imigrante português, que precisa apenas mostrar que fala português (fato que o dispensa da leitura e da escrita) diante de um juiz.

As exigências para um imigrante adquirir a nacionalidade brasileira podem ser entendidas como uma forma de o Estado evitar a integração de imigrantes "ruins". É justamente por conta das exigências e dos percursos que o Estado brasileiro pode selecionar qual o imigrante apropriado para se tornar brasileiro.

Para se chegar à transformação de sua nacionalidade, na qual o sujeitoimigrante aceita um novo contrato entre ele e o Estado brasileiro, há todo um jogo de manipulação por parte do sujeito-imigrante e de interpretação por parte de diferentes destinadores-julgadores, configurando o que chamamos de percurso "burocrático" da naturalização. Assim, o imigrante que deseja se naturalizar passa por diversas sanções até ser definitivamente reconhecido como um cidadão. É importante mencionar, ainda, que o processo de 
naturalização pode ser extenuante para o imigrante, já que o pedido passa por diversas instâncias burocráticas até chegar a um ministério federal que dá o veredito final para o pedido de naturalização.

A lei, contudo, não apenas trata da aquisição da nacionalidade, mas também prevê as condições de sua perda. Veremos a seguir quais são as situações em que isso pode ocorrer.

\section{A perda da nacionalidade e seu restabelecimento: questões de contrato fiduciário}

O fato de que todo homem tem direito a uma nacionalidade não significa que ele não pode perdê-la. Sendo um contrato entre indivíduo e Estado, a nacionalidade pode ser perdida, segundo certas condições previstas em lei.

A perda da nacionalidade engloba tanto a de brasileiros natos como a de estrangeiros naturalizados. Logo, a perda se aplica tanto ao contrato de nacionalidade brasileira "inato" como ao "adquirido". A lei, assim, trata de dois rompimentos de contrato, ou seja, das exclusões aplicadas a um sujeitobrasileiro ou a um sujeito-naturalizado. Veremos, nesta seção, as duas formas de rompimento do contrato de nacionalidade: a primeira, por opção do cidadão brasileiro; a segunda, por vontade do Estado. Essas duas maneiras de se romper o contrato de nacionalidade são apresentadas no artigo abaixo:

Art 22. Perde a nacionalidade o brasileiro:

I - que, por naturalização voluntária, adquirir outra nacionalidade;

II - que, sem licença do Presidente da República, aceitar, de governo estrangeiro, comissão, emprego ou pensão;

III - que, por sentença judiciária, tiver cancelada a naturalização, por exercer atividade nociva ao interesse nacional.

A perda da nacionalidade, como descrita acima, apresenta diferentes situações envolvendo o brasileiro nato (item I), o estrangeiro naturalizado (item III) e ambos (item II). No caso do item I, o cidadão brasileiro pode perder sua nacionalidade se adquirir a de outro país. Em outras palavras, ao /querer-ser/ cidadão de outro país, o indivíduo também mobiliza o /querer-não-ser/ mais brasileiro. Dessa forma, é por meio de um ato de vontade do indivíduo (querer se auto-excluir/querer-ser de outra nacionalidade) que produz a perda da 
nacionalidade ${ }^{89}$. Nesse caso, podemos entender que o rompimento do contrato de nacionalidade ocorre por meio da vontade do brasileiro nato.

Além disso, há também a possibilidade de o indivíduo perder sua nacionalidade brasileira ao fazer parte de outro programa narrativo, sem o conhecimento prévio do destinador-Estado brasileiro. Nesse caso, a perda da nacionalidade se configura como uma penalidade a esse indivíduo (brasileiro nato ou estrangeiro naturalizado), decretada após a análise, a investigação e a sanção realizadas por outro ator instaurado no discurso (Ministério da Justiça e Negócios Interiores, conforme artigo 23). A perda da nacionalidade, nesse caso, se caracteriza por um rompimento do contrato de nacionalidade por parte do Estado brasileiro, cuja punição decorre de um ato considerado, em termos, uma traição, na medida em que está envolvida a modalidade do /parecer-ser/: o sujeito que trabalha para outro país sem o conhecimento e a autorização do governo brasileiro é desvelado em seu /fazer/ e é punido com a perda da nacionalidade.

No caso do estrangeiro naturalizado, o rompimento do contrato também ocorre pelo lado do Estado brasileiro. O cancelamento da naturalização só pode ser realizado por meio de processo jurídico, cujo destinador-julgador é figurativizado pelo ator juiz. Para que isso ocorra, o sujeito-estrangeiro naturalizado deve ser considerado, em sua ação, um elemento prejudicial à manutenção da grandeza chamada Brasil. Atores distintos podem desencadear a acusação das ações malevolentes do estrangeiro naturalizado: ou o próprio Ministério da Justiça e Negócios Interiores, enquanto representante do governo, ou qualquer cidadão brasileiro, enquanto representante da sociedade nacional, como podemos observar nos artigos abaixo:

Art 24. O processo para cancelamento da naturalização será da atribuição do Juiz de Direito competente para os feitos da União, do domicílio do

\footnotetext{
${ }^{89}$ Segundo Mello, a Dupla Nacionalidade (adquirir outra nacionalidade sem perder a de origem) pode ocorrer nos casos em que há uma divergência entre a legislação de dois países, sobretudo quando um adota o jus soli e o outro, o jus sanguinis. A partir dessa divergência, uma série de problemas são criados, como a questão do serviço militar e a proteção diplomática (2002: 963). Alexandrino e Paulo dizem que, pela lei brasileira, um cidadão brasileiro não perde sua nacionalidade quando há o reconhecimento de nacionalidade originária por outro Estado estrangeiro. É o caso dos descendentes de italianos que adquirem a nacionalidade italiana, que é baseada no jus sanguinis. Outra forma de não se perder a nacionalidade brasileira ao mesmo tempo em que se adquire outra ocorre por meio da naturalização forçada. A naturalização, nesse caso, é considerada forçada porque ela é condição para a permanência do brasileiro no país estrangeiro (Alexandrino e Paulo, 2010: 110-111).
} 
naturalizado, e iniciado mediante solicitação do Ministro da Justiça e Negócios Interiores, ou representação de qualquer pessoa.

Art 25. A representação que deverá mencionar, expressamente, a atividade reputada nociva ao interesse nacional, será dirigida à autoridade policial competente, que mandará instaurar o necessário inquérito.

A duas possibilidades de solicitação de punição acima mencionadas apresentam também percursos distintos. Enquanto o Ministério da Justiça e Negócios Interiores pode fazer uma solicitação direta ao juiz, o cidadão brasileiro deve dirigir-se a uma autoridade policial que vai, assim, instaurar um inquérito que só depois é repassado a um juiz. Em ambos os casos, ocorre um fazer-interpretativo inicial do Ministro da Justiça e do cidadão comum, que percebem alguma irregularidade no sujeito-naturalizado.

Quando o pedido chega ao juiz, é instaurado o processo e o denunciado (estrangeiro naturalizado) é convocado para sua qualificação (apresentação ao juiz de direito e leitura da acusação). Nesse momento, há assim a competição entre o naturalizado-acusado e o Ministério Público para ver quem consegue obter do juiz a aprovação do seu fazer-veridictório. Por fim, o juiz decide se o naturalizado perde ou não sua condição.

Mesmo perdendo a nacionalidade, a lei prevê a possibilidade de reavêla. Assim, o brasileiro que perder sua nacionalidade por ter adquirido outra ou por estar trabalhando para outro Estado nacional pode ainda readquiri-la, segundo o artigo 36 da presente lei. Para readquirir a nacionalidade brasileira, esse sujeito deve partir para um novo percurso, caracterizado principalmente pela prova da renúncia ao programa narrativo do outro Estado nacional ao qual ele estava ligado. Ele deve mostrar que renunciou aos benefícios advindos de proventos ou títulos de outro país e que não está mais em conjunção com objetos-valores de outro destinador para voltar a sua condição de sujeito político brasileiro. Ao mesmo tempo, ele precisa aceitar expressamente as punições que eventualmente o governo brasileiro possa aplicar.

Por intermédio do Ministério das Relações Exteriores, o governo pode analisar e investigar se o requerente realmente renunciou aos benefícios advindos de outro governo (item 2 do artigo 22). Se ficar provado, ainda, que o sujeito adquiriu outra nacionalidade para se livrar das obrigações e deveres de um cidadão brasileiro, a reaquisição é negada. 
Nesta seção, examinamos as formas de perda da nacionalidade, aplicada tanto a brasileiros natos como a estrangeiros naturalizados. Duas são as possibilidades de rompimento do contrato de nacionalidade: de um lado, por vontade do indivíduo; de outro, como uma punição do Estado. Vimos que a perda da nacionalidade por vontade do brasileiro é um processo relativamente simples. Por oposição, há um percurso mais complexo e repleto de investigações e de avaliações em relação ao brasileiro que trabalha para um governo estrangeiro (sem autorização do governo brasileiro) ou ao estrangeiro naturalizado. Além do mais, nesse último caso, vemos que a possibilidade de um cidadão brasileiro poder se tornar um "acusador", que requer o fim do contrato de nacionalidade do estrangeiro com o país, é uma situação não encontrada no caso da perda de nacionalidade de um brasileiro nato. Em tese, qualquer imigrante naturalizado pode ser convocado diante do juiz para ver sua condição de brasileiro ser mantida ou revogada. Dessa forma, mesmo sendo considerado um brasileiro pleno, por contar com os mesmos direitos e deveres de um cidadão nacional, o estrangeiro naturalizado enfrenta algumas possibilidades a mais de rompimento de contrato como uma forma de punição registrada em lei.

\section{Considerações parciais}

Vimos na lei no 818 alguns traços ligados, sobremaneira, à questão identitária que a nacionalidade envolve. A partir da construção de quatro formas de relação de um sujeito com a nacionalidade brasileira, pudemos observar como se estabeleceram os diferentes percursos narrativos para se entrar em conjunção completa com a nacionalidade brasileira.

As duas primeiras formas de brasileiro "provisório" (nascido no Brasil, mas com um dos pais estrangeiro, ou nascido no exterior e com país brasileiros) não apresentam grandes complicações burocráticas para adquirir, em definitivo, a nacionalidade brasileira. A lei não apresenta nenhuma exigência para conceder definitivamente a nacionalidade brasileira nesses casos, pois há uma prevalência da nacionalidade brasileira de ao menos um dos pais no momento de atribuir a nacionalidade a seu filho. Em outras 
palavras, nesse caso, o sujeito pode "herdar" definitivamente o contrato de nacionalidade de seus pais (ou de um deles) se assim desejar.

$O$ estrangeiro que deseja se naturalizar brasileiro precisa mostrar algumas características definidas pela lei. Ele deve ser, então, um bom cidadão, sem problemas na justiça, trabalhador ou possuidor de patrimônio e alfabetizado. A representação do estrangeiro construída pela lei está próxima à imagem idealizada do "bom cidadão brasileiro", que cumpre seus deveres e que não apresenta qualquer tipo de problema ou de incapacidade para o trabalho. Assim, só podem se tornar brasileiros os estrangeiros que conseguem, de alguma forma, contribuir para o desenvolvimento do país por meio de seu /fazer/.

Em especial, o caso do estrangeiro nos chama a atenção pelas inúmeras etapas burocráticas pelas quais ele precisa passar para poder se tornar brasileiro. Assim, o sujeito-estrangeiro pode transformar sua nacionalidade, mas não sem antes passar por uma série de sanções que interpretam sua competência e a veracidade de seus documentos. $O$ conhecimento da língua portuguesa, dentre outros elementos, parece ser fundamental para ele se tornar brasileiro. O estrangeiro precisa provar sua competência linguística ao ler e escrever trechos da Constituição diante do juiz que analisa seu caso. Mesmo sendo possível cometer "erros", o caso do estrangeiro difere um pouco do português analfabeto porque este deve apenas mostrar que fala a língua portuguesa enquanto aquele precisa apresentar um domínio mais formal do idioma (pois se pressupõe que as modalidades de ler e escrever em língua portuguesa foram aprendidas na escola). Por essa razão, podemos ver que a lei exclui, da possibilidade de se naturalizar, os imigrantes que não são alfabetizados em língua portuguesa.

Entendemos que os percursos burocráticos para a aquisição da nacionalidade brasileira têm, em seu fundo, a preocupação com a preservação da segurança nacional, da ordem pública e da saúde coletiva. Assim, a lei permite ao Estado separar os imigrantes desejáveis dos indesejáveis ao estabelecer os critérios necessários para naturalização e o percurso burocrático para adquiri-la, uma vez que o imigrante passa por diversas sanções de sua competência. 
A presente lei trata também dos brasileiros que, de alguma forma, se desviaram dos percursos pré-estabelecidos por seu contrato de "cidadão brasileiro", sendo previstas igualmente punições para essas infrações. As infrações podem ir da mudança de nacionalidade de um brasileiro nato até a "traição" (por trabalhar para outro Estado nacional sem o conhecimento do governo brasileiro). No caso da perda da naturalização, todo um percurso burocrático é igualmente instaurado para investigar qual o ato infracional cometido pelo naturalizado. Nesse aspecto, o início da investigação pode começar por uma acusação feita por qualquer cidadão brasileiro ou pelo Ministério da Justiça. Hipoteticamente, um imigrante naturalizado pode, a qualquer momento, ser acusado de ameaça ao país e, consequentemente, perder sua naturalização.

A seguir, veremos outra lei que trata dos estrangeiros no Brasil, já na década de 1980. Ainda compararemos alguns pontos em comum da lei que acabamos de examinar, sobretudo quanto à questão da naturalização e das formas de exclusão do estrangeiro.

\section{3. $O$ estatuto do estrangeiro}

\section{Introdução}

A condição jurídica do estrangeiro é um dos tópicos tratados pelo Direito Internacional. De um modo geral, as leis internacionais determinam que o estrangeiro possua os mesmos direitos de um cidadão nato e, ao mesmo tempo, algumas limitações de atuação. Mello utiliza o seguinte exemplo: o estrangeiro não goza de direitos políticos no país onde não é cidadão, mas o estrangeiro é equiparado ao cidadão nato quando se trata da dimensão econômica do país (o estrangeiro, assim, não pode ser sobretaxado em relação ao cidadão nato) (Mello, 2002: 1020).

Nesta seção, analisaremos a lei 6.815, também conhecida como Estatuto do Estrangeiro. Essa lei foi criada para regulamentar a situação jurídica do estrangeiro no Brasil. O país teve antes outro Estatuto do Estrangeiro (Decreto-lei 941, de 13 de outubro de 1969), substituído pela lei 6.815 , que continua valendo até os dias atuais. 
Podemos pensar que o estrangeiro se distingue de outras formas de alteridade semelhantes, como o imigrante, o turista e o refugiado, entre outras, por ter um sentido mais geral do que as demais. Prova disso é que podemos pensar que o termo "estrangeiro" mantém uma relação hiperônima com os demais termos pelo seguinte raciocínio: um imigrante é sempre estrangeiro, mas um estrangeiro nem sempre é um imigrante. Dessa forma, a lei 6.815 não trata apenas dos imigrantes, mas também do turista e do estrangeiro que vem ao país a trabalho por uma empresa estrangeira por um tempo determinado.

Atualmente, o Estatuto do Estrangeiro é foco de discussões para sua revisão. Essas discussões são baseadas no anacronismo da lei que contraria tanto leis internacionais (como a lei sobre os Direitos dos Trabalhadores Migrantes e seus Familiares, aprovada pela ONU) como nacionais.

Conforme afirma Ahuma, o Estatuto do Estrangeiro contraria outras leis, como o Plano Nacional de Direitos Humanos do governo brasileiro e o Estatuto da Criança e do Adolescente. Diz o autor:

\begin{abstract}
Aqueles que não se enquadrarem dentro das exigências da lei são portanto, denominados ilegais ou clandestinos, interferindo no exercício de sua cidadania, negando-lhes direitos básicos, como alugar um imóvel, ser registrado em um emprego, receber assistência médica gratuita. Nestes 27 anos, o Estatuto do Estrangeiro no Brasil feriu irremediavelmente os direitos da criança e do adolescente, impedindo de estudar em escola pública, o próprio estatuto $(E C A)$ foi violado, pois prescrevia a não discriminação entre brasileiros e estrangeiros documentados ou não (Ahuma, 2007: 1).
\end{abstract}

A crítica acima mostra que o Estatuto do Estrangeiro, em certa medida, ficou anacrônico e, por isso, apresenta critérios que estão muito distantes da realidade globalizada de nossos dias. O mesmo autor apresenta algumas propostas de revisão:

1. A partir da ampla mobilização de suas bases, a atuação do serviço pastoral entende que além de uma nova lei de estrangeiros, são necessárias medidas que apontem para uma política, que inclua um tratamento humanitário aos imigrantes em situação irregular no Brasil, com políticas públicas universalizadas. A legislação brasileira pode ser um parâmetro de política imigratória na América Latina.

2. Ratificação da Convenção da ONU sobre os Direitos dos Trabalhadores Migrantes e seus Familiares, aprovada em 18 de dezembro de 1990, depois de uma década de debates no âmbito da ONU - a convenção entrou em vigor em 2003 e em 1996 o Brasil já havia incluído em seu plano de direitos humanos o compromisso com a ratificação, mas ainda é o único país do MERCOSUL que não ratificou o compromisso. 
3. O direito a voto aos imigrantes com 3 anos de residência permanente no Brasil através de emenda a Constituição Federal, com a possibilidade de participação nas eleições e nas decisões da administração em âmbito local ou federal.

4. Anistia ampla para os indocumentados - haja vista que a última foi em 1998.

5. Que se amplie a proteção internacional para as pessoas vitimas de qualquer forma de perseguição.

6. Urgência na ratificação do Tratado de Livre Residência garantindo, assim, a livre circulação das pessoas em países do MERCOSUL (Ahuma, 2007: 3).

O Estatuto do Estrangeiro mantém uma série de proibições ao estrangeiro se estabelece no país, tanto no aspecto econômico como na dimensão política. Mas a lei também trata dos direitos do estrangeiro no país, assim como da possibilidade de se naturalizar. Analisaremos como se organizam essas proibições, mas também a naturalização, o registro, os direitos e os deveres do estrangeiro no Brasil. Antes de iniciarmos a análise, apresentamos abaixo um resumo do Estatuto do Estrangeiro.

\section{Resumo da lei}

Em 19 de agosto de 1980, o último presidente militar brasileiro promulgou a lei $n^{\circ}$ 6.815, formada por 136 artigos que definem a situação do estrangeiro no Brasil. Essa lei, além de regularizar e organizar a vida do estrangeiro no Brasil, constrói ainda a imagem do estrangeiro que o país deseja aceitar ou manter em seu território.

O primeiro artigo diz que todo estrangeiro tem direito, em tempos de paz, de entrar e permanecer no Brasil e dele sair quando desejar. $O$ artigo $2^{\circ}$ se refere à aplicação da lei como forma de defesa de alguns valores nacionais, como segurança nacional, organização institucional, interesses políticos, socioeconômicos e culturais, além da defesa do trabalhador nacional. Além dos valores a serem defendidos, a lei também deixa claro que todas as concessões de visto são baseadas no interesse nacional, como mostra o $3^{\circ}$ artigo.

Os artigos $4^{\circ}$ ao 21 organizam os critérios de admissão, entrada e impedimento do estrangeiro. Dentre as questões mais pertinentes, esses artigos definem os tipos de visto de entrada, os requisitos para concessão ou para a negação do visto, os casos de dispensa da exigência do visto e os 
detalhes que caracterizam cada um deles. Veremos, com mais detalhes, esses artigos em nossa análise.

Do artigo 22 ao 25, se regulamenta a entrada de estrangeiros. Entre outras questões, esses artigos determinam que o estrangeiro só pode entrar no país onde houver fiscalização dos órgãos competentes dos Ministérios da Saúde, da Justiça e da Fazenda; atribuem ao transportador a responsabilidade de levar de volta o estrangeiro que tenha ficado por engano no país, assim como proíbe o estrangeiro de se afastar do local de entrada no país sem os documentos de viagem.

Já o impedimento da entrada do estrangeiro está definido nos artigos 26 e 27. O artigo 26 afirma que o visto de entrada é apenas uma expectativa de direito e, por isso, a entrada do estrangeiro pode ser proibida. $\mathrm{O}$ artigo 27 atribui à empresa transportadora a responsabilidade pela saída do estrangeiro que tenta entrar irregularmente no país.

Os artigos 28 e 29 respondem pela entrada do asilado político e seus direitos. A questão do registro do estrangeiro é tratada nos artigos 30 a 33 . Os artigos 34 e 35 tratam dos casos de prorrogação do prazo de estada. A mudança de visto e questões diretamente relacionadas a ela estão regulamentadas nos artigos 36 a 41 .

O artigo 42 prevê a possibilidade de alteração do nome do estrangeiro em alguns casos, como os que se seguem: quando for comprovado que está errado; se tiver sentido pejorativo ou expuser o seu titular ao ridículo; se sua pronúncia ou sua compreensão forem difíceis; e se puder ser traduzido ou adaptado à "prosódia da língua portuguesa". O artigo 43 atribui ao Ministério da Justiça a competência para autorizar a alteração de assentamentos no registro do estrangeiro.

A atualização do registro do estrangeiro no Brasil está prevista nos artigos 44 a 47 . O artigo 44 trata da atualização do registro de empresas nacionais com sócios estrangeiros. Além disso, Cartórios de Registro Civil devem remeter mensalmente cópias de registros de casamento e óbito de estrangeiros (artigo 45), assim como estabelecimentos hoteleiros e empresas mobiliárias devem informar ao Ministério da Justiça, quando solicitados, dados referentes aos estrangeiros que estão na condição de hóspedes ou locatários (artigo 46). O artigo 47 se refere à obrigação de registro para que estrangeiros 
passem a exercer suas atividades em entidades públicas ou privadas ou ainda para se matricular em estabelecimento de ensino (de qualquer grau).

O artigo 48 prevê as condições em que há o cancelamento ou o restabelecimento do registro de estrangeiro.

A saída e o retorno do estrangeiro ao país são legislados nos artigos 49 a 52. Em linhas gerais, esses artigos estabelecem as situações em que um estrangeiro pode entrar ou sair do país sem a necessidade de um novo visto, regulamento da existência do o laissez-passer ${ }^{90}$ e em quais condições o governo brasileiro pode conceder passaporte a um estrangeiro.

A deportação é tratada nos artigos 56 a 63. Casos de expulsão são tratados nos artigos 64 a 74. A extradição está regulamentada nos artigos 75 a 93. Os direitos e deveres do estrangeiro no Brasil são tratados nos artigos 94 a 109. A naturalização de estrangeiro está prevista nos artigos 110 a 123. Os artigos 124 e 125 tratam das infrações, das penalidades e suas execuções em relação ao estrangeiro. Todos esses artigos serão objeto de nossa análise.

Já o artigo 126 diz que a infração em que esteja prevista punição deve ser apurada em processo administrativo. O artigo 127 determina a utilização, em certos casos, do Código de Processo Penal, além do que está estabelecido no Estatuto do Imigrante em relação às punições nos casos de expulsão e extradição.

O artigo 128 cria o Conselho Nacional de Imigração, que está ligado ao Ministério do Trabalho, cuja responsabilidade se concentra na orientação, na coordenação e na fiscalização das atividades imigratórias. O artigo 129 determina que cabe ao Poder Executivo o estabelecimento de acordos internacionais sobre as condições de concessão, gratuidade, isenção ou dispensa dos vistos regulamentados por essa lei. A Tabela de Emolumentos Consulares e Taxas é criada pelo artigo 130, em cujo anexo está presente nessa lei (mas não será detalhada nesse resumo por se tratar de valores financeiramente datados). A criação da cédula de identidade para estrangeiro, portador de visto temporário ou permanente fica sob a guarda do Ministério da Justiça, conforme orientação do artigo 131. O artigo 132 autoriza o Poder

\footnotetext{
${ }^{90}$ Laissez-passer é o documento de viagem expedido ao estrangeiro que possui o passaporte de um país não reconhecido pelo governo brasileiro. Segundo a página da Polícia Federal, os países com os quais o Brasil não mantém relação diplomática são os seguintes: Reino do Butão, Ilhas Comores, República Centro Africana e Taiwan.
} 
Executivo a estabelecer acordos bilaterais com os países cujos cidadãos estejam em situação irregular no país. O artigo 133 trata dos processos em andamento durante a data de publicação da presente lei. Esse artigo afirma que esses processos são incluídos no que está previsto pela lei $941^{91}$ (de 13 de outubro de 1969) e seu regulamento (publicado na forma de decreto $66.689^{92}$, de 11 de junho de 1970).

O artigo 134 diz que o estrangeiro que estiver vivendo no país na condição prevista no artigo 26 da lei 941 (de 13 de outubro de $1969^{93}$ ) e quiser ficar no país deve solicitar sua permanência ao Ministério da Justiça em até noventa dias após a data de criação da presente lei. $O$ artigo 135 afirma que pode haver a regularização provisória dos estrangeiros mencionados no artigo anterior, ou seja, enquanto estiver sendo negociado o acordo, pode-se aceitar uma regularização por tempo pré-determinado. Por fim, o artigo 136 revoga uma série de outras leis que tratavam das mesmas questões abordadas pela lei 6.815 .

\section{Por uma tipologia dos estrangeiros}

O Estatuto do Estrangeiro trata da presença do estrangeiro em geral no país (e não apenas de um tipo específico de estrangeiro). Por isso, podemos ver quais são os estrangeiros discutidos nessa lei, realçar suas diferenças e as consequências jurídicas para cada um deles.

A primeira distinção feita em relação aos estrangeiros está diretamente relacionada ao tipo de visto que pode ser concedido a eles. Os tipos de visto para os estrangeiros entrarem no Brasil são os seguintes: trânsito, turista, temporário, permanente, de cortesia, oficial e diplomático ${ }^{94}$. Inicialmente, os quatro primeiros tipos de visto apresentam diferentes temporalidades que os

\footnotetext{
${ }^{91}$ A lei 941, de 13 de outubro de 1969, é o antigo Estatuto do Estrangeiro. Foi revogada pela lei 6.815.

92 O decreto 66.689, de 11 de junho de 1970, regulamenta a lei 941.

${ }^{93}$ Segue abaixo a citação do artigo referido:

“Art. 26. Aos nacionais dos países limítrofes, a autoridade encarregada da fiscalização poderá permitir a entrada e livre circulação nos municípios fronteiriços de seus respectivos territórios, bastando, para esse fim, a prova de identidade".

${ }^{94}$ Para este trabalho, deixaremos de lado três tipos de visto (cortesia, oficial e diplomático) por serem vistos concedidos em uma situação excepcional, ou seja, para funcionários das embaixadas/consulados e não para cidadãos comuns.
} 
diferenciam e, assim, os definem. Para nossa análise, citamos abaixo os artigos que tratam do prazo máximo de cada um dos vistos:

Art. $8^{\circ} \mathrm{O}$ visto de trânsito poderá ser concedido ao estrangeiro que, para atingir o país de destino, tenha de entrar em território nacional.

$\S 1^{\circ} \mathrm{O}$ visto de trânsito é válido para uma estada de até 10 (dez) dias improrrogáveis e uma só entrada.

$\S 2{ }^{\circ}$ Não se exigirá visto de trânsito ao estrangeiro em viagem contínua, que só se interrompa para as escalas obrigatórias do meio de transporte utilizado.

Art 12. O prazo de estada do turista será de até noventa dias.

Parágrafo único. O prazo poderá ser reduzido, em cada caso, a critério do Ministério da Justiça.

Art 14. O prazo de estada no Brasil, nos casos dos itens II e III do artigo 13 [visto temporário], será de até noventa dias, e, nos demais, salvo o disposto no parágrafo único deste artigo, o correspondente à duração da missão, do contrato, ou da prestação de serviços, comprovada perante a autoridade consular, observado o disposto na legislação trabalhista.

Art. 18. A concessão do visto permanente poderá ficar condicionada, por prazo não-superior a 5 (cinco) anos, ao exercício de atividade certa e à fixação em região determinada do território nacional.

O visto de trânsito serve apenas para que o estrangeiro possa passar pelo Brasil como uma escala para outro país (e, por isso, tem uma duração reduzida de 10 dias); o de turista, com prazo de até 3 meses, permite a entrada, mas não trabalho desse estrangeiro; o temporário, com o mesmo prazo do de turista, permite a realização do trabalho por parte do estrangeiro, mas por um prazo mais curto do que o visto permanente, que é o quarto tipo de visto concedido pelo governo e cuja duração é de 5 anos.

Há, assim, um visto de curta duração, dois de duração média e um de duração longa. Uma primeira representação dessas relações já é possível a partir do tempo de duração de cada visto, apesar de ainda ser insuficiente para a explicitação dos valores desse discurso ${ }^{95}$ :

\footnotetext{
${ }^{95}$ Baseamo-nos na oposição entre "permanente vs. temporário" proposta por Greimas e Landowski na já clássica análise sobre a lei de sociedades comerciais (Greimas, 1981: 90). Substituímos apenas o termo "temporário" pelo "transitório" para não coincidir o conceito com o nome do visto temporário.
} 
Tempo: permanente

Visto permanente

Tempo: transitório

Visto de trânsito

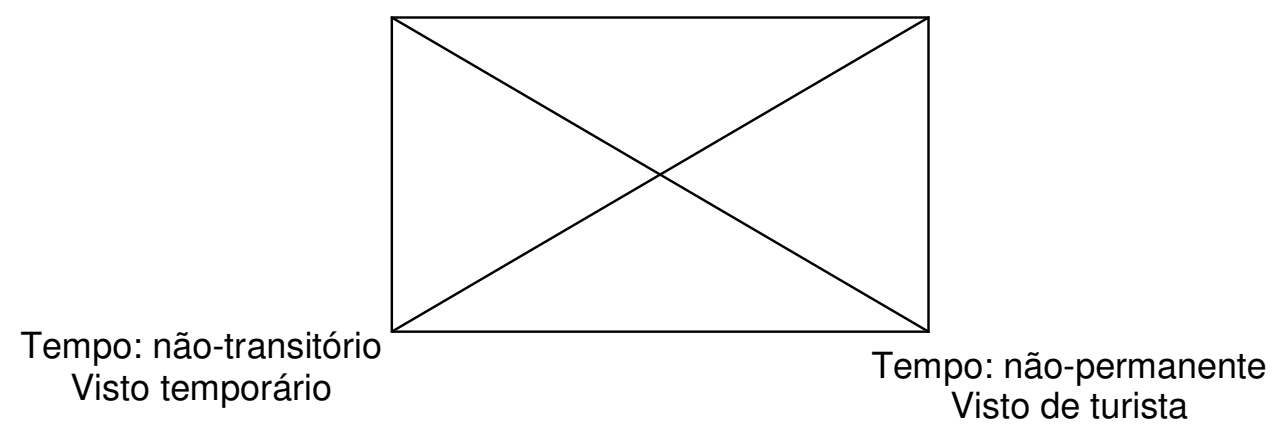

Vimos, nessa rápida descrição, que o tempo de duração da estada do estrangeiro em solo nacional produz uma primeira diferença entre os vistos. Contudo, há ainda outra distinção relativa à permissão ou à proibição de se trabalhar no Brasil. Assim, além do tempo, o /poder-fazer/ é uma característica determinante para a distinção dos vistos. Para nos certificarmos de que se trata de diferentes /fazeres/, precisamos ainda analisar outros artigos da mesma lei. Apresentamos abaixo os três artigos que definem o /fazer/ dos vistos de turista, temporário e permanente.

Art. 9 $\mathrm{O}$ visto de turista poderá ser concedido ao estrangeiro que venha ao Brasil em caráter recreativo ou de visita, assim considerado aquele que não tenha finalidade imigratória, nem intuito de exercício de atividade remunerada.

Art. 13. O visto temporário poderá ser concedido ao estrangeiro que pretenda vir ao Brasil:

I - em viagem cultural ou em missão de estudos;

II - em viagem de negócios;

III - na condição de artista ou desportista;

IV - na condição de estudante;

V - na condição de cientista, professor, técnico ou profissional de outra categoria, sob regime de contrato ou a

serviço do Governo brasileiro;

VI - na condição de correspondente de jornal, revista, rádio, televisão ou agência noticiosa estrangeira.

Art. 16. O visto permanente poderá ser concedido ao estrangeiro que pretenda se fixar definitivamente no Brasil.

O visto de trânsito, não citado acima, se refere ao estrangeiro que está de passagem, ou seja, um visto regido pelo tempo mais curto em que se pode 
permanecer no Brasil (10 dias), porque ele simplesmente não fará nada no país. O visto de turista é concedido ao sujeito que vem ao país para descansar, se divertir e não para trabalhar e se fixar. O visto temporário tem uma curta duração para permitir o trabalho de um estrangeiro que não vai se estabelecer definitivamente no país e geralmente está a trabalho de um empresa estrangeira. Já o visto permanente está associado ao imigrante, ou seja, aquele que chega ao país para trabalhar e se fixar no país. Por essa razão, seu visto tem um prazo de duração maior (5 anos).

O visto temporário apresenta alguns detalhes a mais em relação aos outros vistos por especificar as atividades que se enquadram nesse tipo de visto. Assim, no caso do visto temporário, o /fazer/ é restrito a determinadas profissões, como as seguintes:

\footnotetext{
Art. 13. O visto temporário poderá ser concedido ao estrangeiro que pretenda vir ao Brasil:

I - em viagem cultural ou em missão de estudos;

II - em viagem de negócios;

III - na condição de artista ou desportista;

IV - na condição de estudante;

V - na condição de cientista, professor, técnico ou profissional de outra categoria, sob regime de contrato ou a serviço do Governo brasileiro;

$\mathrm{VI}$ - na condição de correspondente de jornal, revista, rádio, televisão ou agência noticiosa estrangeira.
}

Temas como cultura, pesquisa, estudo, negócios, jornalismo, entre outros, são característicos desse visto. O visto temporário para essas atividades contempla profissionais estrangeiros que chegam ao país para realizar uma determinada atividade que, em grande parte, está diretamente relacionada a eles próprios (como pesquisadores, estudantes, artistas e esportistas) e ao seu país de origem (correspondente, empresários etc.). Em outras palavras, ao contrário do imigrante, como veremos abaixo, as atividades associadas ao visto temporário dizem respeito, em certa medida, a um /fazer/ que não está incluído nas narrativas da sociedade brasileira, mas sim na dos países de origem desse estrangeiro.

Já o visto permanente serve, como o próprio nome diz, para o estrangeiro que pretenda se estabelecer por um longo tempo ou definitivamente no Brasil. Para esse tipo de estrangeiro, a lei apresenta 
claramente as qualidades desejadas para a concessão do visto permanente (parágrafo único do artigo 16, já citado):

Parágrafo único. A imigração objetivará, primordialmente, propiciar mão-deobra especializada aos vários setores da economia nacional, visando ao aumento da produtividade, à assimilação de tecnologia e à captação de recursos para setores específicos.

Em outras palavras, a lei explicita que o seu interesse é por mão-deobra especializada, em que se possa, a partir do trabalho desse imigrante (cujo papel temático pode ser entendido como o do "especialista"), aumentar os índices de produtividade, assim como o desenvolvimento tecnológico de determinados setores nacionais. Dessa forma, relacionando a representação do quadrado semiótico da temporalidade dos vistos, podemos acrescentar os diferentes /fazeres/ permitidos:

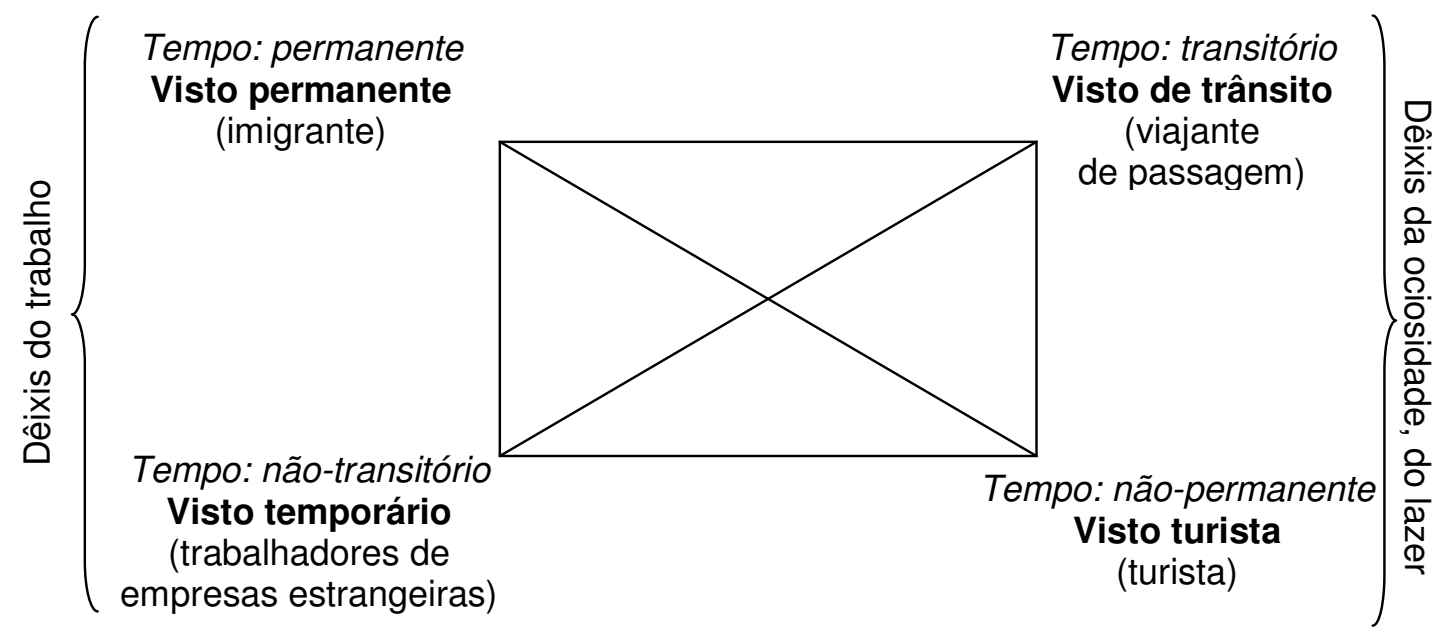

Cada termo do quadrado acima vai produzir um determinado tipo de papel temático para cada temporalidade: o do imigrante (tempo permanente), o do estrangeiro empregado de empresa estrangeira (tempo não-transitório), o do turista (tempo não-permanente) e o do estrangeiro que está de passagem (tempo transitório). O visto de trânsito não apresenta nenhum /fazer/, pois o estrangeiro fica por pouco tempo no país. O visto de turista é concedido somente quando o estrangeiro entra em "caráter recreativo ou de visita" e que não tenha "finalidade imigratória, nem intuito de exercício de atividade remunerada". Em outras palavras, o turista não pode exercer certos /fazeres/ 
(como o trabalho), mas pode apresentar outro /fazer/, relacionado à ideia do descanso, do relaxamento e da diversão. No caso do visto permanente, quase todos os /fazeres/ são permitidos. Os /fazeres/ interditados serão descritos abaixo, pois fazem parte de outra seção da lei. Por fim, o visto temporário permite o /fazer/ voltado para o trabalho em determinadas áreas (como vimos no artigo 13, citado acima).

O modo como a lei organiza os diferentes tempos de permanência no país e seus /fazeres/ permitidos (ou não) mostra que o interesse do país está circunscrito a um determinado tipo de /fazer/ do estrangeiro que veio para se fixar: aquele que pode, com seu /saber-fazer/ e com o seu próprio /fazer/, contribuir para o desenvolvimento econômico e tecnológico de determinados setores produtivos nacionais. Em outras palavras, o país apenas concede visto permanente (que, na realidade, é apenas de tempo mais longo) aos imigrantes que mostrem formação educacional distinta e que interessem ao país.

Vemos, assim, como o discurso é orientado, no caso da seleção do imigrante, para valores voltados ao desenvolvimento do capital e do fazer econômico, em oposição aos valores do lazer e do descanso, característicos do visto de turista.

É a partir desse quadrado ${ }^{96}$ que poderemos observar como o discurso orienta os casos de registro, punições, deveres e direitos de cada estrangeiro, começando pela obrigatoriedade do registro.

\section{Sobre o registro do estrangeiro}

O registro do estrangeiro é similar ao registro geral existente para o cidadão brasileiro. A exigência de registro se aplica aos estrangeiros que entram com visto permanente ou provisório, isto é, aos estrangeiros que entram no país para exercer alguma atividade profissional.

\footnotetext{
${ }^{96} \mathrm{O}$ Estatuto do Estrangeiro trata também de outra figura do estrangeiro: o asilado. Como a referida lei trata dessa figura em apenas dois artigos, vamos mencioná-la rapidamente em uma nota de rodapé. Segundo o artigo 28 menciona que o estrangeiro que entrar no país na condição de asilado fica sujeito aos deveres impostos pelo Direito Internacional, pela legislação nacional vigente e pelo Estado brasileiro. Além disso, o artigo 29 afirma que o asilado não pode sair do país sem prévia autorização do Governo Federal. Se o fizer, a saída será considerada uma renúncia à sua condição de asilado, que não poderá ser restituída nos casos de retorno ao Brasil.
} 
Art 30. O estrangeiro admitido na condição de permanente, de temporário (art. 13, itens I, e de IV a VI), ou de asilado, é obrigado a registrar-se no Ministério da Justiça, dentro dos trinta dias seguintes à entrada ou à concessão do asilo e a identificar-se pelo sistema datiloscópico, observadas as disposições regulamentares.

É por meio do registro que uma série de ações se abre ao estrangeiro: trabalhar, alugar uma moradia, ingressar em uma instituição de ensino. Em outras palavras, o registro é o /poder-fazer/ do estrangeiro que veio trabalhar no país, ou seja, é a autorização para ele realizar certas ações. Em certa medida, o registro é a forma encontrada para se dar a autorização do /fazer/ ao estrangeiro e, ao mesmo tempo, controlá-lo e fiscalizá-lo em suas atividades no país. Uma prova de que existe um controle sobre a atividade do estrangeiro no país está explicitada nos artigos abaixo:

Art. 44. A Junta Comercial, ao registrar firma de que participe estrangeiro, remeterá ao Ministério da Justiça os dados de identificação do estrangeiro e os do seu documento de identidade emitido no Brasil.

Parágrafo único. Tratando-se de sociedade anônima, a providência é obrigatória em relação ao estrangeiro que figure na condição de administrador, gerente, diretor ou acionista controlador.

Art. 45. Os Cartórios de Registro Civil remeterão, mensalmente, ao Ministério da Justiça cópia dos registros de casamento e de óbito de estrangeiro.

Art 46. O estabelecimento hoteleiro, a empresa imobiliária, o proprietário, locador, sublocador ou locatário de imóvel e o síndico de edifício remeterão ao Ministério da Justiça os dados de identificação do estrangeiro admitido na condição de hóspede, locatário, sublocatário ou morador.

O Ministério da Justiça tem o papel de centralizador das informações sobre os estrangeiros. Tanto que a lei afirma que instâncias como a Junta Comercial, Cartórios de Registro Civil e estabelecimentos hoteleiros ou empresas imobiliárias devem repassar ao Ministério da Justiça todas as informações a respeito do estrangeiro, seja na forma de uma obrigação, seja quando forem solicitadas a eles essas informações.

Assim como outros documentos relacionados à presença do estrangeiro no país, o registro também pode ser cancelado, como nos mostra o artigo 49:

Art. 49. O estrangeiro terá o registro cancelado:

I - se obtiver naturalização brasileira;

II - se tiver decretada sua expulsão;

III - se requerer a saída do território nacional em caráter definitivo, renunciando, expressamente, ao direito de retorno previsto no artigo 51; 
IV - se permanecer ausente do Brasil por prazo superior ao previsto no artigo 51 ;

$\mathrm{V}$ - se ocorrer a transformação de visto de que trata o artigo 42;

$\mathrm{VI}$ - se houver transgressão do artigo 18, artigo 37 , § 2ำ, ou 99 a 101; e

VII - se temporário ou asilado, no término do prazo de sua estada no território nacional.

O estrangeiro perde seu registro se houver uma transformação em seu /ser/. É o caso de quando ele se naturaliza ou quando seu visto muda para diplomático. Ele pode também perder seu registro quando há uma mudança espacial e temporal: sair do país oficialmente, ficar fora do país por mais de dois anos ou quando terminar o prazo de seu visto.

Em certos casos, a perda do registro pode ser considerada uma punição na medida em que ela desautoriza o estrangeiro a trabalhar no Brasil. Assim, ao transformar sua condição ou exceder prazos determinados pela lei, o estrangeiro acaba por perder sua autorização de trabalho no Brasil.

O Estatuto do Estrangeiro ainda permite, ao estrangeiro, adaptar o nome que constará em seu registro:

\footnotetext{
Art. 42. O nome do estrangeiro, constante do registro (art. 30), poderá ser alterado:

I - se estiver comprovadamente errado;

II - se tiver sentido pejorativo ou expuser o titular ao ridículo; ou

III - se for de pronunciação e compreensão difíceis e puder ser traduzido ou adaptado à prosódia da língua portuguesa.

$\S 1^{\circ} \mathrm{O}$ pedido de alteração de nome deverá ser instruído com a documentação prevista em Regulamento e será sempre objeto de investigação sobre o comportamento do requerente.

$\S 2^{\circ}$ Os erros materiais no registro serão corrigidos de ofício.

$\S 3^{\circ} \mathrm{A}$ alteração decorrente de desquite ou divórcio obtido em país estrangeiro dependerá de homologação, no Brasil, da sentença respectiva.

$\S 4^{\circ}$ Poderá ser averbado no registro o nome abreviado usado pelo estrangeiro como firma comercial registrada ou em qualquer atividade profissional.
}

Vemos acima que há algumas preocupações quanto à identificação do estrangeiro em seu registro. A primeira, sobre a correção de seu nome: como em qualquer documento, deve constar a grafia correta. A segunda, se tiver um sentido pejorativo ou expor o estrangeiro ao ridículo. Nesse caso, o sentido pejorativo e a possibilidade de se ridicularizar o estrangeiro se referem a uma sinonímia imprevista entre o nome próprio ou sobrenome do estrangeiro e denominações da língua portuguesa. A lei permite, assim, evitar essa situação para não constranger o estrangeiro. A terceira, se existir uma dificuldade de 
pronúncia ou de compreensão (obviamente, para um brasileiro), o nome pode ser alterado quando houver a possibilidade de ser traduzido ou adaptado à prosódia da língua portuguesa. Isso facilita a identificação do estrangeiro e evita o estranhamento por parte de algum brasileiro.

A fiscalização realizada pelo Ministério da Justiça não pode ser considerada uma punição, apenas um controle. Para os casos de punição, a lei explicita quais são as infrações e suas formas de punição, como veremos abaixo.

\section{Sobre interdições e punições}

Além dos direitos e deveres (que serão analisados na próxima seção), o Estatuto do Estrangeiro prevê também as punições às infrações cometidas pelos estrangeiros, assim como os casos em que elas não podem ser aplicadas. Assim, veremos, nesta seção, como se organizam discursivamente as interdições, as proibições e as punições relativas à presença do estrangeiro no Brasil.

Para começar, é necessário pensar que os direitos, os deveres e as interdições fazem parte de um contrato (social e virtual) estabelecido entre o Estado brasileiro e os estrangeiros. Dessa forma, o estrangeiro, na qualidade de um actante-sujeito, sabe de início aquilo que ele pode e não pode fazer (direitos), assim como o que ele deve ou não deve fazer (deveres). Caso esse contrato seja rompido por um fazer não permitido ou não previsto nesse contrato (ou ainda por não fazer o que se deve), ele receberá a sanção do Estado na forma de punição, que está também prevista nesse discurso.

Em relação à interdição, temos no artigo 7 quais sujeitos não podem receber o visto de entrada, caso ele seja solicitado. Os itens abaixo relacionados configuram modalmente os sujeitos desprovidos de competência mínima para entrar em um determinado percurso narrativo (o da autorização para entrar no país), como podemos ver abaixo:

Art. $7^{\circ}$ Não se concederá visto ao estrangeiro:

I - menor de 18 (dezoito) anos, desacompanhado do responsável legal ou sem a sua autorização expressa;

II - considerado nocivo à ordem pública ou aos interesses nacionais;

III - anteriormente expulso do País, salvo se a expulsão tiver sido revogada; 
IV - condenado ou processado em outro país por crime doloso, passível de extradição segundo a lei brasileira; ou

V - que não satisfaça às condições de saúde estabelecidas pelo Ministério da Saúde.

Para se justificar a negação do pedido de visto de entrada, os elementos apresentados são os seguintes: o de /não-poder-ser/ (no caso do menor de idade) $^{97}$, o de /ser-malevolente/ e /fazer-malevolente/ (considerado uma ameaça), o de já estar em disjunção com o Estado brasileiro (expulsão), o sancionado negativamente em outro país e o do /não-poder-fazer/ (no caso da saúde). Os itens II a $\mathrm{V}$ possuem uma relação em comum: a ideia da defesa nacional, na medida em que um estrangeiro não pode entrar no país se for observado qualquer tipo de ameaça à nação brasileira (seja porque o estrangeiro já foi de alguma forma condenado, no país ou fora dele, seja porque ele pode ser considerado perigoso para a ordem pública ou para a saúde coletiva).

Além dessa interdição, a lei trata também das punições que levam o estrangeiro a ser obrigado a sair do país. Em relação às punições, veremos como se configuram narrativa e discursivamente a deportação, a expulsão e a extradição. Nossa análise ressaltará ainda as diferenças e as semelhanças entre as punições previstas pela lei.

A deportação pode ocorrer se houver a entrada ou a estada irregular do estrangeiro. Assim, todo o estrangeiro que, por exemplo, ultrapassar o prazo máximo de permanência prevista em seu visto está sujeito à deportação. Em outras palavras, ele deixou de cumprir o contrato anteriormente estabelecido ao permanecer no país por mais tempo do que determinado pelo visto. Por isso, ele passa de um /ser/ a um /não-ser/ e é sancionado negativamente com a exclusão do país.

Art. 56. Nos casos de entrada ou estada irregular de estrangeiro, se este não se retirar voluntariamente do território nacional no prazo fixado em Regulamento, será promovida sua deportação.

$\S 1^{\circ}$ Será igualmente deportado o estrangeiro que infringir o disposto nos artigos $21, \S 2^{\circ}, 24,37, \S 2^{\circ}$, 98 a 101, $\S 1^{\circ}$ o ou $2^{\circ}$ do artigo 104 ou artigo 105.

$\S 2^{\circ}$ Desde que conveniente aos interesses nacionais, a deportação far-se-á independentemente da fixação do prazo de que trata o caput deste artigo.

\footnotetext{
${ }^{97}$ A menoridade é um dos traços que define um sujeito como incapacitado civil, como vimos na primeira análise deste capítulo. O Código Civil de 1916 era ainda o vigente naquele período.
} 
Art. 57. A deportação consistirá na saída compulsória do estrangeiro.

Parágrafo único. A deportação far-se-á para o país da nacionalidade ou de procedência do estrangeiro, ou para outro que consinta em recebê-lo.

A deportação se aplica ainda aos casos em que o sujeito exerce alguma atividade profissional (logo, um /fazer/) quando o seu visto não permite, caracterizando-se igualmente como um sujeito irregular.

O estrangeiro deportado só pode voltar ao Brasil, segundo essa lei, se ele pagar todas as despesas que o governo brasileiro teve no momento da deportação, assim como eventuais multas indicadas no processo. Existe, assim, a possibilidade de o deportado um dia voltar ao Brasil, se desejar. Em certa medida, se essa possibilidade de retorno não se configura como uma recompensa ao deportado, há ao menos uma condescendência do Estado brasileiro:

Art. 63. O deportado só poderá reingressar no território nacional se ressarcir o Tesouro Nacional, com correção monetária, das despesas com a sua deportação e efetuar, se for o caso, o pagamento da multa devida à época, também corrigida.

A deportação não produz uma exclusão definitiva e irreversível. Em outras palavras, o punido com a deportação não vai, necessariamente, viver essa condenação para sempre, uma característica que diferencia a deportação da expulsão, que é outra forma de exclusão do país. No caso da expulsão, o foco está centrado no fato de o estrangeiro se configurar em um perigo para país, conforme trecho abaixo:

Art. 64. É passível de expulsão o estrangeiro que, de qualquer forma, atentar contra a segurança nacional, a ordem política ou social, a tranquilidade ou moralidade pública e a economia popular, ou cujo procedimento o torne nocivo à conveniência e aos interesses nacionais.

Parágrafo único. É passível, também, de expulsão o estrangeiro que:

a) praticar fraude a fim de obter a sua entrada ou permanência no Brasil;

b) havendo entrado no território nacional com infração à lei, dele não se retirar no prazo que lhe for determinado para fazê-lo, não sendo aconselhável a deportação;

c) entregar-se à vadiagem ou à mendicância; ou

d) desrespeitar proibição especialmente prevista em lei para estrangeiro.

Se a deportação é uma punição ligada ao /ser/ e ao /fazer/ do estrangeiro, a expulsão decorre de uma sanção principalmente sobre o /fazermalevolente/ do estrangeiro, que rompe também um contrato com o Estado 
brasileiro. Esse /fazer/ é, então, sancionado como uma ameaça ao Estado brasileiro. Nesse caso, diversos são os temas nesse artigo: a da segurança, da ordem, da moralidade, da economia e dos interesses nacionais.

Todos os temas no artigo 65 têm uma ideia em comum: a de um efeito de homogeneidade que caracterizaria a sociedade e o Estado brasileiros. Essa homogeneidade, por conseguinte, não pode ser abalada ou ameaçada pelo estrangeiro em hipótese alguma, como vemos em um dos primeiros artigos dessa lei:

Art. 2ำ $\mathrm{Na}$ aplicação desta Lei atender-se-á precipuamente à segurança nacional, à organização institucional, aos interesses políticos, sócioeconômicos e culturais do Brasil, bem assim à defesa do trabalhador nacional.

Dessa forma, se o estrangeiro é sancionado como o sujeito de um /fazer-malevolente/ contra o Brasil, ele é punido com a expulsão do país. Nesse caso, ele é considerado "mau caráter" (em oposição ao "bom brasileiro") e sua punição é a saída do país. Já o parágrafo único do artigo 64 se refere à prática ilegal para entrada no país ou mesmo à prática estigmatizada da mendicância. Mesmo não se tratando de um /fazer-malevolente/ propriamente dito, a prática ilegal e a mendicância têm, em alguma medida, um fazer juridicamente interditado, para o primeiro caso, e um fazer socialmente condenado, para o segundo.

Há algumas diferenças entre deportação e expulsão. Enquanto a deportação é motivada, principalmente, por uma infração "burocrática" (fim do prazo de validade do visto ou exercer trabalho quando o visto não permite), a expulsão envolve uma punição relacionada, na maior parte das descrições da lei, à ameaça (social, política e de saúde) à nação brasileira. Além disso, segundo Mello, quando um estrangeiro é expulso do país, ele não pode mais retornar, enquanto a deportação é, como vimos, reversível (2002: 1008).

A extradição ${ }^{98}$ ocorre quando há uma solicitação de outro país. Essa solicitação decorre de um /fazer-malevolente/ (ou contra as leis) do sujeito implicado no pedido de extradição. Em outras palavras, o sujeito foco do

\footnotetext{
98 Recentemente, a extradição se tornou manchete nos meios de comunicação com o julgamento (da justiça e da mídia) de Cesare Battisti, militante de um grupo político na década de 1970 que combatia o governo italiano. O julgamento de Battisti foi marcado pela peculiaridade de o Supremo Tribunal Federal deixar a decisão de extradição para o Presidente da República.
} 
pedido de extradição cometeu algum crime em outro percurso narrativo não associado ao seu percurso no espaço brasileiro.

Art. 75. A extradição poderá ser concedida quando o governo requerente se fundamentar em convenção, tratado ou quando prometer ao Brasil a reciprocidade.

O processo de extradição envolve a presença de dois destinadores distintos por trás de todas as etapas que culminam na decisão de extraditar ou não o estrangeiro. A primeira etapa da extradição ocorre preferencialmente por meio da via diplomática ou diretamente entre os Estados e, assim, o Estado brasileiro recebe o pedido de extradição junto com as provas que embasam tal pedido. Essas provas, de um modo geral, se referem à decisão do juiz do país requerente, onde ocorreu a produção da sanção negativa desse estrangeiro. Após a análise do pedido pelo Ministério da Justiça brasileiro, o pedido é julgado pelo Superior Tribunal Federal.

Antes de se encerrar o processo de extradição, o Estatuto do Estrangeiro determina que o país requerente deve comprometer-se com 0 Brasil e com o próprio extraditando. São esses os critérios a serem cumpridos pelo país requerente, segundo a lei:

\footnotetext{
Art. 90. Não será efetivada a entrega sem que o Estado requerente assuma o compromisso:

I - de não ser o extraditando preso nem processado por fatos anteriores ao pedido;

II - de computar o tempo de prisão que, no Brasil, foi imposta por força da extradição;

III - de comutar em pena privativa de liberdade a pena corporal ou de morte, ressalvados, quanto à última, os casos em que a lei brasileira permitir a sua aplicação;

IV - de não ser o extraditando entregue, sem consentimento do Brasil, a outro Estado que o reclame; e

V - de não considerar qualquer motivo político, para agravar a pena.
}

Semioticamente, o Estado estrangeiro requerente surge como um destinador-manipulador ao solicitar a extradição do estrangeiro, baseado em uma sanção anterior de um /fazer-malevolente/ do extraditando em solo estrangeiro. O governo brasileiro ocupa o espaço do destinatário-sujeito ao aceitar o pedido de extradição, mas logo passa a ocupar, em diferentes atores burocráticos, o papel de destinador-julgador que analisa a validade do pedido e 
a veracidade dos documentos apresentados. Por fim, no momento da extradição, o governo brasileiro passa a ser o destinador-manipulador, ao exigir, como condição para a extradição, que o Estado estrangeiro requerente cumpra certos princípios que não prejudiquem o extraditando, que deve apenas cumprir a pena já estabelecida pela sanção que motivou o pedido de extradição.

Uma última observação deve ser feita: ao contrário da deportação e da expulsão, que apresentam apenas um percurso narrativo realizado no próprio espaço brasileiro, no qual o estrangeiro é ou faz algo que não poderia, a extradição apresenta, além do percurso narrativo no Brasil, um percurso narrativo anterior em outro país. É a partir desse outro percurso que o pedido de extradição é feito e analisado. Caso esse percurso narrativo anterior "estrangeiro" esteja em conformidade com os artigos previstos no Estatuto do Estrangeiro, a extradição do estrangeiro é aceita pela justiça brasileira e, posteriormente, realizada.

Em todas as formas de punição analisadas, o que há em comum é que elas promovem uma completa disjunção do estrangeiro em relação ao Brasil. Em outras palavras, essas punições visam à completa exclusão da presença do estrangeiro em relação ao país, devido a diferentes causas e motivos. Esquematicamente, temos o seguinte quadro comparativo:

\begin{tabular}{|c|c|c|c|}
\hline $\begin{array}{c}\text { Operação sobre } \\
\text { o contrato } \\
\text { (Estado e } \\
\text { estrangeiro) }\end{array}$ & Deportação & Expulsão & Extradição \\
\hline Motivação & Ruptura de & \multicolumn{3}{|c|}{ Exclusão } \\
& $\begin{array}{c}\text { Ruptura de } \\
\text { contrato no } \\
\text { espaço jurídico } \\
\text { brasileiro }\end{array}$ & $\begin{array}{c}\text { contrato no } \\
\text { espaço social e } \\
\text { jurídico brasileiro }\end{array}$ & $\begin{array}{c}\text { Ruptura de } \\
\text { contrato no } \\
\text { espaço jurídico e } \\
\text { social estrangeiro }\end{array}$ \\
\hline
\end{tabular}




\begin{tabular}{|c|c|c|c|}
\hline $\begin{array}{l}\text { Organização } \\
\text { sintáxica } \\
\text { (percurso } \\
\text { narrativo) }\end{array}$ & $\begin{array}{c}\text { Situação irregular } \\
\text { (/ser/ } \rightarrow \text { /não-ser/) } \\
\text { Ações irregulares } \\
\text { (/dever-fazer/ } \rightarrow \\
\text { /não-fazer/) } \\
\text { (/não-poder-fazer/ } \\
\rightarrow \text { /fazer/) }\end{array}$ & $\begin{array}{c}\text { Fazer } \\
\text { malevolente } \\
\text { (ameaça) }\end{array}$ & $\begin{array}{c}P N \text { decorrente do } \\
\text { pedido de outro } \\
\text { Estado } \\
\text { (programa } \\
\text { narrativo prévio } \\
\text { de outro Estado } \\
\text { nacional) }\end{array}$ \\
\hline
\end{tabular}

Ao mesmo tempo em que instaura os regimes de punição ao estrangeiro, a presente lei coloca os casos em que essas punições não podem ser aplicadas. Em certa medida, há um conflito narrativo no centro das punições: por um lado, o estrangeiro apresenta o /fazer/ e o /ser/ necessários para a aplicação da punição; por outro, ele pode apresentar situações ou características que impeçam a aplicação da punição.

No caso da deportação e da expulsão, a lei diz: "Art. 63. Não se procederá à deportação se implicar em extradição inadmitida pela lei brasileira" e "Art. 74. Não se procederá à expulsão se implicar em extradição inadmitida pela lei brasileira". Um estrangeiro não pode, portanto, ser deportado ou expulso nos casos previstos no artigo 76, que relata as situações nas quais não se pode extraditar um estrangeiro. O cancelamento da extradição apresenta um número maior de possibilidades, talvez porque envolva a presença de outro Estado nacional:

Art. 76. Não se concederá a extradição quando:

I - se tratar de brasileiro, salvo se a aquisição dessa nacionalidade verificar-se após o fato que motivar o pedido;

II - o fato que motivar o pedido não for considerado crime no Brasil ou no Estado requerente;

III - o Brasil for competente, segundo suas leis, para julgar o crime imputado ao extraditando;

IV - a lei brasileira impuser ao crime a pena de prisão igual ou inferior a 1 (um) ano;

V - o extraditando estiver a responder a processo ou já houver sido condenado ou absolvido no Brasil pelo mesmo fato em que se fundar o pedido;

VI - estiver extinta a punibilidade pela prescrição segundo a lei brasileira ou a do Estado requerente;

VII - o fato constituir crime político; e

VIII - o extraditando houver de responder, no Estado requerente, perante Tribunal ou Juízo de exceção. 
$\S 1^{\circ} \mathrm{A}$ exceção do item VII não impedirá a extradição quando o fato constituir, principalmente, infração da lei penal comum, ou quando o crime comum, conexo ao delito político, constituir o fato principal.

$\S 2^{\circ}$ Caberá, exclusivamente, ao Supremo Tribunal Federal, a apreciação do caráter da infração.

$\S 3^{\circ} \mathrm{O}$ Supremo Tribunal Federal poderá deixar de considerar crimes políticos os atentados contra Chefes de Estado ou quaisquer autoridades, bem assim os atos de anarquismo, terrorismo, sabotagem, seqüestro de pessoa, ou que importem propaganda de guerra ou de processos violentos para subverter a ordem política ou social.

Como vimos acima, o pedido de extradição envolve dois destinadores de percursos narrativos distintos. Isso ocorre porque o sujeito alvo do pedido de extradição cometeu alguma falta em outro programa narrativo, quando estava submetido a um destinador que não era o Estado brasileiro. Por conta dessa configuração narrativa, o pedido de extradição não pode ser realizado quando se tratar de um cidadão brasileiro nato. Essa é também a razão de a lei deixar claro que, se esse brasileiro tiver adquirido a nacionalidade do país que está solicitando a extradição, ela pode ser realizada.

Além disso, prevalece nesse artigo o tema da soberania nacional brasileira. Por isso, atos considerados como crimes em outros países, mas não no Brasil, não podem ser usados como motivação para o pedido de extradição. O mesmo ocorre nos casos em que o Brasil pode julgar o extraditando, quando o ato cometido por ele já tiver prescrito ou se o pedido de extradição for motivado por crime político.

Vimos, nesta análise, quais os critérios estabelecidos para se negar o visto de entrada a um estrangeiro. Além disso, vimos também as diferentes punições (deportação, expulsão e extradição), assim como os critérios para anulá-las. Além das punições, o Estatuto do estrangeiro apresenta também os direitos e os deveres do estrangeiro no país. São essas questões que analisaremos a seguir.

\section{Sobre os direitos e deveres do estrangeiro no Brasil}

Segundo o Estatuto do Estrangeiro, todos os estrangeiros residentes no Brasil possuem os mesmos direitos ${ }^{99}$ que os brasileiros, sendo apenas

\footnotetext{
${ }^{99}$ Citamos o referido artigo que trata dos direitos do estrangeiro: "Art. 95. O estrangeiro residente no Brasil goza de todos os direitos reconhecidos aos brasileiros, nos termos da Constituição e das leis".
} 
ressaltadas as restrições previstas na Constituição. Em outras palavras, o percurso narrativo no qual está o estrangeiro é o mesmo em que estão os brasileiros. No entanto, uma prescrição presente na seção "Dos direitos e deveres do estrangeiro" está relacionada ao direito de ir e vir. No caso do estrangeiro que tem um visto permanente ou temporário (em determinadas profissões), toda vez que ele mudar de residência, será obrigado a comunicar ao Ministério da Justiça sua mudança de endereço. Em alguns casos, o estrangeiro é até mesmo proibido de se mudar, como podemos observar em um dos dois artigos abaixo:

Art. 100. O estrangeiro admitido na forma do artigo 18 , ou do artigo $37, \S 2^{\circ}$, para o desempenho de atividade profissional certa, e a fixação em região determinada, não poderá, dentro do prazo que Ihe for fixado na oportunidade da concessão ou da transformação do visto, mudar de domicílio nem de atividade profissional, ou exercê-la fora daquela região, salvo em caso excepcional, mediante autorização prévia do Ministério da Justiça, ouvido o Ministério do Trabalho, quando necessário.

Art. 101. O estrangeiro registrado é obrigado a comunicar ao Ministério da Justiça a mudança do seu domicílio ou residência, devendo fazê-lo nos 30 (trinta) dias imediatamente seguintes à sua efetivação

Dessa forma, por meio da lei, existem certas limitações ao /fazer/ do sujeito-estrangeiro no Brasil. Se ele entra no país para exercer determinada profissão, ele não está autorizado a mudá-la, a não ser que haja aprovação dos Ministérios do Trabalho e da Justiça. Além disso, o que seria um simples fazer orientado por uma programação (mudar de residência) precisa, no caso do estrangeiro, ser precedido por um /fazer informacional/ ao destinador, ou seja, ele deve comunicar seus movimentos a uma instância superior, quando for o caso. Dessa maneira, o Estado brasileiro pode continuar a controlar e a fiscalizar a presença do estrangeiro no país. A questão da comunicação dessa informação, seja ao Ministério do Trabalho seja ao Ministério da Justiça, é uma questão de /dever/, ou seja, o estrangeiro é obrigado por lei a realizar tal comunicação.

Além disso, todo e qualquer estrangeiro que esteja em solo brasileiro, não pode realizar determinadas atividades, conforme vemos no artigo abaixo citado:

Art. 105. É vedado ao estrangeiro: 
I - ser proprietário, armador ou comandante de navio nacional, inclusive nos serviços de navegação fluvial e lacustre;

II - ser proprietário de empresa jornalística de qualquer espécie, e de empresas de televisão e de radiodifusão, sócio ou acionista de sociedade proprietária dessas empresas;

III - ser responsável, orientador intelectual ou administrativo das empresas mencionadas no item anterior;

IV - obter concessão ou autorização para a pesquisa, prospecção, exploração e aproveitamento das jazidas, minas e demais recursos minerais e dos potenciais de energia hidráulica;

V - ser proprietário ou explorador de aeronave brasileira, ressalvado o disposto na legislação específica;

VI - ser corretor de navios, de fundos públicos, leiloeiro e despachante aduaneiro;

VII - participar da administração ou representação de sindicato ou associação profissional, bem como de entidade fiscalizadora do exercício de profissão regulamentada;

VIII - ser prático de barras, portos, rios, lagos e canais;

IX - possuir, manter ou operar, mesmo como amador, aparelho de radiodifusão, de radiotelegrafia e similar, salvo reciprocidade de tratamento; e

$X$ - prestar assistência religiosa às Forças Armadas e auxiliares, e também aos estabelecimentos de internação coletiva.

Do artigo 105, podemos depreender que há uma preocupação com a defesa nacional, uma vez que o estrangeiro não pode ser proprietário, e consequentemente, controlar elementos considerados imprescindíveis para o patrimônio nacional (como os recursos naturais: minérios e energia hidrelétrica), assim como o espaço aéreo, os meios de comunicação (como rádio controle, jornais, rádios e canais de televisão) e as forças armadas. Assim, um estrangeiro não pode ser proprietário de empresas consideradas estratégias para o país (como minérios e energia elétrica) ou de áreas em que o estrangeiro pode ser considerado uma ameaça ao Brasil (como os meios de comunicação)

No artigo 106, o estrangeiro fica ainda proibido de realizar qualquer atividade política, seja em suas práticas, seja no desenvolvimento ou na circulação de ideias:

Art. 106. O estrangeiro admitido no território nacional não pode exercer atividade de natureza política, nem se imiscuir, direta ou indiretamente, nos negócios públicos do Brasil, sendo-Ihe especialmente vedado:

I - organizar, criar ou manter sociedade ou quaisquer entidades de caráter político, ainda que tenham por fim apenas a propaganda ou a difusão, exclusivamente entre compatriotas, de idéias, programas ou normas de ação de partidos políticos do país de origem;

II - exercer ação individual, junto a compatriotas ou não, no sentido de obter, mediante coação ou constrangimento de qualquer natureza, adesão a idéias, programas ou normas de ação de partidos ou facções políticas de qualquer país; 
III - organizar desfiles, passeatas, comícios e reuniões de qualquer natureza, ou deles participar, com os fins a que se referem os itens I e II deste artigo.

Se o artigo 105 se caracteriza por uma distinção entre diferentes papéis temáticos, considerados incompatíveis, o artigo 106 marca a delimitação de determinados /fazeres/ (e /poder-fazer/ também) que não podem ser realizados pelo sujeito-estrangeiro.

Ao vetar a ação política do estrangeiro, a lei reforça a ideia de que o estrangeiro está no país apenas para trabalhar ou para se divertir. Além disso, não podemos esquecer que o processo de expulsão está diretamente relacionado a atividades políticas que podem ser consideradas ameaçadoras para a integridade nacional ${ }^{100}$.

Para finalizar esta seção, podemos dizer que o estrangeiro no Brasil não tem exatamente os mesmos direitos dos brasileiros natos. As restrições apresentadas por essa lei estabelecem que o estrangeiro não pode ter determinados estilos de vida ou realizar certos /fazeres/, orientando-o a viver de forma delimitada.

\section{Algumas considerações sobre a naturalização}

Como vimos na análise anterior, o processo de naturalização pode ser considerado como uma transformação de um indivíduo a partir do estabelecimento de um novo contrato entre Estado e estrangeiro. Dessa forma, um estrangeiro pode se tornar cidadão do país que ele escolhe para viver. Nesta seção, examinaremos as diferenças do processo de naturalização entre a lei 818 (anteriormente analisada) e o Estatuto do Estrangeiro. Além disso, veremos brevemente como as leis de outros países (Argentina, França e Estados Unidos) elaboram as exigências iniciais para um estrangeiro solicitar a naturalização.

Segundo a lei analisada, as condições a serem cumpridas pelo estrangeiro são as seguintes:

Art. 111. São condições para a concessão da naturalização:

\footnotetext{
${ }^{100}$ Segundo ainda o Estatuto do Estrangeiro, a pena para as infrações dos artigos 105 e 106 é de um a três anos de detenção e expulsão.
} 
I - capacidade civil, segundo a lei brasileira;

II - ser registrado como permanente no Brasil;

III - residência contínua no território nacional, pelo prazo mínimo de quatro anos, imediatamente anteriores ao pedido de naturalização;

IV - ler e escrever a língua portuguesa, consideradas as condições do naturalizando;

V - exercício de profissão ou posse de bens suficientes à manutenção própria e da família;

$\mathrm{VI}$ - bom procedimento;

VII - inexistência de denúncia, pronúncia ou condenação no Brasil ou no exterior por crime doloso a que seja cominada pena mínima de prisão, abstratamente considerada, superior a 1 (um) ano; e

VIII - boa saúde.

As únicas diferenças do artigo 111 do Estatuto do Estrangeiro em relação à lei 818 (artigo $8^{\circ}$ ) estão no tempo menor para se naturalizar (quatro anos no Estatuto do Estrangeiro e cinco anos na lei 818) e na obrigatoriedade de o estrangeiro estar registrado no país (exigência ausente na lei 818). A exigência de saber ler e escrever em língua portuguesa se mantém nessa lei, mas a exceção ao imigrante português não aparece no Estatuto.

Como o Estatuto do Estrangeiro é ainda a lei que regula a naturalização atualmente, parece-nos pertinente realizar uma rápida comparação com o processo de naturalização realizado em outros países. Para a comparação, selecionamos informações sobre as condições de naturalização na Argentina, na França e nos Estados Unidos.

$\mathrm{Na}$ Argentina $^{101}$, as exigências para naturalização são bastante simples. Há, basicamente, apenas duas exigências para o possível naturalizando (presentes no artigo $2^{\circ}$ ): a de residir no país durante dois anos contínuos e a de provar que o estrangeiro deu alguma contribuição ao país, como ter inventado algo útil ou instalado uma indústria. Além disso, há alguns papéis temáticos favorecidos no caso da naturalização: ser empresário, casar-se com argentina ou ser professor (em qualquer nível educacional) são considerados critérios para permitir ao estrangeiro se tornar argentino. Em nenhum momento a lei argentina se refere ao conhecimento da língua espanhola como necessário para a aquisição da nacionalidade.

As exigências para tornar-se cidadão francês estão presentes no Código Civil francês. Uma das primeiras exigências é a da residência em solo francês por cinco anos (artigo 21-17). Mas esse tempo pode ser reduzido a partir de

${ }^{101}$ A lei que trata da naturalização é a de número 346 "Ciudadania y Naturalización”. 
uma série de exceções: quando o estrangeiro comprovar dois anos de estudos em universidade francesa; provar talento e capacidade para servir a França; mostrar um percurso excepcional de integração nas esferas cívica, científica, econômica, cultural ou esportiva (artigo 21-18). Além disso, como fundamento para a naturalização, o estrangeiro deve mostrar conhecimento da língua, da história, da cultura e da sociedade francesas (artigo 21-24) e não ter cometido ato terrorista ou crime lesa pátria (artigo 21-27).

No caso dos Estados Unidos ${ }^{102}$, o tempo de residência também é de cinco anos. Além disso, a lei nos Estados Unidos exige também conhecimento da língua inglesa, da história norte-americana e boa moral (que pode ser entendida da seguinte maneira: ausência de crime, de ato terrorista, de prostituição, de poligamia, de jogo ilegal, de embriaguez habitual, de fraude, etc.).

Vemos que o processo de naturalização é mais simples na Argentina e mais complexo e exigente nos EUA e na França. Enquanto o Estado argentino não exige explicitamente o conhecimento da língua espanhola, as leis de naturalização francesa e norte-americana estabelecem o conhecimento da língua, mas também da história de cada país, como um dos fundamentos para se atribuir a naturalização ao estrangeiro.

Em relação às etapas burocráticas pelas quais o estrangeiro precisa passar, o Estatuto do Estrangeiro só difere da lei 818 pelo fato de não detalhar a entrega do certificado de naturalização e, portanto, não deixar claro se a exigência da leitura e da escrita de um trecho da Constituição perante o juiz ainda permanece. De qualquer forma, mantém-se a exigência de saber ler e escrever em português da lei anterior. Podemos, então, concluir que o processo de naturalização permanece praticamente o mesmo desde 1949.

\section{Considerações parciais}

Nesta análise, vimos como o Estatuto dos Estrangeiros organiza diferentes formas de estrangeiro por meio de distintos vistos. Cada um dos vistos tem como base uma temporalidade distinta (entre o permanente e o

\footnotetext{
${ }^{102}$ Tivemos acesso somente a um guia de naturalização e não à lei. Como em geral ocorre na legislação norte-americana, as exigências podem variar, e muito, de um estado a outro.
} 
transitório) e a autorização para se trabalhar ou não no país. A partir dessa tipologia do estrangeiro, o Estatuto organiza as interdições, as punições e os direitos e deveres do estrangeiro no país.

Basicamente, a interdição se refere ao impedimento da concessão do visto de entrada no país. No caso das punições, vimos as diferenças e as semelhanças entre a deportação, a expulsão e a extradição. A semelhança está no fato de todas essas punições apresentarem uma exclusão completa do país. A principal diferença é motivo que pode levar à exclusão. A deportação ocorre quando há uma infração referente ao visto. A expulsão, quando existe uma ameaça à integridade nacional. A extradição, quando um Estado estrangeiro solicita um determinado estrangeiro em solo nacional porque ele foi considerado culpado por algum crime.

Outra diferença importante entre essas formas de exclusão está no fato de a extradição envolver um processo mais longo até a saída do estrangeiro do país por haver a participação de dois Estados nacionais. A expulsão também envolve um julgamento antes de ser realizado, mas é mais curto que o da extradição.

Em relação às proibições, vimos que o estrangeiro não pode ter uma série de papéis temáticos, referentes, sobretudo, à propriedade e à atividade política. Dessa maneira, o Estatuto do Estrangeiro, a despeito de afirmar que o estrangeiro tem os mesmos direitos de um cidadão brasileiro, aplica limitações quanto ao estilo de vida do estrangeiro.

Essa restrição pode ainda ser vista no caso do registro. Assim, segundo a lei, o imigrante por vezes é proibido de mudar de profissão, assim como de mudar de residência, em determinadas situações. Em outras, o imigrante precisa informar ao Ministério da Justiça a mudança de residência. Além disso, vimos que algumas instâncias burocráticas (como a Junta Comercial, Cartórios de Registro Civil e estabelecimentos hoteleiros e imobiliários) precisam encaminhar informações sobre o estrangeiro ao Ministério da Justiça quando solicitadas.

Vimos que, a exigência de se saber ler e escrever em língua portuguesa, presente na lei 818, de 1949, continua presente no Estatuto do Estrangeiro. Essa exigência impõe limitações aos imigrantes que desejam se tornar 
brasileiros. Dessa forma, a lei mostra que é preciso ser alfabetizado em português para conseguir a naturalização ${ }^{103}$.

Examinamos, nesta seção, uma lei que trata de diferentes formas de estrangeiro. A seguir, analisaremos outra figura do estrangeiro que foi rapidamente tratada no Estatuto do Estrangeiro. Estamos nos referindo à imagem do refugiado.

\subsection{Estatuto dos refugiados}

\section{Introdução}

O refugiado é o indivíduo que precisa sair de seu país por conta de perseguições motivadas por divergências sociais, políticas, religiosas, raciais, etc. (Mello, 2002: 1053). Ainda segundo Mello, o refugiado tem "direito à vida, à propriedade, à liberdade de religião, de locomoção, exercer profissões liberais, ser comerciante, liberdade de associação, etc." (2002: 1056).

A figura do refugiado é, inclusive, mencionada na Declaração Universal dos Direitos do Homem, como podemos ver abaixo:

"1 - Todo homem, vítima de perseguição, tem o direito de procurar e de gozar asilo em outros países.

2 - Este direito não pode ser invocado em caso de perseguição legitimamente motivada por crimes de direito comum ou por atos contrários aos objetivos e princípios das Nações Unidas" (apud Mello, 2002: 1051).

Por conta do segundo item, Mello afirma que

"O asilo é concedido ao criminoso político, incluindo-se os que lutam contra o colonialismo. Não se dá asilo aos que cometeram crime de guerra, crime contra a paz e crime contra a humanidade" (Mello, 2002: 1054).

Pelo que foi dito até aqui, podemos ver algumas diferenças entre o refugiado e o asilado (tratado em dois artigos do Estatuto do Estrangeiro). A figura do refugiado é construída como a de um indivíduo perseguido por razões

\footnotetext{
${ }^{103}$ Em nossa dissertação de mestrado, vimos que o Decreto 200-A (de 8 de fevereiro de 1890) permitiu o alistamento eleitoral de brasileiros alfabetizados e de estrangeiros naturalizados e alfabetizados em sua língua de origem. Consequentemente, os analfabetos (brasileiros natos ou estrangeiros) foram excluídos do processo político (Bueno, 2006: 73).
} 
diversas (social, política, religiosa, racial, etc.) e, consequentemente, se pressupõe uma passividade inerente a essa figura. $O$ asilado se apresenta de modo um pouco diferente: sua figura está associada apenas ao campo político e infere-se que ele tenha cometido um crime político para ser reconhecido como um asilado ${ }^{104}$.

Trataremos, nesta análise, apenas da figura do refugiado. Para se chegar a todos os direitos previstos pelo Direito Internacional, o indivíduo que chega ao país na condição de refugiado precisa passar por um percurso que culmina no reconhecimento oficial pelo Estado brasileiro. Nesta análise, examinaremos como esse percurso é percorrido, segundo o que determina a lei, assim como a perda da condição de refugiado e as punições relativas a essa indivíduo no país.

\section{Resumo da lei}

Após 46 anos da publicação do Estatuto dos Refugiados pela ONU, o Brasil criou sua própria lei para aplicar os preceitos do Estatuto citado. A lei a que nos referimos é a de número 9.474, publicada em 22 de julho de 1997. Ela é composta por 49 artigos e trata juridicamente da definição e das condições do refugiado no Brasil. Veremos como o refugiado, enquanto uma outra forma de estrangeiro, possui tanto pontos em comum como diferenças em relação ao imigrante.

A primeira seção apresenta a definição de refugiado: aquele que é perseguido por causa de sua raça, de sua religião, de sua nacionalidade, de seu grupo social ou de sua opinião política e precisa sair ou fugir de seu país de origem por se sentir ameaçado. Veremos, em detalhes, a construção da imagem do refugiado em nossa análise

A segunda seção, constituída pelo artigo $2^{\circ}$, informa que os benefícios ao refugiado se estendem ao cônjuge, aos seus ascendentes e descendentes e aos demais dependentes do refugiado, desde que o acompanhem em sua entrada no Brasil. $\mathrm{O}$ artigo $3^{\circ}$ define os critérios que excluem um estrangeiro da

${ }^{104}$ Essa distinção entre asilado e refugiado é um tema em discussão pelo Direito Internacional. Mello aponta na Convenção da ONU de 1951 (que criou o Estatuto do Refugiado) momentos em que as duas imagens são consideradas equivalente e outros trechos em que são tratadas de forma distinta (2002: 1054). 
categoria de refugiado. Entre outras características, não pode ser reconhecido como refugiado o indivíduo que está sob proteção de organismo ou de instituição das Nações Unidas (com a exceção do Alto Comissariado das Nações Unidas para Refugiados); o que está já instalado no Brasil; o que tenha cometido algum crime hediondo, participado de ato terrorista ou tráfico de drogas.

Os artigos 4ำ, $5^{\circ}$ e $6^{\circ}$ legislam sobre a condição jurídica do refugiado. Em linhas gerais, o refugiado, segundo a lei, tem todos os direitos e os deveres dos estrangeiros no Brasil, assim como direito a documento de identidade, carteira de trabalho e documento de viagem.

A entrada do refugiado no Brasil é tratada nos artigos $7^{\circ}$ ao 10. Veremos, no decorrer de nossa análise, detalhes sobre a entrada do refugiado no país.

O artigo 11 cria o Comitê Nacional para Refugiados (CONARE), cuja premissa é a de ser um "órgão de deliberação coletiva, no âmbito do Ministério da Justiça". Já as responsabilidades do CONARE estão previstas nos artigos 12 a 16.

Os artigos 17 a 20 retomam com um maior detalhamento o processo de pedido de refúgio. Os artigos 21 e 22 tratam da autorização de residência provisória do refugiado. Nesses dois artigos, fica decido que a Polícia Federal e o Ministério do Trabalho são os auxiliares diretos do refugiado para ele se instalar, ainda provisoriamente, no país. Os artigos 23, 24 e 25 tratam de questões mais burocráticas, como a verificação das informações prestadas pelo refugiado, assim como os trâmites burocráticos no CONARE (que analisa a validade do pedido de reconhecimento da condição de refugiado).

Os artigos 26, 27 e 28 tratam da decisão, da comunicação e do registro do refugiado. Os casos de recusa ao reconhecimento de sua condição de refugiado podem ser revistos por meio de recurso à sentença. Essa questão é tratada nos artigos 29 a 32.

A lei trata ainda da questão da extradição e da expulsão do refugiado nos artigos 33 a 37 . Veremos, em nossa análise, como a lei trata dessa questão. 
Há ainda a possibilidade de se interromper o reconhecimento da condição de refugiado por decisão do CONARE. Isso está regulamentado no artigo 38, que apresenta as situações em que pode ocorrer essa interrupção.

O artigo 39 trata especificamente da perda da condição de refugiado. Veremos, em detalhes, essas condições em nossa análise. $O$ artigo 40 determina que o CONARE deve ser a primeira instância decisória sobre a interrupção ou a perda da condição de refugiado. No artigo 41, fica determinado que a decisão final do Ministério da Justiça é soberana e deve ser imediatamente comunicada ao CONARE, que informa ao estrangeiro e à Polícia Federal qual foi a decisão final do recurso.

O artigo 42 diz que a repatriação deve ser considerada um ato voluntário de retorno, ou seja, deve existir a vontade do refugiado em retornar ao seu país de origem. Mas o artigo considera a possibilidade de repatriação obrigatória, no sentido de ser um retorno ao seu país de origem quando estiver em paz ou quando não apresentar mais a situação social e política que motivou a saída do refugiado.

A condição atípica do refugiado permite uma flexibilização da exigência dos documentos emitidos pelos países de origem ou por suas representações diplomáticas e consulares (artigo 43).

O artigo 44 determina a facilitação do reconhecimento de certificados e de diplomas, quando estes são exigidos para ingresso em instituições acadêmicas de quaisquer níveis, por conta da situação peculiar do refugiado.

O artigo 45 e 46 tratam do reassentamento do refugiado. Já nas disposições gerais dessa lei, o artigo 47 determina a gratuidade e a urgência do processo de reconhecimento da condição de refugiado. $O$ artigo 48 diz que a presente lei está em sintonia com a Declaração Universal dos Direitos do Homem de 1948, com a Convenção sobre o Estatuto dos Refugiados de 1951, com o Protocolo sobre o Estatuto dos Refugiados de 1967 e com qualquer outro dispositivo internacional de proteção aos direitos humanos com o qual o Governo brasileiro esteja comprometido. Por fim, como em toda lei, o artigo final, o de número 49, determina que essa lei passa a valer a partir de sua data de publicação. 


\section{Considerações sobre a construção discursiva do refugiado}

A lei apresenta no artigo $1^{\circ}$ três itens para definir quem pode ser considerado refugiado, como vemos abaixo:

Art. 1 o Será reconhecido como refugiado todo indivíduo que:

I - devido a fundados temores de perseguição por motivos de raça, religião, nacionalidade, grupo social ou opiniões políticas encontre-se fora de seu país de nacionalidade e não possa ou não queira acolher-se à proteção de tal país; II - não tendo nacionalidade e estando fora do país onde antes teve sua residência habitual, não possa ou não queira regressar a ele, em função das circunstâncias descritas no inciso anterior;

III - devido a grave e generalizada violação de direitos humanos, é obrigado a deixar seu país de nacionalidade para buscar refúgio em outro país.

Do que foi citado acima, podemos reter algumas características. O refugiado é definido, inicialmente, por um traço passional: ele é um sujeito que teme pela própria integridade física e pela vida, pois se sente ameaçado. Essa ameaça se configura pelo /fazer malevolente/ de um antissujeito contra o qual o refugiado não tem condições de se opor (por exemplo, um regime político, o próprio Estado, grupos religiosos, etc.). Por não conseguir competir com o antissujeito em termos de força e de competência modal (o refugiado pode ser considerado um sujeito do /saber-não-poder-fazer/), a única possibilidade de sobreviver é saindo do seu país de origem.

Nessa questão da perseguição ao refugiado, estão presentes diferentes temas, como o racismo, a intolerância religiosa, a xenofobia, o preconceito social ou a perseguição política. Esses temas estão no início do processo que leva o sujeito a se transformar em um refugiado, uma vez que eles subsumem programas narrativos que visam à exclusão e mesmo à eliminação de um determinado sujeito, rompendo assim o contrato que o ligava à sua nacionalidade e ao seu país. Em suma, podemos dizer que o refugiado é consequência da intolerância presente em seu país de origem.

Pela presença de antissujeitos, esse sujeito é excluído ou se exclui do percurso narrativo que caracteriza sua vida em seu país de origem. A mudança de percurso narrativo, do seu país ao Brasil, provoca uma transformação: de um cidadão que é perseguido em seu próprio país, por ser considerado indesejado pelos motivos acima descritos (no item I), em um estrangeiro em busca de abrigo. 
A mesma configuração de perseguição é encontrada no item II, com a diferença de que esse sujeito não possui o contrato com seu país de origem porque não tem uma nacionalidade, mas se encontra em um espaço social determinado ("sua residência habitual") em um determinado país, mesmo que não seja o de origem. Já o item III não chega exatamente a mudar o tema da perseguição, mas o complementa por meio de uma menção à ruptura dos direitos humanos (já que formas de exclusão como o racismo, a xenofobia, intolerância social, religiosa e política também infringem os preceitos dos direitos humanos).

Dessa forma, o refugiado é um sujeito, em nossa concepção, a procura de um novo percurso narrativo (e, consequentemente, de novos valores) porque, característica comum aos três itens que o definem, ele é um sujeito excluído de outro programa narrativo por diferentes motivos e razões.

$O$ refugiado e o imigrante são ambos estrangeiros que se estabelecem definitivamente no país. $O$ refugiado difere do imigrante e se apresenta como outra forma de ser estrangeiro e de alteridade, pois não tem condições de voltar (seja por desejo, seja por necessidade) ao seu percurso narrativo anterior, ao contrário do imigrante que, se não realiza esse retorno frequentemente, ao menos pode voltar quando tem condições ou vontade. Em outras palavras, enquanto o refugiado não tem como voltar ao seu percurso narrativo anterior, o imigrante pode fazê-lo, pois há sempre algum tipo de ligação com seu país de origem, com os familiares que lá ficaram e com os valores com os quais ele se identifica ou que ele aprendeu a sentir como sendo seus. Além disso, o imigrante é frequentemente caracterizado por seu /fazer/, ou seja, por ser um trabalhador estrangeiro que se estabelece no país, enquanto no refugiado a ênfase recai em sua característica de "sujeito perseguido". Por conta dessa diferença, veremos no decorrer da análise como o Estatuto do Refugiado apresenta traços mais "humanitários" em oposição a um discurso "pragmático" (no sentido de enfatizar o trabalho do imigrante), presente no Estatuto do Estrangeiro (e em outros textos que tratam da imigração).

$\mathrm{Na}$ perspectiva do Estado brasileiro, vemos que ele pode escolher os imigrantes que vão entrar e se fixar no país. No caso do refugiado, o governo brasileiro não pode fazer essa escolha ou, ao menos, não pode estabelecer 
muitos critérios para a entrada do refugiado no país. Mais uma diferença importante entre refugiado e imigrante é que a condição do primeiro é diretamente estendida à sua família e demais membros que o acompanham (conforme o artigo $2^{\circ}$ ), enquanto o segundo pode até entrar com sua família, mas cada um deve necessariamente passar pelas mesmas etapas e processos para ser imigrante no Brasil, algo que não ocorre com o refugiado. Parece-nos que esses dois casos podem ser usados para embasar a configuração mais humanitária da lei referente ao refugiado.

Todas as características até aqui mencionadas a respeito do sujeitorefugiado fazem parte de sua definição explicitada na lei. Como dissemos acima, outros elementos podem ser convocados para enriquecer a definição desse sujeito à partir dos percursos organizados pela lei. São justamente esses percursos que veremos abaixo.

\section{Percursos para se tornar refugiado: em busca do reconhecimento}

Para adquirir o papel-temático de refugiado, o sujeito perseguido em outro país necessita do reconhecimento por parte de quem o recebe. Esse sujeito perseguido deve, assim, cumprir um determinado percurso narrativo burocrático estabelecido pela lei analisada.

Inicialmente, o sujeito-refugiado precisa saber (ter consciência) de sua condição mesma, pois ele deve identificar-se como refugiado a uma autoridade competente que representa o governo brasileiro no serviço de imigração. Assim, refugiado é aquele que se diz refugiado, em um primeiro momento, diante da autoridade competente que vai então realizar um breve fazerinterpretativo. É isso o que nos mostra o artigo $7^{\circ}$ :

Art. $7^{\circ} \mathrm{O}$ estrangeiro que chegar ao território nacional poderá expressar sua vontade de solicitar reconhecimento como refugiado a qualquer autoridade migratória que se encontre na fronteira, a qual lhe proporcionará as informações necessárias quanto ao procedimento cabível.

$\S 1$ 으 hipótese alguma será efetuada sua deportação para fronteira de território em que sua vida ou liberdade esteja ameaçada, em virtude de raça, religião, nacionalidade, grupo social ou opinião política.

$\S 2^{\circ} \mathrm{O}$ benefício previsto neste artigo não poderá ser invocado por refugiado considerado perigoso para a segurança do Brasil. 
Dessa forma, após identificar-se como um refugiado, a autoridade competente realiza um fazer-interpretativo em que reconhece ou não (sanção cognitiva) essa condição do refugiado para dar uma primeira assistência (sanção pragmática). Há, contudo, outro elemento que pode interferir na sanção pragmática: a mencionada assistência pode ser negada se o solicitante for considerado um indivíduo perigoso à nação brasileira (mesmo se for reconhecida a sua condição de refugiado), conforme o segundo parágrafo do artigo acima citado.

Ao ser aceito como refugiado, sem riscos para o país, o sujeito solicitante ganha, em outra sanção pragmática, dois benefícios imediatos: a de não poder ser deportado em direção ao país de onde fugiu (primeiro parágrafo do artigo $7^{\circ}$ ); a suspensão ou a impossibilidade de sofrer um processo por entrada irregular no Brasil (artigo $8^{\circ}$ ). Esse último benefício é ainda explicitamente estendido aos familiares e demais pessoas que estejam acompanhando o refugiado (conforme o primeiro parágrafo do artigo 10).

\begin{abstract}
Art. 10. A solicitação, apresentada nas condições previstas nos artigos anteriores, suspenderá qualquer procedimento administrativo ou criminal pela entrada irregular, instaurado contra o peticionário e pessoas de seu grupo familiar que o acompanhem.

$\S 1^{\circ}$ Se a condição de refugiado for reconhecida, o procedimento será arquivado, desde que demonstrado que a infração correspondente foi determinada pelos mesmos fatos que justificaram o dito reconhecimento. $\S 2^{\circ}$ Para efeito do disposto no parágrafo anterior, a solicitação de refúgio e a decisão sobre a mesma deverão ser comunicadas à Polícia Federal, que as transmitirá ao órgão onde tramitar 0 procedimento administrativo ou criminal.
\end{abstract}

Uma terceira sanção pragmática é aplicada ao sujeito-refugiado. Assim, ele recebe uma autorização de residência provisória por parte da Polícia Federal, segundo os artigos 21 e 22. Durante esse período provisório, o refugiado é considerado somente um estrangeiro, estando sujeito às leis relativas a estrangeiros no país.

Depois de estabelecido esse rápido percurso, o refugiado precisa ainda apresentar elementos para comprovar, como em um fazer-veridictório, sua condição de refugiado e adquirir a permissão definitiva para permanecer no Brasil. Para isso, ele deve fazer um depoimento, se necessário com a ajuda de um intérprete, além de apresentar documentos, conforme o artigo 19: 
Art. 19. Além das declarações, prestadas se necessário com ajuda de intérprete, deverá o estrangeiro preencher a solicitação de reconhecimento como refugiado, a qual deverá conter identificação completa, qualificação profissional, grau de escolaridade do solicitante e membros do seu grupo familiar, bem como relato das circunstâncias e fatos que fundamentem o pedido de refúgio, indicando os elementos de prova pertinentes.

Pelo trecho acima, vemos que a prova de veracidade de sua condição de refugiado pode ter duas formas: uma, mais objetiva, envolve a apresentação de documentos; a outra, mais subjetiva, se refere à história pessoal do refugiado, contada por ele.

Comparada ao estrangeiro, a entrada do refugiado no país parece ser mais simplificada. O estrangeiro, independente do tipo de visto solicitado, precisa mostrar algumas características para ter seu pedido atendido: ser maior de idade, não ser considerado uma ameaça, não ter sido expulso do país nem condenado em outro país e apresentar boa condição de saúde. Para o refugiado, o único item que pode impedir a sua entrada no país é ser considerado uma ameaça ao país (e, ainda assim, ele não é devolvido ao seu país de origem).

Vimos, até aqui, dois percursos narrativos envolvendo o refugiado: o da chegada, mais curto e de caráter provisório, e 0 do processo de reconhecimento definitivo, mais longo e dotado de diferentes etapas, em que a burocracia governamental decide sobre a permanência definitiva no Brasil. É dessa segunda etapa que trataremos a seguir, sob o ponto de vista do próprio governo brasileiro, segundo a lei.

\section{Percursos do governo brasileiro: processos burocráticos}

Os dois percursos do refugiado acima mencionados envolvem a interação com o Estado brasileiro, seja pela figura de um funcionário público seja pela presença instaurada pela lei de instâncias burocráticas (como os Ministérios da Justiça e do Trabalho e o CONARE). Para um /fazer/ do refugiado, há também um /fazer-interpretativo/ do governo brasileiro, por meio de adjuvantes instituídos no discurso jurídico. Assim, a partir dos documentos apresentados pelo refugiado, a estrutura jurídica e governamental julga a validade ou não de seu pedido. Trata-se, assim, de todo um processo de 
julgamento, em que se reforça a sanção cognitiva e se apresenta também outra sanção pragmática, distinta das anteriores, que se refere à permanência definitiva ou não do refugiado (e de eventuais parentes e acompanhantes) no Brasil.

Para realizar essa sanção, o discurso instaura diferentes actantes que cumprem cada qual uma determinada função. De certa forma, eles auxiliam na sanção final do refugiado, não apenas em relação à análise dos documentos (que está ligada ao /parecer-ser-verdadeiro/), mas também a outras questões, como veremos a seguir.

Aos diferentes actantes instaurados pelo enunciador, como a Polícia Federal, os juízes, os Ministérios da Justiça e do Trabalho, funcionário da imigração, vem formar-se um novo órgão burocrático criado pelo próprio Estatuto do Refugiado, o Comitê Nacional para os Refugiados (CONARE). A lei organiza discursivamente toda a estrutura do CONARE, atribuindo-lhe funções e modos de realizá-las, assim como seleciona e determina quais os elementos que devem fazer parte da instância decisória (como mencionado na lei, diferentes Ministérios indicam membros para o conselho).

O CONARE passa a ser o responsável pela análise e a consequente recusa ou aprovação dos pedidos e também pela cassação e perda do reconhecimento da condição de refugiado. Além disso, é responsável pela aplicação de ações relativas à proteção e à assistência ao refugiado. Por essa razão, o CONARE sincretiza a função de julgador e a de adjuvante do refugiado. Na função de destinador-julgador, o CONARE é a etapa final de todo o percurso pelo qual o sujeito refugiado deve passar.

O Ministério da Justiça, nessa lei, tem o papel de "super-destinador", na medida em que o CONARE está subordinado a esse ministério, que tem ainda a função de sancionar positivamente o julgamento realizado pelo CONARE ou de mudá-lo, quando há solicitação de recurso em casos de negação do reconhecimento da condição do refugiado.

Mesmo sem apresentar uma série de exigências, como as aplicadas aos imigrantes, a lei ainda legisla sobre a possibilidade de perda da condição de refugiado, sua extradição e sua expulsão (mesmo que seja para proibir essas formas de exclusão). São esses elementos que veremos a seguir, tentando ressaltar as diferenças entre essas punições e as aplicadas ao imigrante. 


\section{Extradição, expulsão, cessação e perda: formas de disjunção}

Da mesma forma que está presente no Estatuto do Estrangeiro, a lei sobre os refugiados também faz menções à possibilidade de expulsão e de extradição. A diferença é que, no caso do refugiado, nenhuma dessas duas formas de exclusão pode ser aplicada pelos mesmos critérios encontrados no Estatuto do Estrangeiro. A expulsão só é acionada se o refugiado for considerado um perigo para o país. Mesmo nesse caso, como vimos, ele não pode ser reconduzido ao seu país de origem e só pode ser efetivamente expulso se não houver qualquer risco de perseguição no país que aceite recebê-lo, como vemos abaixo no artigos:

Art. 33. O reconhecimento da condição de refugiado obstará o seguimento de qualquer pedido de extradição baseado nos fatos que fundamentaram a concessão de refúgio.

Art. 34. A solicitação de refúgio suspenderá, até decisão definitiva, qualquer processo de extradição pendente, em fase administrativa ou judicial, baseado nos fatos que fundamentaram a concessão de refúgio.

Art. 35. Para efeito do cumprimento do disposto nos arts. 33 e 34 desta Lei, a solicitação de reconhecimento como refugiado será comunicada ao órgão onde tramitar o processo de extradição.

Art. 36. Não será expulso do território nacional o refugiado que esteja regularmente registrado, salvo por motivos de segurança nacional ou de ordem pública.

Art. 37. A expulsão de refugiado do território nacional não resultará em sua retirada para país onde sua vida, liberdade ou integridade física possam estar em risco, e apenas será efetivada quando da certeza de sua admissão em país onde não haja riscos de perseguição.

A expulsão e o reconhecimento da condição de refugiado são dois regimes de sentido incompatíveis nesse discurso. De uma maneira geral, o ato de se tornar um refugiado automaticamente interdita a possibilidade de exclusão do espaço social e geográfico brasileiro. Essa característica é uma das configurações do contrato fiduciário estabelecido entre refugiado e Estado brasileiro. No caso em que ocorra a ruptura do contrato, por ser o refugiado considerado um sujeito de /fazer-malevolente/ contra o Brasil, ele é excluído de sua condição de refugiado e deve deixar o país. Como vimos no caso do 
imigrante, a expulsão ocorre quando ele é considerado uma ameaça à ordem nacional.

A diferença entre o imigrante e o refugiado está na questão da extradição. Como esse regime de disjunção ocorre entre dois Estados nacionais, o refugiado não pode ser extraditado e qualquer processo contra ele nesse sentido é bloqueado no país.

Há ainda outras formas de o refugiado perder sua condição, por meio da finalização do contrato entre ele e o Estado brasileiro: a cessação e a perda. Nesses dois casos, a ruptura do contrato não implica a exclusão espacial, como no caso da expulsão. A ruptura do contrato incide sobre o próprio /ser/ do sujeito-refugiado, que passa a um /não-ser-refugiado/. Veremos abaixo como se organizam as diferenças entre as duas formas.

A cessação da condição de refugiado ocorre quando o refugiado volta ao seu país de origem. No momento em que ele pode e quer retornar ao seu programa narrativo anterior, o sujeito-refugiado rompe o contrato com o Estado brasileiro porque ele não é mais um sujeito sob o risco de ser punido e, assim, o temor desse sujeito desaparece ao mesmo tempo em que ele recobra a confiança para retornar a seu país de origem. Ocorre a cessação também quando o sujeito refugiado decide partir para outro programa narrativo que não é mais o do Estado brasileiro. Em outras palavras, quando ele decide adquirir a nacionalidade de outro país, que não é nem a brasileira nem a de origem, como podemos ver no artigo abaixo:

Art. 38. Cessará a condição de refugiado nas hipóteses em que o estrangeiro: I - voltar a valer-se da proteção do país de que é nacional; II - recuperar voluntariamente a nacionalidade outrora perdida;

III - adquirir nova nacionalidade e gozar da proteção do país cuja nacionalidade adquiriu;

IV - estabelecer-se novamente, de maneira voluntária, no país que abandonou ou fora do qual permaneceu por medo de ser perseguido;

V - não puder mais continuar a recusar a proteção do país de que é nacional por terem deixado de existir as circunstâncias em conseqüência das quais foi reconhecido como refugiado;

VI - sendo apátrida, estiver em condições de voltar ao país no qual tinha sua residência habitual, uma vez que tenham deixado de existir as circunstâncias em conseqüência das quais foi reconhecido como refugiado.

Em todos os casos, a cessação, ou seja, o fim de sua condição de refugiado, tem em sua base uma transferência de programa narrativo: do 
desenvolvido no Brasil para o de outro país, seja o de origem do refugiado, seja outro escolhido por sua própria vontade ou por algum outro esquema de manipulação (quando, hipoteticamente, ocorre o fim de todas as condições que ameaçavam sua própria vida). Apesar de não estar explicitado na lei, o Estado brasileiro deve estar ciente dessa mudança para que o refugiado possa partir para outros programas narrativos sem qualquer prejuízo para o próprio refugiado.

A perda da condição de refugiado apresenta algumas diferenças em relação à cessação. Para facilitar a análise, citamos nominalmente o artigo que trata da perda da condição de refugiado:

Art. 39. Implicará perda da condição de refugiado:

I - a renúncia;

II - a prova da falsidade dos fundamentos invocados para o reconhecimento da condição de refugiado ou a existência de fatos que, se fossem conhecidos quando do reconhecimento, teriam ensejado uma decisão negativa;

III - o exercício de atividades contrárias à segurança nacional ou à ordem pública;

IV - a saída do território nacional sem prévia autorização do Governo brasileiro.

A retirada da condição de refugiado pode ocorrer no caso em que o próprio refugiado renuncia à sua condição. Dessa forma, por meio de um /querer-não-ser/, o refugiado renega seu papel temático e rompe o contrato com o Estado brasileiro. A diferença é que, nesse caso, não há necessariamente a saída do país, apenas a perda de sua condição, que passa de um ser-refugiado para um não-ser-refugiado (ele pode se tornar imigrante ou mesmo cidadão brasileiro, por exemplo).

A perda pode também ser compreendida como uma punição nas outras três situações apontadas na lei. A primeira pode ser acionada quando comprovada, por meio de um /fazer-interpretativo/ do Estado brasileiro, a falsidade dos documentos apresentados para obtenção da condição de refugiado. A segunda, quando o sujeito é sancionado negativamente por um fazer considerado prejudicial à nação brasileira (mais especificamente, à segurança nacional e à ordem pública). A terceira forma de punição surge quando o sujeito-refugiado sai do território nacional sem o conhecimento do governo brasileiro. Ocorre, assim, uma clara "quebra" de contrato entre o 
refugiado e o Estado brasileiro ${ }^{105}$. As punições são explicitadas no parágrafo único do artigo 39.

Parágrafo único. Os refugiados que perderem essa condição com fundamento nos incisos I e IV deste artigo serão enquadrados no regime geral de permanência de estrangeiros no território nacional, e os que a perderem com fundamento nos incisos II e III estarão sujeitos às medidas compulsórias previstas na Lei no 6.815, de 19 de agosto de 1980 .

Nos casos de renúncia à condição de refugiado e/ou de saída do país, o refugiado passa a estar sujeito à lei dos estrangeiros, perdendo assim alguns direitos (ou privilégios) específicos do refugiado. Nos casos de falsificação de documentos ou de ameaça à segurança ou à ordem pública envolvem as punições previstas na lei 6.815 , de 19 de agosto de 1980 . Com base no Estatuto do Estrangeiro, podemos observar que as punições são a reclusão de um a 5 cinco anos e, em seguida, a expulsão (no caso dos documentos falsos) e a proibição de voltar ao país como refugiado.

De uma maneira geral, a diferença entre a cessação e a perda está no modo como o contrato entre refugiado e Estado brasileiro é interrompido. $\mathrm{Na}$ cessação, o contrato é como que finalizado pelo refugiado por causa da mudança de percurso narrativo. Na perda da condição de refugiado, há uma espécie de ruptura porque o sujeito-refugiado realiza ações contrárias aos elementos que fundamentaram o próprio contrato entre ele e o Estado brasileiro. Além disso, a ruptura de contrato pode ocorrer por vontade do próprio refugiado, quando ele renuncia à sua condição. Principalmente pela primeira característica, a perda da condição de refugiado tem, nessa lei, uma característica mais "punitiva" do que a cessação.

\section{Repatriação e fixação definitiva do refugiado}

$\mathrm{Na}$ parte final da lei, há ainda três questões pertinentes a serem tratadas: a da repatriação, a do reassentamento e a da integração definitiva. A repatriação tem, como a expulsão e a extradição, um caráter de exclusão, mas difere das duas formas anteriores por não ter um traço de contravenção.

${ }^{105}$ Esse caso é semelhante ao visto na lei 818 , referente à perda da nacionalidade. 
Segundo a lei, a repatriação deve ter, sempre que possível, um caráter voluntário (artigo 42), ou seja, deve estar sempre envolvida a modalidade do /querer-fazer/ e do /querer-ser/ do refugiado:

Art. 42. A repatriação de refugiados aos seus países de origem deve ser caracterizada pelo caráter voluntário do retorno, salvo nos casos em que não possam recusar a proteção do país de que são nacionais, por não mais subsistirem as circunstâncias que determinaram o refúgio.

Deve, assim, prevalecer o desejo do refugiado em retornar ao seu país de origem. É também possível, ainda no caso da repatriação, que o refugiado seja repatriado quando seu país de origem não apresenta mais as condições de ameaça a ele e, assim, ele não pode mais negar a proteção de seu país de origem. Nesse caso, a repatriação envolve a modalidade do /dever-fazer/ e do /dever-ser/ do refugiado, que se sente na obrigação de retornar ao seu país de origem. Ao mesmo tempo, segundo a lei, o ato de repatriação significa o fim do contrato entre Estado brasileiro e refugiado e, assim, se um dia desejar retornar ao Brasil, esse ex-refugiado pode entrar na qualidade de estrangeiro.

No caso do reassentamento, há duas possibilidades: o reassentamento do refugiado em outro país ou do refugiado no Brasil. Vejamos o que dizem os dois artigos que tratam dessa questão:

\begin{abstract}
Art. 45. O reassentamento de refugiados em outros países deve ser caracterizado, sempre que possível, pelo caráter voluntário.

Art. 46. O reassentamento de refugiados no Brasil se efetuará de forma planificada e com a participação coordenada dos órgãos estatais e, quando possível, de organizações não-governamentais, identificando áreas de cooperação e de determinação de responsabilidades.
\end{abstract}

No primeiro caso, o reassentamento deve também ter um caráter voluntário, isto é, um /querer-fazer/ e um /querer-ser/. Além disso, apesar de não estar explícito na lei, esse caso se refere aos refugiados sob a proteção do Alto Comissariado das Nações Unidas para o Refugiado (ACNUR), por exemplo. Por isso, ele pode optar por ir para outro Estado nacional, caso seja sua vontade. No segundo caso, está prevista a participação coordenada dos órgãos estatais (e, em alguns casos, de organizações não-governamentais) como adjuvantes para se planejar e executar a melhor forma de se fixar o refugiado. 
Por fim, a integração é referida nos artigos 43 e 44. Esses dois artigos tratam de duas "facilidades" aplicadas ao refugiado:

Art. 43. No exercício de seus direitos e deveres, a condição atípica dos refugiados deverá ser considerada quando da necessidade da apresentação de documentos emitidos por seus países de origem ou por suas representações diplomáticas e consulares.

Art. 44. O reconhecimento de certificados e diplomas, os requisitos para a obtenção da condição de residente e o ingresso em instituições acadêmicas de todos os níveis deverão ser facilitados, levando-se em consideração a situação desfavorável vivenciada pelos refugiados.

No artigo 43, se deve levar em consideração a situação peculiar (o rompimento do contrato anterior com seu país de origem) quando se exigir a apresentação de documentos do refugiado. No artigo 44, o reconhecimento de diplomas e certificados também deve ser facilitado quando for o caso de ingresso em instituições acadêmicas (aqui não fica claro que se é para trabalhar ou estudar). De qualquer forma, os dois artigos mostram a necessidade de se considerar a situação inusitada do refugiado para não prejudicá-lo em sua buscar de uma nova vida no país.

Em ambos os casos, se vê como o papel temático influencia na atenuação de certas exigências advindas do destinador-julgador, como formas veridictórias de comprovação das modalidades do /saber/ que se refletem na modalidade do /poder-fazer/. Em outras palavras, a competência do sujeitorefugiado é avaliada sob um prisma um pouco distinto da do imigrante. No caso do refugiado, a sanção sobre sua competência não é tão "rigorosa" por se saber que a própria organização modal do refugiado é incompleta por ser um sujeito que é obrigado a se transferir de programa narrativo contra sua própria vontade.

\section{De estrangeiro a refugiado: síntese dos percursos}

Como pudemos ver nessa lei, o refugiado difere juridicamente do imigrante. $O$ Estatuto do Estrangeiro nos permitiu pensar no imigrante como uma forma particular de estrangeiro, categoria que engloba também a de refugiado. Veremos nessa seção como o refugiado se define a partir dessa categoria maior, a do estrangeiro, a partir das próprias considerações da lei. 
Inicialmente, todo refugiado chega na condição mesma de estrangeiro. Ele só é reconhecido como refugiado se assim se declarar perante um funcionário do Estado brasileiro quando for entrar no país. Como já observamos acima, essa declaração ainda não é suficiente para ele ser considerado verdadeiramente um refugiado pelo Estado brasileiro, tanto que o refugiado recebe autorização provisória para residir e trabalhar no Brasil. Por essas razões, podemos pensar que, nessa fase de sua situação para entrar e se estabelecer no Brasil como refugiado, o sujeito-refugiado fica a meio caminho de deixar de ser um estrangeiro para se tornar um refugiado.

É a partir dessa fase intermediária e provisória que o sujeito em busca do reconhecimento pode iniciar o processo para adquirir sua identidade de refugiado, como vimos anteriormente. Nessa etapa, ele vai precisar provar a distintas instâncias burocráticas do governo brasileiro que sua condição de perseguido é real e verdadeira.

Depois de se tornar oficialmente um refugiado, com o reconhecimento do Estado brasileiro, a lei mostra as possibilidades de ele perder esse status, seja pela interrupção seja pela perda propriamente dita. No caso da interrupção, pode-se compreendê-la como estando a meio caminho de sua volta à condição de estrangeiro. No caso da perda, ele volta a ser definitivamente um estrangeiro, seja em solo brasileiro seja fora dele. Assim, podemos pensar no seguinte esquema para se compreender os percursos possíveis do refugiado no Brasil:

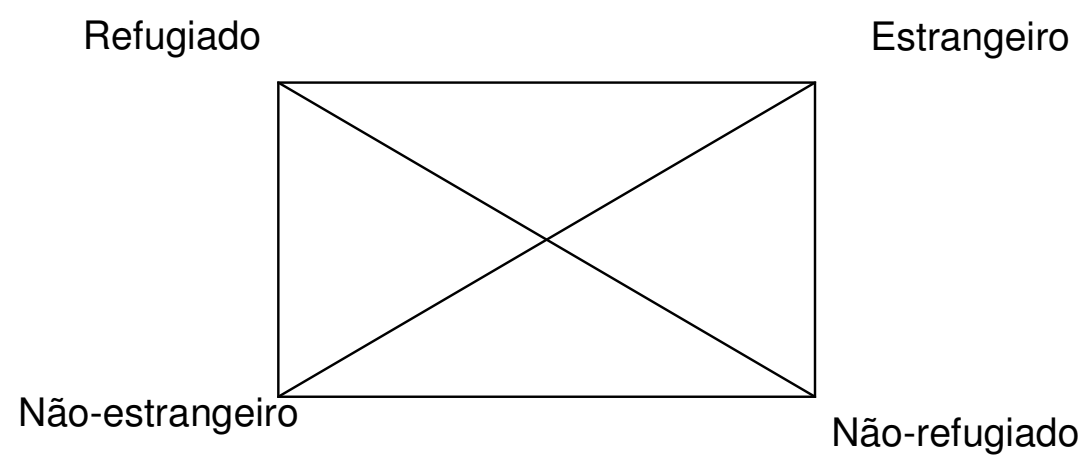

O percurso que começa no termo "estrangeiro" e vai até sua negação é o percurso da chegada desse refugiado. Assim, esse é o momento em que o 
estrangeiro fugido de seu país se afirma como refugiado e é autorizado a entrar no país com essa condição ainda provisória. Ele só passa a ser efetivamente um refugiado reconhecido pelo Estado quando recebe a sanção final no percurso que parte do "não-estrangeiro" e chega ao termo "refugiado".

Quando o Estado brasileiro decide pela interrupção de sua condição de refugiado, ocorre o movimento que parte do termo "refugiado" para "nãorefugiado". Por fim, a passagem do termo "não-refugiado" para estrangeiro significa a perda definitiva de sua condição de refugiado. É a partir desse percurso que ocorrem as operações de exclusão espacial, como a repatriação, ou simbólica (quando ele permanece no Brasil, mas como estrangeiro).

Dessa forma, mesmo em uma lei que trata juridicamente de apenas uma figura da alteridade, como essa lei, é possível construir uma rede de relações que geram os percursos pelos quais ele precisa passar no espaço brasileiro.

\section{Considerações parciais}

Vimos, nesta análise, que o refugiado é uma figura particular de estrangeiro. Ele difere desta principalmente por causa de seu papel temático: 0 refugiado é, assim, um sujeito perseguido que necessita ir para outro país para preservar sua integridade física.

Por conta de sua condição peculiar, o Estatuto do Refugiado apresenta traços mais humanistas para recebê-lo no país. Assim, ao refugiado é concedida uma série de facilidades para entrar e se estabelecer no país. O refugiado pode chegar (com sua família e demais acompanhantes) ao país e solicitar o reconhecimento de sua condição para poder entrar sem necessidade de visto ou de qualquer outra exigência estabelecida para os estrangeiros em geral.

O Estado brasileiro, ao reconhecer a condição do refugiado, apresenta ainda auxílios para sua instalação e para a procura de um trabalho (como, por exemplo, emitir, sem grandes percalços burocráticos, documento de identificação e de trabalho). Além disso, a lei ainda apresenta claramente a proibição de se aplicar qualquer forma de exclusão, como a deportação e a extradição. 
Por fim, é interessante observar que pela lei o refugiado não necessita apresentar, para obter seu reconhecimento, traços relativos à questão cultural, ao conhecimento da língua portuguesa ou à capacidade para o trabalho.

\section{Conclusões do capítulo}

As leis analisadas neste capítulo foram selecionadas com o intuito de apresentar diferentes aspectos relacionados à presença do estrangeiro no país. Além do mais, optamos por contemplar épocas diferentes, desde o período subsequente ao final da Segunda Guerra Mundial até os dias atuais.

Vimos como as leis constroem basicamente duas representações do estrangeiro no país. As leis elaboram a imagem do estrangeiro como um indivíduo bom para permanecer e, por vezes, se integrar ao país, e como uma possível ameaça à integridade nacional. Indiretamente, as leis também constroem a imagem do "bom brasileiro" a partir das exigências necessárias para um estrangeiro adquirir a nacionalidade brasileira.

As condições necessárias para a naturalização são basicamente idênticas entre a lei 818 (de 1949) e a lei 6.815 (de 1980). Ambas exigem capacidade civil, residência em território nacional, bom procedimento, exercício de profissão, ausência de processos ou condenações em outros países e conhecimento da língua portuguesa. Chama-nos a atenção que as exigências para se solicitar a naturalização permanecem, praticamente, as mesmas em um intervalo de mais de trinta anos entre as leis e mais de sessenta anos se pensarmos que o Estatuto do Estrangeiro continua em vigência nos dias atuais. Como vimos no começo da seção referente ao Estatuto do Estrangeiro, a lei é considerada anacrônica por boa parte dos movimentos sociais dos imigrantes no Brasil. Podemos dizer, então, que a lei é mais anacrônica ainda por manter algumas exigências (dentre elas, a leitura e a escrita de um trecho da Constituição) que foram estabelecidas há mais de sessenta anos em um Brasil completamente diferente do existente nos dias atuais.

Para se adquirir a nacionalidade brasileira, o estrangeiro precisa passar por algumas etapas burocráticas. Existem algumas diferenças burocráticas entre as leis 818 e 6.815 . Na lei 818 , o percurso até se chegar à aprovação da naturalização é mais detalhado, na medida em que descreve as funções de 
cada uma das instâncias burocráticas que cumprem um papel de destinadorjulgador do requerente à naturalização. Já a lei 6.815 apresenta um percurso menos detalhado e aparentemente mais simples, apesar de exigir praticamente a mesma documentação para comprovar a idoneidade do estrangeiro que deseja se tornar brasileiro. Outra crítica feita pelos movimentos sociais de imigrantes no país se refere, justamente, à excessiva burocratização do processo de naturalização e ao alto custo financeiro para muitos imigrantes.

As leis 818 e 6.815 não apresentam traços claros de intolerância contra o estrangeiro. Mas podemos considerar as exigências da lei para um estrangeiro se tornar brasileiro uma espécie de seleção não explicitada dos "bons estrangeiros" a serem incorporados à sociedade nacional. Merece destaque, a nosso ver, a exigência de se saber ler e escrever em língua portuguesa como um dos critérios para a naturalização, pois ela exclui do processo de naturalização os imigrantes que não são alfabetizados em língua portuguesa. Em resumo, as duas leis constroem a imagem de um imigrante de alto nível (educacional, profissional ou financeiro) que o país aceita para se tornar brasileiro e viver definitivamente no país.

Além disso, no caso específico do Estatuto do Estrangeiro, vimos algumas proibições a certas atividades e, sobretudo, à propriedade de empresas em áreas estratégicas, como a da navegação e a de comunicação. Observamos, ainda no Estatuto do Estrangeiro, que o trabalhador imigrante não pode, em alguns casos, mudar de profissão nem de residência. Em outros casos, ao mudar de residência, ele é obrigado a informar ao Ministério da Justiça, revelando uma preocupação do governo em acompanhar de perto as atividades do imigrante, assim como o seu deslocamento pelo país. Ainda cabe lembrar que o estrangeiro não pode também participar de atividades políticas no país, apesar de o Estatuto do Estrangeiro deixar claro que o imigrante possui os mesmos direitos dos brasileiros. De qualquer forma, cabe ressaltar que o Estatuto do Estrangeiro parece valorizar muito o imigrante com boa formação acadêmica e técnica que pode contribuir para o desenvolvimento econômico nacional.

As proibições acima, ainda vigentes, tem como base a ideia de que 0 estrangeiro pode ser uma ameaça à integridade nacional. Por isso, ele pode ser punido com detenção e, posteriormente, ser expulso do país. Há ainda a 
possibilidade de um estrangeiro perder sua nacionalidade brasileira (no caso de ser naturalizado) no caso em que ele é igualmente considerado uma ameaça ao país. Como dissemos, qualquer estrangeiro naturalizado pode, hipoteticamente, perder a cidadania brasileira a partir de uma acusação feita por um brasileiro nato.

Por fim, vimos a construção da imagem de outro tipo de estrangeiro: o refugiado. Essa lei apresenta um caráter mais "humanista" (em oposição a um traço mais "pragmático" das duas leis anteriores) na medida em que reconhece a situação peculiar do refugiado (como um sujeito que precisa fugir de seu país de origem por se sentir perseguido e ameaçado de morte). Por isso, o Estatuto do Refugiado não apresenta o mesmo nível de exigência presente nas duas outras leis, pois procura facilitar a entrada e o estabelecimento do refugiado no país. Podemos, assim, dizer que o Estatuto do Refugiado é uma lei mais tolerante (e, provavelmente, mais solidária) do que as outras duas porque visivelmente conhece e se preocupa com a situação do refugiado.

Prosseguiremos nosso trabalho examinando como a imagem do imigrante é construída em discursos eminentemente acadêmico-científicos. Observaremos como o imigrante foi estudado em diferentes áreas das ciências humanas ao longo do século XX, tendo como base três artigos publicados em revistas acadêmicas. 


\section{0 discurso 'acadêmico-científico' sobre a imigração e os imigrantes no Brasil: a seleção e a assimilação em foco}

\subsection{Preliminares}

As Ciências Humanas têm, como seu próprio nome diz, o homem como objeto de interesse e estudo. Tudo o que diz respeito ao homem, em sua acepção mais ampla, é passível de ser pensado e analisado pelas Ciências Sociais, pela Filosofia, pela Antropologia, pela Economia, pela Psicologia, pela História e pela Linguística entre outras áreas do conhecimento. Dessa forma, pensa-se no homem em sua dimensão individual ou em sua relação com outros homens e com a natureza, com sua história e com sua linguagem.

Todas essas formas de se pensar e estudar o homem só são possíveis graças à linguagem. Afinal, todos os grandes tratados filosóficos, todas as pesquisas em Ciências Sociais e Antropologia e a nossa própria noção de História existem porque a linguagem organiza e veicula todas essas ideias a respeito do homem.

Por terem como alicerce a linguagem, os textos de todas essas áreas do conhecimento podem se tornar objeto de análise por outros estudos. É justamente esse o propósito deste capítulo, ao tratarmos de textos que lidam com a imigração no Brasil. Apesar de nosso foco não ser exatamente a análise da organização do discurso científico em si mesma, apresentaremos abaixo alguns traços gerais propostos em estudos de outros semioticistas para embasarmos nossa análise, concentrada justamente na construção da imagem do imigrante e da imigração no Brasil.

O discurso científico da chamada Ciências Humanas foi foco de um trabalho coletivo empreendido nos anos 1970 pelo grupo liderado por Greimas na École des Hautes Études en Sciences Sociales, em Paris. O objetivo do grupo foi o de examinar as estruturas invariantes em uma esfera do saber cuja organização ainda não havia sido contemplada (até então as análises eram feitas sobretudo no chamado discurso literário). Realizando essa transposição, do discurso literário para o discurso científico, com a manutenção do mesmo arcabouço teórico, a semiótica foi mostrando o alcance de suas propostas e de suas formas de examinar um texto. Os resultados desse empreendimento 
foram publicados no livro Análise do Discurso em Ciências Sociais ${ }^{106}$ (organizado por Greimas e Landowski).

Os estudos publicados nesse livro foram divididos em três eixos: "Em busca de certezas", "Interrogações sobre o sentido da pesquisa" e "Discursos de interpretação". Em cada um desses três eixos, algumas características gerais podem ser encontradas. Em sua análise sobre o prefácio que George Dumézil escreveu para sua própria obra, Greimas distingue três discursos: 0 cognitivo, o objetivo e o referencial. $O$ discurso cognitivo pode ser compreendido como o percurso de aquisição do /saber/; o discurso objetivo apresenta os objetos do saber e, principalmente, as manipulações que esse objeto sofre ${ }^{107}$; e o discurso referencial é caracterizado principalmente como o discurso de autoridade por citar outros discursos (Greimas, 1986: 45-48).

Veremos, em nossas análises, algumas dessas operações discursivas propostas por Greimas. Por exemplo, o percurso de aquisição do saber pode ser compreendido a partir das propostas para uma melhor política imigratória brasileira. Em outras palavras, as propostas referentes à política imigratória surgem como uma doação de saber para o enunciatário. Já o discurso objetivo aparece quando os textos tratam do tema "racial", pois dificilmente surgem traços subjetivos a respeito da avaliação "racial" de determinados grupos imigrantes (o que ocorre é exatamente o contrário: a noção de raça aparece quase que por si só, como se fosse um fato irrefutável nos discursos que analisaremos). Por fim, o discurso referencial aparece por meio da menção a outros discursos e autores para dar o respaldo necessário às ideias desenvolvidas e defendidas por cada um dos enunciadores cujos textos serão analisados.

Além do mais, como toda teoria se transforma (com o surgimento e o desaparecimento de conceitos), usaremos também conceitos mais recentes da teoria semiótica, em especial as noções de interação (já apresentadas no capítulo teórico) e a formação dos valores no nível tensivo. Devemos, ainda, dizer que o uso de conceitos advindos da chamada semiótica tensiva -

\footnotetext{
106 A tradução brasileira suprimiu o termo "Introdução" do título original.

${ }^{107}$ Greimas descreve três manipulações presentes no texto de Dumézil: o fazer taxionômico (que consiste em "consolidar os objetos do saber por operações de inclusão") (Greimas, 1986: 46); o fazer programático (que organiza sintagmaticamente as operações cognitivas); e o fazer comparativo (que estabelece as relações entre os objetos do saber do discurso) (Greimas, 1986: 46).
} 
amplamente aplicados na análise da dimensão estésica e sensível dos textos tem como inspiração, em nosso trabalho, o estudo de José Luiz Fiorin, intitulado "A construção da identidade nacional brasileira" (2009). Baseado nas propostas de Fontanille e Zilberberg (2001), Fiorin mostra como a identidade de uma cultura, de uma sociedade ou de um país é construída por meio de dois princípios: a triagem e a mistura. O primeiro privilegia o exclusivo, construído a partir da exclusão de elementos estranhos a essa identidade (o que implica, igualmente, em uma circulação mais restrita dos valores e elementos que definem essa identidade), enquanto o segundo se baseia na relação entre o igual e o desigual, na qual os valores circulam em um espaço mais amplo (Fiorin, 2009: 117-118).

Neste capítulo, examinaremos os seguintes textos, nesta ordem: a) "A Imigração", de Geraldo de Menezes Côrtes (publicado na Revista de Imigração e Colonização em 1947); b) "O papel das associações juvenis na aculturação dos japoneses", de Ruth Correa Leite Cardoso (publicado na Revista de Antropologia em 1959); c) "Algumas considerações sobre a imigração no Brasil”, de P. Pereira dos Reis (publicado na revista Sociologia em 1961).

Os textos de Côrtes e de Reis apresentam os seguintes traços gerais: propostas de reformulação da política imigratória, incluindo critérios de seleção e de assimilação; construção positiva da imagem dos imigrantes de origem europeia em detrimento dos imigrantes de origem asiática e dos migrantes nacionais; estabelecimento ou não de uma imagem positiva da sociedade brasileira (ou de parte dela); presença de isotopias econômica e cultural. Veremos nas análises as diferenças existentes em cada texto, assim como os elementos em comum entre eles.

O estudo de Ruth Cardoso examina o processo de aculturação, ocorrido nas associações juvenis, de filhos de imigrantes japoneses. Seu trabalho mostra as tensões na comunidade japonesa causadas pela mudança de padrões comportamentais dos jovens filhos de japoneses no Brasil.

Antes de iniciarmos as análises, é preciso ainda levantar alguns traços gerais dos textos que constituem nosso corpus. Partimos do princípio, arbitrário por definição, de que todos os textos analisados podem ser incluídos no discurso a que chamamos "acadêmico". Isso se deve basicamente a dois motivos, um discursivo e outro extradiscursivo: a) os textos foram publicados 
em revistas de tema específico (sobre a imigração ou da área de sociologia, por exemplo); b) estão presentes nos textos elementos comuns ao discurso acadêmico (como o conhecemos atualmente), como citação de outros discursos e de outros autores, confirmação ou refutação de ideias, etc.

Mesmo dotados de um efeito de sentido de objetividade, discursos "científicos" podem trazer pontos de vista preconceituosos por meio dos valores que eles expressam e pelos julgamentos que ultrapassam a simples descrição "empírica" de fenômenos sociais. Nossa análise visa justamente a examinar a constituição desses valores que, de certa forma, orientam as sanções (positivas ou negativas) sobre $0 /$ fazer/ e o /ser/ dos imigrantes e sobre 0 processo imigratório geral. Como vimos no terceiro capítulo, uma das maneiras de se entender a organização do discurso intolerante e preconceituoso é, justamente, por meio da narrativa de sanção.

Por fim, precisamos também apontar para um primeiro problema que surge neste capitulo. Trata-se da questão dos conceitos presentes em dois universos epistemológicos distintos. De um lado, conceitos como aculturação, assimilação, exclusão, segregação e mestiçagem estão presentes há algum tempo nas chamadas Ciências Sociais. Por outro lado, alguns desses mesmos conceitos foram retomados e integrados à teoria semiótica nos trabalhos de Landowski (assimilação, exclusão, segregação) e Zilberberg (mestiçagem). Como já foi feita uma explanação desses conceitos na perspectiva adotada pela semiótica (no capítulo teórico desta tese), decidimos por fazer os esclarecimentos sobre os conceitos utilizados nas Ciências Sociais no próprio corpo da análise, quando considerarmos pertinente.

\subsection{Centralização e totalização em um discurso sobre a imigração no Brasil pós-guerra}

\section{Introdução}

Como vimos no primeiro capítulo deste trabalho, o final da Segunda Guerra Mundial retira de milhares de pessoas seus lares, seus trabalhos, seus parentes, seus sonhos e seus planejamentos, em resumo, suas vidas cotidianas. Desse modo, um contingente humano fica a mercê de auxílios 
vindos de outros países ou de órgãos internacionais criados com o propósito de ajudar esses indivíduos (que são mais conhecidos como os deslocados de guerra). A saída de seu país, devastado pela guerra, é uma das possibilidades colocadas a esses indivíduos, que podem então recomeçar suas vidas em outro lugar.

Após a interrupção do fluxo migratório por causa da Segunda Guerra Mundial, os países do continente americano voltam a se interessar pelos imigrantes, principalmente os europeus. Especificamente no caso brasileiro, são retomadas as discussões sobre o processo imigratório para se estabelecer o melhor modo de contar com a presença dos possíveis imigrantes vindos dos países envolvidos na Segunda Guerra Mundial.

Os discursos a respeito da melhor forma de se conduzir o processo imigratório no Brasil pós-guerra mantêm algumas características dos discursos que surgiram no início da imigração no país, ainda no século XIX. Assim, é possível observar duas formas de relação interdiscursiva nessas discussões: uma polêmica e outra contratual, ambas baseadas, obviamente, na figura do imigrante. Assim, há discursos favoráveis à imigração irrestrita, à imigração controlada e à proibição da imigração. $O$ discurso mais frequente é o da imigração controlada, cuja característica geral é a de ser um discurso voltado para propostas de seleção daquele que é considerado o melhor imigrante para o país. No estabelecimento desses critérios de seleção, toda uma outra gama de possíveis imigrantes é deixada de lado, por meio de escolhas baseadas em traços culturais, biológicos, econômicos ou sociais.

Além da seleção para entrada dos imigrantes, ainda são discutidas formas de integração do imigrante ao "corpo social nacional". Tanto a seleção como a assimilação visam, de um modo geral, à preservação de uma suposta unidade nacional, representada por conceitos abstratos como identidade nacional, caráter nacional, cultura nacional, etc. Como duas faces da mesma moeda, a seleção e a assimilação de imigrantes caminham, frequentemente, juntas nos discursos que tratam da imigração nesse período, ainda como reflexo das discussões sobre esse tema nas décadas iniciais do século XX.

Outro aspecto frequente nos debates a respeito da imigração no Brasil está na associação, quase direta, da presença do imigrante a um maior desenvolvimento econômico e cultural da nação. Assim, o imigrante é 
concebido também como um elemento de melhoramento das condições materiais e simbólicas da nação brasileira, cujas orientações para o pleno desenvolvimento são discutidas pela chamada "elite nacional".

Assim, uma série de políticos, militares e intelectuais se envolve nos debates a respeito de reformas ou de manutenção da política imigratória brasileira, cada qual contribuindo com seu ponto de vista e seu conhecimento. Dentre essas pessoas, Geraldo de Menezes Côrtes procura dar sua contribuição ao debate por meio do texto intitulado "A Imigração", publicado na Revista de Imigração e Colonização em 1947. Esse texto se insere, por suas propostas, no campo da imigração controlada, caracterizada pela seleção criteriosa e rígida de grupos imigratórios para o Brasil.

O texto de Menezes Côrtes está organizado e subdividido em quatro seções: 1) "Como encarar a imigração atualmente" (que contém ainda mais cinco subdivisões: a) Suas causas; b) O quadro atual nos países de imigração; c) Situação das migrações internas, como aproveitar suas tendências e possibilidades; d) Diversas condições internas existentes e a considerar; e) Conclusões para a politica imigratória a adotar); 2) "Necessidades a que a estrutura administrativa para a imigração deve atender"; 3) "Bases dos planejamentos que devem ser montados"; e 4) "Projeto de lei" (Côrtes, 1947: 5).

Além das propostas apresentadas por Côrtes para a seleção e a assimilação do imigrante no Brasil, veremos também como seu projeto para o processo imigratório brasileiro envolve uma vontade totalizante. Em outras palavras, seu discurso se caracteriza por um /querer-fazer-dever-fazer/ que pretende englobar todas as etapas da imigração, nos menores detalhes possíveis. Uma das consequências dessa tentativa de totalização está presente na ideia de criação de um órgão central (chamado de Departamento Nacional de Imigração e Assimilação) que coordenaria todas as ações da imigração no Brasil, sendo subordinado apenas e diretamente à Presidência da República.

Por meio do que chamamos de "vontade totalizante" de suas propostas, podemos perceber a importância dada por Côrtes ao processo imigratório no Brasil. Ele considera a imigração um processo fundamental para o desenvolvimento econômico nacional e para a melhoria cultural (e, 
implicitamente, racial) da sociedade brasileira. Por isso, quanto mais centralizada e detalhada for a proposta do processo imigratório, maiores são as chances de sucesso e de benefícios para o país, pois seriam menores as possibilidades de falhas.

Essa organização totalizadora e centralizadora se baseia, do ponto de vista do enunciador, na defesa dos valores nacionais (unitários e homogêneos, segundo seu discurso) e em uma melhoria da sociedade brasileira. Por ser um discurso que deseja controlar todas as possibilidades do processo imigratório, prevendo-as para evitar falhas, as propostas de Geraldo de Menezes Côrtes estabelecem um recorte para definir qual o melhor tipo de imigrante para 0 país. Veremos como algumas características valorizadas nos imigrantes selecionados promovem, consequentemente, a exclusão de todo um contingente de possíveis imigrantes, revelando, assim, uma postura preconceituosa, mesmo que difusa em seu texto. O texto de Geraldo de Menezes Côrtes pode ser caracterizado, assim, como um conjunto de propostas para um novo processo imigratório em discussão no Brasil.

Iniciaremos a análise por um tópico frequente nos discursos sobre a imigração no Brasil: tal como planejada e executada em seu tempo, o processo imigratório apresenta uma série de problemas. Tendo problemas, esse processo necessita de uma revisão de seus conceitos e de suas práticas para ter seus problemas resolvidos mediante novas propostas. São justamente os antigos problemas e as novas propostas de Côrtes que serão analisados a seguir.

\section{Os problemas nacionais e a imigração como solução}

O discurso de Côrtes procura indicar problemas e insuficiências no modo como o processo imigratório está sendo conduzido em seu tempo. Ao mesmo tempo, ele aponta para problemas próprios ao Brasil, cuja solução passa também pela entrada e instalação dos imigrantes. Consequentemente, como já dissemos, os problemas detectados pelo enunciador são o ponto de partida para a apresentação de suas propostas para a política imigratória.

Além do mais, logo no início do texto, fica explicitada uma das motivações do enunciador para apresentar suas propostas. $O$ fato de ele ser 
nomeado membro do Conselho de Imigração e Colonização, pelo então presidente Eurico Gaspar Dutra, expõe, em alguma medida, sua motivação e sua autoridade para tratar do assunto "imigração", reforçadas ainda pelo conhecimento autodeclarado sobre o tema:

\begin{abstract}
Este trabalho visa sintetizar as ideias que tenho a respeito do problema e das bases para sua solução, sendo um modesto subsídio, à disposição do Governo, o qual se vê vivamente empenhado em solucioná-lo, quer reestruturando a administração correspondente quer traçando a política imigratória a adotar (Côrtes, 1947: 5).
\end{abstract}

Dessa forma, o texto de Geraldo de Menezes Côrtes se configura como uma organização programática para a política imigratória brasileira, com reformas e revisões de princípios em um momento de renovação política do Brasil que acaba de sair de uma ditadura (de Getúlio Vargas) e da Segunda Guerra Mundial.

O texto parte do princípio de que há problemas no processo imigratório nacional, assim como problemas nacionais que podem ser resolvidos pela presença do imigrante. Se há problemas na política imigratória, em parte por culpa dos governos anteriores (mesmo que ele não mencione isso claramente), o texto procura sugerir soluções a esses problemas, tanto em seus aspectos administrativos e burocráticos como em relação à infraestrutura que pode ser instalada para um melhor acolhimento do imigrante no país em vista de sua assimilação. $O$ enunciador crê, assim, que pode apresentar as propostas a serem adotadas pelo governo brasileiro para trazer os melhores imigrantes para o país. Por essa razão, seu texto se configura, em sua totalidade, como uma manipulação cujos destinatários são o governo brasileiro e os leitores da revista.

Um primeiro problema do país, apontado pelo texto, é o dos grandes espaços demográficos vazios. Em outras palavras, o Brasil apresenta um déficit populacional em determinadas regiões. Pela proposta de Côrtes, o imigrante pode ser utilizado para preenchê-los. Ocupar os espaços vazios significa, assim, encaminhar imigrantes para cultivar as terras, que estão sendo esvaziadas pelas migrações internas em direção às grandes cidades: 
No presente momento um dos aspectos que mais preocupa a administração pública e os estudiosos do assunto e que condicionará, por certo, a política imigratória é o fraco índice demográfico das zonas rurais num contraste flagrante com o crescimento das populações urbanas. Situação que aconselha olhar com o maior interesse para a imigração que proporcione possibilidades de colonização agrícola (Côrtes, 1947: 7).

\begin{abstract}
Respaldado, assim, pela conformidade de preocupações dele, da "administração pública" e dos "estudiosos", o enunciador encontra uma justificativa para tentar resolver o que ele considera um dos mais urgentes problemas brasileiros a ser resolvido: o fraco índice demográfico em certas regiões do Brasil. A falta de material humano para o trabalho agrícola é uma das consequências desse problema. Por isso, se há uma falta no programa narrativo brasileiro, o imigrante pode se tornar o sujeito competente para eliminá-la:
\end{abstract}

Eis aí o problema mais urgente, embora não seja o mais importante, porque fortuito, que está preocupando o Governo e a exigir um plano montado para chegar-se às soluções práticas e interessantes que focalizaremos mais adiante ao tratarmos do caso geral (Côrtes, 1947: 7).

Além desse primeiro problema (espaços vazios no interior do país), o texto de Côrtes mostra outro para o qual o imigrante pode ser uma solução viável. A do desenvolvimento econômico nacional que, naquele momento, não apresenta a velocidade de desenvolvimento almejada pelo enunciador:

Quer em relação ao elemento nacional, quer em relação ao estrangeiro, tratase de aproveitar esse desejo humano e natural de 'ser mais feliz' para, com inteligência, concorrer no sentido de acelerar nosso desenvolvimento econômico (Côrtes, 1947: 5-6).

Como se pode observar no trecho acima, o programa narrativo de base do discurso de Cortez é o do "desenvolvimento econômico". E nesse programa narrativo, o imigrante e o migrante nacional ${ }^{108}$ são os sujeitos responsáveis por produzir esse aumento do desenvolvimento econômico nacional. A preocupação do enunciador com os espaços vazios foca a retomada do desenvolvimento econômico agrícola. Mas seu projeto não se resume a isso. Ele engloba, como veremos adiante, igualmente o imigrante para o trabalho na

\footnotetext{
${ }^{108}$ Veremos, adiante, o paralelismo existente entre o migrante nacional e o imigrante no discurso de Côrtes.
} 
indústria. Sendo o imigrante, então, um sujeito que vai reparar uma falta existente no programa narrativo brasileiro, é necessário antes selecionar esse sujeito para que sua ação seja bem feita e não apresente problemas.

Veremos, abaixo, como são construídos os princípios para a seleção de imigrantes no discurso de Menezes Côrtes, decorrentes dos valores defendidos pelo enunciador.

\section{Como selecionar o imigrante: a triagem e suas consequências}

Toda discussão acerca da política imigratória envolve algum tipo de seleção porque sempre se pretende o melhor para o país que acolhe os imigrantes. A diferença entre os discursos envolvidos nessa discussão está nos valores utilizados para desenvolver os critérios para a seleção de imigrantes.

No nível narrativo do discurso de Côrtes, dois programas de uso existem para propiciar uma plena realização do programa narrativo de base que identificamos como sendo o do desenvolvimento econômico do Brasil. $O$ primeiro programa de uso é o da triagem, que pode ser dividido em duas operações distintas de exclusão. O segundo programa é o da mistura, que é convertida no tema da assimilação dos imigrantes para que se melhore a própria sociedade brasileira, foco da próxima seção desta análise.

Esta seção será dedicada a observar como a proposta de seleção é organizada em três etapas no discurso de Menezes Côrtes. Adiantamos que há uma triagem átona que é responsável pela separação dos imigrantes em dois grupos distintos. Em seguida, uma triagem tônica que implica a exclusão de um grupo em proveito de outro. Há, por fim, uma última triagem, novamente átona, que é projetada sobre uma das partes geradas pela triagem tônica, que separa indivíduos de um mesmo grupo social ou de uma mesma origem nacional, produzindo duas categorias distintas: os imigrantes aptos a entrar no país e os imigrante inapropriados para o Brasil. As três triagens têm em comum realçar as características negativas dos imigrantes que não podem ser aceitos no país e as melhores qualidades do imigrante que deve entrar no país.

Em suas propostas para o processo imigratório brasileiro, Côrtes considera inicialmente dois tipos de motivações relacionadas às "correntes migratórias": a "material" e a "sentimental". A primeira se caracteriza por 
envolver "a corrida ao melhor salário, às melhores condições de vida onde se possam encontrar fatores atrativos como os de bom clima, salubridade, alimentação fácil, habitação etc.", enquanto a segunda é marcada pelas "consequências de conflitos sociais, quer de ordem religiosa, quer de ordem política" (Cortez, 1947: 5).

No texto, a motivação "material" é mais importante do que a "sentimental" porque aquela sempre existiu e sempre existirá em qualquer processo imigratório, uma vez que o desejo de uma vida melhor, que impulsiona uma pessoa a buscar sua realização, mesmo em outro país, é um traço inerente ao ser humano, segundo Côrtes. Já a motivação "sentimental" decorre, segundo o texto, de situações mais raras, como as grandes revoluções e os conflitos, que criam um ambiente insuportável que leva uma pessoa a sair de seu país de origem.

Para o enunciador, uma correta política imigratória brasileira deve se preocupar, principalmente, com os elementos do primeiro tipo. Em certa medida, o enunciador começa a delinear seus próprios valores, uma vez que ele instaura uma visão mais pragmática ${ }^{109}$ do que humanista em suas considerações sobre a imigração. Ele coloca em segundo plano o interesse por possíveis imigrantes que fogem de seu país de origem por conta dos horrores causados pela guerra ou por causa das perseguições decorrentes de revoluções. Podemos dizer que, para o enunciador, o imigrante a ser privilegiado é aquele com condições plenas para trabalhar no país, característica não completamente garantida nos imigrantes que saem de seu país por causa das perseguições.

Dessa forma, o enunciador vislumbra a possibilidade de atrair imigrantes com vontade de "vencer na vida", ou seja, de conquistar uma vida melhor por meio do trabalho. Essa vontade é a qualidade necessária para ser um bom trabalhador, esforçado, disciplinado e focado em seus objetivos. Em outras palavras, o país necessita de imigrantes dotados da modalidade do /quererfazer/. Consequentemente, possuir uma quantidade considerável de trabalhadores com essa característica pode conduzir o país a um aceleramento da economia, como deseja o enunciador.

\footnotetext{
${ }^{109}$ Veremos abaixo como o enunciador constrói a imagem definitiva do imigrante desejável para o Brasil, baseado justamente em sua visão pragmática do processo imigratório.
} 
Essa questão do movimento humano motivado pelo desejo de encontrar melhores condições de vida em outro lugar se aplica, no texto, tanto aos estrangeiros como aos brasileiros que residem em regiões precárias (como vimos no trecho citado na seção anterior, referente à aceleração do desenvolvimento econômico nacional). Esse desejo de uma vida melhor, presente em qualquer ser humano, deve ser explorado pela política imigratória brasileira para daí poder usar essa característica em proveito do país.

Essa primeira triagem sobre o imigrante, enquanto uma totalidade dotada de sentido, separa o imigrante mais desejável (dotado de "força de vontade para o trabalho") do menos desejável (o que vem para o Brasil por causa das condições precárias do seu país, devastado por uma guerra ou por uma revolução). $O$ discurso mostra que esse último tipo de imigrante pode ser aceito, mas não deve ser prioridade para a política imigratória, pois fica implícita a ideia de que a vontade de trabalhar não pode ser garantida como no primeiro tipo de imigrante.

A segunda forma de triagem promovida pelo discurso de Geraldo de Menezes Côrtes ocorre entre imigrantes europeus, de um lado, e imigrantes asiáticos, do outro. A triagem, que realiza a separação em dois grupos distintos, faz com que o grupo asiático seja excluído das discussões a respeito da imigração no Brasil. Produz-se, por meio da triagem tônica, uma separação categórica do universo semântico "imigrantes", tomados, até então, como uma totalidade dotada de sentido. No trecho abaixo, podemos observar a justificativa para essa exclusão:

Trataremos somente dos Países Europeus visto que os Asiáticos, por condições raciais inassimiláveis, não devem entrar em nossas cogitações de aproveitamento (Côrtes, 1947: 6).

Em uma perspectiva semiótica, vemos, no fragmento acima, que a triagem tônica produz a exclusão dos imigrantes de origem asiática. Ocorre aqui uma sanção negativa sobre o/ser/ dos possíveis imigrantes que têm essa origem. A justificativa para essa sanção é a de que os imigrantes asiáticos não têm condições de cumprir um contrato baseado na "raça", ou seja, eles não conseguem se integrar completamente à sociedade brasileira, pois a diferença racial da qual eles são portadores os impede de serem assimilados, segundo o 
texto. Por isso, fica implícita a ideia de que a sociedade brasileira ${ }^{110}$ é ou deve ser constituída por indivíduos brancos em um momento histórico em que a imigração japonesa já é mais do que uma realidade no país. Os imigrantes de origem asiática são excluídos, assim, logo no começo do percurso narrativo de uso no discurso de Côrtes.

A negação que incide sobre os imigrantes de origem asiática, no trecho acima ("não devem entrar em nossas cogitações de aproveitamento"), merece ainda alguns comentários. Zilberberg, em trabalho recentemente publicado sobre a "Condição da negação" (2010: 02), constrói, a partir das noções de subcontrário e sobrecontrário, um quadro paradigmático com as diferentes intensidades das formas de afirmação e negação ${ }^{111}$ :

\begin{tabular}{|c|c|c|}
\hline & Sobrecontrário tônico & Subcontrário átono \\
& $\downarrow$ & $\downarrow$ \\
\hline Afirmação $\rightarrow$ & Totalmente de acordo & Sim \\
\hline Negação $\rightarrow$ & De jeito nenhum & Não \\
\hline
\end{tabular}

A presença da modalidade deôntica no trecho assim nos leva a pensar que não se trata apenas de uma simples negação (átona), mas sim de uma forma tônica de negação ("de jeito nenhum") por envolver a impossibilidade (/não-poder-ser/) de se contar com os imigrantes asiáticos como parte do processo imigratório no Brasil. Essa negação categórica sobre os imigrantes asiáticos é a segunda operação para a construção da figura do imigrante ideal para o país.

O texto passa a tratar somente dos imigrantes de origem europeia. Pela sua concepção, os países devastados pela guerra na Europa podem fornecer bons imigrantes para o país. Mas para isso acontecer, é preciso ainda realizar

${ }^{110}$ Essa é a única passagem do texto que menciona os asiáticos. Por isso, não é possível afirmar ainda que a concepção da sociedade brasileira construída por Côrtes é exatamente a que dissemos, uma vez que seu texto também não trata explicitamente da constituição racial da sociedade nacional.

${ }^{111}$ Transcrevemos, abaixo, o quadro original:

\begin{tabular}{|c|c|c|}
\hline & Sur-contraire tonique & Sous-contraire atone \\
$\downarrow$ & Oui \\
\hline Affirmation $\rightarrow$ & Tout à fait & Non \\
\hline Negation $\rightarrow$ & Pas du tout & . \\
\hline
\end{tabular}


outra triagem para separar os bons trabalhadores dos indivíduos inapropriados para o Brasil.

\begin{abstract}
Devido às situações políticas nos Estados que se viram arrastados na convulsão da Guerra, particularmente os que sofreram e sofrem a interferência direta da Rússia Soviética, depois do domínio alemão, há grande parte de população deslocada dos Estados natais e aos cuidados das autoridades norte-americanas e inglesas de ocupação, reunidos em campos de concentração ou de trabalho, onde o índice cultural e o valor econômico maior ou menor dessa gente podem ser apreciados pelo trabalho produtivo que desenvolvem, pelos encargos que oneram as autoridades de ocupação, pelo índice de valor sanitário e de vigor físico dessa massa humana, cujo valor tanto se discute e que são os 'Displaced Persons', desajustados ou deslocados de guerra. Pelas informações já colhidas: há entre eles elementos perturbadores do equilíbrio social; há 'desajustados do trabalho', gente que perdeu o hábito de labutar; há os doentes mentais ou d'alma, aparentemente sãos, mas minados pelas nevroses de guerra, pelos estados psíquicos da 'angústia humana' de que tanto nos fala Maurice de Fleury e a cujas funestas consequências não se poderiam furtar os homens envolvidos no furor dos mais terríveis dramas íntimos que esta Guerra deve ter proporcionado; há judeus que se acham obsecados [sic] pelos problemas da Palestina e cujo valor econômico-social é de forma a não se recomendarem à nossa corrente imigratória (não se trata do odioso preconceito racial dos nazistas mas da defesa dos nossos interesses econômicos, conceito admitido e defendido no Congresso de Montreal pelas nações anglo-saxônicas em relação a asiáticos e mestiços) (Côrtes, 1947: 6) ${ }^{112}$.
\end{abstract}

Uma triagem átona é projetada sobre os sujeitos que se encontram fora de seus respectivos países de origem (os "deslocados de guerra") para separar os imigrantes desejáveis ("pelo trabalho produtivo", "pelo índice de valor sanitário e de vigor físico") e os imigrantes indesejáveis ("elementos perturbadores do equilíbrio social", "desajustados do trabalho" etc.). Entendemos que se trata de uma triagem átona, pois a dimensão passional está menos presente do que na exclusão categórica feita sobre os imigrantes de origem asiática.

O discurso de Côrtes segrega, assim, outros sujeitos do processo imigratório brasileiro. Sujeitos modalizados pelo /não-poder-ser/ ("doentes mentais ou d'alma") e pelo /não-querer-fazer/ ("gente que perdeu o hábito de labutar") não devem ser aceitos no país porque não têm, segundo Côrtes, condições de ajudar o Brasil a se desenvolver econômica e culturalmente.

Ainda no trecho acima, a triagem átona é aplicada também aos judeus, que estão mais preocupados em discutir a fundação do Estado de Israel do que

\footnotetext{
${ }^{112}$ Lamentavelmente, não conseguimos obter nenhuma informação histórica sobre o referido Congresso de Montreal.
} 
em procurar outros países para se estabelecer, ou seja, os judeus não estão interessados em emigrar (/não-querer-ser/ imigrantes) e desejam fundar seu próprio país, segundo o enunciador. Mesmo assim, observamos uma restrição do enunciador a esse grupo no seguinte trecho: "cujo valor econômico-social é de forma a não se recomendarem à nossa corrente imigratória". Mas sua restrição é minimizada pela justificativa de que não se trata de racismo (tal como a dos nazistas), mas sim de colocar os interesses econômicos do Brasil em primeiro lugar, postura respaldada pelo Congresso de Montreal. De certa forma, o discurso de Geraldo de Menezes Côrtes confirma essa ressalva, uma vez que veremos a isotopia econômica predominar em suas propostas para a imigração no Brasil. A triagem átona que acabamos de mostrar é o terceiro movimento para a construção da figura do imigrante ideal para o país.

Além de explicitar as características dos imigrantes indesejados, sujeitos que devem ser impedidos de entrar no país, a triagem átona é responsável também por mostrar quais as características do bom imigrante visado pelo Brasil. O trecho abaixo mostra algumas dessas características, que são complementadas por outro fragmento que será analisado logo em seguida:

\footnotetext{
Mas também informam que há gente boa, de valor econômico apreciável, com boa saúde e vigor físico, estado d'alma aproveitável na nossa comunidade e cujos conflitos sentimentais de ordem religiosa ou política incompatibilizam-na com a vida na pátria de origem. Se assim é, que venha essa gente, mas só essa, cuidadosamente selecionada (Côrtes, 1947: 6-7).
}

Basicamente, o bom imigrante é aquele que reúne as características para o bom desenvolvimento do trabalho ("valor econômico aproveitável", "boa saúde" e "vigor físico") e que não apresenta incompatibilidade com certos valores defendidos pelo enunciador, como a religião e a política (mesmo que esses últimos valores sejam o motivo para a saída de seu país de origem). Dessa maneira, há também uma preocupação do enunciador em permitir somente a entrada de indivíduos que possam ser úteis à sociedade brasileira, em diferentes aspectos. Essa concepção utilitarista do imigrante não deixa de estar, assim, associada ao seu ponto de vista pragmático sobre a imigração, conforme mencionamos mais acima.

Além desses critérios, até certo ponto generalistas, vemos abaixo itens mais detalhados para serem usados na seleção do imigrante. O tema "raça", 
que havia aparecido no trecho referente aos asiáticos, reaparece nesse trecho junto a outros critérios, como podemos ver abaixo:

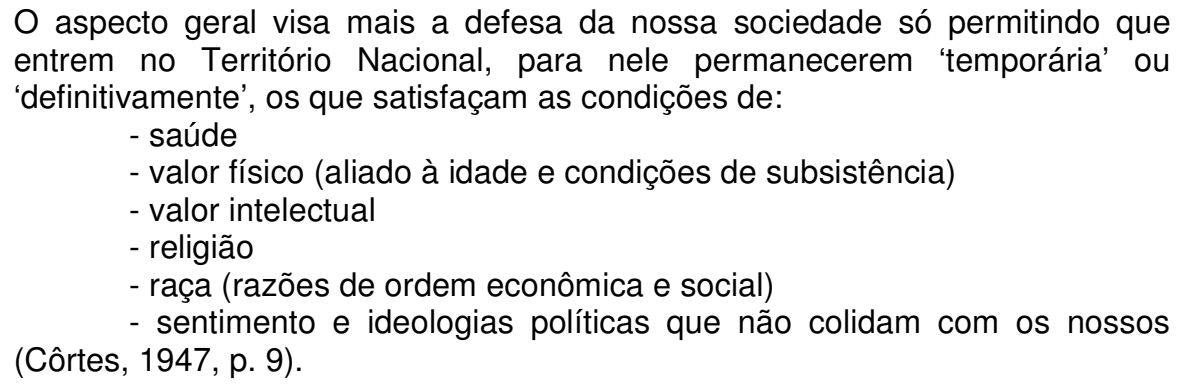

A imagem do imigrante desejável para o país começa finalmente a ser definida. Ela é baseada na capacidade do sujeito-imigrante europeu para o /poder-fazer/ ("saúde" e "valor físico"); o /saber-fazer/ ("valor intelectual"); e também as modalidades do seu /ser/ ("religião", "raça" e "ideologia" idêntica à supostamente praticada no país). Essas modalidades são convertidas nos seguintes temas: biológico (saúde, valor físico), cognitivo (intelectual), cultural (religião), racial (raça) e político (ideologias). Em especial, destacamos o tema "raça", que apresenta a justificativa econômica e social para estar presente dentre os critérios de seleção. Fica, assim, mais claro que esse último critério serve para selecionar somente imigrantes brancos europeus que possuem a capacidade desejável para o trabalho e para a manutenção da ordem social e da unidade social nacional ${ }^{113}$.

Como parte de seu projeto, o enunciador menciona ainda as características ideais de cada imigrante nas três esferas econômicas (agricultura, indústria e comércio). Essas características são apresentadas detalhadamente com o intuito, novamente, de regular o bom funcionamento da seleção do imigrante no Brasil em sua dimensão econômica:

O aspecto particular visa enquadrar o estrangeiro nos Planos em execução.
Tais planos evoluem naturalmente, mas hoje devem enquadrar-se dentro da
seguinte política:
10. - Para fins agrícolas - Só interessa o elemento estrangeiro que possa vir
trabalhar por conta própria e com a perspectiva de tornar-se proprietário:
melhor forma de fixá-lo à terra e concorrer para assimilação mais rápida.
Dar ao elemento nacional deslocado idêntica oportunidade, só se admitindo o
aproveitamento das migrações internas dirigidas para colocação da mão de ${ }^{113}$ Lembramos, ainda, que a imigração japonesa já era mais do que uma realidade no país, a despeito das
inúmeras discussões sobre as vantagens e as desvantagens desse grupo no país. 
obra simples, quando se tratar de elementos que não tenham capacidade para enfrentar o trabalho por conta própria.

2o. - Para fins industriais - Só interessa o estrangeiro que já possua comprovada especialidade ou aptidão técnica.

A mão de obra, ainda não preparada ou especializada, deve ser obtida de preferência com elemento brasileiro local e, no caso de impossibilidade, com as migrações internas dirigidas.

3‥ - Para a exploração comercial - no sentido restrito do termo, deve ser vedada a vinda de estrangeiros, inclusive dos portugueses (Côrtes, 1947: 9).

$\mathrm{Na}$ agricultura, o imigrante que interessa é o do /poder-fazer/. Para complementar o seu /poder-fazer/, está ainda previsto no discurso que esse imigrante deve ter também a modalidade do /querer-ser/ proprietário. A possibilidade de tornar o imigrante proprietário de terras no Brasil se deve, segundo o texto, ao fato de assim se aumentar as chances de o imigrante se fixar no país.

Tornar-se proprietário de terras também é algo admitido ao migrante nacional ${ }^{114}$, com a diferença de que é possível também, nesse discurso, utilizar o migrante como mão de obra barata para o trabalho no campo (quando não tiver a organização modal necessária para ser proprietário). Dessa forma, o enunciador mostra que o migrante pode ocupar uma posição inferior à do imigrante, cumprindo o papel de adjuvante (mão-de-obra barata) para o fazer do imigrante.

No caso da indústria, o destaque fica para a especialidade do imigrante em uma determinada atividade na indústria nacional. Em outras palavras, o imigrante para a indústria se caracteriza, principalmente, pelo /saber-fazer/. Ao migrante interno, fica reservada a possibilidade de não especialização da mão de obra, quando não houver trabalhadores suficientes em uma determinada localidade onde o parque industrial está instalado. Da mesma forma como ocorre com a discussão sobre a agricultura, o migrante nacional pode se tornar um adjuvante do imigrante, tematizado, nesse caso, como "mão de obra não especializada".

A área do comércio chama a atenção pelo fato de estar completamente interditada ao imigrante no discurso de Geraldo de Menezes Côrtes. Essa proibição se estende inclusive ao português, grupo imigrante que sempre teve algum tipo de distinção nas considerações a respeito da imigração ou mesmo

\footnotetext{
${ }^{114}$ Esse paralelismo entre imigrante e migrante na indústria e na agricultura ficará mais claro na seção referente à assimilação do imigrante.
} 
nas leis imigratórias do país ${ }^{115}$. Enquanto se espera imigrantes para o trabalho na agricultura e na indústria, a atividade comercial é completamente proibida na proposta de Côrtes.

Fecha-se, assim, a construção do imigrante idealizado pelo discurso de Côrtes. Apenas os imigrantes que gozam de boa saúde, possuem boa formação educacional e que sejam brancos e cristãos podem ser aceitos pelo governo brasileiro para trabalhar na agricultura e na indústria nacionais. Para se chegar a essa imagem, o discurso de Reis, inicialmente, promove a exclusão dos demais possíveis imigrantes (asiáticos e os europeus que não possuem as características exigidas), que permanecem fora das considerações do processo imigratório brasileiro.

Esquematicamente, podemos representar as operações de triagem, que incidem sobre a totalidade a qual chamamos "imigrantes", da seguinte maneira:

115 O texto de Côrtes não chega a desenvolver uma explicação para essa proibição do imigrante à atividade comercial. Possivelmente, essa proibição esteja ligada à ideia de que o imigrante desejável deva apenas produzir, tanto na indústria como na agricultura, mas não explorar e comercializar produtos. 


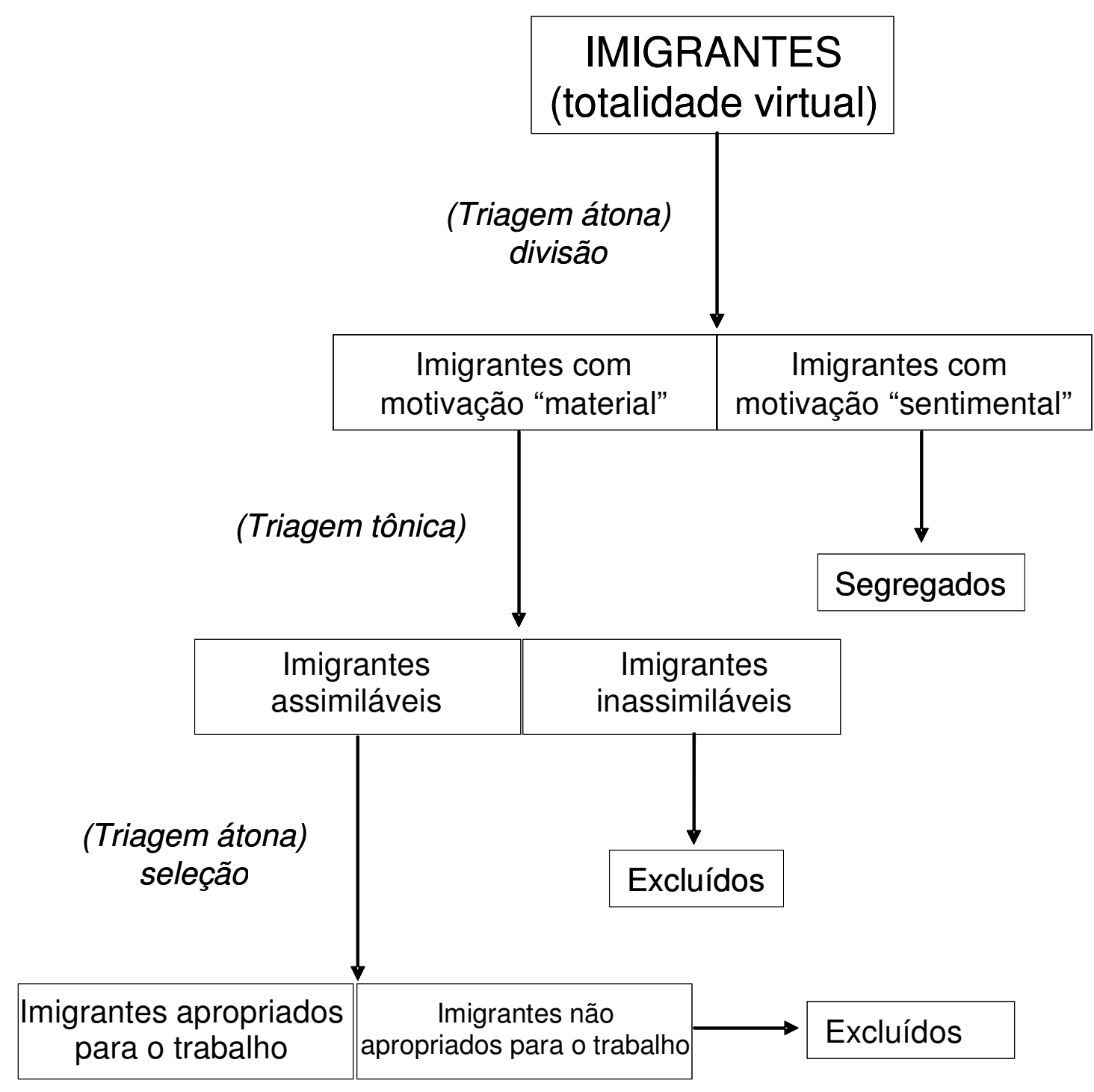

Podemos, ainda, para facilitar a compreensão e não escapar do nosso quadro teórico, representar em um esquema tensivo as duas operações de triagem mencionadas no começo desta seção: 


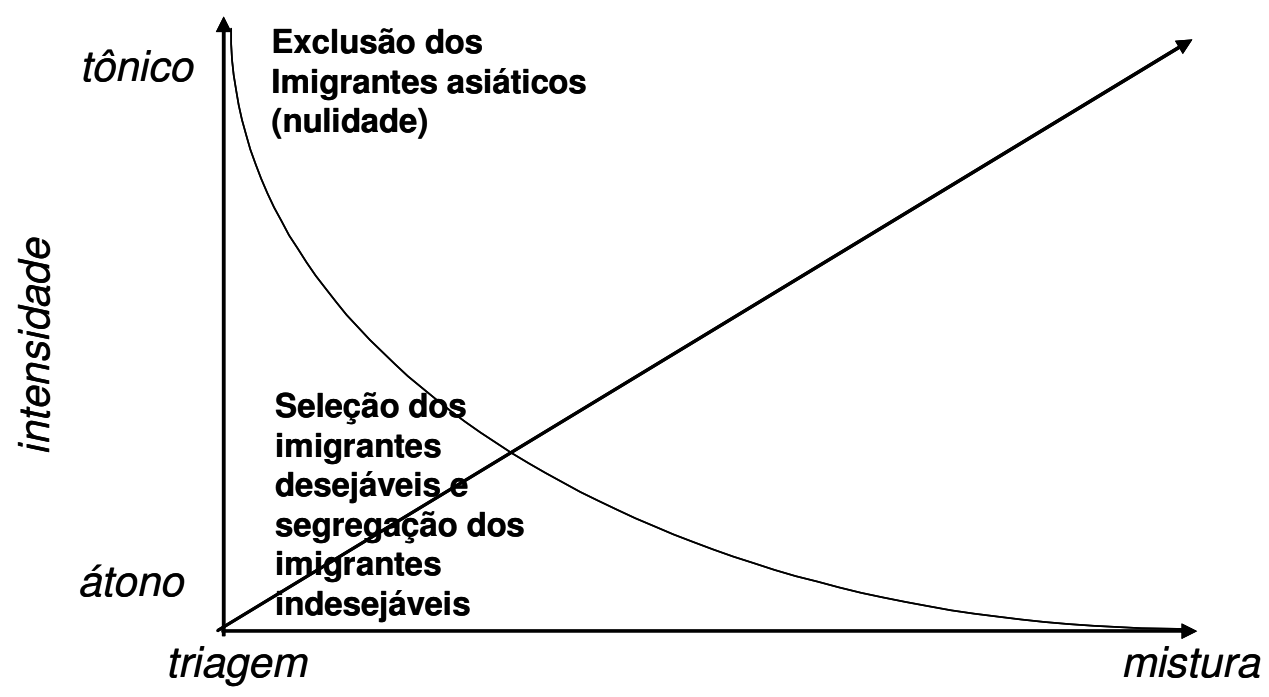

extensidade

Enquanto os asiáticos são excluídos categoricamente das discussões e, consequentemente, das propostas de política imigratória de Côrtes, certos imigrantes de origem europeia são excluídos por não corresponderem aos critérios de seleção estabelecidos no discurso analisado. Assim, as propostas de Côrtes constroem a imagem do imigrante ideal para o Brasil, ou seja, o imigrante trabalhador, com vigor físico e que pode ser assimilado. Ao mesmo tempo, o autor apresenta a representação do imigrante indesejável: com problemas mentais, indolente e racialmente inassimilável.

Mas a imigração não se encerra com a chegada do imigrante ao país. Há outra etapa, na qual o imigrante deve se integrar à nação brasileira para não se tornar uma ameaça a unidade nacional. Veremos, a seguir, as propostas de assimilação do estrangeiro apresentadas no texto de Menezes de Côrtes.

\section{Ajustamento, assimilação e facilidades na política imigratória}

Além da seleção dos imigrantes, o texto de Geraldo de Menezes Côrtes propõe ainda a assimilação dos imigrantes que cumprem todos os critérios de seleção estabelecidos em seu discurso. Veremos, ainda, como a outra função 
dos imigrantes é a de melhorar parcela da sociedade brasileira, elevando assim o nível cultural de parte da sociedade nacional.

Uma das preocupações no discurso de Côrtes é a de evitar que a presença do imigrante dissolva a unidade constitutiva da nação brasileira. Após selecionar os melhores imigrantes, segundo os critérios de seleção, é preciso pensar também em formas de integrar os imigrantes à sociedade brasileira, conforme vemos no trecho abaixo:

Para impedir que elementos estrangeiros no Brasil venham perturbar a nossa soberania ou serem fatores dissociativos ou enfraquecedores do espírito da nacionalidade é preciso cuidar-se da assimilação do alienígena e de seus descendentes. Daí decorre a necessidade imprescindível de associar-se ao problema imigratório o de assimilação (Côrtes, 1947: 6).

Existe, assim, a preocupação do enunciador em preservar a unidade nacional ("soberania" e "espírito da nacionalidade") que pode ser ameaçada pela presença dos imigrantes. A seleção, enquanto primeira etapa do processo imigratório, serve como um elemento facilitador para a realização da assimilação, na medida em que somente entram imigrantes portadores dos traços idealizados como os melhores para a sociedade nacional.

Segundo Girardet, a noção de unidade nacional apresenta, historicamente, duas formas sociais mais proeminentes: a religião e a política. Deixando de lado a questão religiosa (distante dos interesses imediatos de nosso trabalho), a ideia de unidade nacional tem em sua base o desejo por "uma sociedade homogênea e coerente, a condenação em nome do bem comum do recolhimento do indivíduo em si mesmo e em seus interesses, o temor dos cismas e das dissidências, a busca de uma fé comum e a exaltação das grandes efusões coletivas" (1987: 145). Para se constituir e, principalmente, manter a unidade nacional, por mais imaginária ${ }^{116}$ que ela seja, é preciso separar o que é incompatível com essa unidade e integrar o que se considera próximo ou idêntico a essa mesma unidade.

O contrato de assimilação tem como base a ideia de unidade cultural da nação. É a essa unidade que o imigrante deve integrar-se, eliminando, assim, a ameaça prevista de "dissociação nacional". A unidade nacional, segundo o

${ }^{116} \mathrm{O}$ próprio Girardet considera a ideia de unidade como parte dos mitos políticos da modernidade, ao lado de outras ideias como a do "salvador" da pátria, do passado glorioso e da ameaça, interna ou externa, à soberania nacional (1987). 
discurso de Côrtes, é constituída por diferentes elementos que a representam. Dentre ele, um dos principais, enquanto um valor, é a língua nacional:

\begin{abstract}
Urge aproveitar essa possibilidade de movimentar uma massa genuinamente brasileira, para de um lado elevar seu padrão cultural em contato com elemento estrangeiro e, de outro lado, para que se mesclando com o elemento alienígena - sob a sábia orientação do Estado, com seus órgãos de assistência social e de fiscalização - venha a concorrer não só para a mais fácil assimilação deste como para o crescimento de uma população cujos traços de união sejam a língua Nacional e os sentimentos comuns de amor ao que é seu e de seus descendentes (Cortês, 1947: 7).
\end{abstract}

Além da defesa dos valores nacionais, outro objetivo da assimilação é o de melhorar a formação da sociedade brasileira. Essa ideia de melhoramento parte do pressuposto de que parcela da sociedade não está ainda incluída no quadro axiológico ideal construído pelo enunciador, isto é, parte da sociedade brasileira ainda não está em conjunção com os valores constitutivos da unidade nacional. Os imigrantes europeus selecionados têm, então, a função de melhorar essa parcela da sociedade brasileira. Além do mais, ao manter um maior contato com a sociedade brasileira (para melhorá-la), a assimilação do imigrante passa a ser mais facilmente executada, segundo o discurso de Côrtes.

Sobre essa parcela da sociedade brasileira a que Côrtes faz referência, cabem ainda algumas explicações. Segundo o texto de Côrtes, as migrações internas se caracterizam, de um modo geral, pela movimentação de nordestinos para diferentes regiões do Brasil: basicamente, para a região amazônica (cuja indústria de extração de borracha estava em plena ascensão) e para o estado paulista, centro agrícola e industrial do país já naquele momento (Côrtes, 1947: 07). Vemos, então, que são os nordestinos a parcela da sociedade a ser beneficiada por meio do contato com o imigrante, como vimos acima. Consequentemente, os nordestinos são a parte "inferior" da sociedade brasileira que pode melhorar com 0 contato de imigrantes culturalmente "superiores", em benefício geral do próprio Brasil. Ao mesmo tempo, esse migrante nordestino pode, com sua presença maciça em locais estratégicos, tornar a assimilação do imigrante mais fácil, ajudando o país a integrar completamente o imigrante ao ideário nacional. Esse tipo de relação entre nordestinos e imigrantes europeus, orientado pela mistura, é aquela 
regida por grandezas desiguais, ou seja, uma "inferior" e outro "superior" (Fontanille e Zilberberg, 2001: 29). Por isso, a inclusão do imigrante na composição da sociedade brasileira pode ser considerada um enriquecimento, tal como definido por Zilberberg ${ }^{117}$ (2004: 89).

Podemos ainda acrescentar a esse raciocínio de Fontanille e Zilberberg (2001), a noção de ajustamento de Landowski. A assimilação não é, no discurso de Côrtes, apenas um processo de integração da alteridade no bojo da identidade. Enquanto uma interação entre sujeitos, a primeira etapa da relação entre imigrante e sociedade brasileira (ao menos em sua camada mais "popular") pode ser entendida como um ajustamento porque, em princípio, não existe uma intencionalidade por trás nem dos imigrantes (em seu fazer melhorativo) nem dos brasileiros (em seu fazer assimilacionista). Desse ajustamento, segundo o texto, pode surgir uma sociedade melhor, por meio do contato entre, de um lado, imigrantes de nível cultural superior e, de outro, parcela da sociedade brasileira desprovida dessa formação cultural "mais elevada", sendo ambos os lados unidos por elementos como a língua nacional e o sentimento de amor à pátria, surgidos a posteriori nessa interação.

Ocorre, assim, uma troca entre migrantes e imigrantes regida pela mistura. De um lado, o imigrante contagia o migrante nacional com um nível cultural maior (entendido como vontade e conhecimento voltados para o trabalho). De outro lado, o migrante nacional contagia o imigrante com elementos nacionais para torná-lo brasileiro. Em seguida, a língua nacional e o referido "amor à pátria" transformam ambos os sujeitos em cidadãos ideais para o país e os integram ao "panteão" dos bons cidadãos brasileiros que contribuem para o desenvolvimento econômico nacional.

Apesar de o fragmento acima mencionar apenas o padrão cultural, podemos retomar os critérios de seleção dos imigrantes para pensar que a assimilação dos imigrantes europeus serve para também melhorar a composição étnica (na verdade, racial, do ponto de vista do enunciador) e intelectual da sociedade brasileira, além de reforçar os laços cristãos e a ideologia capitalista.

\footnotetext{
${ }^{117}$ Zilberberg afirma que o enriquecimento é uma operação regida pela triagem e que consiste na inclusão de uma grandeza boa (2004: 89)
} 
Por isso, se pensarmos que os imigrantes desejados são os europeus, a finalidade dessa melhoria cultural da sociedade brasileira visa, em seu limite, a fundar uma "civilização europeia nos trópicos". Para concretizar esse objetivo, o Estado tem um papel fundamental:

É sabido que o padrão cultural mais elevado reage ao inferior e tende absorvêlo, e só se conseguirá assimilação, com o indiscutível benefício de elevação do nosso nível cultural no sentido sociológico, se houver a ação metódica, constante, e inteligentemente orientada do Estado na solução de todos os problemas que a própria assimilação envolve (Côrtes, 1947, p. 7).

Segundo o discurso de Côrtes, a melhoria da sociedade nacional ocorre por meio de uma mistura átona, uma vez que os dois elementos a serem misturados - migrantes nacionais e imigrantes - possuem níveis desiguais de pertinência. Nessa etapa, o valor predominante, como já vimos no capítulo teórico, é o da diversidade. Como a diversidade não é um valor positivo no discurso de Côrtes (que defende o valor da unidade nacional), é preciso ainda assegurar que a segunda etapa seja garantida (a da assimilação dos imigrantes propriamente dita). Por isso, ocorre o movimento que parte da mistura átona em direção à triagem tônica, em que o valor de unidade é preservado. Podemos representar esse movimento de mistura em um esquema tensivo, como o abaixo: 


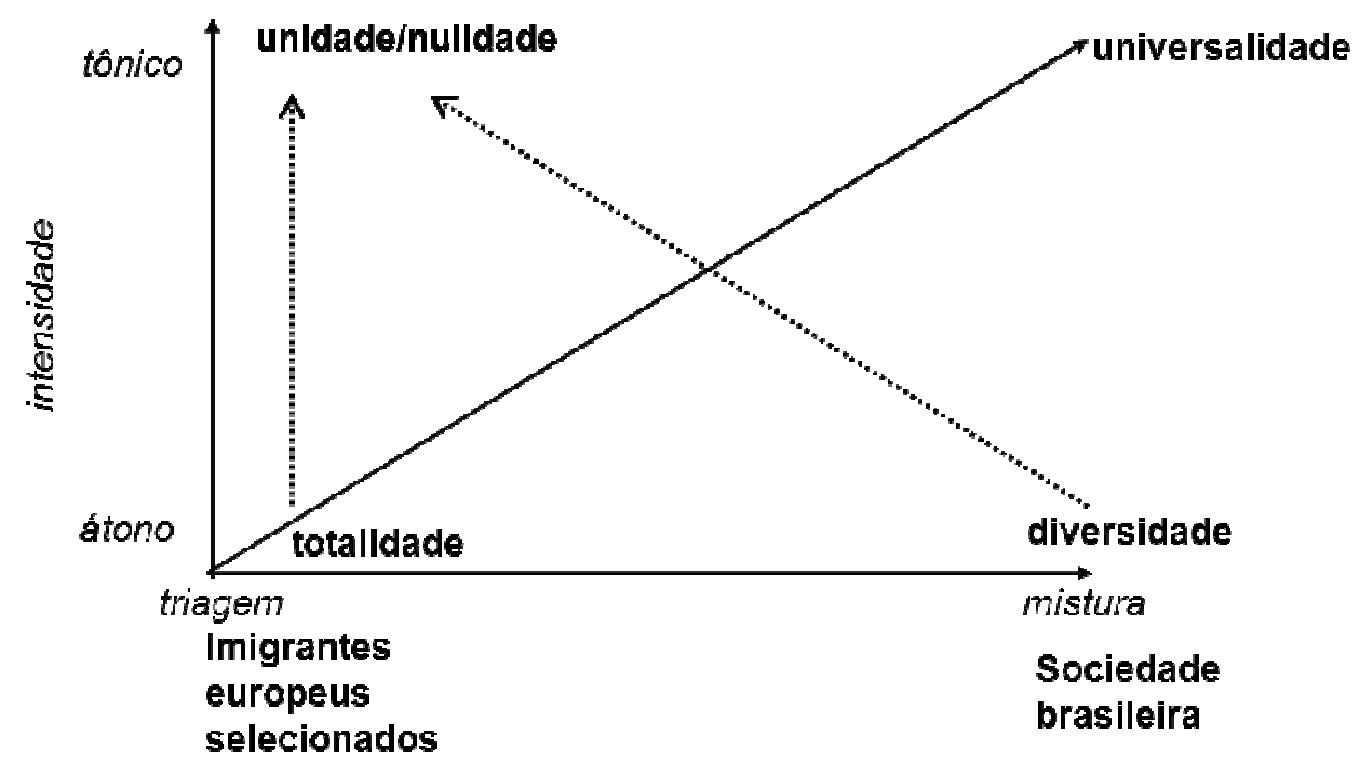

Vemos, assim, que a partir de uma totalidade construída por uma triagem átona - os imigrantes europeus selecionados - ocorre uma mistura, igualmente átona, na qual se encontra a sociedade brasileira de "nível cultural baixo". Entendemos que essa mistura é tão bem assimilada que gera a unidade nacional brasileira. Assim, com a integração do imigrante (assimilação), é possível, pela proposta de Côrtes, acrescentar, à unidade nacional brasileira já existente, ambos os sujeitos (migrantes nacionais e imigrantes selecionados $)^{118}$.

No entanto, o processo de assimilação do imigrante selecionado não é um percurso que se desenvolve automaticamente. Para reter e integrar aquele que é considerado o melhor imigrante para o país, é preciso estabelecer todo um esquema de manipulação que vai propor um contrato para que o imigrante permaneça no país e, mais do que isso, se integre à sociedade nacional. Por isso, Côrtes propõe uma série de medidas para abrigar adequadamente o imigrante, além de oferecer outros suportes para convencer o imigrante a se instalar no país e a se unir definitivamente à sociedade brasileira.

\footnotetext{
${ }^{118}$ Em um exercício de imaginação, podemos afirmar que se, no discurso de Côrtes, todos os tipos de imigrante pudessem ser aceitos em solo nacional, a diversidade constituída no esquema tensivo acima se dirigiria à universalidade e não à unidade.
} 
A principal medida é a sua proposta de colonização, que merece destaque para Côrtes porque visa, inicialmente, à fixação do imigrante. Mais do que oferecer terras cultiváveis ao imigrante, torna-lo proprietário de terras é, como já foi dito, um elemento fundamental para a política de assimilação do imigrante no país:

Ninguém desconhece o fato da propriedade fixar o estrangeiro à Pátria adotiva, nem tampouco o papel que o sentimento de posse representa para sua assimilação (Cortês, 1947: 7).

Como a propriedade é um dos principais meios de se assimilar o imigrante, nada mais natural do que the facilitar a compra de terras. Dessa forma, o imigrante, segundo o discurso de Côrtes, não possui apenas o papel temático de "trabalhador" (poder/saber/querer-fazer), mas também o de "proprietário" (poder/saber/querer-ser), como vimos na seção anterior.

A proposta de Côrtes ainda procura pensar na instalação de toda infraestrutura para auxiliar a produção agrícola da propriedade do imigrante. Dessa forma, o local onde se estabelecem os imigrantes deve ser escolhido também com o intuito de se desenvolver, posteriormente, uma vila e, se possível, uma cidade. Para isso, devem ser aproveitadas as terras devolutas próximas de localidades já existentes ou que tenham meios de transporte desenvolvidos, facilitando o acesso a essas áreas. Devem também ser utilizadas as propriedades federais, estaduais e municipais e as terras não cultivadas, mas cultiváveis, decorrentes de desapropriação ${ }^{119}$ (Côrtes, 1947: 11). No trecho abaixo, o enunciador realça também a sua percepção subjetiva como prova de validade para a sua proposta de vendas das terras aos novos imigrantes:

Há em inúmeras partes do Território Nacional, terras devolutas que estão sendo vendidas pelos Estados por preço ínfimo, prestando-se a um verdadeiro comércio de vendas e revendas de terras sem a devida exploração, que tanto nos convém para aumento da produção. É o que pude observar no Estado do Paraná e o que por informações várias, sei ocorrer em outros Estados (Côrtes, 1947: 7).

\footnotetext{
${ }^{119} \mathrm{O}$ texto não explica se a desapropriação decorre de ações anteriores ou se é realizada para criar uma localidade própria para os imigrantes.
} 
Além dessas propriedades, que podem ser vendidas ao imigrante ${ }^{120}$, o texto ainda trata da organização do núcleo de colonização em vista de uma maior facilidade de assimilação do imigrante. $O$ texto prevê a mistura dos imigrantes com brasileiros (estes em maior quantidade), como já foi dito anteriormente. Por essa razão, as residências da colônia devem, em princípio, estar próximas umas das outras para incentivar o contato entre imigrantes e brasileiros, o que facilita o processo de assimilação. Outra forma proposta para aumentar as chances de assimilação ocorre com o incentivo à presença de clubes e igrejas (para promover uma vida social ativa), de escolas para os filhos dos imigrantes (para o ensino dos valores nacionais e da língua portuguesa, além do ensino agrícola), de serviços médico e dentário, de cooperativas de venda, consumo e crédito, de correio e de pequenas oficinas de ferreiro, serralheiro e carpinteiro (Côrtes, 1947: 11).

É preciso, segundo o texto, eliminar todos os possíveis obstáculos para a integração do imigrante à nação brasileira. E para isso ocorrer, as propostas de Côrtes chegam a detalhes que, como vimos, preveem o maior controle de instalação de toda infraestrutura para que o imigrante seja assimilado. Toda essa estrutura proposta visa a um melhor acolhimento e, por consequência, um melhor estabelecimento do imigrante no país. Estando bem estabelecido, com toda uma estrutura social e assistencial a sua disposição, o enunciador crê que o imigrante pode se fixar no país.

Por meio dessas facilidades à instalação do imigrante, o enunciador constrói uma manipulação por tentação e por sedução, ou seja, essas facilidades servem para mostrar ao imigrante selecionado que o país deseja a sua instalação e, principalmente, a sua integração completa ao país e à sociedade brasileira.

Vimos, até agora, todas as propostas referentes à assimilação do imigrante no país. De modo geral, há duas isotopias temáticas que permeiam o discurso de Menezes Côrtes: a cultural e a econômica. A primeira aparece em suas considerações sobre os benefícios que parte da sociedade brasileira, desprovida de um nível cultural considerado elevado, pode obter pelo contato

\footnotetext{
${ }^{120} \mathrm{Um}$ traço que chama a atenção no texto se refere ao fato de o enunciador estipular o prazo de cinco anos para transferir definitivamente a propriedade para o imigrante, o que revela a sua preocupação em fixar efetivamente o estrangeiro em solo brasileiro (Côrtes, 1947: 11). Esse procedimento garante, ainda, que esse imigrante não vai se aproveitar dos benefícios que ele pode ter por sua condição de estrangeiro.
} 
direto com os imigrantes. A segunda aparece de forma mais detalhada por meio do objetivo claramente declarado de se ter mão de obra imigrante qualificada para alavancar o desenvolvimento econômico do país. Prosseguindo sua isotopia economicista, o texto trata rapidamente do capital estrangeiro e do turismo. Para estimular essas duas atividades, o texto fala da propaganda do país no exterior:

\begin{abstract}
Aplicação de capitais estrangeiros e turismo.
A propaganda deve ser de forma a ressaltar principalmente:

1‥ - As condições de vida fácil sob os aspectos de: alimentação, habitação (hotéis) e comunicações (transportes, correios e telégrafos).

$2^{\circ}$. - As facilidades para instalação de indústrias, quais sejam: matérias primas, possibilidade de consumo interno e dos transportes.

3․ - Direitos e obrigações dos estrangeiros no País. Possibilidade de naturalização. Vantagens do naturalizado (Côrtes, 1947: 9).
\end{abstract}

Todos os três itens focam na ideia de "facilidade" no país, ou seja, na ausência de obstáculos e de dificuldades, seja na vida prática do cotidiano, seja na estrutura ou nas condições que o país oferece ao estrangeiro e, particularmente, ao imigrante. A facilidade se converte, inclusive, em vantagens no caso da naturalização.

As facilidades e os privilégios têm um objetivo claro: criar a imagem de um país que deseja receber bem os imigrantes dispostos a trabalhar ou a investir na instalação de indústrias. Além disso, o texto também toca em outras formas de contribuição ao desenvolvimento econômico nacional vindas do estrangeiro: o turismo e a entrada de capital estrangeiro ${ }^{121}$.

O texto constrói, assim, a imagem de um país que deseja a presença, a participação e a ajuda do estrangeiro e, principalmente, do imigrante (mas somente do imigrante que preencha as condições estabelecidas pelos critérios de seleção). Mais do que isso, as propostas de Côrtes constroem a imagem de um país acolhedor no que se refere à instalação e à fixação dos imigrantes, reforçando a tentativa de convencer o imigrante a se integrar à nação brasileira.

Tanto a exclusão de determinados grupos ou indivíduos como a assimilação dos imigrantes europeus, tal como estabelecidas no discurso de

\footnotetext{
${ }^{121}$ Pressupõe-se que o capital estrangeiro se refira a investimentos na indústria nacional ou mesmo na instalação de empresas estrangeiras no país. De qualquer forma, a questão dos investimentos estrangeiros fica restrita a esse parágrafo.
} 
Geraldo de Menezes Côrtes, fazem parte de uma reelaboração do processo imigratório brasileiro. Em última instância, tal projeto visa a um maior desenvolvimento econômico e a uma melhora da constituição cultural e racial de parcela da sociedade brasileira. Para que esse projeto seja bem sucedido, é preciso ainda planejar bem todas as etapas do processo imigratório, assim como estabelecer uma instância burocrática centralizada responsável pelo controle de todos os detalhes. Assim, o planejamento e a centralização da política imigratória são parte de um projeto que deseja controlar todos os detalhes possíveis do processo imigratório para melhor aproveitar o material humano que entra no país. Veremos, então, as características gerais do planejamento e da centralização na próxima seção.

\section{A lei como discurso totalizante para a política imigratória no Brasil}

Como vimos acima, a política imigratória não deve, na concepção de Côrtes, tratar apenas da seleção dos possíveis imigrantes. Essa política precisa também pensar na assimilação do imigrante, na medida em que ele chega para auxiliar o Brasil. É preciso, assim, planejar toda a estrutura e organização necessárias para receber e integrar o imigrante e, assim, explorar suas potencialidades em prol do país. O enunciador mostra, assim, que não está apenas voltado para a detecção dos problemas, mas também quer propor formas de solucioná-los.

Veremos como as soluções propostas por Côrtes apresentam uma perspectiva totalizante do processo imigratório ao detalhar tudo o que deve ser feito para melhor acolher e integrar o imigrante à sociedade nacional.

As soluções apresentadas pelo texto só podem se tornar uma realidade se houver um planejamento. A lógica que rege esse discurso é a de apresentar os elementos necessários, em todos os detalhes possíveis, para a criação de um bom planejamento que leva a uma execução apropriada de seus princípios. Em resumo, o governo, enquanto instância responsável pela política imigratória, precisa planejar primeiro (ou seja, adquirir a competência cognitiva necessária) para depois executar o plano (isto é, partir para o desempenho com sucesso praticamente garantido): 
Estamos numa boa situação para passarmos ao domínio das realizações práticas. Para tanto precisamos planejar objetivamente e executar de acordo com as previsões e com a vontade que podem ter os cérebros esclarecidos (grifos do autor, Cortês, 1947: 7-8).

A "boa situação" a que o enunciador se refere está ligada à organização jurídica da colonização e da concessão de terras, parte inerente de qualquer processo imigratório que deseja assentar o imigrante no país. Dessa forma, o universo jurídico sobre a imigração serve como quadro axiológico para orientar o planejamento (a competência) e a execução (o desempenho) da política imigratória brasileira. Para o enunciador, a situação jurídica já oferece um bom respaldo para o planejamento e a execução da política imigratória, principalmente por eliminar ou diminuir a possibilidade de ações contrárias à integração do estrangeiro na sociedade brasileira:

O corpo de leis a respeito de imigração e dos problemas de assimilação já satisfaz plenamente, quer no que se refere à 'colonização e concessão de terras', quer no que se refere à 'cota de percentagem de entrada dos estrangeiros' (para defesa do índice étnico atual), quer sobre percentagens de distribuição dos estrangeiros em zona rural de colonização com predominância do elemento nacional para evitar ou debelar os quistos existentes, quer regulando as obrigações e direitos do estrangeiro face às autoridades brasileiras, quer prevendo medidas para maior facilidade de adaptação ao meio nacional dos brasileiros descendentes de estrangeiros (Côrtes, 1947: 8).

O trecho acima mostra a aprovação do enunciador em relação ao modo como a lei trata da assimilação do imigrante porque assim se pode "evitar ou debelar os quistos existentes", ou seja, acabar com os núcleos coloniais isolados. O chamado "quisto étnico" é, no discurso de Côrtes, um antiobjeto que pode ameaçar a existência da unidade nacional. Por isso, ele deve ser evitado ou, caso já esteja presente, ser eliminado pela ação do governo e das leis que tratam da questão imigratória no país. Assim, a assimilação dos imigrantes, respaldada pelas leis brasileiras, pode evitar a formação de novos "quistos étnicos" que ameaçariam a unidade nacional.

Mesmo ressaltando os aspectos positivos na política imigratória, sobretudo na parte jurídica do tema, o enunciador ainda percebe falhas ou insuficiências que, se sanadas, podem melhorar ainda mais o planejamento e a execução da política imigratória brasileira. A principal falha detectada se refere, nesse caso, à ausência de uma instância única responsável pela administração 
do processo imigratório. Essa ausência faz com que Côrtes proponha, como projeto de lei, a criação de um órgão centralizador, respaldado inclusive em um artigo da Constituição vigente (artigo 162, citado no texto) ${ }^{122}$ (Côrtes, 1947: 08). Côrtes propõe, ainda como uma forma de eliminar as falhas do processo imigratório, um "Plano de Conjunto" que organiza toda a parte administrativa do governo em relação à imigração no país. Dessa maneira, o enunciador reforça a ideia de um processo imigratório planejado no qual todas as etapas são controladas e fiscalizadas em sua totalidade:

\begin{abstract}
Entretanto, para que essas leis produzam os seus efeitos é preciso que seus preceitos tenham repercussão num Plano de Conjunto e que estejam definidas as atribuições da administração pública encarregada de pô-lo em execução e que haja uma direção encarregada de fiscalizar a obediência ao que a lei e o plano preveem, solicitando ao Governo as providências que se tornarem necessárias (Côrtes, 1947: 8).
\end{abstract}

Uma crítica, implícita, é feita ao Conselho de Imigração e Colonização, da qual, lembremos, Côrtes faz parte: a lentidão de suas decisões (Côrtes, 1947: 10). Por isso, o sucesso da política imigratória depende da centralização das decisões e das operações referentes ao processo imigratório em todas as suas etapas. Essa ideia de centralização das decisões deve ainda ser aplicada para os assuntos verdadeiramente pertinentes (do ponto de vista do enunciador) da política imigratória:

Sem perdermos de vista a grande realidade, temos vivido preocupando-nos com pequeninos casos de imigração, sem montarmos um Plano de Conjunto que atenda aos interesses nacionais e que preveja todas as providências para a solução integral do problema imigratório, inclusive as questões relativas à distribuição do estrangeiro no ambiente brasileiro e as medidas aconselháveis para a mais rápida assimilação do alienígena (Côrtes, 1947: 8).

Dessa forma, o "Plano de Conjunto" tem a intenção de ser um plano o mais englobante e totalizante possível (“...que preveja todas as providências..."). O "Plano de Conjunto" chega aos limites da totalização das ações e dos demais aspectos do tema imigratório brasileiro, com especial destaque para a seleção, o assentamento e a assimilação do imigrante, em vistas de uma eliminação ("solução integral") dos problemas pelos quais o

\footnotetext{
${ }^{122}$ Citamos a seguir o referido artigo: “Art 162 - A seleção, entrada, distribuição e fixação de imigrantes ficarão sujeitas, na forma da lei, às exigências do interesse nacional”.
} 
processo imigratório está passando naquele momento, segundo a perspectiva de Côrtes.

Como se vê no trecho acima, o "Plano de Conjunto" coloca os interesses nacionais como fonte de orientação da política imigratória (reiterando, assim, a menção explícita a um artigo da Constituição vigente naquele momento, como vimos). Dessa forma, o plano proposto por Côrtes tem também, como um de seus focos, a defesa da unidade nacional.

Todas essas questões discutidas (leis, planejamento e execução) só são plenamente realizadas com eficiência se houver uma instância burocrática central. O enunciador, tendo em vista a distribuição e a assimilação do imigrante, considera necessária, assim, a criação de um órgão central (e também centralizador) subordinado diretamente à Presidência da República ${ }^{123}$.

\begin{abstract}
Um órgão central que poderia ser chamado Departamento Nacional de Imigração e Assimilação, diretamente subordinado ao Presidente da República, com as responsabilidades centralizadoras, coordenadoras e fiscalizadoras que se impõem para enfrentar as soluções práticas do problema de imigraçãoassimilação resolverá o problema, podendo extinguir-se o Conselho de Imigração e Colonização (Côrtes, 1947: 10) ${ }^{124}$.
\end{abstract}

A proposta de criação do Departamento Nacional de Imigração e Assimilação (doravante D.N.I.A.) surge como uma forma de centralizar todo o processo imigratório em um único órgão. O D.N.I.A. constitui-se, no discurso de Côrtes, em um ator que sincretiza os dois destinadores do nível narrativo: de um lado, o destinador-manipulador, que coordena as ações voltadas para a imigração, ou seja, a seleção, a instalação e a assimilação do imigrante; de outro lado, o destinador-julgador, que fiscaliza todas as ações relacionadas à imigração e aos imigrantes ${ }^{125}$.

Dessa forma, as propostas de Côrtes apresentam o processo imigratório em todas as suas etapas (seleção, colonização e assimilação) e em todos os

\footnotetext{
${ }^{123}$ Contudo, adiante, o autor afirma que se o Ministério da Economia fosse criado, seria razoável pensar que o órgão central de controle e planejamento da imigração ficasse subordinado a esse novo ministério, reforçando, assim, seu ponto de vista economicista (Côrtes, 1947: 10).

${ }^{124}$ A substituição do nome do órgão responsável pela imigração no Brasil não é ingênua. Ao colocar no lugar de "Colonização" a denominação "Assimilação", o enunciador revela a sua prioridade no processo imigratório brasileiro: a integração do imigrante à sociedade nacional.

125 Não trataremos, contudo, de analisar todos os detalhes da proposta de criação do D.N.I.A. porque consideramos suficiente o que foi exposto sobre a centralização e a totalização das propostas de Côrtes. Além do mais, a análise de detalhes burocráticos pouco contribuiria para o que já foi analisado das propostas de Côrtes.
} 
seus aspectos burocráticos, tentando, assim, não deixar nenhum detalhe escapar de suas considerações.

\section{Considerações parciais}

No início desta análise, partimos da hipótese de que haveria um traço centralizador e totalizante que caracteriza o discurso de Côrtes. Essas duas características determinam o modo como o enunciador entende a imigração no Brasil de sua época e, ao mesmo tempo, são as responsáveis pelas propostas de mudanças no processo imigratório brasileiro. Como formas de propostas, temos os critérios de seleção dos imigrantes, assim como sua assimilação. É por meio dessas duas operações que pudemos observar como o texto de Côrtes separa os "bons imigrantes" dos "maus imigrantes".

Se o processo imigratório ideal para Côrtes deve ter todos os seus detalhes estabelecidos, nada mais natural do que esperar que, desde o início do processo, a seleção seja controlada por esse mesmo princípio centralizador e totalizante. Ao promover a exclusão dos imigrantes de origem asiática, vemos como o autor estabelece uma política imigratória de base econômica que possui traços de preconceito, sobretudo quando utiliza o termo "raça" para justificar a exclusão dos asiáticos.

Além dessa triagem tônica, que exclui os imigrantes de origem asiática, há também a triagem átona, que produz os critérios de seleção para entrada dos imigrantes desejados pelo enunciador, que os considera como os melhores para o país. Há, assim, uma seleção que separa os indivíduos que não se identificam com os critérios estabelecidos no discurso para entrar no país: ter vontade para o trabalho, saúde, inteligência, além da religião, da ideologia e da raça branca.

O programa da assimilação tem por objetivo fixar os imigrantes selecionados, pois se estabelecendo definitivamente, mais garantida está a contribuição do imigrante ao desenvolvimento econômico nacional. A assimilação quer ainda integrar imigrantes de origem europeia para fazer parte da unidade nacional brasileira, fonte dos valores a ser defendidos, segundo as proposta do enunciador. Dessa foram, os imigrantes, anteriormente selecionados, devem se submeter ao contrato de assimilação e, para isso, 
passam por uma série de manipulações baseadas na tentação e na sedução. Mas antes mesmo desse contrato de assimilação, os imigrantes devem interagir com os indivíduos das classes "inferiores" (do ponto de vista do enunciador) para melhorar o nível cultural da população brasileira, servindo assim como um elemento de melhoramento de parte da sociedade brasileira, como vimos. O imigrante tem, assim, duas funções no texto de Côrtes: auxiliar no desenvolvimento econômico nacional e contribuir para a melhoria da sociedade brasileira.

Por isso, a assimilação, no texto de Côrtes, se torna uma prioridade, pois assim é possível defender a unidade nacional da ameaça dos "quistos étnicos". Essa característica fica mais evidente quando o enunciador substitui o termo "Colonização" (presente no Conselho de Imigração e Colonização) pelo de "Assimilação" (do Departamento Nacional de Imigração e Assimilação). Essa mudança de nome é o reflexo da concepção de imigração presente em Côrtes, que pretende explorar todas as potencialidades do imigrante selecionado.

A seguir, veremos outro tipo de texto sobre a imigração no Brasil. Tratase de um estudo antropológico sobre a comunidade japonesa no Brasil e o processo de aculturação pela qual ela estava passando naquele momento.

\subsection{Avaliações a respeito do modo de ser dos imigrantes japoneses em um artigo de antropologia}

\section{Introdução}

Depois de pouco mais de 50 anos do início da imigração japonesa, a sociologia e a antropologia já realizam uma série de estudos sobre a comunidade nipônica no Brasil. Dentre esses textos, selecionamos o artigo de Ruth Cardoso, intitulado "O papel das associações juvenis na aculturação dos japoneses". Esse artigo foi publicado em 1959 na Revista de Antropologia e está dividido em quatro partes: "I. 'Issei' e 'Nissei' no Brasil”"126; "Il. Associações de 'nissei"”; "III. A associação de jovens e a formação da opinião"; "IV. Conclusões".

\footnotetext{
${ }^{126}$ Issei é o imigrante japonês propriamente dito. Nissei é o filho dos imigrantes japoneses nascido no Brasil.
} 
Como o título do artigo deixa claro, o objetivo do estudo de Ruth Cardoso é compreender o processo de aculturação pelo qual o filho do imigrante japonês está passando e o papel das associações juvenis nesse processo de transformação. Seu estudo passa, assim, pela explicitação dos conflitos dentro da colônia japonesa, advindos de uma tensão geracional e pela pressão, vinda da sociedade brasileira, para o filho do imigrante ser assimilado. O estudo de Ruth Cardoso ainda mostra o "real" interesse do nipônico e de seus filhos no processo de assimilação: a ascensão social dos nisseis (que ocorre, principalmente, pela mudança de localidade deles, que deixam o campo para trabalhar em cidades).

Uma diferença marcante do estudo de Ruth Cardoso em relação aos demais textos analisados neste capítulo é que não há nenhum tipo de proposta para a política imigratória brasileira. Seu estudo, como dissemos acima, se restringe a compreender como o nissei está se aculturando ${ }^{127}$, ou seja, está adquirindo traços da cultura brasileira (ao mesmo tempo em que vai perdendo elementos da cultura japonesa) e como a associação juvenil cumpre o papel de auxiliar no processo de aquisição desses traços.

Antes de entrar na discussão sobre as associações e a aculturação do nissei, o trabalho de Ruth Cardoso apresenta alguns dados estatísticos a respeito dos imigrantes japoneses no Brasil. Esses dados se referem à distribuição geográfica, à faixa etária e ao gênero dos imigrantes presentes no país. Esses dados comprovam que a imigração japonesa foi primordialmente familiar, ou seja, os grupos que vieram para o Brasil foram constituídos por indivíduos que mantinham algum tipo de parentesco (Cardoso, 1959: 102-103). Começaremos, então, nossa análise pela caracterização da família japonesa no Brasil e sua situação particular no período pós-guerra. Examinaremos, assim, como a família japonesa passa por transformações em um momento histórico que coloca em xeque seus valores tradicionais e sua identidade.

\section{A família nipônica no Brasil: tradição e mudanças}

\footnotetext{
${ }^{127}$ A aculturação é um conceito sociológico que significa a transformação dos padrões culturais de um ou dos dois grupos sociais em contato. Segundo Cuche, a aculturação não pode ser confundida com a assimilação, pois esta é a etapa final daquela e, muitas vezes, não se realiza completamente. Em outras palavras, a aculturação pode ser tomada como um processo durativa, enquanto a assimilação é um processo terminativo raramente alcançado se pensarmos em termos de eliminação completa de uma cultura para que a outra continue existindo (Cuche, 2002: 115-116).
} 
Como foi dito acima, a imigração japonesa se caracteriza primordialmente pela vinda de famílias inteiras para o Brasil, traço encontrado em outros grupos imigratórios, mas sem a mesma força. Uma das consequências dessa característica é a entrada e a manutenção das tradições japonesas no espaço brasileiro. A permanência dessas tradições só é possível, segundo o texto, por conta do isolamento das colônias japonesas instaladas no Brasil, como deixa claro o seguinte trecho:

\begin{abstract}
A distribuição neste grupo repete 0 movimento da distribuição total da população, isto é, não se trata de grupo formado principalmente por homens adultos. Podemos afirmar, e a história dos imigrantes o confirma, que os japoneses vieram para o Brasil com suas famílias, para a agricultura; e se localizaram em algumas regiões, onde por compra ou arrendamento de terrenos se reuniram em núcleos de convivência, situação que, pelo relativo isolamento desses núcleos, facilitou a manutenção de certos padrões da cultura de origem (Cardoso, 1959: 102).
\end{abstract}

Ocorre, assim, uma continuidade de sentidos por meio do sujeito "família japonesa". Como a colônia japonesa é fechada em relação à sociedade brasileira, a tradição carregada pela família que chega ao Brasil é facilmente preservada. É como se houvesse uma unidade japonesa dotada de sentido dentro de uma unidade brasileira, sem diálogos ou contatos, apenas uma coexistência no mesmo espaço com valores e programas narrativos distintos.

Nesse universo de sentidos que acompanha a família japonesa em seu caminho para o Brasil, há a preocupação, já existente no Japão, com a educação de seus filhos. A educação dos mais novos significa, segundo a perspectiva dos imigrantes japoneses, ensinar os comportamentos e os valores da sociedade nipônica, como podemos ver no seguinte fragmento:

Tratando-se, porém, de imigração familial, logo veio a colocar-se o problema da educação dos descendentes, e os velhos imigrantes, 'issei' na designação japonesa, pretenderam tornar o 'nissei' um herdeiro da tradição cultural japonesa (Cardoso, 1959: 102).

Dessa forma, a educação do nissei, foco de preocupação da família japonesa, visa à continuidade dos valores japoneses, mesmo em solo estrangeiro, não permitindo, a princípio, a saída do nissei para outros programas narrativos que não sejam os da comunidade japonesa. Pelo 
programa narrativo da família japonesa, o nissei é o sujeito responsável pela preservação dos valores tradicionais. Ocorre, assim, uma primeira relação entre a família japonesa e o nissei, que pode ser compreendida, em termos semióticos, como uma relação entre destinador-manipulador e destinatáriosujeito, respectivamente.

Além da educação dos filhos ensinada pela família, principalmente em relação ao comportamento, há também (nos primeiros anos da imigração japonesa no Brasil) escolas da comunidade nipônica que ministram as mesmas matérias do currículo escolar japonês:

O papel da família na educação nipônica é muito importante, e à total autoridade paterna cabe formar o espírito de disciplina e obediência nos mais jovens. Esta parte da educação foi e é cumprida pelos 'issei', e para complementá-la apareceram as escolas japonesas, com professores, currículos e programas iguais aos do curso primário japonês. Antes da guerra essas escolas funcionavam abertamente, com seus 6 anos de ensino, tanto em zonas rurais como urbanas, onde houvesse um número de japoneses suficiente para mantê-las (Cardoso, 1959: 102-104) ${ }^{128}$.

De um lado, a tradição, enquanto uma continuidade do /saber-ser/ (“obediência" e "disciplina"), é imposta por meio de uma manipulação por intimidação, na qual o contrato fiduciário se constrói, para o nissei, na base da obediência à autoridade familiar e em uma disciplina que controla os desejos individuais em favor dos interesses coletivos da comunidade. Por outro lado, a tradição ensinada na escola é também um /saber-ser/, complementada por um /fazer-saber/, enquanto conhecimento transmitido pela escola nos moldes determinados pelo ensino japonês.

No entanto, a escola japonesa não se limita ao ensino da língua japonesa e de outras disciplinas do currículo escolar japonês. Os sentimentos de patriotismo e de civismo são igualmente ensinados pela escola e fazem parte da modalidade do /saber-ser/ em sua dimensão social e pública (e não familiar e privada) como podemos observar no trecho abaixo:

\begin{abstract}
A sua função principal [da escola] era ensinar o japonês, informar o aluno sobre o Japão, desenvolvendo o sentimento de patriotismo e civismo, e complementar o papel da família na imposição de uma disciplina rígida e de uma consciência de superioridade racial e cultural (Cardoso, 1959: 104).
\end{abstract}

\footnotetext{
${ }^{128}$ Vimos que todas as escolas de imigrantes (principalmente as das colônias japonesas, alemãs e italianas) foram fechadas durante o governo Vargas.
} 
Há, assim, uma modalidade do /saber/ que se desdobra temática e figurativamente da seguinte forma: o /saber/ atribuído pela família e o ensinado pela escola. Quando unidos, esses dois /saberes/ formam um sujeito japonês completo, mesmo que nascido no Brasil.

Pelo trecho acima, a família e a escola são também responsáveis pelo ensino de outra tradição japonesa aos mais novos: imbuí-los da "consciência de superioridade racial e cultural", ou seja, um /saber-ser-superior/. Em outras palavras, um traço modal característico do japonês é o de /saber-ser/ melhor do que outros, seja racialmente seja culturalmente, segundo o texto de Cardoso.

$\mathrm{Na}$ organização familiar do japonês, existe ainda outra preocupação, além da educação dos filhos: o cuidado com os pais. De um modo geral, o filho mais velho é o responsável pelo cuidado de seus pais (quando não podem mais cuidar de si mesmos) e, consequentemente, com a propriedade deles, enquanto os demais filhos são incentivados a continuar os estudos até adquirir uma profissão e a sua independência financeira:

\footnotetext{
Observa-se mesmo uma seleção intencional dos pais, escolhendo um ou alguns filhos para continuarem os estudos depois do curso primário e da escola japonesa. Tal escolha é feita na base da maior vontade de estudar, do aproveitamento na escola, enquanto aos outros filhos, principalmente ao mais velho, cabe continuar os negócios da família, e encarregar-se de sua manutenção. O filho mais velho, herdeiro da autoridade paterna, deve estar muito ligado aos padrões familiares tradicionais, enquanto os outros têm oportunidade de encontrar uma profissão urbana. Essa regra não é rígida, e muitas vezes o primogênito recebe também instrução escolar completa, podendo então exercer uma profissão que the permita independência (Cardoso, 1959: 104).
}

Enquanto o filho mais velho prossegue com a tradição (como o herdeiro dos valores japoneses), os outros filhos podem se afastar da família para estudar (geralmente, na cidade), entrar em contato com brasileiros e, assim, obter uma profissão para ascender socialmente, segundo a antropóloga. Para se conquistar a ascensão social, o nissei precisa obrigatoriamente interagir com brasileiros e, assim, adquirir os valores e os comportamentos da sociedade brasileira. Por isso, vemos que, no seio da família japonesa, os filhos podem cumprir dois papéis temáticos distintos: aos mais velhos, fica reservado o papel temático de "cidadão japonês", herdeiro e portador da 
tradição oriental; aos demais filhos, o papel de "sujeito bem sucedido" em termos sociais e econômicos. Por conta dessa relação com os filhos, a família japonesa se encontra, de certa forma, em uma encruzilhada: de um lado, deseja a ascensão social de seus filhos (ou de parte deles) e, de outro, não quer abrir mão de certos valores tradicionais para que isso ocorra.

Além dessa diferenciação de papeis temáticos dos filhos dos imigrantes japoneses, Cardoso mostra que o espaço é importante para se pensar nas relações da família japonesa, seus filhos e os brasileiros:

Porém, o 'nissei', mais que seus pais, é obrigado a ultrapassar este círculo fechado de convivência, e se nas cidades consegue isto mais cedo, através do grupo de brinquedo e vizinhança e da frequência ao 'Grupo Escolar' concomitante à da escola japonesa, em zonas rurais mantém-se muito mais ligado à família e ao núcleo japonês, mesmo quando frequenta o curso primário, onde aprende o português (Cardoso, 1959: 104).

Vê-se no trecho acima uma clara oposição entre cidade vs. campo. Essa oposição é fundamental para se compreender as possibilidades de aculturação do nissei à sociedade brasileira. Ainda segundo esse trecho, a interação com a sociedade brasileira é uma necessidade (/dever-ser/) da qual o nissei não tem como escapar. Porém, esse "convívio" pode ocorrer mais facilmente com os nisseis que já residem na cidade, enquanto o mesmo não ocorre com os que vivem no interior (mais especificamente na colônia japonesa). Isso ocorre porque, segundo a lógica do texto, viver na comunidade japonesa dificulta a abertura para os valores brasileiros e, consequentemente, facilita a manutenção das tradições nipônicas, como já dissemos.

Ainda durante a Segunda Guerra Mundial, surgem pressões para o imigrante japonês (e principalmente para seus filhos) se aculturar. Podemos compreender essa pressão da sociedade brasileira como uma forma de manipulação por intimidação e por tentação para que o imigrante japonês aceite o contrato de assimilação e passe a integrar a sociedade brasileira. Além disso, entendemos que essas pressões decorrem, em parte, da sociedade brasileira compreender que a aculturação é necessária para diminuir, ou mesmo eliminar, a sensação de ameaça à integridade nacional que a presença dos japoneses suscita com seu isolamento. 
Por isso, após o final da Segunda Guerra Mundial, parte da colônia japonesa começa a reconhecer que o nissei é, na realidade, brasileiro e, como tal, deve ter comportamentos brasileiros, mas sempre preservando os valores fundamentais da cultura japonesa. É nesse momento que começa a ocorrer a passagem da triagem para a mistura em termos de sociabilidade. Em outras palavras, o que está fechado começa a se abrir e a se misturar com outra grandeza (a sociedade brasileira). Contudo, como aponta Fiorin (2009), a mistura não ocorre sem um princípio prévio de seleção das grandezas que se misturam. Como ele afirma: "Primeiramente, é preciso notar que a mistura não é indiscriminada. Há sistemas que não são aceitos na mistura" (Fiorin, 2009: 121). Vemos, assim, nos trechos abaixo, como os isseis mudam de postura e passam a aceitar a relação de seus filhos com valores brasileiros, mas sempre tentando preservar os valores fundamentais japoneses:

Ainda segundo este autor [Hiroshi Saito], atualmente, talvez como consequência da guerra, os 'issei' mudaram a sua atitude, admitindo que seus filhos são brasileiros, e exigindo deles apenas a manutenção de certos padrões japoneses (Cardoso, 1959: 105).

A família patriarcal japonesa está se dissolvendo como unidade econômica, sob a pressão do processo de urbanização e da preocupação de ascensão social decorrente da situação de imigrantes (Cardoso, 1959: 110).

Além de todas as pressões e conflitos, a permissão para que os filhos saiam da comunidade decorre também da própria percepção dos limites de influência da família japonesa sobre o nissei naquele momento histórico. $\mathrm{O}$ trecho abaixo mostra claramente que a família japonesa não tem condições de ser mais o destinador-manipulador do nissei, ao menos no programa narrativo que visa à ascensão social do filho do imigrante:

Por outro lado, o grupo familial não é capaz de preparar os filhos para os papéis que terão de desempenhar como adultos. A família deseja e incentiva a procura de uma profissão urbana, mas não pode preparar a integração dos jovens à sociedade brasileira, condição necessária ao êxito (Cardoso, 1959: 110).

Inicialmente, o desejo do issei está voltado, como vimos, para tornar o nissei o herdeiro dos valores nipônicos. Contudo, o texto mostra que há um progressivo relaxamento do issei (de pelo menos alguns isseis), motivado pelos 
fatores acima mencionados (pressão da sociedade brasileira, percepção dos limites de influência e desejo de ascensão social do nissei).

O imigrante japonês passa a aceitar que seus filhos busquem um comportamento mais próximo ao de um brasileiro. Sendo o issei o destinadormanipulador do nissei, ele deixa de ser um destinador tenso (intolerante contra os valores estranhos aos da cultura nipônica) para passar a um relaxamento que permite aos seus filhos tomar outro percurso que não aquele constituído na comunidade nipônica. Esse relaxamento não ocorre por um /querer/ próprio do destinador, mas por um /dever/, ou seja, por uma necessidade para a conquista de algo maior e pela pressão externa exercida pela sociedade brasileira, que segrega a comunidade japonesa:

\begin{abstract}
Estamos, pois, diante de uma situação especial, em que os imigrantes japoneses, vivendo os problemas do após-guerra, e em sua grande maioria influenciados pelas opiniões desse jornal [Jornal Paulista] e de líderes do grupo que representa tomaram consciência da marginalidade do 'nissei', daí decorrendo maior tolerância com certas atitudes não conformes com os padrões tradicionais japoneses (Cardoso, 1959: 106).
\end{abstract}

Notamos, por exemplo, que o 'issei' em São Paulo hoje não se opõe a que seus filhos frequentem bailes em suas associações, usem o português quando não estão falando com pessoas idosas, e até mesmo o namoro é tolerado (Cardoso, 1959: 106).

Um índice significativo dessa tolerância é a reação do 'issei' frente às associações de 'nissei', pois esses grêmios, promovendo bailes, oportunidades de namoro, independência das atividades dos filhos com relação aos pais, e mesmo críticas a certas atitudes destes, têm papel relevante na imposição dos novos padrões (Cardoso, 1959: 106).

Ao mesmo tempo em que o issei se torna mais relaxado em relação à aceitação de determinados comportamentos e práticas estranhas à tradição nipônica, o nissei não precisa entrar em confronto direto, em alguns casos, com os padrões valorizados pela comunidade japonesa. Não deixa, assim, de ser certa estratégia do issei para que os valores tradicionais japoneses mais importantes para a família e para a comunidade japonesas sejam preservados, como podemos ver no trecho abaixo:

Parece-nos que tal situação se tornou possível porque os primeiros imigrantes realizaram uma rápida acomodação, o que permitiu ao 'nissei' quase manter o mesmo padrão. A atitude de aceitação, desenvolvida desde os primeiros esforços de ajustamento a uma cultura muito diversa, e aumentada depois da guerra, pela situação particular vivida pelos imigrantes, faz com que os jovens encontrem campo propício para discussão e consequente aceitação daqueles 
comportamentos novos que sentem necessários. Por sua vez, os 'nissei' não precisam quebrar uma grande resistência, podem manter quase as mesmas relações dentro da família, apesar de estarem atuando decididamente para a mudança de certos padrões (Cardoso, 1959: 117).

Podemos representar tensivamente essa transformação do issei e da família japonesa. Inicialmente configurado na posição de um concentrado tônico (que reflete em seu fechamento e sua intolerância em relação ao diferente), o issei e a família japonesa começam a relaxar e a caminhar em direção a um ponto aberto átono, em que há uma aceitação de novos valores e práticas em relação ao nissei:

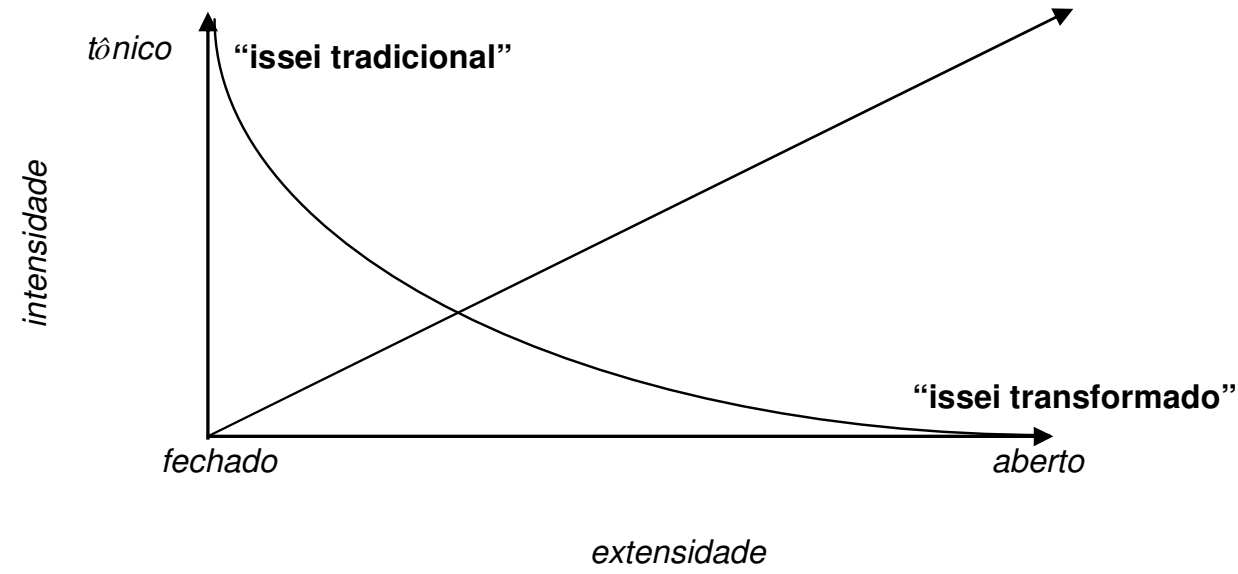

Uma das consequências dessa mudança de postura e de mentalidade do issei se reflete na transformação das associações juvenis. $O$ issei passa a aceitar práticas estranhas à tradição nipônica, como bailes, namoro e, principalmente, a independência dos filhos em relação à família, levando, assim, a uma progressiva mudança de padrões comportamentais nos jovens e na comunidade.

No processo de aculturação do imigrante japonês e de seus descendentes, as escolas brasileiras também têm um papel importante, mas menor do que o das associações juvenis, as quais cabem o papel principal nesse processo. Essa maior importância existe porque as associações juvenis procuram especificamente ensinar aos nisseis os hábitos e os valores brasileiros. Na próxima seção, examinaremos justamente o papel dessas associações. 


\section{Os espaços de sociabilidade como adjuvantes do nissei no processo de aculturação}

Como dissemos acima, a transformação das associações decorre da mudança de postura de parte da comunidade japonesa, mais especificamente dos imigrantes japoneses, por causa do seu isolamento durante a Guerra e por pressões da sociedade e do Estado brasileiros. Veremos, assim, como a associação se transforma em um espaço de auxílio para o filho do imigrante japonês, na medida em que é nesse espaço que ele adquire traços para se tornar brasileiro. Examinaremos, ainda, como esse papel da associação é avaliado pelo enunciador.

O texto de Cardoso mostra que o conceito de associação, enquanto um espaço de sociabilidade, vem do Japão. No período anterior à imigração japonesa, o governo do Japão reorganizou e valorizou as associações juvenis para elas se tornarem um meio de transmissão dos valores nacionais associados ao "espírito militarista" japonês. Dessa maneira, a associação é inicialmente o espaço onde se aprende os valores cívicos japoneses. Esse mesmo "espírito" é trazido junto com a instalação das associações no Brasil:

\footnotetext{
A imigração japonesa no Brasil data deste século, e os imigrantes, trazendo do Japão de pré-guerra aquele espírito militarista, valorizam as associações juvenis a tal ponto que elas apareceram em número bem maior que as associações de senhoras, de velhos, de meninos etc., que também existiam tradicionalmente e que, por sua vez, começaram a surgir no Brasil (Cardoso, 1959: 108).
}

A explicação do grande número de associações em relação à população de 'nissei' pode ser procurada nos incentivos inerentes à cultura japonesa. Tradicionalmente os japoneses se organizam em agrupamentos por idade, com funções definidas, e os 'seinen-kai' ou 'seinen-dan' (agremiação de jovens) foram reorganizados modernamente e aproveitados para a política nacional e militarista dos governos contemporâneos (Cardoso, 1959: 108).

Mesmo tendo uma grande variedade de associações (como a dos meninos, dos idosos e das senhoras), a associação japonesa que predomina 
no Brasil é a dos jovens filhos dos imigrantes ${ }^{129}$. Em alguma medida, esse predomínio da associação juvenil nas colônias japonesas decorre do "espírito militarista" e da ideia de que os jovens estão ainda em formação e, portanto, necessitam da orientação "correta" para assimilar os valores nacionais japoneses.

Mas essa concepção militarista das associações juvenis não perdura muito tempo no Brasil. Ainda durante a Segunda Guerra Mundial, as associações de imigrantes japoneses estabelecidas no Brasil enfrentam mudanças significativas. Essas transformações só são possíveis, segundo o texto, porque o governo de Getúlio Vargas afasta os isseis da direção das associações:

O 'seinen-kai' foi se libertando da tutela do 'issei'. Seus diretores só podiam ser brasileiros; e os filhos de imigrantes, diante do impacto da declaração de guerra ao Japão, tomaram consciência de sua situação particular em razão de sua nacionalidade brasileira, atuando decididamente na direção dos clubes. $O$ 'nissei' pode dar-lhe outra orientação, de certa forma atualizando as suas atividades (Cardoso, 1959: 109) ${ }^{130}$.

Sem a presença de isseis na administração das associações, um forte elo com o Japão é rompido na comunidade japonesa. Dessa forma, não mais sendo dirigidas por imigrantes japoneses, as associações podem se transformar em um espaço mais aberto a outras tradições e práticas pela ação dos nisseis (juridicamente considerados brasileiros).

Foi esse crescente prestígio dos mais jovens que possibilitou o aparecimento de associações juvenis independentes, que se constituíram sem a participação dos 'isseis' ou se libertaram de sua tutela, para defender e dar prestígio ao 'nissei', reunindo todo um grupo com os mesmo problemas e as mesmas necessidades (Cardoso, 1959: 107-108).

Após as mudanças nas diretorias, as associações deixam de ser apenas núcleos de preservação e de transmissão dos valores japoneses. Por um lado, elas se abrem a novas atividades, como jogos de futebol e de beisebol, concurso de beleza e bailes, que correspondem às novas expectativas dos

\footnotetext{
${ }^{129}$ Apresentamos a definição de associação juvenil dada pelo texto: "Sob a rubrica associação de 'nissei' reuniremos clubes e grêmios bastante diversos quanto a sua finalidade, mas que agrupam os jovens 'nissei' em atividades organizadas, propiciando a convivência" (Cardoso, 1959: 108).

${ }^{130}$ Seinen-kai ou seinen-dan é a forma como a associação juvenil é chamada em língua japonesa (Cardoso, 1959: 108).
} 
nisseis. Por outro lado, a associação permanece sendo, em alguma medida, um espaço homogêneo (no sentido de que todos que a frequentam possuem o mesmo problema de adaptação à sociedade brasileira e a mesma busca por outro padrão de comportamento). Consequentemente, esse espaço mais homogêneo se torna mais tranquilo para que os nisseis possam adquirir novas práticas, anteriormente estranhas à comunidade japonesa. Apesar de ser um ambiente mais homogêneo, a associação está no centro de um conflito próprio ao nissei: a definição de sua "verdadeira" nacionalidade.

Conseguida esta independência econômica e enfraquecida a dominação dos 'issei', os 'nissei' transformaram os 'seinen-kan' em clubes recreativos capazes de atender à segunda geração de japoneses num momento em que a consciência de uma definição de nacionalidade se impunha (Cardoso, 1959: 109).

No momento de decisão sobre sua nacionalidade, o nissei é também incentivado a buscar certa integração junto à sociedade brasileira para que ele possa ascender socialmente, como já dissemos. Assim, as associações juvenis $^{131}$ cumprem, no Brasil, a função de integrar os nisseis à sociedade brasileira (Cardoso, 1959: 108). Esse papel integrador das associações juvenis só se torna possível pelas seguintes razões: a) a saída dos isseis da direção das associações; b) a percepção de que a família japonesa não tem possibilidade de oferecer as condições da integração de seus filhos à sociedade brasileira:

A família japonesa, oferecendo, como já vimos, alguns incentivos ao ajustamento, falha como agente integrador; o agrupamento de jovens passa a exercer esta função, reunindo a geração afligida por problemas comuns e tentando oferecer soluções. Com a sua transformação funcional, o 'seinen-kai' tornou-se uma instituição capaz de responder às necessidades de integração dos jovens 'nissei' à sociedade mais ampla (Cardoso, 1959: 110).

Entretanto, se o 'seinen-kai' conseguiu viver e espalhar-se por todas as zonas de população japonesa, foi não só porque os 'issei' o desejavam, mas também porque se tornaram recursos de integração do 'nissei' à sociedade brasileira, adquirindo assim função diversa da original (Cardoso, 1959: 108).

\footnotetext{
131 A autora aponta a existência de dois tipos de associações: os "clubes", com um número maior de associados, em geral constituída por indivíduos recém-chegados do interior, caracterizada por uma diversidade social maior e com o intuito de transmitir novos comportamentos aos seus associados; o outro tipo de associação é a de pequenos grêmios, controlados ainda pelos isseis e que congregaram pessoas da vizinhança (Cardoso, 1959: 109).
} 
[As associações] Funcionam como grupos de idade que procuram a integração do 'nissei', permitindo selecionar e impor certos comportamentos novos (Cardoso, 1959: 109).

A família japonesa tem o desejo de que o nissei se integre à sociedade brasileira para poder mais facilmente ascender na escala social, mas não possui a competência necessária para operar a transformação que resulta na assimilação. Dessa forma, é a associação, enquanto adjuvante, que permite a transformação do nissei ao atribuir a esse sujeito a competência necessária para sua transformação inicial (deixar de ser completamente um japonês para passar a ser um cidadão brasileiro).

É nesse espaço associativo que o nissei pode buscar novos padrões de comportamento e alguns valores diferentes em relação ao que ele conhece e está diretamente ligado à comunidade japonesa. Nos trechos abaixo, vemos claramente o papel de adjuvante que a associação juvenil cumpre em relação ao nissei, sobretudo para atribuir a modalidade do /saber-ser/:

Em todas as associações, encontramos uma consciência muito clara da posição do 'nissei' e da necessidade de educá-lo, de torná-lo capaz da convivência com brasileiros. Principalmente os diretores têm opiniões formadas sobre o assunto e pretendem que os 'clubes' são uma ponte que permite posteriormente a participação do 'nissei' em outros clubes nacionais (Cardoso, 1959: 111).

Em resumo: as associações se caracterizam pela preocupação contínua em criar condições para a ascensão social do 'nissei', i.é., fornecendo-lhe comportamentos e atitudes que lhe permitam conseguir o êxito esperado pela família (Cardoso, 1959: 114).

A admissão do casamento na base do entendimento entre os cônjuges impõe de imediato uma série de inovações para os 'nissei', tais como o namoro como padrão reconhecido, a aceitação do casamento misto, a admissão de convivência entre jovens dos dois sexos. As associações, através de suas atividades, propiciam ocasiões para que tais padrões tenham vigor; e assim, é que pouco a pouco conseguiram impor o baile como forma de recreação apesar da resistência dos 'issei', que, presos às suas tradições culturais (casamento arranjado e não-convivência entre os sexos), não podiam compreendê-lo (Cardoso, 1959: 116).

O trecho abaixo detalha as funções que a associação atribui aos nisseis (baile, uso do português, namoro e casamento não arranjado). Por isso, a associação é um espaço em que essas funções são aprendidas e executadas:

Isto (o que) mostra claramente que nas associações o 'nissei' encontra um grupo homogêneo de convivência, que permite o aprendizado, com um mínimo 
de conflitos, de certos comportamentos que a família, pelas razões já apontadas, não the pode ensinar. Realmente, as associações selecionaram alguns focos de atuação tais como impor o baile como recreação admissível, o uso do português, o namoro e o casamento não arranjado, discutindo estes assuntos e, principalmente, criando condições para que isto se realize normalmente (Cardoso, 1959: 112).

O clube juvenil procura homogeneizar algumas atitudes e formas de comportamento (Cardoso, 1959: 114).

O fato de a associação ser um espaço homogêneo, enquanto um local em que todos os sujeitos possuem os mesmos problemas de falta de competência e buscam igualmente eliminar essa falta, permite ao nissei adquirir certos valores brasileiros de modo tranquilo e sem sobressaltos porque não há a presença de brasileiros $\mathrm{e}$, consequentemente, não existe a possibilidade de ocorrer um conflito com a sociedade brasileira. Assim, todos os sujeitos que frequentam a associação adquirem a mesma competência necessária para o programa narrativo de base (ascensão social). Dessa forma, do ponto de vista dos sujeitos que frequentam a associação, a homogeneidade desse espaço é considerado um aspecto positivo, enquanto a presença de brasileiros é vista como uma heterogeneidade que não ajuda o nissei a adquirir uma nova competência modal.

Em termos semióticos, se a integração à sociedade brasileira é prérequisito para um /fazer/ bem sucedido do sujeito nissei, que visa a entrar em conjunção com seu objeto de valor (a ascensão social), a associação juvenil é um adjuvante que auxilia o sujeito a adquirir um /saber-ser/ para seu/saberfazer/. Em outras palavras, as associações se organizam modalmente por um /fazer-saber-ser/ que conduz o nissei a um /saber-fazer/:

Tal situação cria para as associações uma função específica: abrasileirar o 'nissei', fornecendo-lhe pelo menos padrões de comportamento adequados. É desta maneira que estão agindo os 'clubes', permitindo e valorizando condutas outrora vedadas ao 'nissei', tais como: dançar, participar de festas ocidentais, concurso de beleza etc. $\mathrm{E}$, mais ainda, dando-lhe um núcleo de convivência em que se usa apenas a língua portuguesa, cujo domínio é condição importante para o sucesso nos cursos escolares e na vida profissional (Cardoso, 1959: 110).

Nesse trecho, o programa narrativo de uso, cujo adjuvante é figurativizado pelas associações, recebe os seguintes investimentos semânticos: dançar, participar de festas ocidentais, concursos de beleza, uso 
da língua portuguesa. Em outras palavras, a associação doa ao filho de imigrantes japoneses o que lhe falta para desempenhar bem certas atividades atreladas à convivência com os brasileiros. Dessa forma, para alcançar a condição de sujeito bem sucedido, o nissei deve percorrer esse novo programa de uso, com a adesão a novos valores e a uma outra língua. A língua portuguesa é, segundo o texto, a condição fundamental para o sucesso do nissei. Dominar o seu uso é, assim, considerado necessário para conquistar espaço no trabalho e progredir socialmente.

Progressivamente, o nissei deve se tornar cada vez menos japonês e, consequentemente, cada vez mais brasileiro a partir da aquisição de elementos estranhos à comunidade japonesa, sobretudo em seus aspectos culturais. A instância que faz essa transformação é, como já está mais do que claro, atributo da associação, que faz o nissei saber ser mais brasileiro e menos japonês. Esquematicamente, podemos propor a seguinte representação da função das associações juvenis:

\begin{tabular}{|c|c|}
\hline PN de base da comunidade japonesa & PN de base da sociedade brasileira \\
\hline Família/Escola da colônia japonesa & Escola brasileira/Trabalho \\
\hline \multicolumn{2}{|c|}{ Associação juvenil } \\
(programa de uso) \\
\hline
\end{tabular}

No entanto, a função de adjuvante não é completamente aceita na comunidade japonesa, tanto por isseis como por alguns nisseis. Essa falta de unanimidade em relação às associações se deve a diferentes percepções e opiniões sobre os limites de influência sobre a formação dos valores dos filhos dos imigrantes. Muitos nisseis acreditam que as associações juvenis são, na realidade, núcleos segregadores que mantêm os nisseis distantes da sociedade brasileira, como vemos abaixo:

"Dentro da colônia japonesa, já se esboçou uma crítica a esta tendência [de que a associação juvenil pode ser uma ponte para clubes brasileiros de prestígio]. A página em português do Jornal Paulista foi o veículo dessas opiniões, que muitas vezes apareceram em artigos violentos. Afirmam os redatores dessa página que as associações são órgãos segregativos, que, isolando o 'nissei', permitem que ele mantenha certas ligações com a colônia 
movido por possíveis vantagens políticas ou profissionais. Insistem os críticos em que o filho de japoneses é brasileiro e deve agir sempre como tal, vivendo os problemas nacionais, e não limitar-se aos da colônia" (Cardoso, 1959: 111).

"Os redatores desta parte em português do jornal mantém ainda esta posição extremada. Chegaram mesmo a realizar mesas-redondas com os diretores de clubes, defendendo a ideia de sua extinção ou transformação, para que o 'nissei' enfrente o convívio com os brasileiros em lugar de se isolar" (Cardoso, 1959: 112).

Parte desses nisseis sanciona negativamente a existência das associações. Eles consideram a associação como um espaço segregativo porque não há uma interação efetiva com brasileiros. Esses críticos, principalmente no Jornal Paulista, desejam uma abertura efetiva da colônia e, sobretudo, do nissei, que deve se comportar como brasileiro e enfrentar os problemas comuns a todos os brasileiros. Esses críticos das associações desejam uma maior abertura da comunidade à sociedade brasileira. Dessa forma, esses nisseis críticos acreditam que todo nissei deve portar o papel temático de "cidadão brasileiro" e não apenas o do "cidadão japonês" (como quer a comunidade japonesa) ou mesmo o papel de "sujeito bem sucedido" (desejo de boa parte das famílias japonesas).

Esse desejo por uma maior abertura ou mesmo a extinção da associação (sanção de alguns nisseis) também é encontrado no próprio enunciador, que apresenta a seguinte sanção sobre a associação juvenil:

\footnotetext{
$\mathrm{Na}$ verdade, todos os clubes desejam manter-se como grupo isolado, e desejam a participação apenas de 'nisseis'. Encontram para esta situação justificativas várias; mas, na verdade, o prestígio da associação aos olhos do 'issei' estaria em perigo se ela fosse mais aberta. O seu trabalho de abrasileirar o 'nissei' só é possível se contar com a aprovação dos 'issei', e, como já vimos atrás, esta aprovação existe atualmente" (Cardoso, 1959: 112).

"Não se pode esquecer, porém, que esses grêmios recreativos são núcleos de segregação. Aí só convivem 'nissei', impedindo um maior contacto destes com jovens de outras origens (Cardoso, 1959: 119).
}

Os dois fragmentos acima são formas de uma sanção negativa sobre as associações porque elas se mantêm isoladas e permitem apenas a presença de nisseis em suas atividades. O ponto de vista dessa sanção é ainda reforçado por meio de uma modalização veridictória ("na verdade"). Essa modalização deixa pressuposta a ideia de que outros discursos acreditam que 
as associações juvenis sejam elementos realmente integradores do nissei à sociedade brasileira.

A posição segregativa das associações permanece, segundo o texto, porque elas são ainda manipuladas e sancionadas pelos isseis ("o seu trabalho de abrasileirar o 'nissei' só é possível se contar com a aprovação dos 'issei', e, como já vimos atrás, esta aprovação existe atualmente"). Segundo o texto, os isseis não perderam seu prestígio dentro da comunidade, mesmo afastados da direção das associações.

De qualquer forma, segundo Cardoso, a posição segregada da associação juvenil permite ao nissei adquirir com maior tranquilidade os valores brasileiros. Em seguida, já revestido com essa competência, o nissei passa a se confrontar com a sociedade brasileira, na medida em que participa de seu programa narrativo de base. É a partir daí que ele chega ao ponto de tomar a decisão sobre qual caminho seguir: voltar-se para os valores da colônia japonesa ou partir em direção ao programa narrativo da sociedade brasileira, na qual ele pode tentar ascender socialmente.

Procuramos no decorrer do trabalho apontar as razões disto [isolamento da associação juvenil] e devemos indicar que se essa forma de segregação permite à associação ser um agente positivo de aculturação, ela se cria depois que o adolescente, passando por experiências críticas de ajustamento à vida urbana, sente necessidade de um isolamento para refazer suas opiniões e torná-las vigentes. Compreendida assim a ação dos jovens, vemos que o clube não se opõe à escola ou a outros agentes aculturativos; apenas permite a renovação da experiência que a nova geração vai vivendo ao se afastar cada vez mais da família (Cardoso, 1959: 119).

Essa questão de decidir qual o caminho tomar (voltar-se para a colônia japonesa ou encarar a sociedade brasileira) ocorre também quando o nissei está na escola brasileira. Segundo Cardoso, a escola brasileira é também outro agente importante no processo de aculturação dos descendentes de imigrantes japoneses. Contudo, como o contato com brasileiros é mais frequente, o nissei se sente segregado e, por essa razão, ele é levado a voltar-se para a comunidade japonesa:

Evidentemente, não se pretende negar o papel desempenhado pela escola na aculturação dos 'nissei'. Basta lembrar a exigência do uso continuo e fluente do português, para que não se esqueça sua importância, mas a ação que ela exerce é paralela à de outras instituições e situações em que vive o adolescente, e que vão exigir do jovem uma definição de atitude. É aí que 
emerge neste a consciência de sua posição marginal e então o 'nissei' reage, como vimos, desenvolvendo maior lealdade à colônia, mas ao mesmo tempo dispondo-se a renovar suas atitudes e lutar por esta renovação (Cardoso, 1959: 120).

A escola brasileira não deixa de ser também um adjuvante do programa narrativo de uso do sujeito nissei. A diferença é que, enquanto a família e a associação juvenil estão do lado do programa narrativo da comunidade japonesa, a escola brasileira está, evidentemente, do lado do programa narrativo da sociedade e do Estado brasileiros, como vimos anteriormente. Além disso, o próprio enunciador reconhece que a influência da escola na aculturação dos nisseis possui limitações temporais: mais tempo vivendo na colônia diminui a possibilidade de o nissei se tornar brasileiro; menos tempo na escola brasileira aumentam as chances dele prosseguir como um sujeito japonês.

O fragmento acima mostra que o desejo dos nisseis pela integração não é tão evidente assim, principalmente quando há a percepção de sua condição diferenciada (realçada na escola brasileira em que estão em contato com brasileiros). Assim, os nisseis têm a tendência a desenvolver maior "lealdade à colônia", ou seja, eles se voltam para os valores da colônia japonesa quando em contato com brasileiros. Além disso, a diferença e a diversidade da escola são vistas de modo negativo pelo nissei, já que ele se sente "marginalizado" nesse espaço. Por tudo o que foi visto rapidamente sobre o nissei em sua relação com os espaços de aculturação (associações e escola), podemos dizer que há, ao menos, dois tipos de nissei: o que deseja uma grande abertura e aquele que se volta para os valores tradicionais japoneses.

Vimos, nesta seção, que a associação juvenil dos imigrantes japoneses passou por transformações, derivadas da pressão da sociedade brasileira e da percepção do próprio issei em relação aos seus limites de influência sobre o nissei. A principal consequência dessa transformação é a abertura da associação para outras práticas e valores, inicialmente estranhos à comunidade japonesa, como uma forma de o nissei adquirir alguns elementos considerados específicos da sociedade brasileira para, a partir daí, poder realizar seu desejo de ascender socialmente. 
Em certa medida, a associação permanece segregada do restante da sociedade brasileira para permitir ao nissei a aquisição dos traços e valores brasileiros com uma relativa tranquilidade, uma vez que a presença de brasileiros é praticamente inexistente e pode representar uma ameaça ao processo de aculturação dos filhos dos imigrantes japoneses. Dessa forma, a associação é um espaço no qual o nissei passa por um "estágio" para em seguida por em prática o que aprendeu na associação ao interagir com a sociedade brasileira. Como mencionamos rapidamente nesta seção, o nissei também passa por diferentes transformações no espaço da associação. Prosseguiremos examinando justamente como o texto constrói a imagem dos nisseis, assim como a sanção que é aplicada a esse sujeito pelo enunciador.

\section{A imagem dos nisseis, sua transformação e seus reflexos}

O nissei, foco do trabalho de Ruth Cardoso, não está alheio às transformações pelas quais $\mathrm{o}$ issei e as associações passam no momento seguinte ao final da Segunda Guerra Mundial. Como foi dito acima, o nissei é, inicialmente, considerado o herdeiro da tradição e dos valores japoneses em solo brasileiro. No entanto, com a pressão da sociedade brasileira pela assimilação e os conflitos existentes no seio da comunidade japonesa, esse papel de herdeiro da tradição é revisto pelos isseis. Veremos, nesta seção, como ocorre a transformação do comportamento e dos valores do nissei e a sanção aplicada pela antropóloga sobre o filho do imigrante japonês.

Como todo objeto de pesquisa, sobretudo quando envolvidas as dimensões histórica e social, o nissei apresenta diferentes facetas e características. Assim, por baixo de uma mesma alcunha, é possível observar sujeitos com uma maior ou uma menor proximidade com a comunidade japonesa. Por exemplo, o estudo de Ruth Cardoso menciona a existência de nisseis que não participam das associações juvenis. Esses nisseis ficam somente no programa narrativo da família japonesa, como vemos abaixo:

Entre os adolescentes que não frequentam esses núcleos, percebemos uma ligação muito mais intensa com a família e uma submissão maior aos pais. Em tais condições, a escola não pode atuar eficiente e decisivamente como agente aculturativo, pois a sua ação se limita aos períodos de aula, e mesmo a 
comunicação entre os alunos é restrita. Não há condições para que as crianças ou os jovens renovem suas atitudes a partir dos contactos esporádicos que a escola brasileira impõe (Cardoso, 1959: 119-120).

Esse trecho mostra a lógica do "quanto mais próximo da família, menor a possibilidade de aculturação". Dessa forma, um adjuvante como a escola brasileira não é forte o suficiente para a aculturação do nissei pelas razões já vistas. Essa limitação de influência da escola brasileira sobre o filho do imigrante japonês decorre do pouco tempo de contato com alunos brasileiros, além da própria proximidade do nissei em relação à sua família.

Mas esse é apenas um dos casos vividos na colônia japonesa. De um modo geral, segundo o texto, o nissei é manipulado (por meio da intimidação e da tentação) pela família para ser membro da comunidade japonesa e, ao mesmo tempo, para buscar sua ascensão social fora da colônia, como já destacamos anteriormente:

O que interessa ressaltar, porém, é a dupla orientação que tem o 'nissei' mesmo dentro da sua família: pressão para tornar-se um membro da comunidade japonesa e, ao mesmo tempo, expectativa de que através de uma formação profissional consiga ascender na escala social (Cardoso, 1959: 104).

O importante a reter nesse trecho é que o nissei, a despeito de incentivos para buscar sua ascensão social, não sai completamente da área de influência da comunidade japonesa. Ele precisa sair da colônia japonesa para poder estudar e trabalhar, mas deve permanecer membro da comunidade e preservar os valores nipônicos. Por isso, o papel da associação é fundamental para essa passagem de programas narrativos, como foi mostrado na seção anterior, uma vez que é na associação que o nissei se acultura, ou seja, adquire valores e práticas da sociedade brasileira.

Vemos que os valores engendrados pelo discurso de Ruth Cardoso, por meio dos trechos abaixo, mostram como a aculturação é necessária para o sucesso do nissei. Mas o nissei não pode se limitar a frequentar a associação. Ele precisa ainda participar diretamente do programa narrativo da sociedade brasileira para alcançar seu objeto-valor e, assim, ser reconhecido como um sujeito bem sucedido. Portanto, se a aculturação é, quase automaticamente, a condição necessária para o sucesso do filho do imigrante japonês, pode-se então dizer que a aculturação é um valor positivo ou eufórico nesse discurso, 
seja do ponto de vista dos imigrantes e de seus filhos, seja da perspectiva do enunciador.

Porém, pela sua formação e para que possa gozar de certos direitos, deve o 'nissei' viver como brasileiro, e a escola, os amigos, a sua iniciativa pessoal entre outras 'virtudes ocidentais' é que Ihe vão garantir sucesso e prestígio, mesmo dentro do grupo de imigrantes (Cardoso, 1959: 107).

O êxito profissional dos jovens, que é uma meta na educação familiar do 'nissei', depende desta integração aos ideais de comportamento da sociedade brasileira; para possibilitá-la, as associações oferecem aos 'nissei' oportunidades para se adaptarem a seus papéis ocidentais (Cardoso, 1959: 110).

Os indivíduos de maior prestígio nos clubes são os que obtiveram êxito fora da colônia e que são capazes de viver entre brasileiros facilmente (Cardoso, 1959: 119).

O nissei deve, então, "viver como brasileiro". Para ser reconhecido como brasileiro, ele deve apresentar elementos identificados como "virtudes ocidentais", tais como ter amigos (brasileiros), iniciativa pessoal e frequentar a escola (brasileira). São esses traços que vão levar o nissei a ser reconhecido como um sujeito bem sucedido ("sucesso e prestígio") segundo o enunciador. Por isso, para alcançar o status social, o nissei deve ter os "ideais de comportamento da sociedade brasileira", ou seja, mostrar que consegue viver como um brasileiro e, por conseguinte, "viver entre brasileiros facilmente". Essas características do nissei aculturado (e, mais do que isso, assimilado) são sancionadas positivamente pelo enunciador, que parece desejar ao nissei que ele viva plenamente os "papéis ocidentais" de supostamente todo e qualquer brasileiro.

Por isso, é possível dizer que o nissei vive em dois mundos, mas não exatamente entre a família nipônica e a sociedade brasileira. O enunciador mostra, no trecho abaixo, que a ideia desses dois polos nos quais o nissei viveria é um equívoco. Parte do artigo procura, justamente, desfazer esse equívoco:

Não podemos, entretanto, caracterizar tão simplesmente a situação, admitindo dois pólos opostos: a família japonesa e a sociedade brasileira. Mesmo dentro de sua família, encontra o 'nissei' estímulos para um entrosamento no meio brasileiro, que se traduz principalmente por uma exigência de êxito profissional. Como todo imigrante, o japonês pretende uma rápida ascensão, e espera dos filhos sucesso econômico ou adoção de uma carreira que Ihe garanta 'status' mais elevado. Esta expectativa exige um relativo entrosamento dos jovens à 
sociedade brasileira, levando o 'issei' a aprovar e admitir um círculo de convivência, fora da família, em que age como brasileiro (Cardoso, 1959: 104).

A tolerância na família japonesa, que parece ter começado depois da guerra, indica que o 'nissei' não vive em dois mundos diversos, a sua família e os grupos brasileiros que frequenta. Profundamente atingidos pelo processo aculturativo, os padrões de comportamento familial japoneses não apresentam mais a antiga coerência; assim, os jovens ficam colocados entre dois pólos de influencias, que, porém, não podem ser identificados com a família e os grupos brasileiros, representados especialmente pela escola, como se tem pensado até agora (Cardoso, 1959: 107).

O fragmento acima nos mostra que o nissei cumpre ao mesmo tempo dois programas narrativos distintos: um próprio da colônia, que se isola e preserva seus valores mais tradicionais e está localizado no campo; e outro, que ocorre no espaço da associação, que, em geral, está presente na cidade. Em outras palavras, o nissei encontra no ambiente familiar incentivos para estudar, trabalhar e ascender socialmente, sem contudo perder o contato com comunidade. Mas, para alcançar o objetivo de melhorar de vida, o nissei precisa obrigatoriamente entrar em contato com o "lado brasileiro".

É justamente no espaço brasileiro que o nissei encontra as maiores dificuldades para alcançar seu objeto-valor. Os trechos a seguir mostram a necessidade de um grande esforço do nissei para conseguir se adaptar à vida na cidade:

De qualquer forma, já bem cedo certos problemas se colocam ao 'nissei': o aprendizado do português, o ajustamento a um regime escolar diverso, a convivência com colegas e amigos. Desde então, ele começa a viver em dois ambientes distintos (Cardoso, 1959: 104).

O entrosamento do 'nissei' à vida urbana exige dele um grande esforço, porque o adolescente recém-saído de uma família de camponeses tradicionais e herdeiro de padrões culturais estranhos, deve vencer muitas barreiras até que possa ajustar-se convenientemente a certas condições rotineiras da vida urbana (Cardoso, 1959:110).

Entre o 'nissei' que vem do interior é que parece haver os com maior potencialidade para se urbanizarem e com maior consciência dos problemas de contacto, porque o jovem que migra sozinho, devendo enfrentar a cidade grande e ajustar-se a ela, sente melhor os obstáculos decorrentes de sua condição de 'nissei' (Cardoso, 1959: 115).

Os antissujeitos presentes no trecho acima estão relacionados tanto ao /saber-fazer/ (o aprendizado e, principalmente, o uso da língua portuguesa) como ao /saber-ser/ (em sua relação com colegas e amigos e em novos 
ambientes sociais). Além disso, vemos nos trechos acima, que esse contato do nissei no espaço social brasileiro é feito em termos de ajustamento. A consequência disso é que o filho do imigrante japonês deve se adaptar a um universo de sentidos diferente do que está acostumado. Essa adaptação ocorre por meio de todo um processo e não como uma forma de conjunção completa e definitiva do nissei às práticas e aos valores brasileiros. Além do mais, esse ajustamento é feito apenas do lado do filho dos imigrantes japoneses, ou seja, cabe somente a ele se adaptar às condições da sociedade brasileira (e nunca o contrário).

Dessa forma, na tipologia de sujeitos representativos do estilo de vida da alteridade de Landowski, o nissei, nesse discurso, se aproxima da figura do sujeito da admissão, isto é, o sujeito da não-disjunção que, por essa condição, está sempre circulando em universos de valores distintos e programas narrativos diversos, adaptando-se sempre para obter uma conjunção, mesmo que provisória. Boa parte do estudo de Ruth Cardoso mostra, justamente, as dificuldades do nissei em viver nesses "dois mundos".

Por conta da situação de não estar em apenas um único universo social de sentidos, o nissei encontra-se em uma espécie de conflito em sua modalidade do /ser/. Um exemplo desse "conflito" em que vive o nissei está ligado à aquisição de novas opiniões a respeito das relações sociais e dos valores necessários para ele participar de uma nova vida social com brasileiros. $\mathrm{Na}$ associação, a formação das opiniões, muitas vezes novas, não é completamente aceita pelos nisseis. Em outras palavras, o nissei ainda se sente como o portador da tradição japonesa e acaba não lidando bem com novas opiniões, contrárias aos valores em que ele acredita. Por isso, o nissei adquire essas novas opiniões e mesmo as expressa, mas nem sempre para serem aplicadas à sua própria vida:

Porém, nesse abrasileiramento aparente do 'nissei' não se pretende cortar as ligações deste com a colônia, mas aumentar o prestígio dele aos olhos dos 'isseis', com vistas a maiores facilidades para a vida profissional. Em geral, os profissionais liberais começam suas atividades em firmas de japoneses ou contando com clientela certa na colônia. Mesmo os que conseguiram um desligamento bastante grande começaram a vida profissional com a vantagem de contar com um grupo solidário (Cardoso, 1959: 114).

E é aí [perceber as dificuldades de adaptação por ser nissei] que desenvolve atitudes de lealdade para com o grupo de origem, ao mesmo tempo que é 
obrigado a uma revisão de certos comportamentos, que deverão ser abandonados. Note-se que os diretores das associações são, em sua maioria, escolhidos entre os que vieram para São Paulo adolescentes para frequentar cursos superiores ou preparar-se para isto (Cardoso, 1959: 115).

Este trecho de entrevista mostra duas coisas: $1^{\circ}$.) a mudança de atitudes a partir das necessidades criadas pela vida em São Paulo; 2․) o papel do clube na formação de opiniões e na valorização de certos aspectos da conduta ligados à colônias japonesas, tais como a língua, o respeito à família etc. (Cardoso, 1959: 115).

Encontramos, pois, atualmente, uma situação especial, em que os jovens, premidos pela necessidade de ajustamento a uma nova categoria de idade, procuram as associações para aí reorganizar suas opiniões, e, a partir de certos comportamentos que a situação de vida urbana exige, são obrigados a admitir como válidos muitos outros que não estão dispostos a aceitar para si. De qualquer maneira, isto impede que continuem a existir, ao menos como padrão ideal, restrições a casais em que um dos cônjuges não é japonês ou descendente de japoneses, o que facilitará este tipo de casamento (Cardoso, 1959: 116).

É bem verdade que, em grande parte, os alunos entrevistados aprovam o casamento misto, mas não para si mesmos, isto é, não enfrentariam a sua família tentando quebrar os padrões tradicionais. Mas a importância dessa opinião está mais no fato de ser uma nova racionalização da situação de contacto, em que os limites da colônia não são os da convivência (Cardoso, 1959: 116).

Pressionado pelo /dever-ser/ ao mesmo tempo japonês e brasileiro, o nissei reorganiza seus valores e suas opiniões. Ele passa, então, a admitir certas práticas sociais que lhe são estranhas, pois não fazem parte dos valores tradicionais japoneses. Um claro exemplo disso está no casamento com indivíduos de fora da comunidade japonesa. Mas a mudança de opinião não significa a adoção de novos padrões para si mesmo ("são obrigados a admitir como válidos muitos outros [comportamentos] que não estão dispostos a aceitar para si").

Pelos trechos acima, podemos observar que o conflito do nissei passa pela questão do /parecer/ e do /ser/. Assim, ele expressa publicamente uma opinião que é considerada de ampla aceitação pela sociedade brasileira, mas, em seu íntimo, não acredita nessa opinião e não a pratica em sua própria vida. O nissei mantém, assim, uma postura de conveniência em relação ao que a sociedade brasileira espera dele em termos de valores. Por estar em dois universos sociais e culturais distintos, o nissei precisa adaptar-se aos dois contextos (japonês e brasileiro) em um verdadeiro jogo identitário. Podemos dizer, assim, que o nissei sincretiza as duas posturas distintas (a japonesa e a brasileira). Esquematicamente, temos a seguinte representação: 


\begin{tabular}{|c|c|}
\hline Contexto da colônia japonesa & Contexto da sociedade brasileira \\
\hline Opiniões tradicionais & Opiniões novas \\
\hline Valores tradicionais japoneses & Valores novos brasileiros \\
\hline Mais conservador em suas opiniões & Mais liberal em suas opiniões sobre \\
para si mesmo & outros nisseis \\
\hline $\begin{array}{c}\text { Não aceita o casamento com } \\
\text { brasileiro(a) e acredita na } \\
\text { conservação dos valores nipônicos }\end{array}$ & assimilação integral, etc. \\
\hline
\end{tabular}

É dessa forma que o nissei mostra a sua aculturação: veiculando uma opinião aceita pela sociedade brasileira, mas não tão bem vista pela comunidade japonesa. Em outras palavras, o nissei parece estar se aculturando por aceitar e emitir opiniões típicas da sociedade brasileira, mas ele continua sendo portador e defensor dos valores tradicionais japoneses.

Por isso, mesmo participando do programa narrativo da sociedade brasileira, o nissei não deixou de reconhecer o issei como seu destinador ("não enfrentariam a sua família tentando quebrar os padrões tradicionais"). Logo, os filhos dos imigrantes não deixam de ser manipulados pelos isseis, como podemos observar no seguinte trecho:

[O nissei] Aceita a valorização da etiqueta japonesa, do domínio sobre si mesmo, da submissão aos mais velhos, e considera-se na obrigação de viver conforme estas expectativas, porque o seu próprio sucesso depende principalmente da colônia e das oportunidades que através dela lhe forem concedidas como profissional. $\mathrm{O}$ seu êxito é medido dentro e com relação à colônia japonesa (Cardoso, 1959: 107).

Podemos inferir que ao menos parte dos filhos dos imigrantes japoneses adquire os valores nacionais apenas de modo superficial para poder realizar sua busca pela ascensão social sem necessariamente renegar os valores da colônia e da família japonesa.

O enunciador realiza, ainda, uma sanção que desvela a relação dos nisseis participantes da associação com a comunidade nipônica ("abrasileiramento aparente do 'nissei' não se pretende cortar as ligações deste 
com a colônia"). Dessa feita, o enunciador mostra que a comunidade continua a ser o destinador, ou seja, o depósito dos valores dos nisseis:

O 'nissei', consciente de sua posição marginal, define-se como membro de um grupo isolado e nunca se identifica com os brasileiros (Cardoso, 1959: 107).

Por outro lado, os líderes dos jovens não perderam ainda de vista a colônia japonesa, e toda a sua ação tem em mira o seu grupo de origem e não a sociedade mais ampla (Cardoso, 1959: 112).

Por sua vez, os jovens muitas vezes lamentam o desaparecimento crescente da obediência aos mais velhos, louvando-a como costume dos mais belos da família japonesa (Cardoso, 1959: 117).

A sanção realizada pelo enunciador recai principalmente no programa narrativo de uso (o da aquisição de valores brasileiros) e não exatamente no programa narrativo de base (o de ascensão social, o de 'status'). Outra razão para o não abandono dos valores nipônicos e a aquisição completa dos valores brasileiros está descrita no trecho abaixo. O discurso mostra, assim, que o nissei quer se manter segregado porque sabe que é racialmente superior aos brasileiros:

O 'nissei' ainda se pensa como um membro da colônia japonesa, consciente de seus limites e de sua superioridade racial, e não sente as barreiras que existem à miscigenação, porque ele próprio não deseja quebrá-las (Cardoso, 1959: 118).

Entendemos que há uma sanção negativa porque o nissei cumpre o contrato proposto pelos isseis e porque ele não quer cumprir o contrato da integração à sociedade brasileira. Pela sanção, a assimilação não é realizada porque o nissei se considera um sujeito superior, ou seja, como um sujeito que deseja manter-se excluído, em disjunção com aqueles que são diferentes dele e de seu grupo. Ele só se torna um sujeito da admissão para poder ascender socialmente, como vimos.

A discussão feita a respeito desse sentimento passa pela relação entre o /crer/ e o /saber/ no discurso de Ruth Cardoso. Observa-se que, a despeito de uma lacuna na construção do saber, há ainda uma tentativa associar a postura auto segregativa do imigrante japonês e de seu filho a esse sentimento de "superioridade racial": 
Para compreendermos bem a tentativa de ascensão em todos os seus aspectos, seria necessário verificar o significado dos traços raciais nesse processo (Cardoso, 1959: 117).

Infelizmente ainda não temos dados para discutir mais pormenorizadamente o problema, mas pudemos perceber que os japoneses têm uma clara consciência de sua superioridade racial, mito que decorre da educação militarista recebida no Japão. Isto leva facilmente ao isolamento e à segregação; e somando-se os obstáculos que se apresentam ao "nissei" quando este pretende um contacto mais aberto com os brasileiros, compreendemos a facilidade com que se isolam nessas sociedades e por que, na verdade, há pouca vontade de quebrar o isolamento (Cardoso, 1959: 118).

Vemos acima que a questão do sentimento de "superioridade racial" do imigrante japonês e de seus filhos não encontra qualquer tipo de base no conhecimento científico do enunciador. Ao revelar que não há "dados" para comprovar esse sentimento, o enunciador passa para o regime do "perceber" e, por consequência, o reconhecimento de que se trata de um "mito" gerado pela "educação militarista" do japonês e que permanece nos nisseis, segundo seu estudo. Dessa forma, o enunciador passa para o regime do /crer-saber/, cujo resultado imediato é a reprodução de um estereótipo que, como tal, já está cristalizado em seu tempo.

Baseados em Greimas, podemos dizer que o ato epistêmico baseado no /crer/ leva a uma /fazer-interpretativo/ do enunciador sobre o seu objeto. Tratase do que em semiótica se chama de "certeza" (Greimas, 1983: 118; 121): nesse caso, é a certeza de que o imigrante japonês e seu filho se sentem racialmente superiores, mesmo sem o respaldo de todo o percurso do /saber/ que o enunciador vinha utilizando para construir o seu objeto de estudo.

Dessa forma, independente de todas as suas explicações e descrições a respeito das transformações pelas quais todos os membros da comunidade japonesa estão passando, o enunciador afirma que 0 isolamento dessa comunidade está baseado em um sentimento de superioridade racial, mesmo sem qualquer prova ou demonstração (ocorre, justamente, o contrário: o enunciador deixa claro que não foi possível pesquisar a "dimensão racial" da comunidade japonesa).

Pode-se entender isso como um preconceito pela declarada falta de conhecimento suficiente sobre o sentimento dos imigrantes japoneses e seus filhos. De qualquer forma, compreendemos que esse possível preconceito não 
interfere, de modo significativo, no estudo das complexas relações dos imigrantes japoneses, seus filhos e a sociedade brasileira.

Nesta seção, vimos como o nissei vive sob a pressão de alcançar a ascensão social e, ao mesmo tempo, de manter os valores tradicionais da colônia japonesa. De um modo geral, é por meio do contato com brasileiros que o nissei volta-se para a comunidade japonesa, pois muitas vezes se sente marginalizado por sua condição mesma de descendente de japoneses e, em menor medida, pelas dificuldades de viver diretamente em contato com a sociedade brasileira. Nesse movimento de voltar-se à comunidade japonesa, o nissei acaba sofrendo uma sanção negativa por parte do enunciador, uma vez que há uma quebra de expectativa quanto à aculturação e à assimilação do nissei.

\section{Considerações parciais}

Vimos em nossa análise a transformação dos três atores principais do processo imigratório japonês: o issei, o nissei e a associação juvenil. Basicamente, a transformação do issei e da associação se refere a uma maior abertura em direção à sociedade brasileira. Em relação ao nissei, foco central do estudo de Ruth Cardoso, podemos observar algumas características gerais sobre sua possibilidade de transformação:

1) Um programa narrativo de uso que se refere ao aprendizado de comportamentos brasileiros por parte dos nisseis;

2) Um programa narrativo de base do nissei que quer entrar em conjunção com o objeto valor "ascensão social";

3) Um programa narrativo de base do nissei que mantém a comunidade nipônica como seu destinador.

Por fim, a autora atribui a autoexclusão dos imigrantes japoneses e seus descendentes à crença de que eles se sentiam racialmente superiores em relação aos brasileiros. Após 50 anos de imigração japonesa no Brasil, o discurso analisado recupera assim, temas que aparecem em discursos antinipônicos anteriores às Grandes Guerras: o do isolamento, do "espírito" militarista e da superioridade racial dos japoneses. Mesmo sem qualquer outra referência, a autora aponta o sentimento de superioridade dos japoneses, 
retomando as críticas já feitas aos imigrantes japoneses em décadas passadas. É nesse momento, como mostramos, que o discurso de Cardoso deixa de ser um discurso do /saber/ para passar a ser regido pelo /crer/ do enunciador.

De qualquer forma, essa ênfase dada ao "sentimento de superioridade racial e cultural" (citada em três momentos no estudo de Ruth Cardoso) não significa, necessariamente, que a autora tem algum tipo de preconceito explícito contra o imigrante japonês e seus filhos. Prova disso está na descrição das dificuldades que $\mathrm{o}$ nissei tem de adquirir hábitos $\mathrm{e}$ comportamentos da sociedade brasileira por causa de seu duplo pertencimento: a colônia japonesa, de um lado, e a sociedade brasileira, de outro. Além disso, seu estudo mostra como toda a comunidade japonesa (e mesmo as associações juvenis) passa por uma grande transformação após o final da Segunda Guerra Mundial, em um "jogo de forças" tradicionais e inovadoras entre os diversos membros da colônia (imigrantes e descendentes que querem mudanças e outros que desejam a permanência das tradições japonesas).

Estudos sobre a imigração japonesa continuam sendo feitos depois da década de 1950. Junto a esses estudos, o tema "raça" continua presente como uma forma de se pensar nessa imigração especificamente, mas também na imigração de outros grupos. Veremos a seguir como o texto de Reis, publicado em 1961, trata dessa questão, associando-a à assimilação dos imigrantes no Brasil.

\subsection{A persistência da noção de raça e de assimilação na década de $\mathbf{1 9 6 0}$}

\section{Introdução}

Depois de mais de quinze anos do final da Segunda Guerra Mundial e da retomada do processo imigratório no Brasil, as discussões em torno da imigração perdem um pouco de sua presença no espaço político. De toda maneira, a entrada de imigrantes continua existindo na década de 1960, com uma progressiva mudança do perfil dos imigrantes: de um lado, imigrantes europeus de formação profissional mais alta, de outro lado, imigrantes latino- 
americanos e asiáticos (chineses e coreanos) que chegam para ocupar postos que demandam baixa qualificação.

Mesmo com essas mudanças, os estudos sociológicos e antropológicos realizados naquela década ainda estão mais ligados a uma perspectiva diacrônica. Em outras palavras, pesquisadores da área de Ciências Sociais continuam a se debruçar sobre os grupos imigratórios mais tradicionais e ideias como as de raça e assimilação continuam presentes em publicações voltadas para a comunidade acadêmica.

Um claro exemplo dessas características está no texto "Algumas considerações sobre a imigração no Brasil”, publicado na revista Sociologia em 1961. Esse texto, de autoria de P. Pereira dos Reis, trata dos aspectos gerais da imigração no Brasil e, em sua parte final, da imigração japonesa.

Em alguns aspectos, o texto de Reis se aproxima do texto de Côrtes, analisado na primeira parte deste capítulo. Reis, por exemplo, apresenta propostas para a política imigratória brasileira (apesar de não chegar ao nível de detalhamento do texto de Côrtes), além de mencionar também o papel dos migrantes nacionais no processo de assimilação do estrangeiro. Obviamente, essa aproximação é seguida também por algumas diferenças que serão analisadas.

O artigo de Reis pode ser dividido em duas partes, a partir dos efeitos de sentido que cada uma carrega: a primeira, caracterizada por um efeito de sentido mais objetivo, produzido por meio da apresentação de fatos sobre a história da imigração no país e de tabelas com dados censitários; a segunda parte apresenta reflexões mais subjetivas (mas não necessariamente um efeito um efeito de subjetividade), na medida em que explicita um ponto de vista mais pessoal por meio de adjetivações, de avaliações e de propostas para questões que, pela época em que o texto foi publicado, aparentemente já estariam solucionadas (como a assimilação dos imigrantes japoneses, por exemplo).

Veremos como as duas partes do texto de Reis se relacionam. Nossa hipótese é a de que a primeira parte do texto (dotada do efeito de sentido de objetividade) serve de base para uma concepção "cordial" da sociedade brasileira, um dos elementos de sua reflexão quando trata da imigração no Brasil. Por extensão, procuraremos mostrar como a História pode ser utilizada 
como um respaldo para a construção de uma imagem positiva da sociedade brasileira.

Mesmo sem apresentar traços explícitos de intolerância, como mostraremos na análise do artigo, o autor retoma conceitos como raça e assimilação (utilizadas em textos claramente intolerantes publicados no século XIX e nas primeiras décadas do século XX). É com base nesses conceitos, e na menção de certos autores considerados preconceituosos ${ }^{132}$, que o texto procura dar prosseguimento à sua discussão sobre a imigração no Brasil.

Examinaremos, rapidamente, a primeira parte do texto, cujo efeito de sentido mais objetivo revela um pensamento histórico-enuncivo por meio da convocação de elementos históricos e dados estatísticos para caracterizar a história da imigração no Brasil. Na segunda parte, veremos um pensamento mais sociológico-enunciativo, que aponta para alguns dos valores nos quais esse enunciador crê (sobretudo em relação à construção da imagem do país). Começaremos, então, pela análise da descrição da história da imigração no Brasil.

\section{A História escrita com objetividade}

O discurso de Reis apresenta uma diferença significativa em relação aos demais textos analisados neste capítulo. Trata-se da ênfase dada à história da imigração no Brasil. Evidentemente, a história da imigração aparece nos textos de Côrtes e Cardoso, mas muito esporadicamente. Veremos, nesta seção, alguns traços dessa particularidade do texto de Reis, assim como a função que ela tem no desenvolvimento de sua discussão a respeito da imigração no país.

A parte a que chamamos de discurso objetivo ou pensamento históricoenuncivo está presente nas seguintes seções do artigo de Reis: "III. As correntes imigratórias"; "IV. Migrações internas"; "V. A imigração em São Paulo" e na primeira parte da seção "VI. Os imigrantes japoneses". As características gerais dessas partes são as seguintes: debreagens enuncivas (actanciais, temporais e espaciais); progressividade histórica, ancoradas nos anos debreados enuncivamente; e uso de tabelas para apresentar o aumento

\footnotetext{
${ }^{132}$ Reis cita autores que tratam da imigração no Brasil, como Oliveira Vianna.
} 
populacional de imigrantes no Brasil, englobando os diversos grupos que para cá vieram.

Para cada um das seções mencionadas, iremos exemplificar com pequenos trechos as características acima descritas.

Resumidamente, a seção "III. As correntes imigratórias" descreve a história da imigração no Brasil desde o tempo da colonização portuguesa, passando pelos séculos XVIII (vinda de açorianos) e XIX (quando, de fato, inicia-se a imigração tal como a conhecemos, ou seja, com a entrada de indivíduos vindos de outros países e não apenas de Portugal e de suas colônias) (Reis, 1961: 74-79).

Em 1824, começaram a se fixar no Rio Grande do Sul os colonos alemães, onde surgiu (em 1827) a colônia de S. Leopoldo; depois apareceriam a de Torres, Nova Hamburgo e, em 1848, a colônia de Santa Cruz. Por volta de 1850, fundaram-se as colônias de D. Pedro II, Monte Bonito, Rincão del-Rei e Mundo Novo.

A partir de 1874 , os italianos instalaram-se no Rio Grande do Sul, formando as colônias de Conde d'Eu (Garibaldi), D. Isabel (Bento Gonçalves) e Caxias. Em 1885 e 1886 radicaram-se, os peninsulares, em Alfredo Chaves (Verannópolis e Antônio Prado) (Reis, 1961: 76)

Na seção "IV. Migrações internas", o texto apresenta um panorama geral do movimento interno de brasileiros com o advento do ciclo da mineração, passando pelo ciclo cafeeiro até chegar ao ciclo da borracha e à construção de Brasília (Reis, 1961: 79-80).

Tivemos, no passado, as migrações provocadas pelo ciclo de mineração (1690 a 1760), quando os bandeirantes paulistas e depois aludes nordestinos convergiram para as minas das Gerais, de Goiás e Mato Grosso. O ciclo cafeeiro do Vale do Paraíba (1810 a 1860) e do planalto paulista exerceram sua força centrípeta atraindo milhares de mineiros e nordestinos. $O$ ciclo áureo da borracha (1869-1908) arrastou para a Amazônia os sertanejos do Nordeste (Reis, 1961: 79).

Em "V. A imigração em São Paulo", o marco histórico inicial inscrito no texto é o século XIX (1878). Essa seção descreve o início da imigração para São Paulo e mostra que o início da imigração foi motivado pelo desenvolvimento agrícola do estado, sobretudo pela cultura cafeeira que necessita de trabalhadores agrícolas. 
Em 1887, fundou-se, em S. Paulo, sob a direção do Visconde de Parnaíba (D. Antônio Queiroz Teles) e do Conselheiro Antônio Prado, a Sociedade Paulista de Imigração e, nesse mesmo ano, foi inaugurada a Hospedaria dos Imigrantes, com capacidade para 1.200 pessoas, cuja construção fora autorizada pela lei no. 56, de 1885 do Governo Provincial de S. Paulo (Reis, 1961: 82).

Já a seção sobre a imigração japonesa em São Paulo, objeto de descrição de outra seção, começa pela menção da chegada do navio Kasato Maru em 1908 e se estende até a rápida descrição das principais cidades paulistas que contam com colônias de origem nipônica (Reis, 1961: 80-83).

Como se vê, pelos dados estatísticos acima, de 1958, a grande maioria $(77,7 \%)$ dos imigrantes japoneses está fixada em S. Paulo. Entretanto, a concentração desses imigrantes no Estado bandeirante fora mais acentuada em períodos anteriores. Artur Ramos no informa, apoiado em dados censitários oficiais, que, em 1940, $91,64 \%$ do total dos japoneses existentes no Brasil residiam em território paulista e, em 1950, as terras de Piratininga abrigavam $82 \%$ da totalidade dos imigrados amarelos já citados, seguindo, em segundo lugar, o Paraná com 15\%, Mato Grosso com $1 \%$ e o restante do país com $2 \%$ (Reis, 1961: 85).

Todos os trechos apresentam as características discursivas mencionadas acima. Vemos, assim, que essa parte do artigo é feita com debreagens enuncivas pessoais ("eles", os imigrantes), temporais (os anos instaurados no discurso) e espaciais (as cidades ou regiões para onde foram os imigrantes). Além disso, o efeito de sentido de objetividade presente nessas seções é reforçado pelo uso de tabelas com dados censitários:

\section{Os estrangeiros em São Paulo}

\begin{tabular}{|c|c|}
\hline total dos habitantes & Total dos estrangeiros \\
\hline $1872 \ldots \ldots \ldots \ldots \ldots \ldots \ldots . . . .237 .354$ & ............3,54 \\
\hline $1890 \ldots \ldots \ldots \ldots \ldots \ldots \ldots \ldots \ldots \ldots \ldots \ldots . .384 .753$ & $75.030 \ldots \ldots \ldots \ldots \ldots \ldots \ldots \ldots \ldots \ldots \ldots \ldots \ldots \ldots \ldots \ldots \ldots \ldots$ \\
\hline $1900 \ldots \ldots \ldots \ldots \ldots \ldots \ldots \ldots \ldots \ldots \ldots \ldots . .2 .282 .279$ & $476.778 \ldots \ldots \ldots \ldots \ldots \ldots$ \\
\hline $1920 \ldots \ldots \ldots \ldots \ldots \ldots \ldots . . . . .592 .188$ & 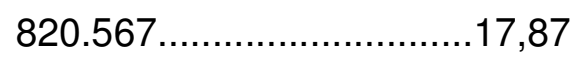 \\
\hline $1940 \ldots \ldots \ldots \ldots \ldots \ldots \ldots \ldots . .180 .316$ & 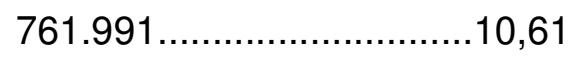 \\
\hline $1950 \ldots \ldots \ldots \ldots \ldots \ldots \ldots \ldots \ldots \ldots \ldots .134 .423$ & $627.433 \ldots \ldots \ldots \ldots \ldots \ldots$ \\
\hline
\end{tabular}

(Reis, 1961: 83) 
Uma característica que chama a atenção nessas seções é a da ausência completa de conflitos ou problemas gerados pela presença dos imigrantes. Todos os fatos históricos são apresentados (tal como o trecho acima) de forma objetiva e sem praticamente qualquer julgamento de valor. Dessa forma, a história é apresentada como uma ciência objetiva, ou melhor, como fatos objetivos que se narram praticamente sozinhos.

Essa ideia do discurso histórico pode ser encontrada, inicialmente, no famoso estudo de Benveniste a respeito do tempo verbal francês. Nesse trabalho, Benveniste faz a distinção entre narrativa histórica e discurso. A diferença básica reside, segundo Benveniste, nos limites de uso de determinadas formas verbais para a narração histórica (enquanto no discurso, todas as formas são possíveis) (Benveniste, 1976: 267-270). A distinção entre narrativa histórica e discurso pode ser assim resumida: "Os acontecimentos são apresentados como se produziram, à medida que aparecem no horizonte da história. Ninguém fala aqui; os acontecimentos parecem narrar-se a si mesmos" (Benveniste, 1976: 267). Dessa forma, a narrativa histórica é produzida, frequentemente, por meio de debreagens (actanciais, temporais e espaciais) enuncivas.

O único momento em que aparece uma avaliação do enunciador, quanto ao mérito da imigração no Brasil, ocorre ao tratar da imigração chinesa:

O Ministro de D. João VI, Conde de Linhares, fez realizar a exótica experiência do estabelecimento, na fazenda de Santa Cruz, de colonos chineses destinados às plantações de café (Reis, 1961: 76).

O uso do adjetivo "exótica" para se referir à tentativa de implantação da imigração chinesa no Brasil é o único momento em que o enunciador foge do efeito de objetividade dessas seções que tratam da história da imigração no Brasil. O "exótico" marca, assim, em seu discurso, uma diferença entre a imigração chinesa e a imigração feita com os europeus, do ponto de vista do enunciador. Se a imigração chinesa não é considerada explicitamente indesejável ou ruim para o enunciador, ela ao menos fica marcada por apresentar um traço "estranho" ao ponto de vista de Reis, qualificando-a, assim, negativamente, em comparação com a "normalidade" da imigração europeia para o Brasil. 
Veremos, abaixo, como essa forma objetiva de descrever a história da imigração no Brasil pode servir como base para a construção da imagem da sociedade brasileira. Já adiantamos que essa imagem é a de um país desprovido de conflitos ou de preconceitos por parte da sociedade que recebe os estrangeiros em seu espaço, tal como é descrita em sua História. E por receber bem, a concepção de assimilação dos estrangeiros, em particular do japonês, que prevalece no texto de Reis, é a de uma combinação de "vontade" do imigrante em ser assimilado e uma "receptividade franca" da sociedade brasileira.

Essa imagem de um país desprovido de preconceito ou de conflitos não necessariamente leva à ideia de que não existam problemas no processo imigratório brasileiro. Veremos a seguir como o discurso de Reis concebe os problemas imigratórios pelos quais 0 país estaria passando. Consequentemente, seu discurso apresenta também propostas para a solução desses mesmos problemas.

\section{O problema nacional e a solução por meio da imigração}

Como já vínhamos sublinhando desde o início deste capítulo, os discursos em torno do tema "imigração" apresentam, por vezes, críticas ao modo como o processo imigratório é conduzido em seu tempo. Uma das consequências dessas críticas está na apresentação de propostas de reforma do processo imigratório. $O$ texto de Reis se caracteriza por apresentar propostas sobre a melhor forma de conduzir a imigração no Brasil. Mesmo sendo um texto publicado já na década de 1960, o trabalho de Reis possui propostas para seleção e assimilação dos imigrantes, em uma direção muito parecida com a tomada por Côrtes, como já dissemos anteriormente.

Antes mesmo de apresentar suas propostas, Reis aponta para a falta de um maior número de imigrantes no espaço social e econômico brasileiro. Ao mesmo tempo, o texto mostra que essa falta não é acompanhada de um fazer do governo que vise à sua eliminação. Percebe-se que o texto de Pereira dos Reis descreve o mesmo problema apontado, em 1947, pelo texto de Geraldo de Menezes Côrtes. 
A semelhança entre os dois textos prossegue, pois, a despeito da existência dessa falta, o que há efetivamente, para o enunciador, é a dificuldade de aumentar o número de imigrantes no país por conta da política imigratória restritiva do governo brasileiro. Até a motivação para a política restritiva é a mesma nos dois textos: o medo da formação dos "quistos étnicos", como podemos ver no trecho abaixo:

\begin{abstract}
O Brasil, com suas vastas extensões territoriais despovoadas, com sua baixa densidade demográfica (6,1 hab. por km. quadrado em 1950, e 7,72 habitantes por km. quadrado em 1960) é um país que necessita de imigrantes que auxiliem, com o seu trabalho, a dinamização das riquezas nacionais.

Apesar disso, no país, houve e há uma série de medidas restritivas que procuram acautelar os interesses brasileiros, temendo-se a formação de 'quistos' raciais e culturais de difícil assimilação aos costumes, hábitos e à língua nacionais (Reis, 1961: 72).
\end{abstract}

No trecho acima, temos quatro questões pertinentes: a) o problema da falta de pessoas em determinadas regiões do país; b) a política imigratória restritiva; c) o isolamento dos imigrantes nos chamados "quistos étnicos"; d) o desenvolvimento econômico nacional.

Além da política restritiva, o discurso de Reis aponta ainda outro fator, agora histórico, para a falta de imigrantes no país. Essa falta decorre, segundo o enunciador, do fato de o Brasil, por um longo tempo, ter afugentado bons imigrantes, que optaram pela entrada nos EUA ou na Argentina. Três são os fatos citados para explicar essa situação: a escravidão, o clima e a epidemia de febre amarela. Esses elementos seriam, assim, responsáveis pelo afastamento de bons imigrantes que poderiam contribuir para o desenvolvimento do país:

Os imigrantes europeus preferiram a Argentina e os Estados Unidos porque, no Brasil, três fatores eram desfavoráveis à imigração: a existência da escravidão (repelindo o trabalho livre), o clima (com suas endemias tropicais e a epidemia de febre amarela) (Reis, 1961: 74).

Consequentemente, a presença desses fatores se tornou parcialmente responsável pelo pequeno número (do ponto de vista do enunciador) de imigrantes que entraram no Brasil, sobretudo quando comparado com os fluxos migratórios em direção à Argentina e aos Estados Unidos. O apontamento desse problema histórico é uma diferença significativa em relação ao texto de Côrtes, pois o discurso de Reis se debruça muito mais nos acontecimentos 
históricos para mostrar os problemas da imigração no Brasil e para encarar a situação da imigração de seu tempo.

Mesmo com essa percepção do problema da falta de imigrantes no país, seja pela restritiva política imigratória seja porque o Brasil não foi por um bom tempo um país atraente para os imigrantes, o enunciador crê na possibilidade de aumentar o número de imigrantes no país. Para isso, é preciso, segundo ele, eliminar o medo da criação dos 'quistos étnicos' em solo nacional.

O "quisto étnico", como um antiobjeto, se configura pela restrita circulação de objetos distintos do que já é conhecido pela comunidade estrangeira, gerando, assim, dificuldades para o imigrante adquirir os costumes, os hábitos e a língua nacional do Brasil. A concentração de traços culturais estrangeiros (e estranhos à totalidade da cultura brasileira) em um espaço relativamente pequeno e fechado dificulta a adoção de outro padrão. Por isso, o chamado "quisto étnico", constituído pelo fechamento completo da comunidade imigrante, impede um maior contato com a sociedade brasileira. Esse fechamento implica duas questões: permitir a manutenção dos valores e hábitos trazidos pelos imigrantes e, ao mesmo tempo, impedir a transformação dos valores e hábitos comuns à comunidade imigrante, como já dissemos nas outras duas análises deste capítulo.

Como nos demais textos analisados, o discurso de Reis apresenta a seguinte organização ${ }^{133}$ para o problema imigratório no Brasil:

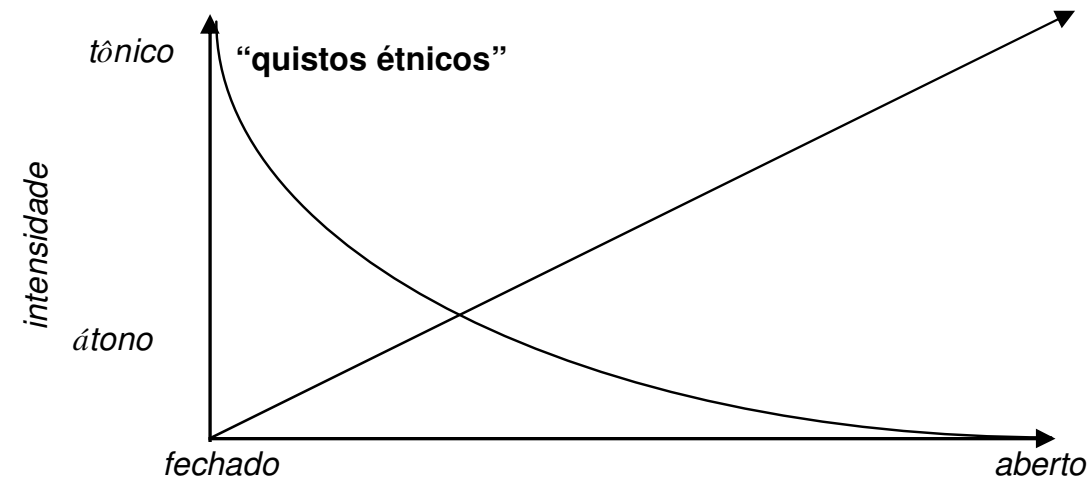

extensidade

\footnotetext{
${ }^{133} \mathrm{Na}$ parte final desta análise, retomaremos o esquema para completá-lo.
} 
Como vimos no trecho acima, há um medo, mencionado por Reis, relacionado à formação dos "quistos étnicos" no país. A paixão do medo, como mostra Fiorin, possui duas formas igualmente regidas pela modalidade do /saber/. A primeira se organiza como a expectativa de uma sanção negativa pelo destinador-julgador. O medo aparece no segundo caso em uma relação entre um sujeito de estado e um antissujeito cuja ação pode ser considerada uma ameaça, pois o antissujeito pode privar o sujeito de estado de seu objeto-valor (Fiorin, 1992: 57). É justamente esse o caso que vemos no discurso Reis. O medo da formação dos "quistos étnicos" decorre do conhecimento do Estado brasileiro sobre a possibilidade de o imigrante isolado ameaçar a unidade nacional. Há, assim, um medo de eles não contribuírem para o desenvolvimento econômico e um medo de ameaçar a unidade nacional.

Como vemos no primeiro trecho citado nesta seção, o imigrante é o sujeito que vem para trabalhar no país e, mais do que isso, auxiliar no aceleramento do desenvolvimento econômico nacional. Dessa forma, o imigrante é o adjuvante necessário para o país aumentar consideravelmente sua economia, que não está, segundo o enunciador, se desenvolvendo de modo adequado. Essa é a mesma ideia que permeia o discurso de Côrtes, como vimos na primeira análise deste capítulo.

Dessa maneira, há duas linhas de pensamento complementares no discurso de Reis. De um lado, a falta de um maior número de imigrantes no país, cuja solução não é realizada por causa de uma política restritiva ao estabelecimento de estrangeiros, motivada pelo medo do surgimento dos "quistos étnicos". De outro, as suas considerações sobre assimilação do imigrante pela sociedade brasileira, que diminuiria o receio dos "quistos étnicos" e aumentaria a presença de estrangeiros em solo brasileiro. Esse é o mesmo tipo de raciocínio encontrado no discurso de Geraldo de Menezes Côrtes quando apresentou suas propostas para uma política imigratória no Brasil 14 anos antes do discurso de Pereira dos Reis.

\section{A seleção dos imigrantes: uma forma simples de triagem}


Como dissemos acima, a proposta de seleção visa, em última instância, a permitir a entrada somente do imigrante considerado bom para o país. Nesse movimento de seleção, constrói-se a imagem do imigrante ideal para o Brasil.

Mesmo que de forma não tão elaborada como no texto de Côrtes, Pereira Reis também apresenta sua proposta de seleção. $O$ trecho abaixo mostra como o operador triagem está presente no discurso de Reis. Trata-se, nesse caso, de uma triagem átona, uma vez que não há uma exclusão explícita a um determinado grupo imigrante. Assim, de modo mais generalizado, o texto de Reis apresenta alguns traços do que pode ser considerado o imigrante ideal:

O ádvena ideal não deve ser escolhido apenas pelo seu poder de adaptação biológica ao novo clima, ao novo regime alimentar, ao novo tipo de vestuário ou de mera acomodação sociológica às novas condições econômicas e culturais do grupo social em que vai viver, mas, também, pela capacidade de assimilação de seus descendentes pela comunidade nacional (Reis, 1961: 72).

A seleção para Reis deve considerar a competência (/poder-fazer/ e /poder-ser/) do imigrante em se adaptar a todas as condições apresentadas em solo brasileiro. Em outras palavras, é importante, para o enunciador, pensar na competência do imigrante em se ajustar ao novo ambiente, seja esse ajustamento uma adaptação racial/biológica, social, econômica ou cultural. O texto de Reis considera ainda a capacidade de assimilação dos filhos dos imigrantes fundamental para o ingresso no país, questão que será retomada na próxima seção.

Em comparação ao texto de Côrtes, a organização modal do bom imigrante é mais simples. Isso ocorre porque em Côrtes o imigrante deve ter, como vimos, diferentes modalidades que determinam seu papel temático: /querer-ser/ e /poder-fazer/ (no caso do proprietário de terras); e /saber-fazer/ (no caso do trabalhador industrial).

Reis afirma ser necessária atenção à raça e à formação religiosa, moral, política e também aos hábitos e costumes dos imigrantes que entram no país, enquanto critérios a serem aplicados para sua seleção.

Como disse Castro Barreto, o 'homem é, sem dúvida alguma, o valor fundamental das civilizações, porque é a unidade dinâmica de todo o progresso'; assim sendo, o Brasil, como país de rala densidade demográfica, 
necessita de imigrantes (que devem, de preferência, ser selecionados por raça, formação religiosa e moral, educação política, hábitos e costumes) para acelerar o seu desenvolvimento (Reis, 1961: 73).

Veremos, na parte relativa à assimilação, que esses critérios de seleção acima descritos ("raça, formação religiosa e moral, educação política, hábitos e costumes") estabelecem uma hierarquia de preferência dos grupos imigrantes para o país.

Além do aspecto econômico, Reis mostra ainda outros benefícios para a sociedade brasileira advindos da presença dos imigrantes, como podemos ver no trecho abaixo:

O imigrante representa um valor positivo (quando selecionado) para o país que o abriga porque, além de constituir um capital-homem que foi preparado e assistido econômica, educacional e sanitariamente pela pátria donde emigrou, contribui para o desenvolvimento da produção, para o enriquecimento da cultura, das experiências e de novas técnicas agrárias, comerciais ou industriais (Reis, 1961: 73).

O enunciador revela assim qual o papel do imigrante ideal para o país. $O$ imigrante bem formado em seu país de origem e o que possui traços étnicos/raciais e culturais (religião, boa moral, educação política, hábitos e costumes apropriados) próximos ao que é desejado para a nação brasileira. Além disso, o imigrante só é considerado "positivo" para o enunciador se for selecionado. Mesmo sem, como dissemos, o detalhamento de Menezes Côrtes, o discurso de Reis apresenta igualmente uma visão de raça da seleção imigratória para o Brasil.

Veremos, a seguir, algumas diferenças e semelhanças em relação à concepção de assimilação encontrada no discurso de Reis para fazer um contraponto com as considerações de Côrtes e Cardoso, que também tratou do tema da assimilação.

\section{Entre o ajustamento e a completa assimilação: percursos de transformação do imigrante e da sociedade brasileira}

Dentre as propostas para uma política imigratória que vise à eliminação do problema (ou da ameaça) do "quisto étnico" no país, Reis apresenta, tal como Côrtes, estratégias para a assimilação do imigrante. Além das similitudes 
entre os dois discursos, veremos, principalmente, quais as diferenças entre eles no que tange à concepção de assimilação.

Inicialmente, o texto de Reis explicita quais os valores que devem ser preservados no processo imigratório: a unidade política da nação brasileira. $O$ enunciador mostra seu desejo por uma assimilação do estrangeiro realizada o mais rápido possível, principalmente para que a unidade nacional não seja ameaçada:

É preciso ter como principal escopo a defesa da unidade política da Pátria, orientando o Estado a absorção dos elementos adventícios, que se deve processar em etapas mais curtas possíveis (Reis, 1961: 87).

O texto de Reis apresenta a assimilação como uma solução para enfrentar o receio da formação de "quistos étnicos" no país. Essa é a forma de se ver livre dessa "ameaça" e ainda contaria com a presença de trabalhadores imigrantes que contribuem para o desenvolvimento econômico do país, não diferindo muito das propostas de Côrtes. Outra semelhança com o texto de Côrtes está no fato de atribuir ao Estado brasileiro a incumbência de realizar a assimilação dos imigrantes.

Contudo, há também uma primeira diferença significativa a respeito da assimilação dos imigrantes. Reis considera que todo imigrante é assimilável, sobretudo quando o imigrante apresenta a vontade de se integrar, como veremos abaixo. Além disso, outras características são necessárias para que o imigrante se integre à sociedade brasileira, como a proximidade dos padrões culturais brasileiros e estrangeiros:

\footnotetext{
Nem sempre o imigrado está condenado a condições de 'homem marginal'. Tudo dependerá da existência ou não de conflito e da disposição, aliás pouco provável em se tratando de indivíduos de padrões culturais muito diferentes, do alienígena abandonar as tradições, ideias, conceitos, hábitos e a língua da terra de origem substituindo-os pelos da pátria que adotou.

Essa assimilação só é exequível quando o imigrante possuir afinidades étnicas e culturais com o novo agrupamento social em que vai viver, que condicionarão a sua plena integração sentimental e moral (Reis, 1961: 72).
}

Para que a assimilação do imigrante seja um sucesso ("plena integração sentimental e moral"), dois aspectos são ressaltados no trecho acima. $O$ primeiro se refere à vontade ("disposição) do imigrante como forma fundamental de sua integração à sociedade brasileira. Esse é um dos traços 
que diferencia o texto de Reis do de Côrtes, que não constrói a figura do imigrante com o valor modal do /querer-ser/, mas com o do /querer-fazer/. O segundo trata da afinidade étnica e cultural do imigrante em relação à sociedade brasileira, o que evitaria o conflito entre culturas (a brasileira e a dos diferentes imigrantes). Em outras palavras, a vontade do imigrante em se integrar à sociedade brasileira é fundamental, sem a qual não há sucesso na assimilação (ou seja, o imigrante pode até ter os traços culturais e étnicos próximos ou idênticos aos da sociedade brasileira, mas se ele não quer, não é possível a realização da integração). Podemos, assim, resumir as condições para uma assimilação bem sucedida na "equação" abaixo:

\section{Vontade de se integrar + Afinidade étnica e cultural = sucesso da integração.}

A questão da afinidade étnica e cultural é um indício dos valores articulados no discurso de Reis. Mais abaixo, completaremos esse quadro de valores e identificaremos o espaço ocupado pelos imigrantes japoneses em relação à sociedade e à cultura brasileiras. Podemos dizer que a busca pela aculturação do nissei é, em parte, uma tentativa de diminuir essa distância entre dois universos (social e cultural) distintos, como vimos em Cardoso.

No texto de Reis, o imigrante que tem maior possibilidade de se integrar à sociedade brasileira é justamente aquele que já tem, de antemão, as características mais próximas dos traços definidores da nação brasileira ("afinidades étnicas e culturais"). $O$ discurso de Reis pressupõe a existência de um universo étnico e cultural mais ou menos homogêneo que serve como parâmetro para se afirmar qual ou quais são os grupos imigrantes que mais se aproximam desse ideal.

Mesmo com a lógica da afinidade de traços culturais e étnicos, o texto coloca a assimilação, do ponto de vista do imigrante, como um desafio a ser superado. Esse desafio é tematizado pelas diferenças geográficas, sociais, culturais e sanitárias. E por se tratar de um desafio, está também prevista a possibilidade de insucesso do imigrante:

O imigrante, ao se fixar em outro país, terá, forçosamente, que enfrentar o problema do ajustamento às novas condições geográficas, sociais, culturais e 
sanitárias, sofrendo não somente os riscos dos fracassos sociais, como das enfermidades e mesmo da morte (Reis, 1961: 72).

Nessa obrigatoriedade de se ajustar, diferentes graus de dificuldades surgem diante do estrangeiro: as dificuldades advindas da região em que ele vai se estabelecer (dificuldades climáticas e espaciais), os problemas sociais (condições materiais de vida, relação com brasileiros e outros grupos imigrantes, falta de infraestrutura na colônia, etc.) e as diferenças culturais (hábitos, língua, alimentação, etc.). Todos esses "obstáculos" podem ser superados com alguma facilidade ou não, conforme a vontade do imigrante e a sua afinidade étnica e cultural. É também por meio da vontade (/querer-fazer/ e /querer-ser/) que o imigrante pode ser classificado, no discurso de Reis, como bem sucedido ou fracassado. Em outras palavras, ter mais vontade significa ter mais chances de o imigrante se adaptar ao país e, assim, ser bem sucedido. Quando há uma menor vontade, consequentemente o resultado é uma menor possibilidade de adaptação e, assim, uma maior chance de fracasso do imigrante (figurativizado como "homem marginal").

Ajustar-se, no caso do presente texto, significa adaptar-se às novas condições materiais e simbólicas do contexto brasileiro. Veremos na seção dedicada à imigração japonesa como esse "ajustar-se" é uma forma de assimilação parcial do imigrante em território brasileiro, ou seja, uma etapa dentro de um processo mais longo que vai culminar na assimilação, sobretudo, dos descendentes dos imigrantes. De qualquer maneira, o texto pressupõe que o ajustamento é uma operação da qual o imigrante não tem como escapar ("forçosamente").

Como vimos no texto de Côrtes, a relação entre imigrantes e parcela da sociedade brasileira ocorre em termos de mistura. De um lado, imigrantes dotados de nível cultural "superior" e, de outro, parcela da sociedade brasileira caracterizada por um nível cultural "inferior". Apesar das operações distintas, veremos como o propósito de se colocar imigrantes e brasileiros em interação é o mesmo nos dois autores (elevar o nível cultural e étnico/racial da sociedade brasileira).

Além dos elementos acima mencionados, todos da esfera da cultura, o texto retoma, no debate sobre a assimilação, a questão biológica da adaptação e da integração do imigrante ao ambiente brasileiro: 
A adaptação biológica do adventício ao 'habitat' em que se veio fixar, aos novos padrões dietéticos e, paralelamente, o seu ajustamento psicosociológico realizam-se, paulatinamente, em maior ou menor intensidade, conforme o grau de organização da sociedade em que vão viver (Reis, 1961: 86).

Ainda no trecho acima, que se refere à "adaptação biológica", é possível observar que a integração é um processo gradual na perspectiva de Reis. Além disso, o tema "biológico" ou "racial" serve como um valor para o enunciador estabelecer uma hierarquia dos grupos imigrantes. Parte-se, assim, dos grupos considerados mais facilmente assimiláveis (do ponto de vista cultural e racial) para os que apresentam alguma dificuldade de integração:

Além do fenômeno sociológico de assimilação há o fenômeno biológico da fusão racial. Sob o aspecto étnico, os portugueses, espanhóis e italianos e menos os semitas (sírios e libaneses) demonstraram expressivos índices de fusibilidade, contribuindo expressivamente para o 'melting-pot' brasileiro (Reis, 1961: 73).

No trecho acima, vemos que o tema étnico/racial rege a hierarquização dos melhores imigrantes a serem assimilados. Isso ocorre por causa da afinidade étnica mencionada anteriormente. Dessa forma, um primeiro grupo é considerado mais facilmente assimilável (portugueses, espanhóis e italianos), seguido por árabes (sírios e libaneses). Relacionando a hierarquização dos grupos de imigrantes com os critérios de seleção, podemos observar que o imigrante ideal construído no texto de Reis se aproxima da figura do imigrante presente no discurso de Côrtes: trabalhador, branco, cristão e "civilizado".

O percurso da integração/assimilação previsto no discurso de Reis apresenta dois desdobramentos temáticos no nível discursivo. O primeiro se refere à assimilação como um processo social. O segundo processo é o da fusão racial, enquanto uma integração biológica do estrangeiro ao corpo social nacional. Em ambos os casos, há uma etapa prévia de adaptação (sociocultural e biológica) antes da integração completa.

O texto apresenta, assim, todo um conjunto de reflexões a respeito da adaptação e da assimilação do imigrante. Nesse sentido, há duas formas de interação presentes no texto: a primeira, do imigrante recém-chegado, que, mais do que se integrar, precisa se adaptar, ou seja, se ajustar ao novo 
ambiente. A segunda forma de interação, a assimilação propriamente dita, se refere principalmente à geração seguinte, quando existe o abandono do quadro cultural de origem dos pais para ocorrer a inserção completa na cultura no novo país:

Não se pode negar que as migrações acarretam novos contatos e conflitos culturais e o imigrante que é obrigado a adotar a língua, os hábitos e conceitos morais e religiosos diferentes, facilmente é jogado -, quando não se consegue ajustar, satisfatoriamente, às condições bio-sociológicas do país onde se veio fixar - na marginalidade, fato que não impede que seus descendentes imaturos se integrem, às vezes, sem resistências, dentro dos padrões culturais da pátria que adotaram ou onde nasceram. Os filhos dos adventícios, quando abandonam os sinais culturais que caracterizam o alienígena são indivíduos assimilados (Reis, 1961: 72).

Pelo trecho acima e anteriores, vemos a construção de duas imagens do imigrante: a do imigrante bem sucedido, que é aquele que consegue se ajustar à sociedade brasileira, mesmo sem uma integração completa; e a do imigrante fracassado, que não consegue se adaptar à sociedade brasileira. Em certa medida, o imigrante bem sucedido está próximo do sujeito regido pelo ajustamento, tal como postulado por Landowski, por se adaptar bem a um ambiente (social, cultural e biológico) que não é o seu de origem e, a partir daí, tirar o melhor proveito dessa experiência sensível e nova. Enquanto isso, o imigrante fracassado é representado pela alteridade caracterizada pela segregação ou mesmo pela sua completa exclusão por não conseguir, justamente, se inserir em um ambiento distinto do seu.

Como já visto no discurso de Côrtes, Reis apresenta, sem o mesmo detalhamento, uma proposta de distribuição dos imigrantes como uma forma de aumentar as chances de assimilação. De um lado, imigrantes de determinada nacionalidade não podem ser a maioria em uma cidade ou colônia para não surgir um novo "quisto étnico". De outro lado, os brasileiros devem estar presentes em maior quantidade para facilitar e aumentar as chances de assimilação do imigrante, como vemos no trecho abaixo:

A política ideal que se deve adotar com os imigrantes é distribuí-los em sociedade em que sejam minoritários e não permaneçam segregados, de modo que se processem os fatos aculturativos e sejam, gradativamente, assimilados pelos grupos nacionais (Reis, 1961: 87). 
Evitar a segregação por meio do contato com brasileiros é uma forma de se evitar a formação dos chamados "quistos étnicos". Mas esse contato, no discurso de Reis, não é compreendido como uma assimilação integral e imediata. O contato se insere, ainda, no regime de ajustamento, sempre do lado do imigrante. $O$ autor não perde de vista a necessidade de integração do imigrante, mas reconhece que essa integração é feita de modo lento e contínuo ${ }^{134}$ :

Não se pode pretender que o imigrado sofra, ao descer em solo brasileiro, uma modificação profunda na sua personalidade com a desintegração, quase repentina, de toda a sua cultura de origem e aceitação, com facilidade e sem resistência, da língua, dos ideais, conceitos, hábitos, costumes, do vestuário e da alimentação da pátria adotiva. Tal destruição violenta provocaria a despersonalização do ádvena, o desequilíbrio psíquico e, consequentemente, neuroses graves (Reis, 1961: 86).

Dentre os elementos nacionais com os quais o imigrante mantém contato ao entrar no país estão presentes, no discurso de Reis, temas abstratos (como ideais e conceitos), figuras como vestuário e alimentação (tema cultural) até práticas (como a língua e os hábitos). Em outras palavras, o texto mostra que o processo de assimilação, tal como almejado pelo país (e por autores do passado, como vimos), é uma interação complexa, que envolve diferentes elementos e etapas até se obter a integração completa de todos os elementos definidores da identidade nacional por parte do imigrante. A diferença de Reis para outros autores, vistos neste capítulo, está na velocidade em que ocorre essa assimilação, que passa por uma fase de ajustamento para chegar depois à assimilação completa com os filhos dos imigrantes. $O$ enunciador reconhece que, sem a aceitação dessa progressão, e sobretudo a velocidade em que ela ocorre, o imigrante não consegue se integrar com sucesso ao país.

Vínhamos mostrando que o ajustamento ao qual o imigrante deve submeter-se é uma adaptação feita somente do lado dele. No entanto, o texto de Reis prevê ainda que o processo de interação entre imigrante e nacionais provoque uma modificação da unidade nacional (seja ela social, econômica, cultural ou étnica), não especificando se isso ocorre logo com os primeiros

\footnotetext{
${ }^{134}$ Mesmo falando da imigração em geral, os dois trechos seguintes estão presentes na seção sobre "A contribuição étnica e cultural do japonês" que será analisada a seguir (Reis, 1961: 85-88).
} 
imigrantes ou com os seus descendentes. De qualquer maneira, essa é uma considerável diferença em relação aos demais textos analisados neste capítulo:

\begin{abstract}
No entanto, a assimilação sendo um processo bilateral, apesar de prevalecerem os padrões de um grupo, 'acarreta a transmissão de artefatos, idéias e técnicas de indivíduo para indivíduo, de grupo para grupo, de cultura para cultura', tornando-se, nesse caso, a imigração 'fator condicionante ao início e ao desenvolvimento de novas formas sociais e culturais (Reis, 1961: 72-73).
\end{abstract}

No texto de Côrtes, há a ideia explícita de melhoria da sociedade brasileira pelo contato com o imigrante, melhoria que é apontada sem grandes detalhes por Reis, que menciona a ideia de mudança e de transformação de parcela da sociedade brasileira. O texto de Reis defende a ideia de que a presença dos imigrantes em solo nacional pode modificar os padrões sociais e culturais brasileiros ("processo bilateral"), mesmo reconhecendo o predomínio, sobretudo quantitativo, dos valores nacionais sobre os valores estrangeiros.

O ajustamento, mesmo tendo reflexo nos dois lados, nos leva a pensar que é realizado com velocidades distintas: na sociedade brasileira, as mudanças advindas da presença dos imigrantes é mais lenta, enquanto o ajustamento e a transformação por parte dos imigrantes, que precisam se adaptar à sociedade brasileira, devem ser mais rápidos (conforme o desejo de Reis), até como condição de sucesso e de sobrevivência do imigrante que se estabelece no Brasil.

Podemos ainda entender que uma velocidade maior de adaptação e de integração está proporcionalmente ligada a uma maior afinidade do imigrante com a sociedade brasileira, afinidade que pode ser medida pela hierarquia estabelecida por Reis. De qualquer forma, ele considera qualquer imigrante assimilável. Além disso, como já foi mencionado, deve haver ainda a vontade de o imigrante adotar os valores da sociedade que o recebe para, assim, se integrar. A diferença de Reis para os demais textos analisados está na concepção de sociedade brasileira construída em seu texto. Por isso, a sociedade brasileira deve também ser receptiva ao imigrante e nunca permitir a intolerância ou o preconceito:

O desenvolvimento do fenômeno de assimilação depende da disposição favorável dos dois grupos em contato: do imigrado desejando se radicar e se 
ajustar ao novo meio físico e sociológico e da conduta do grupo dominante que deve evitar o insultamento cultural dos adventícios, facilitando assim a aculturação (Reis, 1961: 87).

Como veremos no trecho abaixo, é por meio da miscigenação que Reis pensa na melhoria da sociedade brasileira. Nesse ponto, o discurso de Reis é muito próximo ao de Côrtes. Mas a semelhança com Côrtes se limita à ideia de melhoria da sociedade brasileira: ao contrário do texto publicado em 1947, o texto de Reis não apresenta explicitamente a ideia de que os imigrantes que chegam ao país são superiores à parcela mais pobre da sociedade brasileira que teria contato com os imigrantes. Sua perspectiva é, nesse sentido, mais ampla, por não dividir em classes a sociedade brasileira, que pode assim se beneficiar da presença de imigrantes como um todo. Nesse caso, a própria mistura é considerada um valor positivo para a sociedade brasileira:

É claro que, em se tratando de miscigenação em que entram em jogo a atitude de ambas as partes, seu aumento sensível implica a modificação, no sentido favorável, do comportamento do grupo dominante (Saito, apud Reis, 1961: 88).

De todo modo, o discurso de Reis prevê também a modificação da sociedade brasileira. Reis cita também Oliveira Viana que, como já dissemos, ficou para a história como um sociólogo de base racista em seus estudos sobre a formação da sociedade brasileira. Apesar de uma certa intolerância por citar Oliveira Viana, a continuação do texto mostra que ele constrói uma imagem positiva dos imigrantes japoneses. De qualquer forma, Reis cita, a partir de uma proposta de Oliveira Viana, as características necessárias para uma mestiçagem bem sucedida:

Como escreveu Oliveira Viana, o 'melting-pot' 'depende do maior ou menor número de imigrantes casados ou solteiros, masculinos ou femininos, da 'beleza plástica das raças componentes e do 'status' social do imigrante' (Reis, 1961: 88).

Mesmo com a descrição de todas as características do imigrante que melhor pode se adaptar e se integrar à sociedade brasileira, Reis não apresenta, em suas propostas, nenhuma forma de manipulação (por tentação e por sedução) para fixar o imigrante no país, como faz Côrtes em seu texto. Provavelmente, essa ausência de manipulação para que 0 imigrante se 
estabeleça no país se deva à ideia de dar prioridade ao que mostra maior vontade de integração e uma afinidade cultural e étnica/racial com a sociedade brasileira.

Mesmo estabelecendo os critérios como a vontade do próprio imigrante e a afinidade cultural e étnica como elementos fundamentais para uma assimilação bem sucedida, além de construir uma hierarquia dos melhores imigrantes (porque são mais facilmente assimilados) baseado implicitamente no critério racial, Reis acredita que os imigrantes japoneses, uma realidade no país, também podem ser assimilados, a despeito de suas diferenças em relação à sociedade brasileira. Veremos, assim, como o discurso de Reis constrói a imagem desse grupo imigrante e suas possibilidades de assimilação.

\section{Os imigrantes japoneses e a sociedade brasileira: formas de interação para se realizar a assimilação}

Depois de apresentar a história da imigração no Brasil e de propor a solução para os problemas relacionados ao processo imigratório, Reis se detém em um grupo específico. Trata-se de uma seção dedicada à imigração japonesa, na qual o enunciador procura desenvolver a questão do ajustamento e da assimilação desse grupo ${ }^{135}$.

O texto começa se referindo ao preconceito histórico contra o grupo nipônico no Brasil. O texto recupera, assim, a imagem do imigrante japonês como aquele que não pode ou não quer ser assimilado à sociedade brasileira:

Sofreu a imigração desse povo asiático uma série de críticas, por se considerar o nipônico inassimilável, constituindo um 'quisto' irredutível dentro da organização nacional. Vivaldo Coaraci, em trabalho de gabinete, defende a tese da inassimilibilidade do japonês; Miguel Couto e Artur Neiva preocuparamse com o então chamado 'perigo amarelo' apresentando, no Parlamento Nacional, projetos que recomendavam a imigração ariana e proibiam a japonesa (Reis, 1961: 85-86).

O enunciador se posiciona claramente contra essa visão preconceituosa que dominou parte dos debates sobre a imigração japonesa mesmo antes

\footnotetext{
${ }^{135}$ Como dissemos no começo da análise, há uma parte referente à história da imigração japonesa que, como as demais seções dedicadas à história da imigração no Brasil, apresenta um efeito de sentido de objetividade. A parte que analisaremos nessa seção é outra, intitulada "A contribuição étnica e cultural do japonês". Essa seção apresenta considerações mais subjetivas sobre esse grupo imigrante no Brasil.
} 
dessa imigração começar no Brasil. Enquanto se observa o preconceito de Coaraci, Couto e Neiva (citados no trecho acima) sobre a impossibilidade de assimilação do imigrante japonês, Reis defende uma outra imagem da imigração japonesa:

Hoje, a questão é encarada doutro modo e os problemas que se julgavam específicos da imigração japonesa (a conservação dos 'mores' de origem e da 'marca racial' pelos casamentos endogâmicos), nada mais são que problemas comuns, em maior ou menor escala, a todos os grupos de imigrante (Reis, 1961: 86).

A manutenção das tradições do país de origem e a dificuldade de assimilação (representada pelo casamento no mesmo grupo) ainda continuam sendo consideradas um problema para o enunciador. A diferença é que esse problema não é atrelado, no discurso de Reis, a um grupo imigrante específico, mas a todo e qualquer grupo imigrante. Dessa forma, o imigrante japonês já não é o único a possuir o papel temático do excluído (como nos discursos analisados anteriormente), ou seja, do que não quer ou não pode ser assimilado.

Um exemplo disso aparece na menção ao casamento endogâmico, ou seja, entre membros de uma mesma comunidade. A dificuldade em se aceitar 0 casamento com brasileiros ou com indivíduos de outras comunidades estrangeiras (casamento exogâmico) é um índice de que existe a manutenção das tradições do país de origem do imigrante, tal como apontado no estudo de Cardoso.

Essa diferença entre esses dois textos pode ser explicada por meio de uma outra forma de encarar a imigração japonesa no Brasil. Reis acredita que a assimilação não depende apenas do próprio imigrante, mas igualmente da parte da sociedade com a qual esses imigrantes entram em contato:

A verdade é que os japoneses serão absorvidos pelos grupos nacionais, dependendo os graus de homogeneidade e fusibilidade do tempo e da organização social em que estão em contato (Reis, 1961: 87).

Como vemos abaixo, o enunciador recorre a outros discursos para comprovar seu ponto de vista sobre a possibilidade de assimilação do 
imigrante japonês. No caso, o outro discurso citado é de dois autores de origem japonesa (Seiichi Izumi e Hiroshi Saito):

Estudos científicos realizados, principalmente por Seiichi Izumi e H. Saito, demonstram que o japonês é assimilável como qualquer outro imigrante. Ainda mais que, no sul do país, não existe, nos grupos sociais brasileiros uma atitude de hostilidade, de antipatia, prevenção ou de reserva contra os estrangeiros que obrigue os alienígenas, como ocorre frequentemente nos Estados Unidos, a ficarem segregados com diminutos contatos com a sociedade de nacionais, constituindo grupos minoritários que, repelidos, tendem a se organizar, étnica e culturalmente, conservando os seus padrões culturais e, pelo 'inbreending', a etnia originária $^{136}$. (Reis, 1961: 86).

O trecho acima mostra que uma postura intolerante ou preconceituosa por parte da sociedade que recebe os imigrantes pode contribuir para 0 distanciamento, o isolamento e a construção do "quisto étnico". Consequentemente, a integração do imigrante fica seriamente comprometida, uma vez que o contato entre a comunidade imigrante e a sociedade que 0 recebe torna-se mais difícil pelo isolamento de ambas as partes.

Dessa forma, a sociedade brasileira passa a ter um papel fundamental na assimilação do imigrante ao ser construída como mais tolerante e pacífica, como veremos abaixo. Podemos associar essa imagem àquela produzida nas seções que contam a história da imigração no Brasil, pois, como dissemos, não há qualquer menção de conflitos entre imigrante e sociedade brasileira.

O texto reafirma ainda essa imagem tolerante da sociedade brasileira por meio de uma nova citação H. Saito. Dessa forma, Reis utiliza o discurso do sociólogo de origem japonesa (e professor da Escola de Sociologia e Política de São Paulo) para mostrar que a imagem tolerante da sociedade brasileira não é apenas um ponto de vista seu:

\begin{abstract}
Alias, o ilustre professor da Escola de Sociologia e Política de S. Paulo reconhece que 'a rapidez da marcha aculturativa dos japoneses e seus descendentes em nosso meio, isso se deve, sobretudo à ausência - na cultura luso-brasileira - de padrões discriminatórios e de preconceitos efetivamente operantes que redundem em estímulo à formação e consequente persistência de grupos minoritários' (Reis, 1961: 86).
\end{abstract}

A sociedade brasileira, segundo o texto, não apresenta qualquer forma de preconceito contra o imigrante ("ausência - na cultura luso-brasileira - de

\footnotetext{
136 "Inbreending" é, literalmente, a geração de filhos por parte de um grupo social. Pode ser traduzido como "gestação".
} 
padrões discriminatórios e de preconceitos"). Por isso, a tendência que se configura no discurso de Reis é a de que a assimilação do imigrante japonês (e de todos os outros) depende igualmente da sociedade brasileira.

Ao contrário do discurso de Cortês, em que a abertura deve ocorrer na colônia imigrante para que ocorra a assimilação, o texto de Reis mostra que a abertura deve existir também na sociedade brasileira. No texto de Côrtes, a sociedade brasileira é formada por meio da noção de unidade que, no caso, entra em confronto com outra unidade constitutiva representada pela "quisto étnico". Por isso, existe a ideia predominante de assimilação em Côrtes, enquanto no discurso de Reis há uma etapa intermediária de ajustamento mútuo do imigrante e da sociedade brasileira, antes da integração. Dessa forma, retomando o esquema tensivo proposto acima, quando foi tratado o tema do "quisto étnico", podemos representar a relação entre o "quisto étnico" e a sociedade brasileira construída no discurso de Reis:

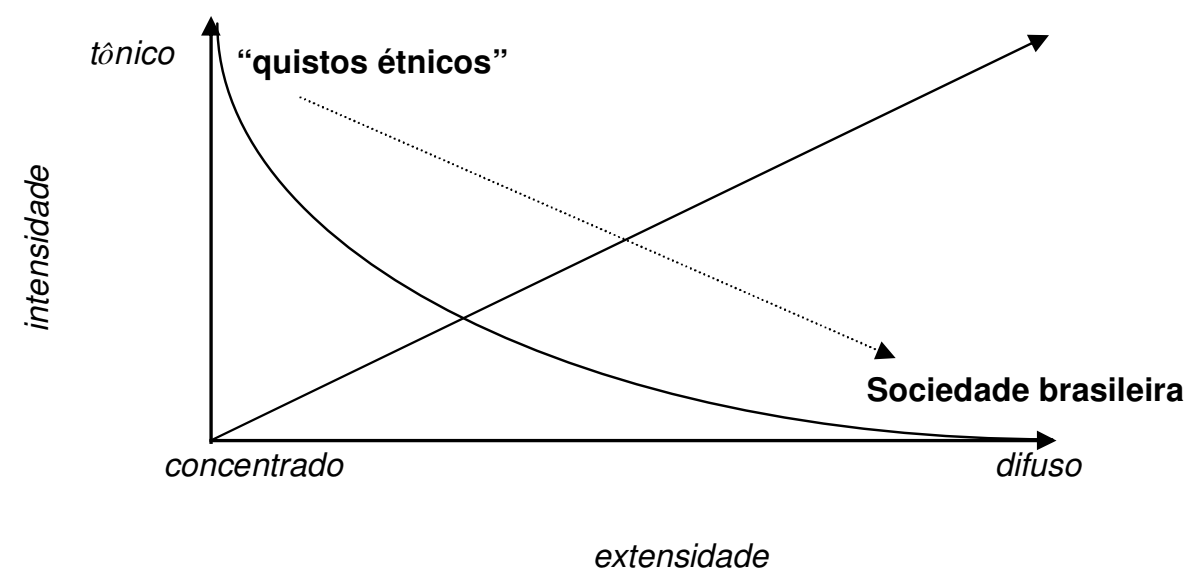

Por conta da configuração da sociedade brasileira nesses moldes, é possível pensar, segundo Reis, na assimilação do imigrante japonês. Em outras palavras, a integração do imigrante nipônico se deve, em parte, à própria configuração da sociedade brasileira, revelada pelos traços "cordiais" dos nacionais ou ao menos pela ausência de traços intolerantes que orientaram seu comportamento em relação ao estrangeiro. Dessa maneira, a unidade constitutiva do "quisto étnico" é absorvida e diluída na diversidade característica da sociedade brasileira. 
Com essa imagem da sociedade brasileira, Reis aponta ainda uma série de condições da sociedade receptora necessárias para a assimilação: a homogeneidade e a organização sociais e, como veremos, o aspecto mais importante, a de dar o tempo necessário para a integração do imigrante à sociedade. A partir dessas considerações, o enunciador apresenta fatos que indicam que a assimilação dos imigrantes japoneses já é uma realidade em certos casos:

\begin{abstract}
Nas escolas primárias, secundárias e superiores, nas profissões liberais, nas cátedras, na política, nos quartéis, nos trabalhos agrícolas, nas fábricas, repartições públicas, nas igrejas católicas e nos templos protestantes encontramos os descendentes de japoneses, apesar da evidente 'marca racial', de certo modo, identificados com os nossos hábitos, costumes e tradições, isto é, em alguns casos acomodados (quando foram apenas pressionados pelos fatores profissionais e econômicos) e noutros já assimilados pela cultura luso-brasileira (Reis, 1961: 88)

Podemos concluir, estas rápidas considerações, afirmando que a imigração nipônica apresenta um saldo positivo e favorável aos interesses nacionais porque, de modo geral, o grupo familial japonês tem orientado os seus membros no gosto pelo trabalho, pela ordem e no amor à terra brasileira que eles têm engrandecido com um labor edificante (Reis, 1961: 88).
\end{abstract}

Ao referir-se à questão racial ("apesar da evidente "marca racial'”), o enunciador mostra certa concordância com a dificuldade de assimilação do imigrante japonês por conta dessa diferença "racial" que, em certa medida, está de acordo com o seu quadro de valores (no que se refere à sua hierarquização dos imigrantes mais facilmente assimiláveis). Mesmo assim, o texto mostra que já há integração do imigrante japonês, no Brasil, e identifica, nesses imigrantes, valores que ele considera positivos, como o trabalho, a ordem e o amor ao país.

Reis se respalda novamente em um estudo de H. Saito para mostrar que a assimilação se reflete progressiva e passionalmente no imigrante japonês na medida em que ele vai aceitando que seus descendentes se insiram na sociedade brasileira por meio de casamentos exógenos:

Segundo H. Saito, a 'atitude dos pais em relação ao matrimônio de seus filhos com cônjuges de origem étnica diversa, está-se modificando rapidamente: de atitude de 'renegação terminante' de há uns dez anos passados, passou há, digamos, uns cinco anos, à de 'contrariado' e de 'constrangido', e agora, os pais mostram-se em geral, 'conformados' (Reis, 1961: 88). 
O trecho acima mostra claramente o progressivo relaxamento do imigrante japonês em relação ao casamento de seus filhos com brasileiros ou de imigrantes de fora da comunidade japonesa, sinal de que a interação e a integração passam a ser reconhecidas pela comunidade japonesa no Brasil. $O$ imigrante começa com uma postura tensa e intolerante ("renegação terminante"), passa para uma postura menos tensa (de contrariedade e de constrangimento) e, por fim, para uma posição um pouco relaxada ("conformados"). É possível que o passo seguinte seja o da aceitação, mas isso não está mencionado no texto de 1961. De certa forma, Reis (baseado no estudo de Saito) coloca esse progressivo relaxamento do imigrante japonês em relação aos seus filhos em uma perspectiva histórica.

A gradação de postura encontrada na colônia japonesa em relação à aceitação ou não da integração à sociedade brasileira é realizada, segundo Reis, pela ação dos nisseis e pela pressão da sociedade brasileira. Assim, da mesma forma que encontramos no estudo de Ruth Cardoso, Reis aponta para o papel dos nisseis no processo de assimilação dos imigrantes japoneses:

\footnotetext{
Nesse processo destaca-se o papel dos seus filhos, os 'niseis' (segunda geração) que, sofrendo o aprendizado da língua portuguesa, dos hábitos, costumes e conceitos dominantes no meio social e nos grupos sociais particulares brasileiros, levam para dentro dos lares nipônicos os nossos padrões culturais provocando, desse modo, o conflito que age como força desagregadora da cultura oriental (Reis, 1961: 87).
}

Nesse discurso, o nissei apresenta, na perspectiva da colônia japonesa, - papel de provocador da "desunião" ("conflito que age como força desagregadora da cultura oriental"), que se desdobra no tema da abertura e da consequente assimilação do japonês, do imigrante japonês que passa a viver um regime de disjunção com seus valores de origem. Dessa forma, o nissei é um sujeito que adquire os traços e valores da sociedade brasileira (como a língua portuguesa, os hábitos e costumes) para depois levá-los à sua comunidade de origem e, a partir daí, provocar a transformação do imigrante japonês em relação aos valores nipônicos.

O trecho acima mostra ainda o papel fundamental da língua no processo de transformação e de assimilação do imigrante japonês e de seus descendentes. É por meio da língua portuguesa (e também dos hábitos e 
conceitos brasileiros) que se insere na comunidade nipônica o elemento nacional que promoverá a transformação do imigrante. Mesmo com esse papel, o imigrante japonês e o nissei podem não se assimilar por completo à sociedade brasileira, segundo o ponto de vista do enunciador:

Não se pode exigir a assimilação integral do 'nisei' que permanece em contatos íntimos com seus pais ('iseis') que são os depositários da cultura de origem. No entanto, na terceira geração ('sansei') a assimilação se realiza, geralmente, de modo completo. Na quarta geração ('yonsei') está esquecida ou inteiramente abandonada a herança cultural deixada pelos bisavós (Reis, 1961: 87-88).

Como dissemos acima, Reis apresenta uma postura mais "realista" do processo assimilatório. Em outras palavras, Reis reconhece que é necessário tempo para que haja a integração total do imigrante japonês. Isso fica patente no trecho acima, ao mostrar que somente a quarta geração de descendentes de japoneses no país (yonsei) pode ser integrada completamente à sociedade brasileira.

Reis propõe, como uma etapa para a assimilação do imigrante japonês, uma política de assentamento. Nesse momento, ele retoma as já conhecidas propostas (como as do texto de Menezes Côrtes) de não se aceitar que o número de imigrantes de um único grupo seja maior do que o de brasileiros em uma determinada colônia, pois isso pode levar a uma concentração de imigrantes e a constituição de um "quisto étnico".

O texto de Reis se aproxima do ponto de vista de Menezes Côrtes e de Ruth Cardoso, ao criticar as concentrações da colônia imigrante:

Não são recomendáveis os grandes grupos que chegam, às vezes, a ser superiores, numericamente, aos dos nacionais. Em concentrações maciças de nipônicos a herança cultural estrangeira, como é óbvio, é transmitida, em sua maior parte, de gerações a gerações, muito mais facilmente, havendo, nesse caso, a reconstrução duradoura de grande parte da sociedade de origem que poderá ocasionar um estado de tensão e conflito entre a sociedade brasileira e os grupos (nesse caso) minoritários (Reis, 1961: 87).

A "concentração maciça" acima referida é, em alguma medida, a característica do "quisto étnico". Essa concentração é, como já vimos nas análises anteriores, a responsável pela manutenção das tradições e dos valores dos imigrantes, que se fecham à sociedade brasileira para 
permanecerem unidos em torno dos valores de origem, mesmo isolados no Brasil.

Essa política, evidentemente, se estende ao imigrante japonês. O autor recorre novamente a um estudo de Hiroshi Saito sobre a questão.

O Prof. Saito pondera que os japoneses deverão permanecer em pequenos grupos que permitam aos imigrados enfrentar, em comum, os choques psíquicos decorrentes da mudança para outro meio-bio-sociológico, as dificuldades econômicas e de comunicação (barreira linguística), com a sociedade dominante onde predominam 'mores' e 'folkways' muito diferentes da cultura alienígena ${ }^{137}$ (Reis, 1961: 87).

Consequentemente, uma "equação" de grupos pequenos de imigrantes japoneses diante de um número maior de brasileiros deve ser adotada como uma forma de forçar a assimilação do imigrante.

O imigrante deve estar em contato constante com a sociedade brasileira e com seu grupo de origem para evitar algum tipo de acidente (no sentido dado por Landowski, ou seja, como um desarranjo modal) na interação do imigrante em contato com a sociedade brasileira.

Em síntese, o autor aponta, em seu discurso, distâncias diferentes entre a cultura brasileira e a cultura japonesa ou a europeia, mas que a assimilação é, como dissemos possível:

\begin{abstract}
Verificou-se que, apesar de ser maior a distância existente entre a cultura japonesa e a brasileira do que entre a nacional e a europeia, os japoneses e seus descendentes, graças aos seus esforços, se enquadram no esquema da assimilação num tempo relativamente curto (Reis, 1961: 87).
\end{abstract}

Ao mesmo tempo, Reis defende que o imigrante não pode estar simplesmente sozinho na interação com os brasileiros porque assim ele não tem condições de ser assimilado, diante do choque que a diferença pode provocar (em certa medida, uma postura próxima à encontrada no estudo de Cardoso).

Por tudo o que foi dito nessa última parte de nossa análise, podemos vislumbrar o quadro de valores do enunciador. Apresentamos como os valores

\footnotetext{
${ }^{137}$ Mores pode ser entendido como "costumes folclóricos"; folkways, por conseguinte, é definido o modo de pensar de um grupo social.
} 
se organizam no texto de Reis, a partir da concepção de paradigma proposta por Zilberberg, uma vez que há a questão da distância mencionada pelo autor:

\begin{tabular}{|c|c|c|c|}
\hline S1 & S2 & S3 & S4 \\
\hline Cultura brasileira & $\begin{array}{c}\text { "Cultura } \\
\text { lusitana"138 }\end{array}$ & Cultura europeia & Cultura japonesa \\
\hline Sobrecontrário & Subcontrário & Subcontrário & Sobrecontrário \\
\hline
\end{tabular}

Com o quadro acima, é possível pensar, com o autor, que mesmo com a distância maior entre S1 e S4, é possível integrar o imigrante japonês à sociedade brasileira, graças ao grande esforço desse imigrante. Por isso, podemos dizer que é preciso mais tempo para diminuir a distância entre a cultura japonesa e a cultura brasileira e possa, assim, ocorrer a efetiva integração do imigrante japonês à sociedade brasileira. Para Reis, a assimilação dos imigrantes japoneses é possível. Basta apenas saber que o processo de integração do imigrante japonês é lento e depende também da receptividade da sociedade brasileira à alteridade.

\section{Considerações parciais}

Reis se distingue dos demais autores analisados neste capítulo por apresentar uma reflexão mais "aberta" e tolerante do processo imigratório brasileiro. Isso não significa, contudo, que seu discurso não estabeleça uma preferência pelos imigrantes de origem europeia, brancos e cristãos no momento em que estabelece uma prioridade para portugueses, espanhóis e italianos no processo imigratório brasileiro.

Mesmo assim, seu texto mostra uma visão mais otimista em relação à imigração japonesa, sobretudo pela possibilidade de assimilação do imigrante japonês e de seus descendentes à sociedade brasileira. A integração completa do imigrante japonês depende, para o autor, da adesão de diferentes gerações de descendentes de imigrantes aos valores e práticas do país.

\footnotetext{
${ }^{138}$ O termo "cultura lusitana" aparece entre aspas porque não é mencionada no fragmento acima. Essa escolha para preencher um dos espaços do paradigma foi uma opção nossa, baseada em outros discursos que mencionam a "herança lusitana" na formação cultural brasileira.
} 
Reis constrói a imagem da sociedade brasileira, como a de uma sociedade desprovida de preconceitos e de restrições a qualquer grupo imigrante. Assim, não se trata mais de elaborar o país como uma unidade dotada de sentido (como o caráter nacional, a identidade nacional, etc.), mas sim como uma totalidade que pode ser modificada (e é modificada) pela presença do estrangeiro em solo nacional.

Por isso, o texto de Reis mostra que a presença do imigrante também pode transformar a constituição da sociedade brasileira, estabelecendo que o processo de integração seja uma via dupla de transformação (a do imigrante e seus descendentes e a própria sociedade brasileira). Além do mais, seu texto enfatiza a interação entre imigrante e sociedade em termos de ajustamento (ao menos como uma primeira etapa dessa interação).

Mesmo com essa percepção da transformação mútua entre sociedade e imigrantes, o texto explicita alguns valores relacionados à imagem do imigrante ideal para o país ao apontar as características para a seleção. Como vimos, Reis estabelece uma hierarquia dos imigrantes com maiores chances de se integrar, a partir do que ele chama de "afinidades" étnicas/raciais e culturais, além da própria vontade do imigrante em ser assimilado.

\section{Conclusões do capítulo}

Neste capítulo, podemos destacar três aspectos presentes em quase todos os textos analisados: as propostas de seleção, a assimilação dos imigrantes e a construção da imagem do Brasil. Os dois primeiros aspectos estão mais ligados a propostas de política imigratória, política que serve justamente para preservar o terceiro aspecto.

Propostas de seleção estão presentes nos textos de Côrtes e de Reis. Aquele apresenta uma proposta de seleção muito mais detalhada do que este. O discurso de Côrtes promove, inicialmente, a exclusão categórica dos imigrantes de origem asiática de qualquer consideração sobre o processo imigratório no Brasil. Segundo sua justificativa, os imigrantes de origem asiática são "racialmente inassimiláveis", ou seja, são portadores de traços raciais que impossibilitam a sua assimilação. Além disso, indivíduos com problemas mentais, falta de vontade para o trabalho ou qualquer outra disfunção gerada 
pelo trauma da Segunda Guerra Mundial devem também ser excluídos do processo imigratório. Por conta disso, a imagem do imigrante ideal, construída pelo discurso de Côrtes, apresenta as seguintes características: possuidores de boa saúde, boa formação educacional, não comunistas, brancos, cristãos e aptos para o trabalho na agricultura e na indústria nacionais.

Parte desses traços é encontrada igualmente no texto de Reis. Para esse autor, o imigrante ideal é o que conta com uma boa formação educacional e apresenta traços étnicos/raciais e culturais próximos à imagem da sociedade brasileira. Sobretudo nessa questão da proximidade dos traços raciais e culturais, Reis estabelece uma hierarquia dos imigrantes mais facilmente assimiláveis, determinando que portugueses, espanhóis e italianos (e, em menor escala, árabes) são melhores para o país porque se integram com maior facilidade. No entanto, Reis apresenta uma "tolerância" em relação a outros tipos de imigrantes, como vimos no caso dos japoneses. Em outras palavras, Reis acredita que, mesmo havendo melhores imigrantes, o imigrante japonês também pode ser bom para o país.

Basicamente, a ideia da assimilação é a de fixar o imigrante no país e fazê-lo se integrar à sociedade brasileira, renegando, na medida do possível, os traços e os valores de seu país de origem. Apesar da centralidade do tema, a assimilação apresenta variações entre os três textos analisados.

De um lado, o texto de Côrtes apresenta a assimilação como solução para os possíveis problemas gerados pela presença de "quistos étnicos" no país, cuja decorrência imediata seria a ameaça à homogeneidade nacional (segurança, cultura, etc.). O texto de Reis também está em sintonia com essa concepção de assimilação encontrada em Côrtes. A diferença é que para Reis, a assimilação é um processo que pressupõe um ajustamento inicial para só depois ser pensada a assimilação. No caso de Ruth Cardoso, seu texto trata da assimilação em outra perspectiva. Por se focar em apenas um grupo, e não no imigrante em geral, a autora explica as tentativas e as dificuldades dos filhos dos imigrantes japoneses no Brasil em adquirir comportamentos brasileiros e mesmo em interagir com brasileiros. Para melhorarem, no sentido de se comportarem um pouco como brasileiros, eles procuram as associações juvenis, espaço de convívio dos nisseis que permite a prática de hábitos considerados brasileiros. 
Em relação à construção da imagem da sociedade brasileira, o texto de Côrtes, de um modo geral, mostra o processo de formação da unidade nacional, no qual se separam e excluem os imigrantes indesejáveis e se incluem os imigrantes desejáveis na constituição da sociedade nacional. Em Côrtes, os imigrantes têm ainda a função de melhorar parcela da sociedade nacional, que não apresenta o nível cultural desejado pelo enunciador. Em Reis, a imagem da sociedade brasileira é a de uma sociedade aberta, tolerante e livre de preconceitos contra os imigrantes. Ao mesmo tempo, ele entende que a sociedade brasileira está também suscetível de se transformar e melhorar com o contato dos imigrantes, de forma parecida com a que vimos em Côrtes.

De um modo geral, os três textos representam modos de se encarar a imigração e o imigrante no Brasil pós-guerra. Neles, podemos encontrar formas mais claras de preconceito (como no texto de Côrtes) e também maneiras mais difusas de preconceito (sobretudo no discurso de Reis), sobretudo pela retomada de conceitos "raciais" para estabelecer a imagem do melhor imigrante para o país. De todo modo, essas são visões presentes em um gênero talvez mais restrito, pois é voltado para o público acadêmico ou, ao menos, para um público mais preocupado com a questão imigratória no Brasil.

A seguir, veremos um gênero provavelmente mais aberto, pois tem um enunciatário "mais amplo" (isto é, a sociedade inteira). Trataremos, no próximo capítulo, de reportagens sobre a imigração no Brasil. 


\section{Notícias sobre a imigração}

\subsection{Preliminares}

Os meios de comunicação em massa são, há algum tempo, veículos que determinam valores, comportamentos, identidades e estilos de vida em uma dada sociedade. Dessa forma, rádio, televisão, revistas, jornais entre outros servem de parâmetro para indivíduos em sua busca constante por sentidos e por uma definição de identidades. Como afirma Kellner, de modo completo e incisivo:

Há uma cultura veiculada pela mídia cujas imagens, sons e espetáculos ajudam a urdir o tecido da vida cotidiana, dominando o tempo de lazer, modelando opiniões políticas e comportamentos sociais, e fornecendo o material com que as pessoas forjam sua identidade. O rádio, a televisão, 0 cinema e os outros produtos da indústria cultural fornecem os modelos daquilo que significa ser homem ou mulher, bem-sucedido ou fracassado, poderoso ou impotente. A cultura da mídia também fornece o material com que muitas pessoas constroem o seu senso de classe, de etnia e raça, de nacionalidade, de sexualidade, de "nós" e "eles". Ajuda a modelar a visão prevalecente de mundo e os valores mais profundos: define o que é considerado bom ou mau, positivo ou negativo, moral ou imoral. As narrativas e as imagens veiculadas pela mídia fornecem os símbolos, os mitos e os recursos que ajudam a constituir uma cultura comum para a maioria dos indivíduos em muitas regiões do mundo de hoje. A cultura veiculada pela mídia fornece o material que cria as identidades pelas quais os indivíduos se inserem nas sociedades tecnocapitalistas contemporâneas, produzindo uma nova forma de cultura global (2001: 9)

De toda essa longa e elegante citação, vamos reter, para nosso trabalho, a questão identitária, que envolve tanto a referência ao "nós" e ao "eles como ao senso de etnia e de raça. Assim, é preciso ver, à luz da semiótica, como os meios de comunicação de massa, e em especial a mídia impressa, constroem as relações entre identidade e alteridade, marcam suas diferenças e, por vezes, produzem ou representam casos de intolerância e de preconceito.

A semiótica pode dar sua contribuição, mesmo sem a pretensão de competir com as discussões teóricas do campo da comunicação, para o exame da mídia em geral. Como nos mostra Hernandes:

A semiótica francesa tem mostrado sua força exatamente em função de modelos de previsibilidade que nascem e são continuamente testados em práticas analíticas. $\mathrm{O}$ estudo dos textos alimenta e enriquece as reflexões 
dos semioticistas. É por isso que a teoria pode dar grandes contribuições para os estudos de comunicação, do jornalismo. Ao mesmo tempo, os jornais são um enorme desafio para a semiótica. Há muito a ser construído, não só para enfrentar antigos problemas, como ainda para encarar novíssimas questões, como as apresentadas, por exemplo, pelos sites, pela Internet, pelo cruzamento de mídias (Hernandes, 2005: 26-27).

A observação acima vai ao encontro do que Greimas afirma em seu texto "Semiótica e Comunicações Sociais". Nesse texto, Greimas mostra a especificidade da teoria semiótica em uma análise do discurso dos meios de comunicação:

Se admitirmos ainda que a dicotomia sistema vs. processo dá conta dos dois principais modos de existência de qualquer conjunto semiótico - e não apenas das línguas naturais -, veremos que essa sóciossemiótica deve encarregar-se de todos os discursos sociais, independentemente das substâncias, canais ou media que servem para suas manifestações (televisão, cinema, espetáculos esportivos coletivos, livros de figuras, etc.), principalmente porque todos eles remetem para um mesmo e único universo significante e porque as formas de organização discursiva que revelam são comparáveis (Greimas, 1981: 46).

Evidentemente, muita coisa mudou desde a publicação desse texto de Greimas. Contudo, o princípio de sua proposta permanece em bases sólidas. Mesmo em possíveis estudos que envolvam a dimensão argumentativa, sensível ou passional, entre outros, é quase impossível não passar pela questão mais profunda do sentido apontada por Greimas.

$\mathrm{Na}$ perspectiva da semiótica, podemos seguir as indicações de Hernandes. Assim, pensar no contrato entre mídia impressa e leitor é fundamental na construção e na manipulação das identidades. Segundo Hernandes, o contrato é construído, segundo o senso comum, a partir das seguintes premissas: "Dizer a verdade", "separar fatos de opiniões e interpretações", "ser objetivo e imparcial nos relatos", "mostrar a realidade" (2005: 30). Em seguida, ele utiliza os postulados da semiótica para desfazer esses mitos. O mito principal é, justamente, o da imparcialidade da imprensa, que produziria a realidade por meio de fatos objetivados e sem julgamentos. Em uma de suas análises, Hernandes mostra como os meios de comunicação de massa constroem diferentes pontos de vista a partir de um mesmo fato (2005: 37-39). 
O discurso da mídia veicula valores conservadores, para não dizer reacionários, mas também valores inovadores, progressistas, em vista de uma sociedade mais igualitária e democrática. Segundo Kellner,

A cultura da mídia pode constituir um entrave para a democracia quando reproduz discursos reacionários, promovendo o racismo, o preconceito de sexo, idade, classe e outros, mas também pode propiciar o avanço dos interesses dos grupos oprimidos quando ataca coisas como as formas de segregação racial ou sexual, ou quando, pelo menos, as enfraquece com representações mais positivas de raça e sexo (Kellner, 2001: 13).

Tratando especificamente do tema da imigração, que está envolvido diretamente na formação identitária de uma sociedade, veremos como as notícias associam a presença dos imigrantes com os temas sociais, políticos, econômicos e culturais. Esses temas são, então, usados para valorizar ou desvalorizar os imigrantes no país.

Para entender, então, como uma reportagem pode construir uma imagem positiva ou negativa dos imigrantes, podemos seguir um raciocínio próximo ao mostrado em um trabalho que analisa a forma como a intolerância é utilizada no discurso político. Como mostra Barros:

Há dois tipos de discursos políticos que usam dessa forma os discursos intolerantes. No primeiro tipo, o sujeito político constrói um éthos intolerante, de acordo com seus valores, com os de seu partido, em geral de direita, e com os de seus eleitores. Nesse caso, ele elabora um discurso de "intolerância ao intolerável", segundo esse quadro ideológico, como plataforma política. No segundo caso, o sujeito político reconhece intolerâncias da sociedade ou procura justificar e construir esses discursos sociais intolerantes para explicar e tornar aceitáveis suas ações políticas. Sem dúvida, os dois tipos de procedimentos se aproximam, pois, no segundo caso, são, geralmente, os homens políticos que já construíram, em outros discursos, uma imagem mais conservadora que farão uso da estratégia (Barros, no prelo).

A partir dessas considerações de Barros, podemos pensar que há dois tipos de reportagem que tratam da relação entre imigração e intolerância. De um lado, uma reportagem propriamente intolerante ou preconceituosa. A maneira mais fácil de se depreender isso está na forma como a reportagem representa o imigrante. De outro lado, há reportagens que não podem ser consideradas intolerantes, mas que relatam acontecimentos intolerantes envolvendo o imigrante. Em certa medida, veremos os tipos de reportagem neste capítulo. 
As reportagens a serem examinadas são as seguintes: a) "O sol também nasce no Ocidente", publicada na revista O Cruzeiro em 1958; b) "Vale a pena ser brasileiro?", publicada pela revista Realidade em 1966; c) notícias de jornais brasileiros publicadas em anos mais recentes (O Estado de S. Paulo, Folha de S. Paulo e Zero Hora).

$O$ primeiro texto é uma homenagem aos cinquenta anos da imigração japonesa no Brasil. A reportagem é permeada por histórias particulares de imigrantes e de sua relação com brasileiros. De um modo geral, a reportagem constrói uma imagem extremamente positiva dos imigrantes japoneses. No entanto, de modo esparso, apresenta uma crítica ao modo como o japonês utiliza a língua portuguesa.

A segunda reportagem critica o excesso de exigências burocráticas do processo de naturalização e mostra os prejuízos causados ao Estado brasileiro pela lei de naturalização, que impede o imigrante naturalizado de atuar em campos como a política e a burocracia estatal.

O conjunto de textos que compõe a terceira seção deste capítulo aponta diferentes situações de intolerância (linguística, inclusive) contra estudantes estrangeiros e estudantes de ascendência estrangeira mais evidente (como os de origem asiática).

\subsection{Construção da imagem positiva do trabalhador imigrante japonês: um caso de preconceito linguístico}

\section{Introdução}

Certas datas são usadas pelos meios de comunicação para a realização de efemérides de toda ordem. As comemorações podem se referir a um fato mais geral, como a Independência do Brasil, a fundação da República, ou à vida de uma personalidade importante de nossa história, como Tiradentes. Com a história da imigração, ocorre algo parecido. De um modo geral, a data da chegada da primeira leva de imigrantes de uma determinada nacionalidade passa a ser comemorada todos os anos e, quando se chega a um tempo socialmente significativo (como os 25,50 ou 100 anos de algum fato), as festividades tomam a forma de um evento excepcional. 
A revista $O$ Cruzeiro publicou uma reportagem em homenagem aos 50 anos de imigração japonesa para o Brasil em sua edição de 14 de junho de $1958^{139}$ ("O sol também nasce no Ocidente"). A reportagem cria uma imagem extremamente positiva do imigrante japonês e de seus descendentes, salientando, sobretudo, a contribuição desses imigrantes no desenvolvimento econômico brasileiro. No entanto, algumas passagens da reportagem apresentam exemplos de preconceito linguístico frequentemente associado ao imigrante japonês que interfere, em parte, na imagem positiva desse sujeito.

Veremos, inicialmente, quais as contribuições dos imigrantes japoneses ao Brasil, ressaltadas pela reportagem como uma forma de apresentar os aspectos positivos dos imigrantes japoneses em geral. Em seguida, veremos algumas histórias particulares de imigrantes japoneses que destacam as diferenças culturais entre nipônicos e brasileiros. Logo depois, examinaremos a isotopia do trabalho do imigrante japonês como o traço positivo mais destacado pela reportagem e, por fim, as considerações sobre a integração dos japoneses à sociedade brasileira e os incentivos ao aumento dessa imigração no país.

\section{As contribuições da imigração japonesa no Brasil}

A contribuição do imigrante ao país, por meio de seu trabalho, é um dos temas mais frequentes nos discursos sobre a imigração. No caso de uma reportagem, talvez por coerção do gênero, é possível tratar desse tema em um registro por vezes informal, principalmente quando comparado a uma lei ou a um artigo acadêmico. A reportagem pode, por exemplo, usar um título metafórico ou elementos não verbais em sua composição textual. Vale observar, no caso da reportagem analisada, que ela começa com um texto em japonês que é, logo em seguida, traduzido para a língua portuguesa. É a tradução que reproduzimos abaixo:

Com esta reportagem, 'O Cruzeiro' está prestando sua homenagem à colônia japonesa do Brasil, pelo meio século de imigração que, de mãos enlaçadas com as nossas, nestes dias comemora. Em junho de 1908 chegava às terras brasileiras o primeiro contingente de imigrantes do Japão; em junho de 1958 relembramos aquele primeiro grupo para dizer-lhe uma única palavra pelo

\footnotetext{
${ }^{139}$ A data oficial de início da imigração japonesa é 18 de junho de 1908 , quando chegou ao porto de Santos o navio Kasato Maru.
} 
caminho que abriu: obrigado. Não fossem os que chegaram há 50 anos e hoje talvez não pudéssemos publicar esta reportagem que se escreve em números e dados, mas também em sentimentos, porque nela se conta o muito, o inacreditável quase, que os japoneses têm feito pelo desenvolvimento econômico do Brasil. Nossa alegria é que tivemos participação ativa nessa lição de fraternidade que, juntos, hoje podemos transmitir ao mundo. Nosso pesar é não poder publicar em caracteres japoneses, para os nossos irmãos novos que ainda não leem o português, tudo quanto se conta nestas páginas. $A$ esses dedicamos estas palavras. A eles, aqui fica o nosso agradecimento (Pagote e Moraes, 1958: 21).

Alguns temas que serão desenvolvidos pela reportagem já estão presentes nesse fragmento: o reconhecimento da contribuição que os imigrantes deram na esfera econômica; a questão da fraternidade brasileira; e a questão linguística. Além disso, o fragmento acima indica também as duas formas de "comportamento" da reportagem: de um lado, com um efeito de objetividade e formalidade (por meio de "números e dados"), isto é, de razão, e, de outro, com um efeito de subjetividade e informalidade (por meio dos "sentimentos"), representativos da dimensão passional da reportagem. São esses dois termos que, juntos, definem a reportagem e são destacados em nossa análise, indo da razão à paixão suscitada pela presença dos imigrantes japoneses no Brasil e pela forma como se definiu a relação desse grupo estrangeiro com a sociedade brasileira.

O fragmento acima apresenta traços de um discurso reverente ao imigrante japonês, com dois agradecimentos e uma expressão quase exacerbada sobre a contribuição do imigrante japonês para o desenvolvimento econômico do Brasil. Ao mesmo tempo, no plano sociocultural, há o tema da fraternidade brasileira, no qual se ressalta 0 acolhimento e a bondade dos brasileiros em relação aos imigrantes japoneses. Além do mais, a fraternidade é reiterada no momento em que os autores da reportagem se referem aos imigrantes japoneses como "nossos irmãos novos". Veremos na seção referente a algumas histórias de imigrantes japoneses como a reportagem constrói uma relação quase familiar entre os imigrantes e os brasileiros.

Em relação à língua, há uma imagem associada ao imigrante japonês que não sabe ler em português. Esse tema está relacionado, de certa forma, com o tema da fraternidade brasileira porque há um pesar por não se poder publicar toda a reportagem em japonês. Mesmo assim, a reportagem apresenta 
a introdução em japonês como uma forma de diminuir a distância entre os japoneses que não sabem a língua portuguesa e o tema que ela trata.

Os mesmos temas do fragmento acima continuam presentes no primeiro parágrafo da reportagem, com a exceção da questão linguística, que foi substituída por um maior desenvolvimento da isotopia histórica. A dimensão histórica é traduzida na forma de dados estatísticos, como o número de famílias e pessoas que vieram no primeiro navio japonês, na participação dos imigrantes japoneses na agricultura brasileira, objetivando e racionalizando, assim, a experiência histórica por meio de números:

Quatrocentos mil brasileiros de olhos oblíquos, alguns deles nascidos no longínquo Império do Sol Nascente, estão em festa, comemorando o $50^{\circ}$. Aniversário do início da imigração japonesa para o Brasil. Exatamente há meio século, a 18 de junho de 1908, pelo navio 'Kassado Maru', chegavam a Santos os primeiros imigrantes: 158 famílias, num total de 781 pessoas. Nesses cinquenta anos, a colônia aumentou e prosperou, contribuindo de forma decisiva para o desenvolvimento do País, especialmente no setor agrícola. Hoje em dia, constituindo apenas $0,7 \%$ da população brasileira, a colônia nipônica produz $40 \%$ do algodão e $10 \%$ do café, do arroz e do milho colhidos no País. Por outro lado, $95 \%$ dos tomates, $90 \%$ dos ovos, $70 \%$ das hortaliças, $60 \%$ das batatas e $50 \%$ das bananas consumidas no Brasil provêm de granjas e fazendas dirigidas por japoneses ou seus descendentes. O Brasil nunca erigiu nenhum monumento ao trabalhador nipônico. Em São Paulo e no Paraná, entretanto, as zonas pioneiras que eles cultivaram e as dezenas de cidades que eles plantaram em regiões até então cobertas de matas virgens são o melhor atestado da excelência desse imigrante. Os quatrocentos mil brasileiros de olhos oblíquos, tanto quanto os antigos bandeirantes, tornaram o Brasil maior e mais rico (Pagote e Moraes, 1958: 21).

Os dados estatísticos servem para comprovar, no discurso, que o imigrante japonês é um trabalhador competente e, principalmente, que seu trabalho auxiliou no desenvolvimento econômico do país. Além disso, mesmo sem o reconhecimento oficial do governo brasileiro, o produto do trabalho do imigrante japonês é considerado "o melhor atestado da excelência desse imigrante", segundo o ponto de vista dos jornalistas.

No trecho acima há também crítica ao governo brasileiro por ele não reconhecer a contribuição do imigrante japonês ("O Brasil nunca erigiu nenhum monumento ao trabalhador nipônico"). A reportagem apresenta uma crítica implícita ao trabalhador brasileiro no momento em que se aponta o japonês, mesmo estando em pequeno número se comparado à sociedade brasileira, como uma presença predominante na produção de diversos produtos do mercado brasileiro. Veremos, abaixo, como essa crítica implícita esta 
relacionada, em certa medida, com a questão do medo da sociedade brasileira por causa da alta produtividade dos imigrantes japoneses.

O trecho acima apresenta uma sanção positiva sobre o /fazer/ do imigrante japonês no Brasil. Mas essa sanção recai, principalmente, no fato de os imigrantes japoneses serem "poucos que fazem muito". Em outras palavras, o destinador-julgador percebe que o imigrante japonês faz mais do que qualquer trabalhador (brasileiro ou imigrante) e, por isso, o sanciona positivamente.

Outro aspecto que chama a atenção nesse fragmento está na forma como os jornalistas se referem ao imigrante japonês: "brasileiros de olhos oblíquos". Entendemos que essa forma metonímica de se referir ao imigrante japonês é uma forma de apresentá-los como brasileiros de outro modo ${ }^{140}$, reforçando a fraternidade brasileira em relação aos nipônicos. Essa forma mais próxima e relaxada de se referir ao imigrante japonês contrasta com o tom mais formal e reverente do fragmento escrito em japonês e traduzido para a língua portuguesa. A forma mais "íntima" está presente em toda a reportagem, sobretudo nos momentos em que conta alguns fatos mais curiosos sobre a vida de alguns imigrantes japoneses.

O trecho acima mostra, ainda, que esses "brasileiros de olhos oblíquos" estão também comemorando a data. Esse traço de "felicidade" serve para mostrar que os japoneses estão satisfeitos por estarem no Brasil. Consequentemente, podemos entender que essa felicidade advém também do bom tratamento dado ao imigrante japonês pela sociedade brasileira, que seria desprovida de preconceitos, como veremos adiante. Além disso, esse traço pode camuflar os problemas que os imigrantes japoneses tiveram quando foram acusados, em diversos discursos, de se fecharem em comunidades e não interagirem com os brasileiros.

O tema da fraternidade brasileira é retomado no trecho abaixo. A reportagem mostra que os primeiros anos de imigração japonesa tinham por objetivo final a ida para o Havaí. Somente após a proibição da entrada de japoneses nos EUA, o objetivo passou a ser o Brasil:

\footnotetext{
${ }^{140}$ Em outros textos (de cunho mais racial), a diferença ressaltada pode ser a cor da pele, por exemplo. A questão é que, quando se trata de mencionar o imigrante de origem asiática, algum aspecto de sua composição física é ressaltada para marcar uma diferença com os brasileiros.
} 
Os últimos imigrantes foram praticamente contrabandeados, pois logo depois da anexação do Havaí o governo norte-americano adotou uma legislação imigratória que não permitia a entrada de japoneses no país. Foi exatamente nessa época, como se vê, que os japoneses voltaram-se para a América do Sul (Peru e Brasil), onde a inexistência de preconceitos raciais ou religiosos thes assegurava uma vida tranquila (Pagote e Moraes, 1958: 23)

O trecho acima menciona a ausência de preconceito racial ou religiosos na América do Sul e, principalmente, no Brasil. A reportagem constrói, assim, a representação de um país adequado para se ter uma vida tranquila. $\mathrm{O}$ fragmento reforça um dos traços da imagem da identidade nacional ao realçar o caráter brasileiro de povo receptivo, solidário e desprovido de preconceitos, cujo maior exemplo da reportagem está no brasileiro que auxiliou Kudama quando estava perdido e abandonado no Rio de Janeiro.

A reportagem propriamente dita é dividida em pequenas seções e está repleta de histórias particulares (e muitas vezes "causos") em que aparece, em algumas delas, a questão linguística. É justamente nesses casos que a figura do imigrante japonês deixa de ser reverenciada para ser, de certa forma, satirizada. Veremos, a seguir, essas histórias particulares do imigrante japonês no Brasil, que ressaltam as diferenças culturais entre japoneses e brasileiros.

\section{Histórias pessoais da imigração japonesa: estereótipos, diferenças culturais e linguísticas}

Uma das formas de se compreender o tratamento mais relaxado e informal dado à imagem do imigrante japonês ocorre por meio de um efeito de realidade, a partir da iconização dos japoneses. Parte da reportagem é feita, nesse caso, pelo relato da história particular de alguns imigrantes japoneses. Consequentemente, essa parte da reportagem apresenta situações inusitadas envolvendo a interação entre japoneses e brasileiros.

A reportagem começa com o relato dos primeiros imigrantes japoneses no Brasil, que chegaram em abril de 1906, ou seja, antes mesmo do início da imigração japonesa, que começou em 1908. Assim, ela informa que dois imigrantes aportaram no Brasil em 1906 e que eles foram recepcionados por Carlos Botelho, secretário da agricultura do governo paulista. A reportagem 
menciona também famílias que vieram por conta própria, antes da organização do processo imigratório japonês (Pagote e Moraes, 1958: 22).

Além dessas histórias, os jornalistas se detêm na história de três amigos que decidiram vir para o Brasil, depois de o navio em que viajavam ter parado no porto de Liverpool (onde outros imigrantes japoneses desembarcaram). Depois de desembarcarem no porto do Rio de Janeiro, Yassuda, Kudama e Nagasi tomaram o trem a caminho de São Paulo. Enquanto todos esperavam a partida do trem já dentro do vagão, um deles (Kudama) saiu para comprar pão e, então, perdeu o trem, como podemos ver no seguinte trecho:

À noitinha, a fome apertou e Kudama desceu para comprar pão. Antes de voltar, todavia, o trem partiu, levando os desesperados Yassuda e Nagasi, que choravam com pena do amigo. Kudama também chorou muito, até que resolveu dormir num banco da praça da República, onde ficou até à hora do fechamento dos portões (Pagote e Moraes, 1958: 22).

Há dois aspectos que queremos reter desse fragmento. O desespero dos dois imigrantes que permaneceram no trem quando este partiu sem 0 amigo deles e o fato de todos os três terem chorado. Parece-nos que há um realce das diferenças culturais do imigrante japonês em relação ao comportamento mais visto de trabalhadores imigrantes ${ }^{141}$. O fato de esses imigrantes ficarem desesperados e chorarem a perda do amigo nos faz pensar, ainda, que há uma imagem implícita (não necessariamente negativa) que infantiliza o imigrante japonês e que retoma a referência aos imigrantes feita anteriormente em outro fragmento ("nossos irmãos novos").

A reportagem prossegue com o relato da situação inesperada vivida por Kudama e a sua resolução:

O japonês, então, acomodou-se fleumaticamente sob uma árvore, em frente à Central, até que um brasileiro - Evaristo de Moraes - passou pelo local e o levou para casa, onde deu-lhe comida e, no dia seguinte, embarcou-o para São Paulo. O que nunca se soube - é como os dois se entenderam (Pagote e Moraes, 1958: 22).

\footnotetext{
141 Essa postura mais passional (e também passiva) contrasta com o sentimento de orgulho e de superioridade apontado no estudo de Ruth Cardoso (analisado no capítulo anterior). Além do mais, a postura passional também se opõe à imagem do imigrante como trabalhador, ou seja, como um sujeito do /fazer/ que teria pouco tempo para sentimentos, como veremos adiante.
} 
O tema da fraternidade brasileira é retomado nesse fragmento pela ação do brasileiro que acolhe, dá comida e, depois, embarca o imigrante japonês perdido para São Paulo. A ajuda do brasileiro ao japonês ocorre, como o texto mostra, sem os dois se entenderem linguisticamente, o que, de certa forma, mostra que a fraternidade brasileira ultrapassa os limites impostos pelas diferenças linguísticas. A fraternidade, nesse caso, pode ser entendida como uma forma de contágio, tal como definida por Landowski. Mesmo sem se compreenderem, o brasileiro pode ajudar o imigrante japonês por colocar-se, de certa forma, na posição de Kudama e, assim, sentir suas dificuldades naquele momento.

Os dois amigos de Kudama chegaram a São Paulo e também encontraram problemas: sem conseguir se comunicar e "sem compreender direito o que se passava", Yassuda e Nagasi foram levados a um hotel por um carregador de malas. Quando chegaram ao hotel, eles ficaram nervosos (porque queriam permanecer na estação de trem, esperando Kudama) e começaram a gritar no saguão do hotel até a dona do local chegar e chamar Sakuma ${ }^{142}$, que trabalhava na "Casa Japão em São Paulo" (filial de uma empresa japonesa). Como reportagem diz, "Sakuma já arranhava um pouco o português e, no dia seguinte, com Yassuda e Nagasi, recebeu o transviado Kudama" (Pagote e Moraes, 1958: 23). O verbo "arranhar" é uma metáfora que permite duas possibilidades de interpretação: a primeira, a de que o imigrante japonês conhece pouco a língua portuguesa; a segunda, a de que ele machuca a língua. De qualquer forma, essas duas possibilidades de entendimento mostram o tratamento informal dado ao relato da "aventura" dos imigrantes japoneses recém-chegados.

O aspecto linguístico fica evidente nessas duas situações relatadas pela reportagem: mesmo com a incompreensão linguística, a primeira situação foi resolvida pela tolerância e solidariedade de um brasileiro (no caso de Kudama) que ajudou o imigrante japonês, mesmo sem compreender a língua do outro. $A$ segunda situação (a do hotel) foi solucionada porque a dona do hotel chamou um japonês que conhecia um pouco o português e, assim, pode acalmar os dois japoneses.

\footnotetext{
${ }^{142}$ Sakuma é um sobrenome japonês. A reportagem não deixa claro se está se referindo a um homem ou a uma mulher.
} 
Outra história retoma a questão das diferenças culturais. A história é sobre a primeira luta de jiu-jitsu disputada no Brasil e que ocorreu entre o lutador Sack Miura e um capoeirista não identificado: quando a luta começou, o capoeirista começou a gingar e tocou suas mãos no solo. Miura, que nunca tinha visto um capoeirista, entendeu esse gesto como uma forma de cumprimento e tratou de retribuí-lo. Ao fazer isso, ele recebeu um golpe e só retomou sua consciência no pronto-socorro (Pagote e Moraes, 1958: 23). Essa história foi contata por Yassuda ${ }^{143}$, que é assim apresentado pela reportagem:

Como a maioria dos seus patrícios que vieram para o Brasil, Rioiti Yassuda é um brasileiro autêntico, tão brasileiro quanto os seus seis filhos que aqui nasceram. Antigo líder rural do Partido Democrático e do Partido Constitucionalista, foi um dos fundadores do efêmero Partido da Lavoura e da União Democrática Nacional. Entre outras coisas, foi funcionário do Ministério da Agricultura, quando organizou um Horto Florestal em Maceió e plantou 30 mil eucaliptos no Rio Grande do Sul. Das autoridades brasileiras, Yassuda recebeu uma prova de reconhecimento pela vida inteira que dedicou ao Brasil: durante a guerra, a Polícia invadiu sua residência para apreender um sabre histórico que pertencera ao Barão de Itapeva e que lhe fora presenteado pela Baronesa (Pagote e Moraes, 1958: 23) ${ }^{144}$.

Esse fragmento apresenta Yassuda como um brasileiro nato, mostrando, em um registro mais formal, suas realizações como político e funcionário público. Mesmo não sendo citado explicitamente, Yassuda aparece como o exemplo perfeito do imigrante que se adaptou ao país e se tornou bem sucedido. Na descrição dos feitos de Yassuda, o que prevalece é o efeito de formalidade, de objetividade e de respeito.

Na última parte do trecho acima, há novamente uma crítica ao governo brasileiro feita em tom irônico. O "reconhecimento" do governo brasileiro foi realizado com uma invasão da polícia na casa de Yassuda, que teve seu sabre, um presente da Baronesa de Itapeva, apreendido. Em outras palavras, o "reconhecimento" mencionado pela reportagem foi, na verdade, o roubo de um objeto de valor sentimental e financeiro do imigrante japonês. Esse acontecimento, nos parece, ocorreu durante a Segunda Guerra Mundial.

\footnotetext{
${ }^{143}$ Esse é o mesmo Yassuda da história anterior.

${ }^{144}$ Não encontramos qualquer referência, na possível legislação vigente naquele momento (Constituição de 1891, 1934 e 1937 e Código Civil de 1916), à autorização ou à proibição da participação de estrangeiros, naturalizados ou não, em partidos políticos ou cargos políticos públicos (legislativo e executivo). De qualquer forma, as duas Constituições e o Código Civil mencionados permitem, a brasileiros e estrangeiros residentes no país, a liberdade de associação. Por isso, entendemos que não havia qualquer tipo de problema com o fato de Yassuda ser estrangeiro e participar de partidos políticos.
} 
A atuação política de imigrantes japoneses foi também relatada pela reportagem a respeito do lutador de jiu-jitsu da história acima. Miura foi editor do jornal Nippak Shimbun, que se colocou contra o "totalitarismo nipônico e a ditadura brasileira, o que Ihe valeu ser expulso do País". Nesse caso, a expulsão do país é sancionada positivamente pela reportagem porque o Brasil vivia o regime ditatorial de Getúlio Vargas e Miura o enfrentou. Dessa forma, ser punido com a saída compulsória do Brasil é algo positivo para a reportagem porque o realizador da expulsão era visto negativamente (a ditadura de Vargas).

Ainda segundo a reportagem, Miura foi o precursor de "toda uma geração de brilhantes jornalistas 'niseis', dentre os quais se destacam hoje Hideo Onaga, chefe de reportagem das 'Folhas' de São Paulo, e José Yamashiro, da Revista 'Visão'” (Pagote e Moraes, 1958: 23). Dessa forma, o trecho mostra a contribuição que os imigrantes japoneses também deram no combate à ditadura do país (a ditadura Vargas) por meio da atividade jornalística.

Esse trecho laudatório a respeito de jornalistas descendentes de japoneses também aparece com um tom mais formal, ao contrário do tom mais relaxado encontrado na história da luta do próprio Miura. Além disso, em ambos os trechos (o de Yassuda e o de Miura), as reportagens mostram que os dois imigrantes tiveram problemas com o Estado brasileiro durante a Era Vargas. A reportagem constrói uma crítica ao governo brasileiro em geral, seja pelas restrições impostas aos imigrantes durante a Segunda Guerra Mundial, seja pela falta de reconhecimento ao trabalho do imigrante japonês no Brasil. De alguma forma, mesmo com essas restrições e com a falta de reconhecimento, os imigrantes japoneses foram, segundo a reportagem, muito bem sucedidos em sua empreitada no Brasil.

Vimos, nesta seção, a construção positiva da imagem do imigrante japonês, principalmente na esfera do trabalho. Mas a reportagem mostra também a atuação política do imigrante japonês no país e a forma como ele se contrapôs, em alguns casos, à ditadura de Vargas. Ao mesmo tempo, a reportagem apresenta as diferenças culturais entre japoneses e brasileiros de uma forma que pode ser entendida como irônica e ainda uma sutil crítica ao modo como o japonês usa a língua portuguesa. Além disso, a reportagem 
procura diferenciar a solidariedade e a fraternidade dos brasileiros da hostilidade e da falta de reconhecimento por parte do Estado Nacional.

Veremos, na próxima seção, como a reportagem trata, de modo laudatório, a contribuição do imigrante japonês ao desenvolvimento econômico nacional.

\section{A isotopia do trabalho dos imigrantes japoneses e a construção de estereótipos}

A história da imigração mostra, frequentemente, que os imigrantes são, independente de sua origem, considerados bons trabalhadores. No caso da presente reportagem, há uma diferenciação do trabalho do imigrante japonês que pode ser entendida como uma intensificação do seu /fazer/. Veremos, assim, como esse imigrante contribuiu para o desenvolvimento econômico nacional e como sua imagem de trabalhador é construída.

Para realizar seu /fazer/, o imigrante japonês procurou eliminar possíveis dificuldades presentes no ambiente em que se instalou. É por isso que, além do trabalho na agricultura, outro aspecto realçado na reportagem se refere aos benefícios produzidos nas regiões ocupadas pelos imigrantes japoneses advindos da adaptação promovida por eles:

\footnotetext{
Demonstrando magníficas condições de adaptação ao meio ambiente, os colonos nipônicos sanearam regiões insalubres e edificaram os fundamentos de cidades que hoje em dia são monumentos vivos ao seu pionerismo. Marília, Bastos, Presidente Prudente, Tupã, Suzano, Mogi das Cruzes e inúmeras outras localidades paulistas não apresentariam hoje os mesmos índices de progresso não fora o braço japonês (Pagote e Moraes, 1958: 24).
}

O tema da adaptação do imigrante ao espaço físico é um dos traços apresentados nesse fragmento, o que de certa forma é uma retomada da adaptação social apresentada pela história de Yassuda. A adaptação acima mencionada teve como consequência o desenvolvimento de várias cidades do estado de São Paulo. Inclusive, retomando o tema do trabalho, o texto afirma que essas cidades não apresentariam o desenvolvimento que têm se não fosse o trabalho do imigrante japonês. Dessa forma, a reportagem mostra que os imigrantes japoneses são trabalhadores competentes o suficiente para 
transformar o ambiente em que se instalaram, tal como se construíssem um novo objeto-valor.

A reportagem mostra ainda outro traço que diferencia o trabalhador japonês dos demais trabalhadores:

Produzir é a obsessão do imigrante japonês. Cerca de $75 \%$ da colônia fixaramse em São Paulo, $20 \%$ no norte do Paraná, 3\% espalharam-se por Mato Grosso, Minas, Goiás, Rio de Janeiro e Rio G. do Sul, enquanto os restantes $2 \%$ escolheram o Amazonas e o Pará, onde introduziram o cultivo da juta e da pimenta-do-reino, cuja produção já supre nosso mercado interno (Pagote e Moraes, 1958: 24).

A imagem do imigrante japonês no trecho acima não é apenas a de um trabalhador comum, mas a de um obsessivo trabalhador que não se conforma apenas ao que tem que fazer. Trabalhar ao máximo significa sempre aumentar (mais mais ${ }^{145}$ ) a sua produção, traço que seria característica do trabalhador japonês.

A obsessão pode ser entendida como uma paixão iterativa, orientada por um /querer-ser/ que leva à repetição do /fazer/ na construção de seu objeto valor. No caso, a obsessão pelo trabalho do imigrante japonês o diferencia dos demais trabalhadores (brasileiros e imigrantes) justamente por esse /fazer/ repetitivo que nunca cessa e o transforma, assim, em um trabalhador melhor do que os outros.

Uma das consequências dessa obsessão pelo trabalho encontra-se no trecho abaixo. A reportagem enfatiza a contribuição do imigrante japonês no desenvolvimento econômico de certas regiões brasileiras, como o caso do estado do Paraná:

E o dinamismo que possibilitou ao norte do Paraná um desenvolvimento tão rápido, não é senão em consequência do alucinante ritmo de trabalho do imigrante japonês. Não se contentando em intensificar sensivelmente a cultura dos produtos básicos da nossa economia, os japoneses ainda introduziram no País a cultura de muitos produtos novos, tais como seda natural, hortelã, rami, tungue, frutas e hortaliças das zonas temperadas, juta, chá e pimenta-do-reino (Pagote e Moraes, 1958: 24).

145 O operador "mais mais" é uma das modulações possíveis no espaço criado pelo esquema tensivo. De um modo geral, ele representa um acréscimo de intensidade em um percurso ascendente que leva a constituição de uma unidade (Zilberberg, 2006: 212-213). 
Esse fragmento mostra que há, de um lado, uma aceleração econômica considerada normal (como a de qualquer trabalhador) e, de outro, uma aceleração econômica mais do que o normal, que é a do trabalhador japonês.

O imigrante japonês, segundo a reportagem, é também um inovador em sua atividade. Assim, ele inova ao introduzir o cultivo de novos produtos agrícolas. Dessa forma, podemos entender que a inovação é a produção de um objeto que não era esperado. Por essa razão, esse objeto passa a ser único e exclusivo, ou seja, uma particularidade do imigrante japonês em relação ao trabalhador brasileiro (e talvez aos demais imigrantes).

A reportagem cita a produção industrial japonesa no Brasil, assim como empresas nacionais fundadas por imigrantes japoneses, dentre elas a Cooperativa Agrícola de Cotia (CAC). Segundo a reportagem, a CAC foi a principal responsável por fazer com que o tomate deixasse de ser um produto dos mais ricos, democratizando seu consumo com preços mais acessíveis a toda a população (Pagote e Moraes, 1958: 24) ${ }^{146}$ :

Acompanhando o ritmo de industrialização do Brasil, os japoneses já não se dedicam apenas à agricultura. No setor da tecelagem, a Fiação Extra-Fina de Algodão e a Tecelagem Kaneko reunem um capital de 150 milhões; a Indústria Mecânica Howa (120 milhões) fabrica teares; a Superfine (21 milhões), peças para máquinas de costura; a Indústria Doi-Maruei (22 milhões), porcelanas; a Yannar Diesel (17 milhões), motores; a Ajinomoto empatou 7 milhões da fabricação de condimentos e a Pilot Pen, 13 e meio milhões na produção de canetas. Isso sem falarmos na Taiyo Fishery, que veio inaugurar a indústria de pesca no País e transformar em realidade a pesca e a industrialização de baleia na Paraíba, e no império econômico da Casa Tozau, os Rockfellers do Japão (Pagote e Moraes, 1958: 24).

Outra forma de colaboração dos imigrantes japoneses à sociedade brasileira está presente nas doações feitas pela comunidade nipônica para reforma de sanatórios e de asilos brasileiros. Além disso, segundo a reportagem, a organização da festa dos 50 anos de imigração japonesa no Brasil arrecadou um montante (por meio de doações da comunidade) que seria repassado para o Hospital Franco da Rocha (Pagote e Moraes, 1958: 24). Dessa forma, o imigrante japonês também é caracterizado por ser generoso e por auxiliar a sociedade brasileira.

\footnotetext{
${ }^{146}$ Segundo Lesser, o governo de Juscelino Kubitschek (em vigência no momento de publicação dessa reportagem) incentivou os investimentos japoneses no Brasil. Assim, empreendimentos entre o Brasil e o Japão foram responsáveis pela criação da Usiminas e do estaleiro Ishibrás, no Rio de Janeiro (2008: 47)
} 
O /fazer/ do imigrante japonese tem, então, duas consequências diretas: a primeira, a de contribuir com o desenvolvimento econômico nacional; a segunda, a de criar facilidades para a sociedade brasileira (seja por meio da inclusão de novos produtos ou o seu barateamento seja por meio de doações aos mais carentes).

A reportagem constrói uma imagem tão elogiosa do imigrante japonês, construída como a de trabalhadores competentes e indivíduos generosos, que é possível, em outros discursos, criar uma postura de ressentimento (e até de intolerância) em relação ao trabalhador japonês, por induzir o brasileiro a se sentir inferior e incompetente. Esse efeito pode, inclusive, afetar trabalhadores imigrantes de outra origem também. Dessa forma, fica implícita uma crítica ao trabalhador nacional, que não apresenta a mesma competência para produzir como os imigrantes japoneses. Ainda em relação à sociedade brasileira, o único traço valorizado é, como vimos, a fraternidade.

Veremos na próxima seção como a fraternidade da sociedade brasileira pode ser considerada, ao menos segundo a reportagem, como um dos fatores responsável pela integração do imigrante japonês à sociedade nacional.

\section{A assimilação dos imigrantes e o incentivo a sua entrada no país}

A imagem positiva do imigrante japonês no tema do trabalho encontra sua contrapartida no tema da assimilação. A despeito de algumas divergências de ordem cultural, a parte final da reportagem aponta como os japoneses se assimilaram ao contexto social brasileiro. Para isso, a reportagem apresenta alguns exemplos:

Depois da guerra, a aculturação dos japoneses processou-se em ritmo acelerado e deixou de existir o problema dos quistos raciais nipônicos. As universidades estão cheias de 'niseis' que, de oriental, possuem apenas os olhos oblíquos. Em todos os setores da vida brasileira, inclusive na política, os imigrantes nipônicos e seus descendentes participam ativamente. Alega-se com frequência que os japoneses fazem questão de se reunir em grupos fechados para o desempenho de atividades artístico-culturais. Em primeiro lugar, esses grupos não são fechados. E, em segundo lugar, uma forma magnífica de demonstrar sentimento de brasilidade é introduzir no nosso meio os elementos de uma cultura milenar que sempre causou inveja ao Ocidente. $O$ Deputado João Sussumu Hirata constatou que a grande maioria de japoneses budistas ou sintoistas estão batizando seus filhos em igrejas cristãs. Que maior demonstração de boa vontade pode dar um imigrante quando sacrifica sua crença pessoal em favor da religião predominante no país que adotou como 
pátria? Já é tempo de o Instituto Nacional de Imigração e Colonização compreender a desvantagem de insistir na vinda para o Brasil de desajustados $^{147}$ que somente têm contribuído para agravar os nossos problemas urbanos. Em vez de persistirmos numa política imigratória errada, intensifiquemos a vinda de imigrantes japoneses. Eles, como registra o anedotário popular, estropiarão o idioma português, mas não há a menor dúvida de que estenderão por todo o Brasil, o milagre de São Paulo e do Paraná (Pagote e Moraes, 1958: 24-26).

A reportagem retoma a ideia de que os imigrantes japoneses tinham a tendência a se isolar da sociedade brasileira. $O$ fragmento dá uma série de exemplos para contradizer esse outro discurso. Mesmo assim a reportagem mostra que ainda há discursos que afirmam que a colônia japonesa é fechada e isolada do restante da sociedade brasileira. Em relação aos quistos étnicos, vemos o mesmo movimento encontrado no estudo de Ruth Cardoso: de um estágio fechado, a colônia japonesa passa a uma abertura em direção à sociedade brasileira. Essa abertura é representada pela participação dos imigrantes e de seus descendentes em esferas predominantemente ocupadas por brasileiros (como a universidade, a política e a religião). Dessa forma, o imigrante japonês se mostra disposto ("boa vontade") a interagir com os brasileiros porque quer ser considerado também um brasileiro (tanto que dá nomes "ocidentais" para seus filhos nascidos no Brasil, além de batizá-los na igreja católica).

A abertura da colônia só pode se concretizar porque a sociedade brasileira acolheu bem os japoneses. Para os repórteres, a existência da colônia japonesa (que não é fechada, segundo a reportagem) é uma prova da tolerância à diversidade, que possibilita a interação entre brasileiros $\mathrm{e}$ japoneses. Entendemos que essa valorização da diversidade na sociedade brasileira é responsável pelo "sentimento de brasilidade" presente no próprio imigrante japonês, que, assim, pode inserir no Brasil elementos da "cultura milenar" nipônica. Assim, mais uma vez o tema da fraternidade brasileira aparece na reportagem: a abertura da colônia e a presença de elementos culturais japoneses faz com que os brasileiros conheçam a cultura do outro e pode, então, se beneficiar desse contato em solo nacional. Por ser, então, um país tolerante, o Brasil deve, segundo a reportagem, incentivar mais a

\footnotetext{
${ }^{147}$ Quando a reportagem menciona os “desajustados", ela está se referindo aos refugiados e deslocados de guerra.
} 
imigração japonesa do que a europeia (constituída por deslocados de guerra), mesmo com o risco de se "estropiar" a língua portuguesa.

A questão linguística acima mencionada faz parte de um discurso presente na sociedade e a reportagem parece concordar com ele. A questão linguística é tratada como algo pouco grave e, por isso, mesmo com esse "problema", a imigração japonesa deveria ser mais incentivada por causa do trabalho realizado pelo japonês. $O$ fato de o japonês "estropiar" a língua portuguesa é um problema menor e, por isso, não precisa ser considerado um índice pertinente de aculturação/assimilação do imigrante japonês e de seus descendentes no Brasil. A língua é, assim, relegada a um segundo plano - o das anedotas -, enquanto o plano mais prático é usado para a construção positiva da integração do imigrante japonês à sociedade brasileira.

\section{Conclusões parciais}

Em relação ao discurso dessa reportagem, podemos observar três temas predominantes:

- a fraternidade brasileira desprovida de preconceitos;

- o trabalho do imigrante japonês, que contribui para o desenvolvimento econômico nacional;

- o das diferenças culturais, representadas por algumas histórias particulares e pela incompreensão linguística.

O texto analisado oscila entre uma imagem extremamente positiva do trabalho japonês e um preconceito linguístico, ambos mediados pela imagem de uma sociedade supostamente fraterna e sem preconceitos. Nesse ínterim, a reportagem também critica o governo brasileiro por não incentivar e facilitar a entrada de mais trabalhadores japoneses e por não reconhecer as vantagens que tal presença geraria para o país.

O discurso, assim, valoriza os dois primeiros temas em detrimento do terceiro. Dessa forma, o que interessa é aproveitar o que o imigrante japonês pode fazer em relação ao desenvolvimento econômico brasileiro, mesmo que a língua portuguesa seja "sacrificada".

A imagem do imigrante japonês é construída, por um lado, hiperbolicamente: eles são muito dedicados ao trabalho ou são mesmo 
obsessivos em relação ao trabalho. Por outro lado, a metonímia é usada para mostrar o imigrante japonês como um brasileiro "diferente", mas ainda assim brasileiro.

Em relação aos regimes de interação, podemos observar um predomínio da programação: reforça-se assim o estereótipo do imigrante japonês trabalhador e que possui dificuldades com a língua portuguesa. Ao mesmo tempo, o tema da fraternidade brasileira é compreendido como um ajustamento feito pela sociedade para receber o imigrante japonês. No entanto, esse ajustamento é feito, sobretudo, para que o imigrante japonês possa trabalhar, o que nos faz voltar para o regime de programação.

Entendemos que há um preconceito linguístico explícito ao se reforçar a imagem do imigrante japonês que "estropia" a língua portuguesa ou, no melhor dos casos, que "arranha" o português. Há também um potencial medo ou ressentimento gerados pela competência do imigrante japonês no trabalho, pois, ao mesmo tempo em que a reportagem constrói a imagem positiva do trabalhador japonês, se deixa implícito que o trabalhador brasileiro não possui a mesma competência para o trabalho.

A reportagem incentiva o governo brasileiro a aumentar a entrada de novos imigrantes japoneses. Duas são as características principais usadas para respaldar esse incentivo: o fato de serem ótimos trabalhadores e por já estarem visivelmente integrados à sociedade brasileira.

O tema da integração, também muito frequente nos discursos que tratam da imigração, está presente em sua realização final: a naturalização. Veremos a seguir como a naturalização e os imigrantes naturalizados são valorizados na próxima reportagem.

\subsection{A defesa da naturalização: benefícios para o Brasil}

\section{Introdução}

Pouco mais de 20 anos depois do final da Segunda Guerra Mundial, a imigração continua a ser uma realidade no Brasil, seja com a entrada de novos imigrantes, seja com a presença maciça deles no país. Assim, a entrada e a presença dos imigrantes continua a suscitar debates como a tratada pela 
reportagem a ser analisada: a integração dos imigrantes. Mas, diferentemente de décadas passadas, em que se discutia a integração em termos de assimilação, esse debate é realizado em outra perspectiva.

A revista Realidade publicou, em 1966, a reportagem intitulada "Vale a pena ser brasileiro?". Apesar de defender a naturalização, a reportagem é, como veremos, uma crítica ao modo como ela é realizada naquele momento no Brasil. O repórter apresenta elementos para considerar o processo de naturalização uma opção desvantajosa para o imigrante que decidiu fixar residência no país. Boa parte dessa opinião decorre da percepção de que a lei de naturalização ainda se baseava, segundo a reportagem, em desconfianças a respeito da "lealdade" do imigrante em relação ao Brasil.

A reportagem vai apresentar elementos para o incentivo à naturalização dos imigrantes, por entender que essa forma de integração é importante para o país. Além do mais, a reportagem mostra a naturalização sem qualquer tipo de discriminação quanto à origem do imigrante, apesar de realizar uma distinção linguística no momento em que dá a palavra aos imigrantes naturalizados.

Para embasar sua crítica à naturalização, a reportagem recorre a exemplos, comparações e citações de imigrantes e especialistas para mostrar como é preciso uma ampla revisão das leis referentes à naturalização. Essa mudança na lei é necessária para oferecer ao imigrante uma gama completa de direitos e de igualdade de condições em relação a qualquer outro cidadão brasileiro nascido no país. Segundo a reportagem, essa mudança é claramente benéfica para o Brasil porque a imagem do imigrante naturalizado é construída como a de um cidadão mais preocupado em ajudar o país do que o brasileiro nato.

Além disso, a reportagem mostra como muitos imigrantes naturalizados contribuem em diferentes áreas (econômica, esportiva e cultural) para 0 desenvolvimento do Brasil. A vida desses imigrantes, tomada como um exemplo, serve também para mostrar que o país ainda precisa perceber que está perdendo a oportunidade de se desenvolver ainda mais no campo econômico por não mostrar interesse e reconhecimento aos que, a despeito das dificuldades em se tornar brasileiro, ajudam o país a crescer e a melhorar.

Iniciaremos nossa análise apontando os principais traços da crítica à naturalização e os recursos utilizados pela reportagem para convencer seu 
leitor de que o país precisa rever suas leis para facilitar a naturalização do imigrante que já decidiu permanecer no país. Em seguida, veremos qual a opinião dos imigrantes que decidiram não solicitar a naturalização. Examinaremos, ainda, quais os prejuízos ao país por manter o modo de naturalização daquele tempo, sob o ponto de vista da reportagem. Por fim, observaremos como a reportagem constrói a imagem do imigrante naturalizado no país, momento em que aparece um traço de preconceito linguístico quando é mencionado o imigrante de origem japonesa.

\section{Críticas à política de naturalização no Brasil}

A reportagem, no começo, procura desfazer a ideia de distinguir brasileiros de imigrantes naturalizados com a apresentação da formação histórica da sociedade brasileira. Mesmo com traços bastante generalizantes, esse começo é importante para se compreender a imagem da sociedade brasileira construída pelo discurso. Além do mais, a reportagem aponta no mesmo trecho o fator responsável pelo pequeno número de imigrantes naturalizados até aquele momento: a Constituição de 1946.

No princípio eram os índios. Depois vieram os portugueses e a nação brasileira começou a se esboçar. O quadro enriqueceu-se com a chegada dos africanos e ganhou a tonalidade definitiva quando, vindos de todas as partes do mundo, milhões de imigrantes fixaram-se no novo país. Todos, num dado momento, tornaram-se brasileiros, com a lei - na grande naturalização da Constituição Republicana de $1891^{148}$ - ou sem ela, pela integração pura e simples. Com o tempo, entretanto, novas leis começaram a diferenciar os brasileiros nascidos no país e os que resolviam se naturalizar. Finalmente, a constituição de 1946, influenciadas pelas ditaduras racistas da Europa e pelo surto de imigração provocado pela guerra, criou para o imigrante que se dispusesse a requerer a cidadania brasileira embaraços e discriminações. Com tudo isso, dos 3.247.893 imigrantes que chegaram ao país em 1900 a 1960, apenas 111.576 se naturalizaram. Isto é, pouco mais de $3 \%$ do total (Ribeiro, 1966: 51).

A formação da sociedade brasileira é construída, pelo trecho acima, como uma progressão que parte da homogeneidade e se transforma em heterogeneidade. Nessa progressão, vemos que a nação brasileira, a partir da presença dos índios, era homogênea (ao menos da forma como a reportagem

${ }^{148} \mathrm{O}$ trecho acima se refere à Grande Naturalização instituída pelo Decreto 58-A (de 1889) e depois retomada pela Constituição de 1891. Em linhas gerais, ambas as leis afirmavam que todo estrangeiro residente no Brasil até a data de 15 de novembro de 1889 se tornaria cidadão brasileiro, salvo os casos de expressa declaração em manter sua nacionalidade de origem (Dal Ri, 2010: 18-19). 
a apresenta). Em seguida, essa homogeneidade começa a se desfazer com a chegada dos portugueses. A constituição heterogênea da sociedade brasileira passa a predominar com os africanos e se torna completa com a vinda dos imigrantes. Dessa forma, o trecho acima serve para construir a imagem da sociedade brasileira (composta por indivíduos vindos de diferentes regiões do planeta) e para mostrar que não é possível continuar a considerar o imigrante naturalizado como um meio-cidadão, pois praticamente todos os brasileiros têm origem em outras regiões do planeta. Evidentemente, a formação da sociedade, descrita sem a menção de conflitos e de extermínios (sobretudo dos índios e dos africanos), serve para realçar e valorizar a diferença como um valor positivo da sociedade nacional.

Além disso, a reportagem mostra, sem citar qualquer fonte, que a lei de naturalização daquele momento se baseia nas Constituições dos regimes totalitários em vigência na Segunda Guerra Mundial. Dessa forma, o imigrante é visto com reservas e desconfianças pelo Estado brasileiro e isso criou, como vimos em outro capítulo, discriminações e dificuldades para o imigrante que desejava tornar-se brasileiro.

A reportagem mostra, em seguida, quais as dificuldades encontradas pelo imigrante para se naturalizar no Brasil. Inicialmente, o texto afirma que a naturalização possui uma série de restrições em torno dos papeis temáticos que o naturalizado pode ter, como podemos observar abaixo:

\begin{abstract}
Ao se naturalizar brasileiro - através de um processo maçante, caro e que demora um ano na melhor das hipóteses - o imigrante torna-se, entre nós, um cidadão de segunda classe. Pesam, sobre ele, quase meia centena de impedimentos, desde ser professor primário até casar-se com funcionário do Itamarati, desde ser aeromoça até vender bilhetes de loteria. Diferentemente da legislação de outros países, onde a naturalização é automática ou pelo menos incentivada e facilitada, no Brasil ela é dificultada e dispendiosa (Ribeiro, 1966: 51).
\end{abstract}

Ao mesmo tempo, o trecho acima faz uma comparação com outros países no que se refere ao tema da naturalização do imigrante. Podemos adiantar que, além dos impedimentos, há uma série de obstáculos e sanções pelos quais o imigrante deve passar até conseguir seu certificado de naturalização, como pudemos apresentar no capítulo 4 desta tese. $O$ imigrante naturalizado tem, inicialmente, um difícil percurso burocrático a percorrer, com 
antissujeitos presentes, para ser sancionado positivamente. Mesmo com essa sanção positiva, sua existência como cidadão brasileiro é cerceada por algumas proibições, como vimos acima.

O texto apresenta uma definição não jurídica da naturalização. Em certa medida, a reportagem realiza uma moralização (em termos semióticos) que tenta causar certa comoção por meio de uma dramatização de todo o processo de naturalização.

\begin{abstract}
Ser brasileiro por naturalização é uma expressão de vontade, um ato de coragem. Para se renegar a terra onde se nasceu e escolher uma outra por pátria, é preciso muito amor, muita decisão, muita crença no futuro da pátria nova. No entanto, no Brasil, tamanha declaração de amor é considerada, ao contrário da maioria dos países, uma quase intromissão. O cidadão que nega a sua pátria para ser brasileiro passa a ser tratado pela lei como uma pessoa permanentemente sob suspeita (Ribeiro, 1966: 52-53).
\end{abstract}

Assim, a naturalização é construída pela reportagem como um /quererser/ brasileiro por parte do imigrante. Mais do que isso, é uma "prova de coragem", ou seja, um /querer-ser/ intenso que leva o imigrante a renunciar a sua antiga nacionalidade (seu outro papel temático). A coragem se refere à necessidade de ultrapassar todos os obstáculos burocráticos para conquistar a nova nacionalidade e também à dificuldade de mudar de nacionalidade e renegar seu país de origem. Em outras palavras, a naturalização é um ato de decisão forte (ou tônica), por acreditar que será melhor para ele. Por isso, segundo a reportagem, o imigrante disposto a se naturalizar deve ter "muito amor, muita decisão, muita crença no futuro da pátria nova". Em outras palavras, esse imigrante precisa estar revestido da modalidade de um /crerquerer-ser/ para realizar sua transformação de nacionalidade.

Contudo, como já vimos, é da opinião da reportagem que o Brasil continua a tratar o imigrante naturalizado como um sujeito "permanentemente sob suspeita". Em outras palavras, a sanção aplicada pelo Estado brasileiro sobre o /ser/ e o /fazer/ do imigrante naturalizado não pode ser compreendida da mesma forma que a sanção feita sobre um brasileiro. Este, enquanto cidadão nato, possui a plenitude (ao menos idealmente) de direitos e deveres previstos em lei, já aquele detém apenas parte desses direitos e deveres, sendo previsto, como veremos abaixo, uma série de restrições de /fazeres/ associados ao imigrante naturalizado. Em outras palavras, o cidadão brasileiro 
nato possui todos os direitos e deveres previstos em lei, enquanto o imigrante naturalizado apresenta uma relação parcial com os mesmos direitos e deveres e, por isso, é um cidadão "pela metade".

Uma prova da não conjunção do imigrante naturalizado com todos os direitos e deveres de um cidadão nacional pode ser vista abaixo. As restrições impostas aos imigrantes naturalizados no Brasil são, assim, apresentadas de forma resumida pela reportagem:

No Brasil, segundo a Constituição, o naturalizado tem 'todos os direitos do brasileiro nato'. Menos 46 coisas, desde ser presidente da República - e esta parece ser uma restrição com a qual todos estão de acordo - até ser prático de balsa no rio Tocantins. Também não pode pregar a Bíblia - ou prestar qualquer tipo de assistência religiosa - em cadeias, hospitais, quartéis. Nem ser proprietário de navios, mesmo para navegar em rios ou lagos. Em meio às várias proibições, há uma que pode encerrar curiosa interpretação: 'dirigir com autonomia empresas de indústria ou comércio numa faixa de $150 \mathrm{~km}$ da fronteira do país'. Se se considerar a costa marítima como fronteira, quase todo o parque industrial de São Paulo - que está a menos de $50 \mathrm{~km}$ do oceano estaria fora da lei, já que ao parte das empresas paulistas tem brasileiros naturalizados em sua direção (Ribeiro, 1966: 55).

As restrições às quais o imigrante naturalizado está submetido são detalhas ao final da reportagem ${ }^{149}$. Basicamente, as restrições se referem à sete temas ou papéis temáticos: o político, o da justiça, o religioso, o de proprietário, o burocrático, o intelectual e o de transporte.

No campo do tema político, o imigrante naturalizado não pode ser, entre outras funções, Presidente da República, senador, ministro de Estado ou Governador. No tema da justiça, ele não pode ocupar o cargo de juiz (em diferentes tipos de tribunal) ou Procurador Geral da República. No campo religioso, ele não pode prestar auxílio religioso nas Forças Armadas, como vimos no trecho acima.

O imigrante naturalizado não pode ser também proprietário ou sócio em empresas de navegação, de comunicação, de mineração ou mesmo ser diretor de empresas estatais. Na esfera burocrática, o naturalizado não pode fazer parte de diversos Conselhos Federais (como o do Trabalho, do Petróleo, de Minas e Metalurgia ou Rodoviário).

\footnotetext{
${ }^{149}$ Como a reportagem não cita as leis em que se encontram as proibições, optamos por não transcrever as listas de proibições na análise.
} 
Em relação ao campo intelectual, o imigrante naturalizado não pode ser mentor intelectual de empresas de comunicação nem ser professor do ensino primário (atualmente, fundamental) ou ainda trabalhar em escolas rurais. Por fim, no campo do transporte, o naturalizado não pode participar de navios fluviais ou marítimos em maior número do que de nacionais, trabalhar em aeronaves nacionais, trabalhar em portos ou mesmo representante de empresas de navegação nacionais.

As restrições são apontadas pela reportagem como um fator de afastamento dos imigrantes que poderiam se naturalizar. Veremos abaixo como os próprios imigrantes justificam sua opção por não se naturalizar e, assim, se tornar um cidadão brasileiro.

\section{A política de naturalização do ponto de vista dos imigrantes e dos especialistas}

Por conta das dificuldades para se naturalizar e das proibições a algumas atividades, o imigrante fica em uma espécie de encruzilhada: continuar imigrante ou transformar-se em um cidadão brasileiro de segunda classe? Segundo o texto, a primeira opção é a escolhida pela maior parte dos imigrantes. Para explicar essa situação, a reportagem exemplifica com a citação do discurso de um imigrante:

- Como estrangeiro, munido de carteira modelo 19 , toco normalmente minha vida. Continuo sendo cidadão de primeira classe de um grande país, com o qual não tenho hoje ligação alguma, mas que também não me aborrece. Em qualquer emergência, tenho o Consulado à disposição, para falar em meu favor. O Brasil não criou, em nenhum momento, qualquer incentivo, mesmo psicológico, nem manifestou o menor interesse em que eu me naturalize. Não peço a cidadania brasileira porque sei que, com ela, vou me tornar um homem com direitos limitados, um semicasado, um meio cidadão. Então nem duvido: continuo italiano (Mariani apud Ribeiro, 1966: 51) ${ }^{150}$.

O relato acima mostra as duas opções para o imigrante: permanecer com sua nacionalidade de origem ou se tornar um brasileiro. Está mais do que claro que para esse imigrante a primeira opção é a mais vantajosa. Dentre as vantagens, ele lista as seguintes: ser "cidadão de primeira classe", ou seja,

\footnotetext{
${ }^{150}$ Carteira 19 é o documento de identificação do registro do estrangeiro no Brasil.
} 
continuar sendo um cidadão pleno em termos de direitos (seja como imigrante, seja como cidadão italiano); ausência de aborrecimentos, ou seja, de tudo o que pode incomodar ou atrapalhar sua existência e sua vida cotidiana; saber que tem uma instância burocrática (o Consulado) que pode socorrê-lo em qualquer momento de "perigo", ou seja, o imigrante continua a ter um destinador em que confia. Além disso, esse mesmo imigrante mostra que faltam incentivos (materiais ou psicológicos) e interesse do Estado brasileiro, além da já citada limitação de direitos. Dessa forma, a fala do imigrante mostra que o Estado não se mostra disposto a manipular (por sedução) o imigrante a se naturalizar. Em outras palavras, o Estado brasileiro não apresenta qualquer interesse em propor um novo contrato para transformar a nacionalidade desse imigrante.

O imigrante mencionado vê vantagens em permanecer com o seu duplo papel temático: o de imigrante no Brasil e o de cidadão italiano, pois assim ele pode manter intactos seus papéis temáticos (italiano e imigrante) no país. Tornar-se um naturalizado não dá a ele a totalidade de traços que definem o cidadão brasileiro e por essa razão ele afirma que seria um "meio cidadão" se se naturalizasse. Do ponto de vista desse imigrante, a manutenção de sua condição de estrangeiro (e de sua cidadania italiana) é interpretada como uma "vantagem", em oposição à desvantagem de se tornar naturalizado.

A oposição "vantagem vs. desvantagem" em relação a qual nacionalidade possuir aparece em outro parágrafo da reportagem, sob o ponto de vista de outro imigrante:

\footnotetext{
A maioria dos italianos e portugueses - que são as duas maiores correntes de imigração no Brasil - não se naturaliza 'porque não é necessário, e também porque a naturalização não traz vantagem nenhuma'. Um motorista de táxi, espanhol, disse que a naturalização traz 'uma desvantagem e um aborrecimento, e só'. A desvantagem é perder a proteção do Consulado; o aborrecimento, ter de votar (Ribeiro, 1966: 51)
}

Resumidamente, a vantagem, enquanto uma categoria avaliativa por parte do imigrante, é apresentada no trecho anterior da mesma forma que encontrada no fragmento acima: o auxílio do Consulado. Já a desvantagem está ligada à modalidade do /dever/, cujo tema visto no trecho acima é o de ser 
obrigado a votar. Assim, a naturalização não apresenta nenhum benefício a mais em relação à situação, já considerada vantajosa, do imigrante no país.

Como a reportagem cita, a percepção geral das vantagens e desvantagens em relação à cidadania do imigrante faz com que o Brasil seja o país, naquele momento, a contar com o maior número de imigrantes no mundo (já que em outros países, como será visto abaixo, a naturalização é um processo incentivado e que apresenta uma série de benefícios ao imigrante). A partir desse fato, a reportagem começa a discutir se essa situação (grande número de imigrantes não naturalizados) é boa ou ruim para o país.

Prosseguindo com a crítica a respeito da situação dos naturalizados no Brasil, a reportagem apresenta a história e as declarações de mais um imigrante naturalizado, como vemos no trecho abaixo:

\begin{abstract}
O sr. Arnoldo Felmanas nasceu na Lituânia, mas é brasileiro naturalizado. Mais, é cidadão honorário de São Paulo, já foi condecorado pelo governo brasileiro e é, também, delegado regional da ONU entre nós. Há vários anos o sr. Felmanas dirige a Liga Pró Direitos dos Brasileiros Naturalizados, e nessa condição é que ele afirma:

- Nenhum país, dos que eu conheço a legislação, é tão extremado na restrição aos direitos dos nacionais por escolha como este nosso adorado Brasil.

O sr. Felmanas diz que a ONU já está organizando a comemoração do $20^{\circ}$. Aniversário da Declaração dos Direitos Universais do Homem, que ocorre em 1968. O Brasil, como um dos signatários do documento, vai ter, agora, que confirma-lo, no Congresso. E a declaração é límpida quando fala que 'todo homem tem direito a uma cidadania' isenta de preconceitos e plena de direitos. Os naturalizados - diz o sr. Felmanas - dariam muito mais de si ao Brasil se se sentissem, também, responsáveis diretos pela imensa tarefa de fazer nosso país uma grande potência. A pátria de cada homem é aquela onde ele vive, trabalha, cria seus filhos, faz planos para o futuro. E o naturalizado, no Brasil, é cercado de restrições, é discriminado. E como aos amigos não se faz restrição, resta que o Brasil trata os naturalizados como inimigos. Não me parece a melhor maneira de somar, de contar pontos para a verdadeira comunhão nacional (Fermanas apud Ribeiro, 1996: 55-57).
\end{abstract}

A figura de Felmanas é construída pela reportagem como a da autoridade a respeito do tema da naturalização, por causa de sua vivência, de seus prêmios e de sua atuação no país. É na opinião desse sujeito que o Brasil possui as restrições mais extremadas aos direitos dos cidadãos naturalizados. Além do mais, ele mostra uma contradição entre a legislação imigratória brasileira (ao menos no que tange aos direitos dos naturalizados) e a Declaração dos Direitos Universais do Homem, sendo o Brasil um dos primeiros signatários. 
Em outra opinião, Felmanas diz que os naturalizados poderiam contribuir muito mais ao país se percebessem que possuem os mesmos direitos de um brasileiro nato e fossem tratados como um cidadão brasileiro ("dariam muito mais de si"). Há, aqui, a opinião de que o sentimento de pertencer a um país não pode ser entendido apenas de forma burocrática, mas sim de forma passional, na relação entre o sujeito (seja ele nascido ou não no país).

Além das críticas de imigrantes naturalizados, a reportagem apresenta algumas opiniões de "especialistas" para mostrar que o país precisa rever o processo de naturalização e as limitações que ele impõe aos imigrantes:

- Não é - responde o professor Canuto Mendes de Almeida, ex-representante
do Brasil na ONU e antigo procurador-geral da República - porque há
manifesto inconveniente político para o país, ao abrigar número tão grande de
estrangeiros que não se naturalizam. Isso pode, até mesmo, ser índice da
germinação de propósitos de instalação de minorias não integradas e
predispostas à disputa eventual de pretensos direitos capazes de comprometer
a unidade nacional. A situação tem de mudar, e para isso os caminhos são
claros: não só atribuir aos brasileiros naturalizados direitos iguais ao do
brasileiro nato (com as exceções já consagradas internacionalmente) como
criar incentivos à naturalização em massa. Impondo, ao mesmo tempo,
restrições e sanções aos estrangeiros que, vivendo aqui plenamente, se negam
sistematicamente a optar pela cidadania brasileira (Almeida apud Ribeiro,
1966: 51).

O grande problema apontado na fala de Canuto Mendes de Almeida é um tema recorrente nos discursos sobre a imigração: o da formação dos chamados "quistos étnicos". Obviamente, o tema não é mencionado diretamente, mas a ideia de que possa haver a possibilidade de surgirem o que o trecho acima chama de "minorias não integradas e predispostas à disputa eventual de pretensos direitos" pode ameaçar a existência de outro tema bastante citado também nos discursos sobre a imigração: a da unidade nacional. Isso ocorre porque a falta de integração pode levar, como foi dito, a disputa de um único objeto-valor por diferentes sujeitos (imigrantes e brasileiros). Dessa forma, na opinião do especialista, mais preocupado com a unidade nacional do país, a naturalização é uma forma de se eliminar a ameaça de desintegração nacional por parte de imigrantes não naturalizados.

Mas o discurso do especialista vai um pouco além no que se refere à naturalização. Ele também critica a desigualdade de direitos à qual os naturalizados são submetidos em comparação aos brasileiros natos. Por isso, 
para se evitar a ameaça à unidade nacional, é preciso naturalizar os imigrantes. E para naturalizá-los, é preciso também rever a lei para coloca-los no mesmo nível de igualdade de direitos e de deveres de um cidadão brasileiro nato. Dessa forma, é preciso tornar o contrato de nacionalidade, já tratado no Capítulo 4, mais sedutor para o imigrante que está no país. Além do mais, o especialista apresenta também a proposta de punir com restrições os imigrantes que se fixaram no país, mas não querem se naturalizar.

A reportagem também cita a fala de ex-deputado que propôs uma revisão no processo de naturalização. Dessa forma, a reportagem reúne outras vozes que concordam com as críticas feitas até aqui à naturalização realizada no país:

- Que naturalização é essa que faz perder a pátria de nascimento ou de sangue e não dá uma pátria nova àquele que satisfaz todos os requisitos de nossa lei? Que naturalização é essa que apenas cria meio-cidadão, humilhando-o com uma desconfiança injusta que desnatura a própria razão do instituto? O naturalizado, no Brasil, com seu atestado de cidadão brasileiro, ganha apenas a ilusão de que é brasileiro. Teve razão Fernando Carneiro quando disse que a legislação sobre naturalizados, entre nós, é a menos liberal de toda América (Cabral apud Ribeiro, 1966: 52).

A naturalização no Brasil cria a categoria de "meio-cidadão", ou seja, de um cidadão que apenas aparentemente é brasileiro, mas na realidade é apenas um naturalizado que, por sua condição, possui uma série de restrições de direitos ao mesmo tempo em que faz esse imigrante perder completamente sua cidadania anterior. Há, assim, o envolvimento das categorias do /ser/ e do /parecer/: de um lado, ele parece ser um brasileiro completo, mas na realidade é apenas um brasileiro parcial.

Outra característica que chama a atenção, na opinião acima, está na questão do país que é oferecido ao imigrante naturalizado. De um lado, o naturalizado deixa completamente a cidadania do seu país de origem, no qual tinha plenos direitos, para receber uma cidadania permeada de restrições e muito distante da igualdade de direitos em relação aos cidadãos natos. Além disso, o trecho acima, em certa medida, moraliza (em termos passionais) a lei de naturalização, pois afirma que a lei humilha o imigrante por se basear em uma "desconfiança injusta". Assim, o imigrante naturalizado é juridicamente 
rebaixado por estar sempre sob desconfiança por parte do governo brasileiro e por não possuir os mesmos direitos de um cidadão brasileiro nato.

Mais uma crítica sobre a naturalização pode ser observada no trecho abaixo. Trata-se de uma opinião favorável à naturalização que ressalta, mais uma vez, o traço de "vontade" por parte do imigrante, ou seja, de seu /quererser/. Segundo a opinião abaixo transcrita, essa vontade do imigrante em se tornar brasileiro o tornaria até mais cidadão do que o brasileiro nato:

\begin{abstract}
Uma das tônicas dos países absorvedores de imigrantes tem sido a propaganda da naturalização. Porque ela acelera a incorporação do imigrante em sua nova pátria, cortando os elos com o país de origem. A naturalização envolve incômodos e despesas, e dela são afastados os levianos e os hesitantes, os indolentes e os tímidos. Há o propósito deliberado de adquirir a nova nacionalidade, daí porque até se diz que o naturalizado é mais cioso de seu país de adoção do que o nacional, de seu país natal, porque enquanto a nacionalidade daquele resultou de uma escolha, a deste derivou do acaso (Rodrigues apud Ribeiro, 1966: 53).
\end{abstract}

A naturalização acelera o processo de integração do imigrante à sociedade nacional. Podemos observar que o imigrante naturalizado é mais preocupado ("cioso") com o país que ele adota, ao menos em relação aos demais cidadãos do mesmo país. Em outras palavras, o imigrante naturalizado pode ser até mesmo mais cidadão do que o brasileiro nato. Além disso, conforme a reportagem, a naturalização, pelas características de etapa que ela possui (além de seus custos), realiza a triagem entre os bons imigrantes e os maus imigrantes (levianos, hesitantes, indolentes e tímidos). Dessa forma, o imigrante naturalizado pode ser considerado o oposto do mau imigrante: sensato, decidido, ativo e ousado.

Todas essas críticas são baseadas, por um lado, pela experiência vivida pelos imigrantes no país; de outro, por brasileiros que observam as limitações da lei nacional. Para fundamentar todas essas críticas, a reportagem apresenta também uma rápida comparação com a situação dos imigrantes naturalizados em outros países, foco da próxima seção de nossa análise.

\title{
Comparação com a política de naturalização de outros países
}

A reportagem não se limita à apresentação de críticas de imigrantes ou de especialistas à naturalização. Ela apresenta também uma rápida 
comparação com o processo de naturalização em outros países. A comparação serve, assim, para mostrar como a lei brasileira é muito mais limitadora e burocrática do que a de outros países. Vemos isso no trecho abaixo, ressaltando algumas características do processo de naturalização encontradas em países muito diferentes:

\begin{abstract}
Os vários países de imigração no mundo reservam um tratamento especial aos estrangeiros que se decidem pela cidadania do país que os acolhe. Em nenhum deles há tantas restrições como no Brasil. Na União Soviética, por exemplo, nem existe o título de cidadão naturalizado. Qualquer pessoa que escolha a cidadania soviética requer ao Praesidium do Soviete Supremo essa condição. Sendo aceito, passa a ser cidadão soviético sem nenhuma restrição. Pode até vir a ser membro do próprio Soviete Supremo. Nos Estados Unidos onde a naturalização é bastante facilitada e seu processamento começa logo na chegada do imigrante ao país - o naturalizado só não pode ser presidente da República.

Nem ocupar cargos - como o de presidente do Congresso, por exemplo cujos titulares são substitutos eventuais do chefe da nação. O resto pode; La Guardia, considerado por muitos o maior prefeito de Nova lorque, nasceu na Itália. Felix Frankfurter, juiz da Corte Suprema, nasceu na Alemanha; Antony Calabreza, outro italiano, foi ministro da Educação de Kennedy; vários senadores e muitos deputados nasceram em outras nações.

No Canadá, o naturalizado tem todos os direitos do cidadão nato. Na França e na Bélgica há uma escala de tempo: cinco anos após o decreto de naturalização, o novo cidadão pode votar; dez anos depois, pode votar e ser votado e, então assumir qualquer função pública. Na Argentina, o prazo para requerer a cidadania é de dois anos de residência no país; com cinco anos a naturalização é automática, com amplos direitos civis e políticos, menos estes: ser presidente da República ou exercer cargos executivos nas Províncias, ser senador ou membro da Corte Suprema. A lei Argentina tem um detalhe curioso: a naturalização envolve também o nome e o sobrenome, que tem de ser traduzidos para o castelhano (Ribeiro, 1966: 53-55).
\end{abstract}

O traço em comum de todos os países mencionados é que nenhum deles possui tantas restrições como o Brasil ${ }^{151}$. O trecho acima vai justamente mostrar como esses países dão certas facilidades para os imigrantes que desejam se naturalizar.

Os exemplos talvez mais radicais estejam na antiga União Soviética e no Canadá. Nesses países, segundo a reportagem, não existe nem mesmo a categoria de "cidadão naturalizado". Todo imigrante naturalizado é considerado cidadão soviético ou canadense, com todos os direitos e deveres previstos em lei. Nos EUA, a naturalização é completamente facilitada e o único impedimento se refere à impossibilidade de se candidatar à presidência do país

\footnotetext{
${ }^{151}$ Obviamente, essas leis se referem ao momento histórico em que a reportagem foi escrita. Desde então, o mundo mudou e acreditamos que a lei de naturalização de ao menos alguns países deve ter acompanhado essas mudanças.
} 
ou a um cargo eletivo que pode, eventualmente, conduzir ao cargo político mais alto da nação norte-americana. A reportagem cita, como exemplo, o caso de prefeitos, juízes, ministros de governo, deputados e senadores que não nasceram nos EUA. A facilidade de se naturalizar significa, nesses casos, um menor número de obstáculos e menos sanções para interpretar a competência do naturalizando.

Na França e na Bélgica, há uma escala progressiva de aquisição de direitos políticos por parte do naturalizando. Assim, depois de 5 anos, o naturalizado pode votar. Após 10 anos, pode votar e ser votado. Na Argentina, o prazo mínimo para se pedir a naturalização é de 2 anos ${ }^{152}$. Depois de 5 anos, a naturalização é automática. Ela possui algumas restrições a mais do que nos demais países (o naturalizado não pode ser presidente ou governador, senador ou membro da Corte Suprema do país). Além do mais, segundo a reportagem, a naturalização envolve também a mudança, ou melhor, a "castelhanização" do nome do imigrante a ser naturalizado.

Em outras palavras, os países citados no trecho acima não apresentam tantos impedimentos para o imigrante naturalizado. Dessa forma, o naturalizado é considerado, nesses países, um cidadão pleno de direitos, muito mais próximo a um cidadão nato ${ }^{153}$.

\section{A naturalização como prejuízo para o país}

Nesta seção, veremos alguns exemplos de como a restrição imposta pela lei está prejudicando o país, que não pode utilizar a capacidade de imigrantes naturalizados em diversas situações. Os exemplos se referem, principalmente, a casos de naturalizados que poderiam atuar na política brasileira, mas foram impedidos por causa da lei.

O primeiro exemplo citado pela reportagem está em um fato ocorrido no Rio Grande do Sul. Um político, muito popular, foi eleito deputado estadual e,

${ }^{152}$ Como vimos no Capítulo 4, o tempo mínimo para solicitar a naturalização na Argentina permanece o mesmo.

${ }^{153}$ A reportagem reforça a ideia de que os naturalizados possuem praticamente todos os direitos nos países citados, no entanto, não deixa claro se o processo de aquisição da naturalização é igualmente facilitado para os estrangeiros que desejam mudar de nacionalidade. Além disso, muitos desses países já mudaram suas respectivas legislações para obtenção da naturalização, principalmente após o surgimento da globalização o aumento do fluxo imigratório em direção aos países desenvolvidos, que atualmente consideram a presença de imigrantes "incômoda" e mesmo um "problema". 
logo em seguida, assumiu a presidência da Assembleia Legislativa gaúcha. Quando houve uma oportunidade para assumir o governo do estado, pois o governador iria se licenciar, ele foi impedido por não ser brasileiro de nascença, mas sim naturalizado:

\begin{abstract}
Um brasileiro naturalizado com jeito para política pode ser vereador, deputado estadual e só. As vezes, com resultados pitorescos. João Caruso era um líder natural, desde menino. Considerado um nacionalista autêntico, gaúcho perfeito, candidatou-se a deputado estadual e, eleito, viu-se logo na presidência da Assembleia Legislativa do Rio Grande do Sul

No meio do mandato de Caruso, o governador precisou viajar para o exterior e pediu uma licença de seis meses. Como o Estado não tinha o cargo de vicegovernador, o seu sucesso natural era o presidente da Assembleia. O povo gostou muito, chegaram manifestações de "regozijo e esperança", mas a bom estourou logo: João Caruso, gaúcho perfeito, era nascido na Itália, chegou ao Brasil quando ainda era criança de colo, e, por isso, não era brasileiro inteiro. Estava, pois, impedido de governar. O governador, decepcionado, desistiu da viagem (Ribeiro, 1966: 57).
\end{abstract}

Mesmo contando com o reconhecimento da população, o referido político gaúcho não pode assumir o governo do estado. Esse impedimento previsto em lei pode ser entendido como um /não-ser/ (brasileiro completo) que conduz a um /não-poder-fazer/ (não governar o estado), já que esse naturalizado não possui a competência modal exigida pela lei brasileira.

Outro exemplo dessa organização modal pode ser visto abaixo. A diferença é que houve uma adaptação para contornar o impedimento previsto em lei:

No começo do governo Jânio Quadros, em São Paulo, aconteceu quase a mesma coisa. Para a secretaria da saúde, Jânio escolheu um conhecido técnico em medicina social, Habib Carlos. Mas logo veio o aviso: o médico era brasileiro só pela metade.

$\mathrm{O}$ dr. Habib tinha chegado ao Brasil ainda criança e era irmão de um homem muito conhecido na política: Emílio Carlos. Jânio, intrigado com o assunto, decidiu: se não vai ser o Habib, vai ser o irmão mais novo, Fauze Carlos, que nasceu aqui. Hoje, os naturalizados já podem ser secretários de Estado, em razão de mandado de segurança que permitiu firmar jurisprudência sobre o assunto (Ribeiro, 1966: 57).

A reportagem mostra, assim, um claro exemplo de que o próprio Estado brasileiro é prejudicado por causa da legislação sobre naturalização no Brasil. A saída foi, nesse caso, realizar uma adaptação e colocar, no lugar do primeiro postulante, o seu irmão, que era brasileiro. A reportagem deixa a entender que o primeiro postulante ao cargo seria, de fato, quem tomava as decisões na 
secretaria da saúde, sendo seu irmão apenas um representante formal do cargo.

Nesta seção, examinamos como a reportagem mostra o prejuízo do país por causa das restrições da lei que dificultam a naturalização no país. Outra forma de apresentar esse prejuízo ao país será vista abaixo. Trata-se da imagem positiva do imigrante naturalizado.

\title{
A construção da imagem do imigrante naturalizado
}

A reportagem constrói uma imagem positiva dos imigrantes naturalizados. Essa imagem positiva serve para a reportagem apresentar as vantagens de se contar com um maior número de imigrantes naturalizados para o país. O trecho abaixo mostra, de forma generalista, os inúmeros benefícios gerados pela presença desses imigrantes ${ }^{154}$ :

\begin{abstract}
Passa-se o mesmo no Brasil. A frase patriótica - O Brasil espera que cada um cumpra o seu dever - foi dita pelo almirante Barroso, que não era brasileiro nato. Em todos os campos, brasileiros naturalizados se destacam. Nas universidades, a sua participação é fundamental. A indústria e a lavoura têm nos seus grandes pioneiros brasileiros por escolha. Na própria música popular ele está presente, e basta citar Carmem Miranda. Otto Maria Carpeaux é considerado pelos críticos mais rigorosos uma das maiores glórias das letras brasileiras e nasceu na Alemanha. Nas artes plásticas a influência dos naturalizados é notável, e pode ser medida com dois nomes conhecidos no mundo inteiro como representantes da nossa pintura: Lasar Segal e Manabu Mabe. No cinema - com Rui Guerra e Jean Manzon - no teatro - com Henriette Morineau, Ziembinski, Eugênio Kusnet - no esporte - a seleção brasileira de beisebol foi campeã sul-americana jogando só com japoneses - e em todos os campos de afirmação nacional os brasileiros naturalizados atuam com dedicação, por inteiro (Ribeiro, 1966: 58).
\end{abstract}

Todos os imigrantes acima destacados pela reportagem são, em geral, personalidades bastante conhecidas da sociedade brasileira. Mas a reportagem mostra também a história de sucesso de imigrantes naturalizados "comuns", ou seja, pessoas não conhecidas do grande público. Basicamente, são histórias de sucesso que servem para reafirmar a ideia de que naturalizarse pode ser bom para o imigrante e, principalmente, para o país. Examinaremos, em linhas gerais, os traços que norteiam a construção dessas histórias para, no final, refletimos como elas são utilizadas para mostrar que o

${ }^{154}$ É interessante notar que os elogios são todos voltados para o naturalizado, mas em nenhum momento houve um claro elogio ao imigrante que não se naturalizou 
imigrante naturalizado tem sua importância para a sociedade brasileira por conta de seus feitos no dia a dia da sociedade brasileira.

Os perfis apresentados são bem variados. Temos desde um médico que trabalha com índios até o famoso comediante Oscarito, passando por empresários, comerciantes e agricultores reconhecidos por sua competência e pelo sucesso em sua área de atuação.

Podemos, de forma generalista, apontar dois tipos de imigrantes naturalizados na reportagem: os que trabalham ou são proprietários de seus negócios (dono de restaurante, dono de uma empresa de calçados, dono de uma fábrica de máquinas de costura, dono de uma joalheria e dono de um vinheiro). O outro grupo de imigrantes pode ser ligado pelo trabalho liberal, artístico ou esportivo: um médico que trabalha com índios, um técnico de futebol, um comediante e um músico.

No caso do primeiro grupo, o destaque fica para a história de empresários bem sucedidos que, mesmo com dificuldades, conseguiram abrir seus negócios e passaram a empregar muitos brasileiros em suas empresas. No segundo grupo, a ideia central é a de que eles fazem os brasileiros mais felizes de diferentes formas, seja com a diversão seja cuidando da saúde dos índios (como no caso do médico). Dessa forma, a figura do imigrante naturalizado é construída de forma a passar a ideia de que os naturalizados são bem sucedidos e auxiliam o Brasil a crescer economicamente e a ser mais feliz.

Um primeiro traço que atravessa todos os discursos sobre esses imigrantes naturalizados é, justamente, o de sucesso desses sujeitos. Esse sucesso pode ser visto tanto como um reconhecimento de sua atuação em uma determinada área como também uma vida materialmente bem sucedida, fruto do trabalho árduo do imigrante naturalizado no Brasil.

Em 1920, Joaquim Melo da Cunha, português de Penafiel, desembarcou no Rio. Tinha 22 anos e foi ser balconista de uma loja de tecidos. Em 1966, Joaquim Melo da Cunha, brasileiro naturalizado, preside a maior indústria de calçados da Guanabara, a DNB (Do Nosso Brasil). Tem, de contrapeso, 15 lojas e 700 empregos" (Ribeiro, 1966: 53).

Quando Giácomo Franco chegou ao Brasil, em 1939, nosso país importava máquinas de costura. Ele então fundou uma firma importadora, para cuidar disso, e começou a comprar milhares de máquinas no exterior. Mas em 1945, após naturalizar-se brasileiro, mudou completamente seu esquema de trabalho: 
(...)

Montou uma fábrica, e já em 195320 máquinas ficavam prontas. Hoje a Vigorelli do Brasil produz 500 máquinas de costura por dia e, faz cinco anos, vende para outros países boa parte de sua produção" (Ribeiro, 1966: 54).

Hiroshi Saito chegou, há 34 anos, para ser colono na divisão São Paulo Mato Grosso. Casou-se aqui, e tem cinco filhos, todos trabalhando com ele. Após 14 anos de trabalho como meeiro, conseguiu dinheiro para comprar três alqueires de terra em Ibiúna. Plantou hortaliças, tomate, batatas, até apaixonarse pela uva. Hoje é doutor no assunto (Ribeiro, 1966: 55).

Outro traço está na descrição da decisão de se tornar ou se sentir brasileiro, uma vez que alguns desses imigrantes já vieram adultos para o país, enquanto outros chegaram ainda crianças com sua família. De qualquer forma, todos mostram seu sentimento de brasilidade, ou seja, de se considerarem brasileiros como qualquer outro. Alguns desses imigrantes apontam, inclusive, certos traços de "brasilidade" ou mesmo se consideram mais brasileiros do que a "média" nacional.

Em todas essas descrições, aos naturalizados é dada a voz. De um modo geral, essas falas relatam a felicidade de estar definitivamente no Brasil e a falta de desejo de ir embora.

— Eu só vim a saber que não era brasileiro por inteiro - diz Nutels - quando fui tomar posse no Serviço de Proteção aos Índios. E fiquei assustado: meu pai era senhor de engenho e minha mãe morreu de esquistossomose; quer mais brasilidade do que isso? (Nutels apud Ribeiro, 1966: 52).

- Minha maior frustração como brasileiro é não saber dançar o samba. Em compensação, quando estudante, integrei um conjunto criado por Capiba e dei aulas de frevo no Brasil inteiro (Nutels apud Ribeiro, 1966: 52).

- Se o Brasil se envolvesse numa guerra - e que Deus nos livre disso - a minha família estaria toda na linha de frente. Haim é tenente do Exército e Fernando, meu genro, é oficial da Força Pública de São Paulo. E eu, por certo, não os deixaria brigar sozinhos... (Franco apud Ribeiro, 1966: 54).

- Eu sempre me esqueço de que não nasci aqui. O Brasil tem alguma coisa que atrai, que amarra a gente, e eu me sinto brasileiro completamente (Oscarito apud Ribeiro, 1966: 55).

Quando a reportagem trata do representante da imigração japonesa Hiroshi Saito, agricultor -, uma peculiaridade é ressaltada: a forma como ele se expressa. Vejamos o trecho abaixo:

No supermercado, uma senhora compra frutas. Fica encantada quando vê aquelas uvas brancas, imensas, cada uma do tamanho de uma noz. Pensa no preço e pergunta: 
- São uvas do estrangeiro, não?

$O$ vendedor diz que sim. A freguesa ainda vai dizer qualquer coisa, mas um japonês de óculos se intromete:

-Entarandgero non. Uva barasirêro, garantido. Uva chama Itaria mas é parantada aqui, colhida aqui. Uva barasirêro cem por cento (Saito apud Ribeiro, 1966: 55).

Enfim, o imigrante japonês é o único a apresentar tal peculiaridade com o uso da língua portuguesa. Os demais imigrantes, de origens muito distintas (como lituano, italiano, espanhol, etc.), não apresentam essa tentativa de marcação do sotaque que eles podem, eventualmente, carregar (nem mesmo o proprietário do restaurante francês, que já chegou ao Brasil contratado com a função de ser o mâitre de um restaurante no Rio de Janeiro).

Logo depois, o imigrante japonês retoma a sua fala, mas já sem as marcas de seu sotaque, como vemos abaixo:

Saito diz apenas:

- A melhor maneira de se viver e de se produzir, não é em liberdade? Eu escutava a uva e a deixava fazer o que quisesse, procurando entender sua natureza, sem forçá-la (Saito apud Ribeiro, 1966: 55).

Não é possível afirmar categoricamente que há, no exemplo acima, um caso de intolerância ou de preconceito linguísticos, mas fica um destaque linguístico marcado no caso do imigrante japonês, ao se tentar reproduzir o seu sotaque quando vai falar em português, fato não encontrado em outros imigrantes apresentados nessa reportagem.

Vimos, nesta seção, como a imagem do imigrante naturalizado é construída pela reportagem. São, de um modo geral, sujeitos bem sucedidos em sua área de atuação e que apresentam uma forte ligação afetiva com o Brasil. Dessa forma, a reportagem mostra que o país só tem a ganhar com um maior número de imigrantes naturalizados e, para que isso se torne realidade, basta o governo reformar a lei de naturalização para facilitar a integração do imigrante à sociedade nacional.

\section{Conclusões parciais}

Dois aspectos distintos, mas complementares, precisam ser destacados na reportagem: a) a crítica ao processo de naturalização realizado no Brasil; b) 
os benefícios advindos dos imigrantes naturalizados, que auxiliam no desenvolvimento econômico e cultural do país.

Para o primeiro aspecto, a reportagem destaca declarações de imigrantes que não se naturalizaram e de especialistas que criticam diretamente o caráter burocrático e restritivo da naturalização, que não dá ao imigrante todos os direitos de um cidadão nacional por proibi-lo de ocupar determinados cargos ou funções no país. Além disso, a reportagem compara a naturalização brasileira com a de outros países para justificar as suas críticas à lei de naturalização do país. Consequentemente, o Brasil acaba sendo prejudicado por suas leis, pois muitos imigrantes não naturalizados poderiam se sentir bem acolhidos (e cidadãos brasileiros plenos de direitos) e, assim, auxiliar o país em seu desenvolvimento econômico e cultural.

Para comprovar essa perspectiva, a reportagem constrói uma imagem positiva do imigrante naturalizado (segundo aspecto apontado acima). Dessa forma, o imigrante naturalizado é representado como um sujeito bem sucedido e feliz por viver no Brasil. No meio dessa construção da imagem positiva do imigrante naturalizado, vimos que, no caso do imigrante japonês, a reportagem apresenta uma distinção de sua fala, ressaltando o sotaque do japonês que usa a língua portuguesa, fato não encontrado nas falas de outros imigrantes entrevistados pela reportagem. Contrariando o tom mais formal que permeia a reportagem, a fala com sotaque do imigrante japonês retoma a ideia presente na primeira reportagem analisada neste capítulo: a de que ele "arranha" ou "estropia" o idioma nacional.

Uma das declarações apresentadas (a de Canuto Mendes de Almeida) pela reportagem ainda justifica a naturalização como uma forma de se evitar uma possível ameaça à unidade nacional. Inicialmente, essa declaração parece estar em contradição com o restante da reportagem, que elogia a diversidade de imigrantes no país, assim como a constituição da sociedade brasileira (formada também por índios e africanos). Contudo, essa declaração pode ser entendida como de acordo com o restante da reportagem se pensarmos que sua ideia central é a de reforçar a noção de uma unidade nacional e, consequentemente, a de que todos os indivíduos que a compõem são, enfim, brasileiros, sejam natos sejam naturalizados. 


\subsection{Tipologia das interações entre estudantes estrangeiros e brasileiros: da programação ao acidente ${ }^{155}$}

\section{Introdução}

A intolerância e o preconceito não encontram, nos dias atuais, o mesmo espaço para sua expressão e sua realização, como no passado. As restrições, no espaço público, a posturas intolerantes e preconceituosas decorrem de mecanismos sociais e jurídicos que punem quem insiste em tentar fazer o mal ao outro ou possui uma opinião negativa do outro, baseada em um suposto conhecimento que se revela sem fundamento. Isso não significa, contudo, que as formas de exclusão e de rebaixamento da alteridade simplesmente desapareceram. Mesmo com mecanismos que impeçam a sua livre expressão, a intolerância e o preconceito continuam presentes e atuantes contra diferentes formas de alteridade. Basta abrir um jornal para se encontrar relatos de violências explícitas contra homossexuais, negros, nordestinos, moradores de rua, imigrantes e seus filhos entre outros. Por isso, examinar notícias veiculadas nos meios de comunicação de massa é uma maneira de se perceber como a intolerância e o preconceito continuam, lamentavelmente, presentes nas sociedades contemporâneas.

Nesta seção, examinaremos jornais de grande circulação nas capitais brasileira que relatam alguns casos de preconceito e de intolerância, principalmente linguísticos, contra estudantes imigrantes ou de ascendência mais destacada, como os filhos de imigrantes asiáticos ou latino-americanos. As notícias versam, principalmente, sobre o contexto escolar (incluindo o curso preparatório para o vestibular) e as formas de interação entre estudantes brasileiros, de um lado, e estudantes imigrantes, de outro.

Cada parte desta análise utiliza uma reportagem para mostrar algumas formas de preconceito e intolerância contra os estudantes filhos de imigrantes. Além do mais, para cada reportagem, será destacada uma forma de interação, tal como proposto por Landowski em seu trabalho, Les interactions risquées (2006). Assim, iniciaremos a análise com o regime de programação, passando

${ }^{155}$ Parte desta análise será publicada no livro Intolerância e preconceito linguísticos (Barros, org., no prelo). 
em seguida para o regime de manipulação. Depois, examinaremos como a ausência do regime do ajustamento pode produzir um contexto escolar pouco aberto à diferença constitutiva da alteridade. Por fim, examinaremos o regime de acidente e as consequências desse regime na organização modal e no programa narrativo dos imigrantes e de seus filhos.

\section{Programação e estereótipo ${ }^{156}$ : o caso dos estudantes de origem asiática nos cursos preparatórios para o vestibular}

Todos os anos, milhares de alunos saídos do ensino médio passam pela experiência, muitas vezes estressante, de prestar o vestibular para as melhores universidades do país. A forte concorrência e, por vezes, a pressão familiar levam o estudante a uma carga desumana de dedicação aos estudos, uma vez que os cursos mais procurados não têm, obviamente, lugar para todos os interessados.

Muitos candidatos procuram o auxílio dos chamados cursinhos, instituições ou empresas dedicadas a ensinar (ou "reensinar") todas as matérias do ensino médio para quem quer garantir sua vaga no desejado curso. É nesse ambiente do cursinho que o jovem pré-universitário convive com uma rotina estressante e com a possibilidade de frustração. Além do mais, é ainda nesse ambiente que imagens preconcebidas de outros candidatos são formadas, como no caso dos estudantes de origem asiática.

Para analisar a construção da imagem dos estudantes de origem japonesa nos cursinhos, utilizaremos duas reportagens do jornal Folha de $S$. Paulo ("Brincadeira entre alunos é 'preconceito positivo'" e "'Asiáticos' procuram mais a área de exatas na Fuvest", ambas publicadas em 05 de setembro de 2002). As duas reportagens tratam do estereótipo dos descendentes de imigrantes asiáticos no contexto escolar (nesse caso, principalmente na situação de vestibular) e em como esse estereótipo determina a relação com os demais vestibulandos.

\footnotetext{
${ }^{156} \mathrm{O}$ estereótipo pode ser entendido como o produto de um preconceito, por ser um esquema fixo e de caráter redutor. Essa redução decorre de um processo de categorização e de generalização que simplifica as características de uma pessoa ou de um grupo social (Amossy e Herschberg Pierrot, 2007: 26-27). Essa perspectiva, de considerar o estereótipo como o produto de um preconceito, é encontrada principalmente nos estudos de Psicologia Social e Sociologia, mas nada nos impede de tomarmos emprestada essa concepção para os estudos do discurso.
} 
É comum encontrarmos os seguintes ditados nos cursinhos: "enquanto você respira, tem um japonês estudando" ou "mate um japonês para garantir sua vaga na USP". Esses ditados, de tom jocoso e usados em uma chave irônica, decorrem de uma imagem cristalizada dos descendentes de japoneses (e de outros asiáticos) na sociedade brasileira. Essa imagem associa os estudantes "orientais" a uma grande dedicação e disciplina para os estudos, não apenas nessa fase de ingresso em uma universidade, mas em qualquer fase da vida escolar. Podemos ver isso claramente no trecho abaixo, tirado da reportagem: "'Enquanto você está aqui, há um japonês estudando' ou 'morte aos japoneses' são pichações comuns em banheiros de cursinhos prévestibulares" (Folha de S. Paulo, 05/09/2002: Especial 3).

As frases pichadas nos banheiros revelam dois aspectos do estereótipo do estudante de origem asiática. De um lado, a dedicação aos estudos; de outro, a tentativa de eliminação desse estudante por ele ser considerado um competidor mais bem preparado para entrar na universidade. A dedicação ao estudo pode ser mais bem explicada na reportagem, como vemos abaixo:

\begin{abstract}
No imaginário dos vestibulandos, "olhos puxados" costumam ser associados à inteligência e à capacidade de estudo, logo a um melhor desempenho nas provas e à ameaça na disputa por uma vaga na universidade. Os números do último vestibular da Fuvest mostram que, de fato, estudantes de origem asiática tiveram melhor aproveitamento nos exames - a taxa de aprovação dos que se declaram amarelos é de $9,8 \%$ e a de brancos é de $6,7 \%$

A explicação para as boas notas não se deve a nenhuma característica genética dos orientais, mas sim pode estar relacionada, segundo especialistas, à cultura de valorização da educação - o que muitas vezes significa cobrança dos pais e longas horas de estudo.

O pai de Aldo Miike, 20, sempre exigiu o bom desempenho escolar do filho. "Agora, ele não pressiona tanto como antes, mesmo porque já estou acostumado a estudar muito", disse o estudante, que vai tentar uma vaga em relações públicas na USP (Folha de S. Paulo, 05/09/2002: Página especial 1).
\end{abstract}

O trecho acima mostra, ainda, dados da Fuvest (maior vestibular do país) para comprovar a imagem de alunos inteligentes e competentes no momento da seleção para ingresso na maior universidade do país (pois, proporcionalmente, o estudante de origem asiática está em maior número que os demais). Ao mesmo tempo, a reportagem deixa claro que essa competência do estudante de origem asiática não pode ser explicada em termos "raciais", ou seja, como uma predisposição genética que os faria mais inteligentes que os demais estudantes. $O$ fato desses estudantes se destacarem no vestibular 
pode ser explicado pela dedicação aos estudos imposta pela família, como vemos no último parágrafo do trecho acima. Justamente por haver uma manipulação de seus pais (por intimidação e por provocação), o estudante de origem asiática se reveste da modalidade do /dever-saber/ para ter o desempenho esperado pelos seus pais.

Ao contrário do que encontramos na análise dos artigos (capítulo anterior), a reportagem do jornal Folha de $S$. Paulo não menciona a questão racial. Em seu lugar, a reportagem fala em "fator cultural". As características dos estudantes de origem asiática podem ser compreendidas como hábitos ou comportamentos adquiridos no seio familiar, com a diferença de que não se trata mais de um traço inerente ao /ser/ do estudante de origem asiática, mas sim a alguma forma de "estilo de vida" da família desse estudante. Assim, não é possível sustentar que todos os estudantes de origem asiática são todos disciplinados e dedicados, como a própria reportagem procura relativizar:

\begin{abstract}
O fator cultural pode caracterizar a maneira como alguns descendentes de orientais estudam. Segundo o professor Santos, eles costumam valorizar a disciplina, a ordem e a concentração. "Nós [ocidentais], quando estudamos, ouvimos música e nos expomos a outras fontes de dispersão. O oriental concentra-se totalmente no estudo" (Folha de S. Paulo, 05/09/2002: Página especial 3).
\end{abstract}

Dessa forma, o trecho acima constrói dois simulacros distintos: de um lado, o estudante de origem asiática com traços de disciplina, ordem e concentração; de outro, o estudante "ocidental", disperso. Consequentemente, o discurso mostra que as características do estudante asiático são mais valorizadas no momento do estudo, enquanto o estudante "ocidental" apresenta traços mais negativos. É interessante ainda observar como foi colocado pelo narrador, entre chaves, a palavra "ocidentais" para marcar a diferença entre estudantes não asiáticos e os descendentes de imigrantes asiáticos.

A primeira reportagem mostra, como subtítulo, o seguinte enunciado: "Estereótipo não deve levar vestibulando a temer concorrência com 'orientais'". Nesse mesmo enunciado vemos a palavra "orientais" entre aspas. Em certa medida, o enunciador mostra como os estudantes de origem asiática são identificados pelos demais estudantes: a partir do gentílico de seus 
antepassados. Isso, levando-se em conta que esses estudantes "orientais" são, muitas vezes, brasileiros.

O discurso estabelece, assim, outra oposição (falsa, na realidade): os estudantes "brasileiros" e os estudantes "orientais". Vemos, assim, a força com que a imagem dos estudantes de origem asiática é construída a partir dessa diferença de aparência (desvio do estudante branco, ocidental). Consequentemente, a oposição leva à construção do estereótipo do estudante de origem asiática $^{157}$.

Ainda com base no enunciado acima destacado, vemos que a reportagem tem claramente como enunciatário os estudantes "brasileiros", ou seja, de origem não asiática. O texto do jornal procura desconstruir, parcialmente, o estereótipo do estudante de origem asiática como forma de eliminar um possível "temor" dos estudantes em relação aos seus "concorrentes" por um lugar na universidade. A capa do caderno especial, voltado para alunos no período pré-vestibular, apresenta o título, sem aspas, da "ameaça amarela" ${ }^{158}$, retomando, assim, o discurso da ameaça nipônica do Brasil. Esse discurso remete, frequentemente, à ideia de invasão e do Estado dentro do Estado, muitas vezes ligado também à ideia de que os imigrantes japoneses e seus descendentes são um grupo social a parte porque não se integram à sociedade. Dessa forma, a reportagem parece se preocupar em desfazer o estereótipo dos estudantes de origem asiática para tranquilizar o estudante "brasileiro" e não porque o estudante "oriental" pode ser vítima de preconceito.

Uma das explicações para essa preocupação da reportagem está no fato de o estereótipo se refletir na relação entre os estudantes de origem asiática e os demais estudantes, conforme vemos no trecho abaixo:

Os vestibulandos costumam dizer que não passa de brincadeira a ideia de que os estudantes de origem asiática conquistam mais vagas nas melhores universidades. Mas o mito pode causar ainda mais expectativa em quem já

\footnotetext{
${ }^{157}$ Precisamos, contudo, deixar claro que o estereótipo não é uma figura construída somente por essa reportagem. Na verdade, a reportagem "veicula" o estereótipo do estudante de origem asiática encontrado frequentemente nos cursinhos.

158 Antes mesmo do início do processo imigratório japonês para o Brasil, já existiam discursos que associavam os imigrantes japoneses a temas como "perigo amarelo", "formação de quistos étnicos" e "caráter inassimilável do nipônico". O discurso antinipônico teve seu ponto culminante nas primeiras décadas do século XX, quando uma série de trabalhos acadêmicos, artigos de opinião e outros discursos contra os imigrantes japoneses surgiram nos EUA, no Peru e no Brasil (Dezem, 2005: 185-204).
} 
está bastante preocupado com a concorrência no vestibular (Folha de S. Paulo, 05/09/2002: Página especial 3).

Assim, o estudante "brasileiro", que já está preocupado com o seu desempenho no vestibular, pode se preocupar ainda mais diante da imagem de um suposto forte concorrente, representado pelo estudante "oriental". Consequentemente, o estudante "brasileiro", atento ao desempenho do seu antissujeito (porque o estudante "oriental" pode "roubar" sua vaga), passa a duvidar de sua própria competência no vestibular.

Os próprios estudantes "brasileiros" apresentam uma relativização dessa imagem fixa (porque não deve ser "levada a sério", pois não é verdadeira). Tratar-se-ia apenas de uma brincadeira. O enunciador, no entanto, contraria (ao menos parcialmente) essa afirmação dos estudantes "brasileiros" ao dizer que esse estereótipo pode interferir no estado passional dos demais vestibulandos, produzindo ansiedade, quando não temor, nos estudantes mais preocupados em ser aprovado no vestibular.

Dessa forma, existe a possibilidade, nesse espaço de interações sociais constituído pelo cursinho, de estudantes "brasileiros" acreditarem no simulacro do estudante de origem asiática. Esse simulacro é, basicamente, constituído por um /poder-fazer/ e por um /saber-fazer/ superiores a desses estudantes "brasileiros". Evidentemente, esse simulacro existe antes mesmo de qualquer situação de interação entre esses dois tipos de estudante. Por essa razão, o estudante "brasileiro" pode se sentir inferior (/saber-não-ser/) em relação ao estudante de origem asiática, uma vez que essa expectativa pode ser compreendida em termos semióticos como uma forma de construção fortemente positiva da alteridade (o estudante "oriental") ao mesmo tempo em que o estudante "brasileiro" constrói uma imagem negativa de si, baseada em uma inferioridade intelectual ou em uma falta de dedicação aos estudos.

Por ser considerada uma imagem positiva (a da dedicação e a da disciplina aos estudos), a imagem fixa do estudante de origem asiática é considerada muitas vezes um "preconceito positivo":

Essa espécie de preconceito positivo em relação aos orientais, segundo Zélia de Brito Fabre Demartini, professora de educação da Universidade Metodista e da Unicamp, tem origem na chegada dos primeiros imigrantes ao Brasil. "Eles planejavam retornar ao país depois de melhorar seu padrão de vida. A 
educação era uma das formas encontradas por eles para se inserir e ascender na sociedade brasileira da época" (Folha de S. Paulo, 05/09/2002: Página especial 3).

Podemos entender o "preconceito positivo" como, primeiro, um preconceito porque é uma opinião baseada na imagem fixa e generalizada de um grupo social (o de estudantes de origem asiática). Em seguida, o positivo pode ser entendido de duas formas: a) como uma forma socialmente aceita, incentivada ou desejada (mesmo sendo uma imagem fixa e generalizante); b) como uma forma que pode levar o outro, que não se inclui nesse grupo, a tentar "alcança-lo", ou seja, se esforçar para alcançar o mesmo patamar de qualidade do grupo estereotipado. Obviamente, esse "preconceito positivo" está presente nos estudantes "brasileiros" e, como vimos, ele pode ser encarado como mais um incentivo para se dedicar com afinco aos estudos ou pode ser a fonte de temor e de ansiedade para esse mesmo estudante "brasileiro".

Assim, a intolerância linguística, propriamente dita, está relacionada à outra marca desse estereótipo: a de que os descendentes de asiáticos seriam bons alunos na área de ciências exatas por supostamente não dominarem a língua portuguesa de modo considerado apropriado. Essa questão do estereótipo em relação ao uso da língua portuguesa aparece de forma implícita no seguinte exemplo:

Segundo Francisco Hashimoto, professor de psicologia da Unesp de Assis, os imigrantes orientais, ao chegarem ao Brasil, tinham dificuldades com a língua, - que impunha obstáculos ao aprendizado das matérias de humanas. "O cálculo matemático é uma linguagem universal e, por isso, não causa problemas", disse ele, que estudou a imigração japonesa. Isso teria sido mais forte nas primeiras gerações, diminuindo com a vida no Brasil. Outro fator que pode explicar a preferência pelas exatas, segundo Hashimoto, é a personalidade mais introvertida de parte dos orientais, o que os faz preferir, muitas vezes, profissões em que não seja necessário um maior contato com o público (Folha de S. Paulo, 05/09/2002: Página especial 3).

A parte final do trecho acima mostra outra característica dos estudantes "asiáticos": a timidez. Essa pode ser uma possível explicação para a falta de "manejo" com o idioma. Evidentemente, a timidez é um traço encontrado nos estudantes de origem asiática, mas não está presente em todos. Além disso, a 
timidez pode também estar em estudantes de outra origem sem que isso se torne um traço definidor do grupo.

As reportagens mencionadas parecem, então, reduzir a figura dos descendentes de imigrantes asiáticos a apenas duas características principais que definiriam todos os membros desse grupo: a dedicação aos estudos e a dificuldade com o uso da língua portuguesa, esta última responsável pela preferência dos estudantes de origem asiática por disciplinas da área de exatas.

Os textos analisados não se resumem a explicitar os traços que definem o estereótipo do estudante de origem asiática. Como dissemos anteriormente, a reportagem parece estar mais preocupada em desfazer o possível temor do estudante "brasileiro", gerado pela presença do estereótipo. Por isso, a reportagem apresenta algumas propostas para solucionar esse problema:

Antes de se deixar levar pelo preconceito e temer a concorrência, o vestibulando deve aprimorar os estudos e manter a autoconfiança. "Não sou daqueles que acham que os 'japoneses' vão roubar minha vaga. Isso depende da confiança que a pessoa tem em si mesma. Se ela não estuda, imagina que os orientais sejam mais inteligentes", diz Eduardo Abbud, que prestará para medicina (Folha de S. Paulo, 05/09/2002: Página especial 3).

O trecho acima mostra que a ideia de que o estudante de origem asiática é mais dedicado e disciplinado é apenas um preconceito positivo. Em certa medida, o trecho acima mostra que esse preconceito é o responsável pela falta de confiança do estudante "ocidental". Consequentemente, para desfazer esse estereótipo, o primeiro passo é readquirir a confiança em si mesmo para poder "competir" com o estudante de origem asiática no vestibular. O estudante "brasileiro" precisa, assim, estar revestido da modalidade do /crer-saber-fazer/ para ter confiança em si mesmo para participar do vestibular.

Assim, uma das saídas para esse estado passional (de temor) do estudante "brasileiro" é dada pelo trecho abaixo. Ao invés de permanecer se sentindo inferior ao estudante "oriental", o estudante "brasileiro" pode se esforçar para adquirir cada vez mais a modalidade do /saber/ para sair de seu estado passional negativo. 
"Depois de olhar a lista de aprovados e perceber que há muitos nomes orientais, decidi que tinha de estudar mais", disse Douglas Duarte Muniz, 18, que quer estudar engenharia e resolveu se esforçar mais nas aulas, assim como Marcelo Koga, 19, que vai concorrer a uma vaga no mesmo curso (Folha de S. Paulo, 05/09/2002: Página especial 3).

Outra solução para se tentar desfazer esse estereótipo do estudante de origem asiática é apontada pela reportagem. Trata-se de um maior contato com os estudantes com essa característica. Dessa forma, o estudante "brasileiro" pode talvez perceber que o estereótipo nem sempre será encontrado em sua forma "viva" em todos os estudantes de origem asiática. Por meio desse contato e dessa convivência, o estudante não asiático vai perceber que o estereótipo, responsável pelo seu "temor", nem sempre se realiza, ou seja, nem todo estudante de origem asiática é mais inteligente ou mais dedicado aos estudos do que o normal:

Com o passar das gerações, os imigrantes acabaram assimilando hábitos brasileiros e, muitas vezes, a valorização do estudo diminuiu, mas a imagem formada naquela época permaneceu. "A dedicação ao estudo, muito intensa nas primeiras gerações, acabou formando o estereótipo", disse Marcos Ferreira Santos, professor de antropologia da educação da USP. É por isso, segundo ele, que a convivência muitas vezes acaba com a ideia de que o oriental é mais estudioso. "No colegial, eu achava que eles eram mais inteligentes, mas, no cursinho, percebi que somos iguais", disse Everton Santos, 19 (Folha de S. Paulo, 05/09/2002: Página especial 3).

O fragmento acima recorre a uma explicação histórica para confirmar a isotopia temática presente nessa reportagem para mostrar como o estereótipo se formou: o suposto desempenho dos estudantes "orientais" em relação à educação decorre do fato de que a educação dos filhos foi sempre uma preocupação dos imigrantes japoneses. Como vimos no capítulo anterior, Cardoso menciona o estudo como uma forma de ascensão social do nissei (primeira geração de brasileiros filhos de imigrantes japoneses). Contudo, a antropóloga não menciona qualquer traço de dedicação ou disciplina especificamente voltada para os estudos, tampouco um possível melhor desempenho escolar em relação a estudantes "brasileiros". De qualquer forma, o problema do estereótipo, nesse caso, é o de associar os traços já mencionados de dedicação e disciplina aos estudos a todo e qualquer indivíduo identificado como "oriental". Apesar de não ter sido mencionado pela reportagem, precisamos lembrar que o estudante dedicado e disciplinado, 
independente de sua origem, é muitas vezes considerado "tolo" e "ingênuo" pelos demais alunos. Dessa forma, essa outra imagem - a de um estudante ingênuo e tolo - também pode ser associada ao estudante de origem asiática. O estereótipo do estudante de origem asiática não carrega apenas traços positivos. Como vimos, há, na constituição de sua imagem, também elementos que podem ser considerados negativos ou ao menos limitadores na caracterização desse grupo, relacionado à sua competência linguística ${ }^{159}$.

As duas reportagens analisadas tentam ainda minimizar a discriminação contra estudantes de ascendência asiática por meio de justificativas (históricas e psicológicas) para o comportamento e as escolhas desses estudantes. Porém, essas reportagens recuperam marcas históricas do preconceito contra os asiáticos e não vão além da retomada e fixação do estereótipo, sendo que a relativização dessa imagem fixa dos estudantes "orientais" serve apenas para, de certa forma, acalmar os estudantes "brasileiros" no árduo trabalho para ingressar na universidade de seus sonhos ${ }^{160}$.

\section{Regime de manipulação: formas de intimidar e de excluir estudantes estrangeiros}

Nas últimas décadas do século $X X$, a presença de imigrantes continua a ser uma realidade no Brasil, sobretudo na cidade de São Paulo. Uma parcela considerável desses imigrantes vem com suas famílias, ou seja, cônjuges e filhos. Assim, além do trabalho, tema mais do que ressaltado em nossa tese, a imigração apresenta também um aspecto educacional dos filhos desses imigrantes. Consequentemente, o choque cultural envolvendo os filhos dos imigrantes é quase inevitável, junto com outros problemas de adaptação, de recepção e de acolhimento por parte das escolas brasileiras e de seus alunos. Existem, assim, casos em que os alunos imigrantes não são bem recebidos pela escola, sobretudo por parte dos alunos brasileiros, que não compreendem

\footnotetext{
159 Assim, resta uma dúvida: se os estudantes "asiáticos" são tão dedicados ao estudo, como eles podem não ter o domínio da língua portuguesa?

${ }^{160}$ Indo um pouco além do que a análise nos permite, entendemos que uma forma possível de se desfazer o estereótipo do estudante de origem asiática estaria na apresentação de exemplos de descendentes que se interessam pelas áreas de Humanidades e Biológicas. Além disso, outros exemplos poderiam ser apontados, como os descendentes de asiáticos que são pintores, músicos, atores, etc. para mostrar a diversidade de atividades existentes nesse grupo.
} 
e não lidam bem com a diversidade e a diferença representada pelos estudantes que chegam de outro país. Consequentemente, esses estudantes imigrantes se tornam vítimas de atos violentos e intimidatórios no cotidiano da escola. É esse o caso que analisaremos nesta seção.

Veremos exemplos da relação entre os estudantes brasileiros e os estudantes estrangeiros em uma reportagem do jornal O Estado de S. Paulo ("Jovens imigrantes levam idioma, cultura e dramas à sala de aula", publicada em 23 de março de 2008). Essa reportagem mostra, basicamente, as duas possibilidades de interação entre estudantes imigrantes e estudantes brasileiros: de um lado, uma interação que podemos chamar de "bem sucedida" porque são bem recebidos e facilmente integrados; de outro, uma interação "preconceituosa" porque baseada em uma relação de exclusão ou permeada por situações estressantes e até violentas.

Comecemos pela interação bem sucedida. A reportagem retrata a vida escolar de dois irmãos bolivianos que estudam em uma escola pública de São Paulo. Ambos parecem estar bem adaptados à escola, tanto que já falam português fluentemente, como vemos no trecho abaixo:

[Os estudantes bolivianos] Fazem os trabalhos domésticos para os pais. A escola é o momento de estudo e também de brincar. "Adoro vir para escola", diz Maysa, espontânea e com português fluente. "Gosto de tudo, gosto de estudar, e aqui posso fazer isso" (O Estado de S. Paulo, 23/03/2008: A28).

Dessa forma, falar fluentemente o português e a espontaneidade podem ser um indicativo de que essa estudante está bem integrada à escola brasileira. A reportagem indica outra característica dessa integração bem sucedida, ao menos no caso desses dois irmãos:

Com o contato, os outros alunos começaram a se interessar pelo idioma e aprenderam a dizer algumas frases básicas, usadas no começo para conversar com eles [estudantes bolivianos]. Nos corredores, ouve-se com frequência: "vamos al baño", "vamos jugar" (O Estado de S. Paulo, 23/03/2008: A28).

Ocorre, nesse caso, um processo de ajustamento mútuo, no qual o lado brasileiro adquire alguns traços da alteridade (no caso, a língua espanhola) representada pelos alunos bolivianos, que assim podem se integrar mais facilmente a esse contexto escolar. Os estudantes brasileiros se colocam no 
lugar do outro (os estudantes bolivianos) e adquirem alguns de seus traços em uma relação entre iguais.

Mas essa integração não ocorre de forma espontânea, como se poderia pensar até o momento. A integração dos estudantes bolivianos existe porque a direção e os professores agem como adjuvantes dos estudantes bolivianos, como podemos observar a seguir:

Quando chegaram, foram colocados pelo diretor na classe de uma professora filha de espanhóis, o que ajudou no início (O Estado de S. Paulo, 23/03/2008: A28).

"Tentamos tudo para inclui-los. É um desafio trabalhar valores de igualdade numa realidade em que alguns se sentem mais cidadãos do que outros", afirma Eduardo Paulo Berardi Júnior, diretor da Escola Estadual Mary Moraes, onde os irmãos estudam. "Tentamos mostrar que o mundo é maior do que o que eles (os alunos brasileiros) conhecem'” (O Estado de S. Paulo, 23/03/2008: A28).

Dessa forma, o diretor e a professora são responsáveis pela educação mais aberta ao outro e ao diferente presente nessa escola. É por essa razão que estudantes imigrantes, como os irmãos bolivianos, podem se integrar mais facilmente ao contexto escolar, auxiliando, inclusive, no seu aprendizado. Esses estudantes bolivianos encontraram, assim, um ambiente muito mais aberto e receptivo ao diferente e a quem vem de fora. Consequentemente, os estudantes brasileiros são também beneficiados com a presença de estudantes estrangeiros, que fazem perceber a existência de outra realidade cultural e linguística.

A mesma situação não se repete, infelizmente, em todas as escolas. Veremos abaixo como alunas chineses e um angolano vivem uma situação distinta da dos estudantes bolivianos.

Duas primas de origem chinesa vieram para o país junto com seus pais, saindo de Hong Kong. Depois de um tempo morando em Santos, onde trabalhava na pastelaria da família, Ana Julia (cujo nome chinês é Zhu Chunli) veio para São Paulo e passou a estudar em uma escola do bairro da Liberdade (muito conhecido por ser o bairro, inicialmente, dos imigrantes japoneses e, nos dias atuais, dos chineses e dos coreanos).

Depois de um início difícil na escola, por conta das dificuldades com a língua portuguesa, ela já consegue acompanhar com maior facilidade as aulas 
em sua escola. Mesmo, assim, Ana Júlia e sua prima enfrentam alguns problemas em relação aos estudantes brasileiros:

Há dois anos em São Paulo, onde a mãe e o pai trabalham num restaurante e o irmão vende relógios na 25 de Março (famosa rua de comércio da região central), ela se mostra mais adaptada à língua e ao conteúdo curricular. Mas ainda estranha. "Escola brasileira é legal, os professores são legais, falam bastante com a gente, mas tem muita briga", diz. "Brasileiro rouba e bate na gente", fala, envergonhada, a prima, Luo Aaoting, de 11 anos e aparência de 8 (O Estado de S. Paulo, 23/03/2008: A28).

Nessa reportagem, os estudantes brasileiros, na função de destinadormanipulador, procuram manipular os alunos estrangeiros por meio da intimidação, visando à exclusão desses destinatários de um determinado programa narrativo. A manipulação por meio da intimidação se realiza porque o destinador não aceita a diferença e porque percebe que as alunas chinesas são mais fracas. A intolerância, nesse caso, está relacionada à imposição de um contrato de exclusão, cuja existência decorre de uma imagem negativa da alteridade existente nos estudantes brasileiros, e também está ligada à própria violência física a qual elas estão submetidas.

\footnotetext{
Perdendo o receio, elas explicam: mesmo num bairro formado por descendentes de antigos imigrantes, numa cidade que cresceu graças a ondas de migrações internas e externas, sofrem preconceito, especialmente quando ainda não sabem falar português. "Não gosto quando falam que é pra eu voltar pra minha terra porque não sou daqui, nem quando roubam o dinheiro do lanche porque dizem que não gostam de chinês" (O Estado de S. Paulo, 23/03/2008: A28).
}

Observamos, pelas falas das estudantes de origem chinesa, que elas sofrem o preconceito e a intolerância de estudantes brasileiros por serem estrangeiras. Sua presença no espaço do destinador-manipulador já é considerada por si só negativa. A intolerância está também na ação em que elas foram roubadas (por conta da ação de um antissujeito que as destitui de um objeto de valor), assim como pelo fato de os estudantes brasileiros as manipularem de forma intimidatória para que elas voltem ao seu país de origem.

Além disso, o narrador desse trecho deixa claro que uma das formas de preconceito contra as estudantes chinesas é motivada pelo fato de elas não saberem falar a língua portuguesa, o que acentua o preconceito que elas já 
sofreram e ainda sofrem. O não saber falar "bem" o português serve, então, como um índice de que elas não são brasileiras e uma justificativa para serem consideradas uma alteridade indesejada. Como essas alunas não são consideradas aptas pelo destinador-manipulador (estudantes brasileiros), porque não possuem uma determinada configuração modal (a do /saber-fazer/ e a do /saber-ser/), elas são consideradas como sujeitos de outro programa narrativo e sofrem, assim, a ação de outro sujeito. Elas são, então, alvo de duas formas de intolerância: a primeira, representada pela exclusão do convívio com os estudantes brasileiros por serem estrangeiras e a segunda, pela ação de um sujeito que as destitui de um determinado objeto (quando elas são assaltadas pelos estudantes brasileiros).

Além do caso dessas estudantes chinesas, a reportagem mostra ainda 0 modo como um estudante angolano é tratado pelos estudantes brasileiros:

Na cabeça de João (nome fictício, a pedido dos pais), um angolano de 8 anos,
o conflito surge quando ouve de alunos (negros como ele) que vem de "terra de
escravo" ou que deveria "voltar pra onde fugiu". Ele diz que foi bem tratado
quando, no ano passado, começou a frequentar a rede municipal. "A escola
aqui é melhor, tem merenda, mas me chamam de nomes feios", diz. Ele não
sabe explicar porque está em São Paulo. Seus pais optam por não dar
detalhes - dizem só que não têm documentos (O Estado de S. Paulo,
23/03/2008: A28).

Ocorre, no trecho acima, uma mistura de racismo e xenofobia, uma vez que estudantes brasileiros (também de origem africana) "mandam" o estudante angolano voltar para sua terra natal. Dessa forma, os estudantes brasileiros visam, por meio da manipulação por intimidação, à exclusão do estudante angolano do espaço escolar e também do próprio país. A reportagem mostra que houve uma melhora na vida do estudante angolano depois de ter mudado de escola, mas ainda assim o aluno de origem africana continua a ouvir "nomes feios" em referência, provavelmente, à sua origem geográfica e à cor de sua pele. Em ambas as escolas, o que há (ou houve) é uma ausência de abertura dos estudantes brasileiros para a diferença (que nem é tão diferente assim, se pensarmos que a parte considerável da sociedade brasileira é constituída por descendentes de escravos africanos e também pelo fato de Angola ser um país em que se fala português, aspecto não mencionado ou que não foi considerado uma motivação para a discriminação contra o aluno angolano). 
Vimos nesta análise que parte dos problemas envolvendo alunos estrangeiros decorre do ambiente escolar pouco propício a uma educação receptiva à diferença. No caso em que a interação entre alunos brasileiros e estudantes estrangeiros foi bem sucedida, houve a presença e o esforço do diretor e de professores que ensinaram a importância da valorização da diferença e da alteridade para benefícios de todos.

De certa forma, o esforço da escola significa promover uma espécie de adaptação para os estudantes estrangeiros se sentirem bem acolhidos. Veremos, a seguir, como a ausência de um programa de adaptação prejudica a convivência entre os alunos e o seu aprendizado.

\section{Regime de ajustamento: como o descaso pode incentivar a intolerância}

A educação dos estudantes, sobretudo na escola pública, é uma responsabilidade do Estado (segundo o Estatuto da Criança e do Adolescente). A reportagem que analisaremos nesta seção mostra um amplo panorama das discriminações existentes entre estudantes. As discriminações não se resumem à imagem do imigrante, mas também à do migrante nacional ${ }^{161}$.

Estamos nos referindo a uma reportagem publicada pelo jornal $O$ Estado de S. Paulo ("Discriminação cria barreiras na convivência entre estudantes", publicada em 10 de dezembro de 2004). Essa reportagem apresenta a situação dos filhos de imigrantes nas escolas públicas. A reportagem mostra que nenhum tipo de auxílio ou de entendimento para a adaptação desses alunos é feito na maior parte das escolas. Os alunos estrangeiros ingressam, assim, na instituição sem nenhum tipo de apoio para sua adaptação, pois não são levadas em conta as especificidades deles, ou seja, eles são considerados alunos como os outros no que se refere a quaisquer questões (entendimento da matéria, avaliações, etc.).

O preconceito é apresentado pela reportagem como mais um obstáculo para quem vem para São Paulo com os pais. Um dos principais elementos que pode provocar o preconceito é o linguístico, mas também pode ser o cultural ou o físico, como vemos no trecho abaixo:

\footnotetext{
161 Mesmo não sendo o foco de nosso trabalho, consideramos importante abordar alguns traços de preconceitos que incidem sobre alunos de outras regiões do país que chegam a São Paulo para estudar.
} 
Características físicas ou culturais e até o sotaque podem fazer dos candidatos a alunos vítimas do preconceito. "As peculiaridades causam estranhamento", explica a professora da Faculdade de Educação da USP Nilce da Silva. Segundo ela, a língua serve como mecanismo de status social e um sotaque diferente pode provocar rejeição (O Estado de S. Paulo, 10/12/2004: H5).

Uma única diferença pode ser responsável pelo desencadeamento de uma postura de exclusão ou de segregação por parte dos alunos que já estão na escola e recebem outro "de fora" (sendo esse "de fora" tanto um aluno brasileiro de outra região do país ou um estudante imigrante). No entanto, o preconceito no contexto escolar não está presente apenas nos alunos. Uma das consequências desse preconceito aparece na hora de se buscar uma vaga em escolas públicas. Frequentemente, os pais estrangeiros encontram dificuldades para encontrar uma escola que tenha vagas disponíveis para seus filhos, mesmo eles sendo nascidos no Brasil:

Nas redes municipal e estadual, oficialmente, a vaga está garantida para todos, mas nem sempre a matrícula é certa. A boliviana Maria (nome fictício) tem dois filhos, de 9 e 11 anos, nascidos no Brasil. Mesmo assim, quase teve a vaga para o mais novo negada em uma escola municipal no Pari, zona norte. "Um funcionário disse que não havia lugar nem para brasileiros, muito menos para bolivianos" (O Estado de S. Paulo, 10/12/2004: H5).

Um problema que atinge a todos (a falta de vagas na escola) é reorganizado a partir da presença dos imigrantes. Se não há vagas para brasileiros, consequentemente não há vagas para bolivianos, mas o contrário não ocorreria, segundo a fala do funcionário da escola, já que ele parece estabelecer uma "ordem de prioridade" para as vagas na escola. Contudo, a versão oficial do governo é um pouco diferente. Passa-se a impressão de que as escolas públicas possuem uma educação voltada para a diversidade, para a interação com a alteridade, que deveria ser aceita e incentivada:

Segundo a diretora da Secretaria Municipal de Educação Marívia Torelli, a lei estabelece que o aluno migrante ou imigrante deve passar por avaliação. As Secretarias Estadual e Municipal não têm programas de acolhimento para quem vem de outras localidades. "Trabalhamos a diversidade cultural na escola", justifica Sônia Maria Silva, da Secretaria Estadual. Em contrapartida, a sociedade procura soluções. A ONG Presença América Latina promove aulas de espanhol a professores da rede municipal, no Pari, zona norte (O Estado de S. Paulo, 10/12/2004: H5). 
Dessa forma, a diversidade, ou seja, a abertura da escola para a diferença representada por estudantes imigrantes (ou filhos de imigrantes) seria uma política do Estado e contaria, inclusive, com a participação da sociedade (na forma de organizações não governamentais), segundo outro ponto de vista instituído na reportagem.

Como Landowski indica no regime do ajustamento, a interação entre sujeitos visa a explorar as potencialidades de ambos os lados com o intuito de produzir um novo sentido. Compreendemos que esse regime de interação pode ser encarado como um programa de adaptação dos estudantes que "vem de fora". No caso desses alunos, um período de adaptação é, assim, necessário para eles se ajustarem à nova escola, localizada em outra região brasileira ou em outro país que não o deles de origem. Contudo, a reportagem mostra que não é exatamente isso o que ocorre. Dessa forma, os estudantes estrangeiros são obrigados a acompanhar as aulas em uma língua que não é a deles e sem qualquer serviço de apoio para auxiliá-los na aprendizagem da língua portuguesa. Além disso, esses estudantes estrangeiros trazem consigo uma série de elementos e de valores culturais e linguísticos próprios que não são legitimados e aproveitados pela escola em um projeto educacional voltado para a diversidade.

Em uma situação que beira a idealização, se comparada à vivida na prática em escolas públicas, o "acolhimento" seria uma forma de ajustamento da escola em relação aos alunos de origens diversas para que eles pudessem se adaptar ao novo ambiente escolar e, assim, desenvolver suas potencialidades. Além disso, os alunos estrangeiros podem igualmente contribuir para o desenvolvimento das potencialidades dos alunos brasileiros por meio do exercício prático de uma educação mais aberta e tolerante com a diferença, ao mesmo tempo em que se valorizam as especificidades dos alunos brasileiros.

No entanto, como vimos acima, o que existe, ao menos na realidade da escola visitada pela reportagem, é a ausência de programas de acolhimento e de adaptação. Podemos entender que o descaso, tema central da reportagem, é uma espécie de punição por meio do descaso, da indiferença, do desprezo e do despreparo, ou seja, da falta de ajustamento por não reconhecer as especificidades da alteridade. 


\section{Regime do acidente: a intolerância advinda da lei}

Uma parte considerável da existência do imigrante é determinada pelo regime jurídico de um país, tanto que há uma lei específica para regulamentar seus direitos e deveres no Brasil. Por isso, uma mudança na lei pode transformar um indivíduo em um sujeito ilegal ou com a proibição de certos /fazeres/. Em outras palavras, por meio da lei é possível mudar o estatuto jurídico de um estrangeiro. É essa a dimensão da notícia que iremos analisar nesta seção.

Uma notícia veiculada no jornal Zero Hora ("Escolas paulistas expulsam estrangeiros", publicada em $1^{\circ}$ de setembro de 1994) mostra que o governo do Estado de São Paulo emitiu um decreto proibindo a matrícula de filhos de imigrantes "ilegais" na rede de educação pública e privada. A primeira intolerância é justamente aquela de que já falamos: como esses sujeitos não podem realizar um determinado /fazer/ (por estarem de forma considerada ilegal no país ou, em termos modais, por terem as modalidades do /não-poderfazer/ e /dever-não-fazer/), eles recebem uma punição. Contudo, se tomarmos o ponto de vista dos imigrantes, como é apresentado na notícia, essa proibição e essa punição tomam a forma de um acidente: assim, esses sujeitos têm suas modalidades (de /poder/, de /querer/ e de /saber/) desestabilizadas e suspensas por um acontecimento repentino que interfere em seu fazer cotidiano. As modalidades do sujeito do fazer sofrem um tipo de abalo, que interrompe o programa narrativo cotidiano do sujeito:

\footnotetext{
Em agosto do ano passado, o boliviano Edgar Guzman Huanca, na época com nove anos, estava indo muito bem na escola e já falava português melhor do que os pais, que haviam trocado a Bolívia por São Paulo em 1990. Hoje Edgar não aprende nem fala português, pois foi obrigado a voltar para a Bolívia e viver longe da família após ter sido expulso da escola onde estudava (Zero Hora, 01/09/1994: 40).

Fernando Guzman tem matado a saudade olhando uma foto de Edgar e lamenta que o filho não conheça o irmão mais novo, nascido há quatro meses. "Tirar escola de uma criança é um absurdo", reclama. Ele deixou Oruro, uma das maiores cidades da Bolívia, atrás de uma vida menos miserável (Zero Hora, 01/09/1994: 40).
} 
Além da desestabilização modal, o acidente pode também produzir a exclusão completa dos sujeitos envolvidos no programa narrativo atingido pela ruptura presente nesse regime. É isso o que ocorre com a criação do decretolei pelo governo paulista. Os filhos de imigrantes indocumentados não podem frequentar a escola e aprender, entre outras matérias, a língua portuguesa ${ }^{162}$.

A diferença dessa forma de exclusão com a que vimos acima, na relação entre as estudantes chinesas e os estudantes brasileiros, é que, nesse caso, não há uma dimensão passional clara do lado do actante que exclui os sujeitos-imigrantes. A exclusão é produzida, assim, a partir da "fria letra da lei", ou seja, apenas como um discurso racional e objetivizante. Não há, assim, contrato de qualquer natureza a ser proposto, mas apenas a imposição de uma ruptura no programa narrativo desses sujeitos.

Podemos observar, ainda, como a exclusão completa do estudante boliviano constrói o estado passional de seu pai. A saudade, neste caso, pode ser entendida como a memória da perda de alguém do convívio diário e das relações familiares que leva o pai à procrastinação e à revolta.

Os efeitos produzidos pelo acidente podem também atingir outros actantes que estão relacionados, como adjuvantes, ao programa narrativo dos imigrantes, conforme o seguinte exemplo:

Para não perder dinheiro, algumas escolas particulares de São Paulo estão tolerando a presença de filhos estrangeiros, mas estes alunos recebem um tratamento diferenciado. Eles não ganham boletins nem têm certeza quanto ao recebimento de comprovantes de estudo. Sem dinheiro para tentar encontrar uma escola particular que aceite seus filhos, Luis Godoy, 48 anos, pensa em retornar ao Chile (Zero Hora, 01/09/1994: 40).

Assim, alguns alunos apresentam um conflito envolvendo seu papel temático: são, de um lado, estudantes e como tal cumprem suas tarefas escolares; de outro, são não estudantes porque não podem exigir a contrapartida das escolas, sobretudo em questões burocráticas, como o histórico escolar, o acesso às notas entre outras. Isso, levando-se em conta que os pais da aluna citada abaixo ainda estão pagando para sua filha estudar em um colégio particular, mesmo estando de forma irregular no país. Assim,

\footnotetext{
${ }^{162}$ Diversos trabalhos indicam que o aprendizado da língua facilita a relação do estudante estrangeiro com os demais estudantes, além de permitir à criança auxiliar seus pais, no sentido de ser um "mediador", na relação com os brasileiros.
} 
mesmos pagando pela educação de sua filha, esses pais não participam da vida escolar de sua filha no próprio contexto escolar. São como sujeitos invisíveis para a escola.

A uruguaia Fabiana (foto), 15 anos, cursa $02^{\circ}$. ano do $2^{\circ}$. grau de uma escola particular na capital paulista. Mesmo matriculada há anos na escola, até hoje ela não recebeu o boletim nem algum documento comprovando sua passagem pelo colégio. "Eu nunca consigo saber as minhas notas", queixa-se a estudante. Se ela não conseguir um documento brasileiro não receberá diploma e ficará fora da faculdade. Os pais da garota sequer são convidados para as atividades na escola. "Nós apenas pagamos o colégio, não participamos de nada", relata a mãe da adolescente (Zero Hora, 01/09/1994: 40).

Mesmo na "clandestinidade", os imigrantes, enquanto sujeitos de um determinado programa narrativo, procuram retomar o seu percurso (ou seja, suas vidas) como uma tentativa de voltar à regularidade esperada e desejada de seu cotidiano. Mesmo quando impossibilitados de retornar à regularidade, os imigrantes procuram alternativas e, inclusive, outros percursos e outros /fazeres/ para, justamente, tentar fugir do "insensato" e do "não-sentido" produzidos pelo regime de acidente. Dessa forma, os imigrantes atingidos pelo decreto do governo paulista precisam adaptar sua vida a essa nova realidade. Por tentarem se manter em um programa narrativo no qual eles não são mais considerados sujeitos, os imigrantes e seus filhos passar por uma situação de exploração pelas escolas particulares, já que eles pagam para seus filhos estudarem, mas não têm uma contrapartida completa da escola (que não fornece as notas e os certificados e não permite a participação dos pais nas reuniões).

A reportagem afirma que a lei estadual se baseou no Estatuto dos Estrangeiros, foco de análise do quarto capítulo desta tese:

A expulsão de alunos de escolas paulistas foi deflagrada pela resolução número 9, de 8 de janeiro de 1990, criada ainda no governo de Orestes Quércia (PMDB). Apoiando-se na Lei dos Estrangeiros, a resolução proibia as escolas municipais, estaduais e particulares do estado de São Paulo de aceitarem filhos daqueles estrangeiros que não estivessem com toda a documentação regularizada no país ${ }^{163}$ (Zero Hora, 01/09/1994: 40).

\footnotetext{
${ }^{163}$ Infelizmente, não tivemos acesso a referida lei.
} 
Além disso, a reportagem mostra ainda que não havia qualquer tipo de pressão ou de solicitação para o governo estadual paulista tomar tal decisão. Em outras palavras, a lei foi criada de forma arbitrária e, de certa forma, com o intuito de prejudicar os imigrantes "indocumentados".

"Não havia nenhuma pressão para o governo criar esta resolução", diz Belisário dos Santos Júnior, membro da Associação dos Advogados Latino-americanos pelos Direitos Humanos. "Foi uma interpretação conservadora da lei"164 (Zero Hora, 01/09/1994: 40).

Além disso, a lei não chegou a "ser respeitada" em seu começo. As escolas ainda aceitavam alunos estrangeiros de pais "indocumentados". Contudo, a Secretaria da Educação passou a pressionar (ou seja, a manipular por meio da intimidação) as escolas a seguirem a lei imposta e, ainda segundo a reportagem, pelo menos 55 crianças foram expulsas das escolas paulistas.

Nos primeiros anos da vigência da resolução, os estrangeiros irregulares foram tolerados pelos diretores. Em 1993, a Secretaria da Educação começou a pressionar as escolas e, pelos cálculos da Pastoral do Migrante, da Igreja Católica, no mínimo 55 crianças foram expulsas. "É uma lei xenofóbica", ataca o padre Isadlo Antônio Bettin, da Pastoral do Migrante em São Paulo (Zero Hora, 01/09/1994: 40).

O acidente advindo do surgimento de uma lei que proíbe a matrícula e, consequentemente, a presença de filhos de imigrantes indocumentados na escola produz o sentimento de incerteza (/não-saber-ser/) ou da procrastinação (como no caso do estudante boliviano). Essa situação de irregularidade força os imigrantes e seus filhos a procurar outras possibilidades (inclusive, igualmente ilegais) para se adaptarem a um novo contexto até tudo voltar à sua normalidade.

\section{Considerações parciais}

Nesta seção, diferentes formas de intolerância e preconceito foram apontadas em relação aos estudantes estrangeiros e filhos de imigrantes no Brasil em situação escolar. Dessa forma, o espaço quase privado da escola

\footnotetext{
${ }^{164}$ Como dissemos no Capítulo 4, existem atualmente movimentos de imigrantes reivindicando mudanças no Estatuto do Estrangeiro.
} 
apresenta situações claras de intolerância contra estudantes estrangeiros. Além da atualização de velhos preconceitos, como os estereótipos, vimos a presença de determinados descasos sociais, como a falta de programas de adaptação para filhos de imigrantes, e formas mais claras e "tradicionais" de intolerância (como as encontradas nas falas das estudantes chinesas).

De um lado, vimos como o estereótipo do estudante de origem asiática pode produzir um efeito positivo ou negativo no estudante "brasileiro". Mas, o que nos interessa mais de perto, é a forma como o preconceito é produzido: por seu caráter redutor, o estereótipo pode ser considerado ao menos preconceituoso pelas restrições semânticas (com implicações sociais) que ele impõe à representação desse grupo de estudantes. De outro lado, vimos uma forma mais clara de intolerância envolvendo as duas estudantes chinesas. Mas a intolerância não se limita aos estudantes asiáticos ou de origem asiática. Vimos igualmente que a intolerância afeta estudantes de outras origens, como o estudante angolano, vítima de racismo por parte dos alunos brasileiros.

Parte desse preconceito e dessa intolerância na escola pode ser explicado pela falta de uma educação voltada para o respeito à diferença. Essa falta pode ser ainda exemplificada pelo próprio descaso do Estado em aplicar programas de adaptação aos estudantes que vem de outro país ou de outra região do país, que passam a ser foco, muitas vezes, de discriminação e de violência por serem considerados diferentes dos demais alunos. Nesse caso, a língua passa a ser um fator importante porque, por meio do sotaque, é possível identificar a origem de um aluno que passa a ser vítima de discriminações de todas ordens por não ser igual aos outros (ou por não falar da mesma forma).

Analisamos nessa seção algumas formas possíveis de intolerância e preconceito contra estudantes de origem estrangeira ou estrangeiros propriamente ditos. Cremos que essas rápidas análises podem nos mostrar que o fenômeno da intolerância e do preconceito, além de ainda estarem presentes nas sociedades contemporâneas, apresentam uma complexidade de formas para as quais necessitamos de um exame mais atento. As reportagens não podem ser tomadas como os únicos indícios da situação dos estudantes imigrantes no país, mas elas nos dão ao menos uma face das interações existentes há muito tempo entre a sociedade e o Estado brasileiros e os imigrantes. 


\section{Conclusões do capítulo}

Neste capítulo, vimos, basicamente, o seguinte:

a) Uma valorização dos trabalhadores imigrantes (os japoneses e os naturalizados), nas duas primeiras reportagens;

b) Exemplos de preconceito linguístico contra o imigrante japonês: na primeira reportagem, com a metáfora que se refere ao "arranhar" ou "estropiar" a língua portuguesa; na segunda, por meio da transcrição do sotaque do japonês, fato não registrado na fala dos demais imigrantes; e na reportagem sobre o estereótipo do estudante de origem asiática, cujo traço negativo é o de não dominar bem o idioma;

c) Formas mais claras de intolerância contra estudantes estrangeiros, envolvendo inclusive violência física (como o roubo sofrido pelas alunas chinesas) e simbólicas (como o xingamento contra o estudante de origem africana);

d) A construção de uma imagem positiva da sociedade brasileira, fraterna e desprovida de preconceitos, e de uma imagem negativa do Estado brasileiro, burocrático, desinteressado (pela naturalização) e omisso (em relação a programas de adaptação para estudantes estrangeiros).

De um modo geral, nenhuma reportagem apresenta argumentos contra a presença de imigrantes no país. Parece, assim, que a ideia de uma presença indesejada não faz mais parte do horizonte de perspectivas da sociedade brasileira desde ao menos o final da Segunda Guerra Mundial. Todos os imigrantes (e não esta ou aquela nacionalidade) são considerados bons trabalhadores que podem auxiliar a sociedade brasileira a se desenvolver.

Mesmo sendo esta a perspectiva geral da sociedade, casos particulares de intolerância contra estudantes estrangeiros ainda existem, como pudemos ver em nossa última análise. Se no espaço público a opinião geral é a de aceitar a presença de imigrantes, no espaço quase privado da escola, casos pontuais de intolerância persistem em um ambiente que deveria ser o de uma educação voltada para o respeito à diferença e à diversidade. 
Assim, não cabe apenas aos meios de comunicação "denunciar". É preciso que a sociedade exija da escola e dos governantes medidas para uma efetiva educação humanitária de respeito ao outro, ao diferente, ao estrangeiro. 


\section{Conclusões}

Vimos, neste trabalho, como a representação do estrangeiro em geral e do imigrante oscila de uma imagem positiva a uma imagem negativa. Mas dizer isso não é suficiente para compreendermos a complexidade das imagens construídas da alteridade pela sociedade nacional e pelo Estado brasileiro no período que começa depois de 1945 e chega aos nossos dias. Da mesma forma, as imagens da sociedade e do Estado brasileiros variaram no decorrer da segunda metade do século XX.

No momento em que a Segunda Guerra Mundial se encerrou, ainda no final da ditadura de Getúlio Vargas, a elite brasileira retomou a discussão a respeito do melhor tipo de imigrante a ser aceito pelo país. É a partir desse momento que são reconstruídas as representações do imigrante no Brasil.

De um modo geral, podemos observar a imagem positiva do estrangeiro construída pelas leis por meio dos critérios exigidos para a naturalização. As exigências da lei para um estrangeiro estabelecer o contrato de nacionalidade com o Estado brasileiro elaboram a representação de um indivíduo portador de alto nível educacional e cultural, competente para o trabalho (agrícola e industrial), com boa saúde, bom procedimento e bom comportamento. Em outras palavras, a lei constrói a imagem do "bom estrangeiro", que está em conformidade com a do "bom cidadão brasileiro", que cumpre suas obrigações e trabalha para contribuir com o desenvolvimento econômico nacional. Por isso, podemos dizer que, para essa lei, o estrangeiro que pode ser integrado à sociedade brasileira é aquele que, de certa forma, está próximo dos traços ideais da sociedade brasileira.

Além do mais, vimos nas leis que o conhecimento da língua portuguesa é um elemento, se não fundamental, ao menos presente, para que um estrangeiro se torne brasileiro. Assim, o estrangeiro que deseja se naturalizar precisa mostrar conhecimento da língua portuguesa em ao menos duas modalidades: a leitura e a escrita. A lei não deixa claro qual o nível de conhecimento linguístico exigido do estrangeiro, mesmo porque aparece uma ressalva de que devem ser observadas as condições do estrangeiro no momento da naturalização em que ele lê e escreve um trecho da Constituição perante o juiz de direito (ao menos na lei 818). A exigência de leitura e escrita 
de um trecho da Constituição não é encontrada no Estatuto do Estrangeiro. As duas leis dão margem à interpretação de que os estrangeiros que não foram alfabetizados em português ficam impossibilitados de obter a nacionalidade brasileira. Chama-nos a atenção o fato de que o Estatuto do Estrangeiro ainda mantém praticamente as mesmas exigências para naturalização presentes na lei 818 (de 1949).

A possibilidade de um estrangeiro perder a naturalização mostra uma imagem negativa do estrangeiro, presente nas leis. Essa imagem é, basicamente, a de ser uma ameaça à nação brasileira. Essa mesma imagem serve para impedir um estrangeiro de participar de atividades políticas no país ou ainda de ser proprietário de áreas consideradas estratégicas, como a indústria mineral e de navegação ou os meios de comunicação. Nos casos em que essas proibições são infringidas, o estrangeiro é punido com detenção e sua posterior expulsão do país. Outra restrição nos chamou a atenção no Estatuto do Estrangeiro: um estrangeiro que vem para o país com um contrato de trabalho determinado não pode mudar de emprego e/ou profissão e, nessa condição, não pode também mudar de residência. Para os demais casos, o estrangeiro residente no país precisa comunicar ao Ministério da Justiça seu novo endereço, fato passível de punição caso a comunicação não seja feita. $A$ imagem do estrangeiro como "ameaça" ao país é apenas uma previsão da lei em vista da defesa da integridade e dos direitos nacionais. Por isso, não podemos considerá-las intolerantes. No entanto, precisamos constatar que as duas leis (e, principalmente, o Estatuto do Estrangeiro) apresentam algumas restrições excessivas ao /fazer/ e ao /ser/ do estrangeiro no país.

Ainda em relação às leis, vimos que o Estatuto do Refugiado é uma lei mais tolerante e mesmo humanitária. O Estatuto do Refugiado mostra outra forma de estrangeiro, cuja presença, como vimos, aumenta cada vez mais no Brasil. Dessa forma, a lei constrói a imagem do refugiado como um sujeito perseguido e que teme por sua integridade física. Por conta dessa situação peculiar, a lei estabelece uma série de "privilégios" para o refugiado, como o fato de não se exigir nem documentação completa para entrar no país, nem as mesmas características do imigrante, nem o conhecimento da língua portuguesa. $O$ refugiado, na verdade, conta com uma rede de proteção e de 
assistência do próprio Brasil e de organismos internacionais presentes no país, como a ACNUR.

Optamos por examinar o Estatuto do Refugiado como uma forma de mostrar as diferenças em relação ao Estatuto do Estrangeiro e a possibilidade de uma lei menos preocupada em controlar (e até vigiar) os imigrantes e mais ativa no acolhimento dos estrangeiros que decidem se instalar no país. Assim, a existência do Estatuto do Refugiado é, para nós, mais um motivo para a mudança do Estatuto do Estrangeiro, cuja revisão está em curso com a participação, nas discussões, de associações em defesa do direito dos imigrantes no país.

Em relação às imagens do imigrante construídas pela sociedade brasileira, pudemos observar, nos textos de Côrtes e de Reis, como os critérios de seleção permitem examinar a construção da imagem positiva e negativa do imigrante. Critérios raciais e culturais são utilizados para selecionar o que alguns autores consideram como os "imigrantes desejáveis" para o país e, ao mesmo tempo, excluem outros possíveis imigrantes do processo imigratório.

O imigrante bom para o país possui as seguintes características: vontade para o trabalho e alto nível cultural e educacional. A seleção dos melhores imigrantes trata também de sua assimilação, pois o "bom imigrante" é aquele que permanece definitivamente no país. A assimilação, contudo, não objetiva apenas a integração do imigrante à sociedade brasileira. Ela serve para evitar a formação dos chamados "quistos étnicos", ou seja, comunidades estrangeiras fechadas e com pouco contato com os brasileiros. Existe também o propósito de melhorar parcela da sociedade nacional considerada atrasada e cuja existência poderia retardar o desenvolvimento econômico nacional. Assim, além de virem para auxiliar o progresso da nação brasileira, o imigrante também é utilizado para melhorar a composição étnica e cultural da parcela "menos evoluída" da sociedade brasileira. Representado como um indivíduo de características superiores ao do trabalhador brasileiro, o imigrante deve participar de um melhoramento da sociedade brasileira, como parte de um projeto que visa a alçar o Brasil ao rol das grandes potências mundiais de sua época.

Os imigrantes excluídos do processo imigratório são considerados "maus imigrantes", cuja presença atrasaria o desenvolvimento econômico 
nacional e "degeneraria" a sociedade brasileira por causa de suas características étnicas e culturais negativas. Entram no rol de "maus imigrantes" os japoneses (no texto de Côrtes), pois seriam "racialmente inassimiláveis", e os imigrantes europeus que têm problemas mentais e falta de vontade para o trabalho (nos textos de Côrtes e de Reis).

Apesar de não ser explicitamente intolerante, pois a seleção visa ao melhor para o país, vê-se uma tentativa de separar o imigrante que interessa ao país daquele que não pode ser aproveitado. Uma das críticas feitas ao governo brasileiro é, entre outras, a de manter um processo imigratório lento, burocrático e que não consegue aproveitar a "boa massa" de imigrantes que poderia ajudar o país a se desenvolver.

Caso distinto é visto no artigo de Ruth Cardoso, no qual ela estuda as estratégias de adaptação do descendente de imigrantes japoneses. Para ela, o nissei procura adquirir os comportamentos dos brasileiros nas associações juvenis para, assim, conseguir comportar-se de maneira adequada na sociedade brasileira. Essa tentativa de se comportar como um brasileiro nada mais é do que a de diminuir as diferenças culturais existentes entre brasileiros, japoneses e seus descendentes. Além disso, essa é a forma encontrada pelo nissei para ascender socialmente, expectativa existente nele e na comunidade japonesa localizada no Brasil. Dessa forma, a autora mostra um movimento de abertura dos imigrantes japoneses e de seus descendentes em direção a uma maior integração com a sociedade brasileira (não sem uma série de conflitos na própria comunidade nipônica). Vemos, assim, que a postura de Côrtes em relação ao imigrante japonês (cuja imagem, para esse autor, é o do indivíduo que não se integra à sociedade brasileira e, por isso, deve ser mantido fora do processo imigratório) começa a apresentar uma mudança, no estudo de Ruth Cardoso.

A imagem de abertura e de integração do imigrante japonês é encontrada também em uma reportagem em homenagem aos 50 anos da imigração japonesa. Essa reportagem constrói uma imagem extremamente positiva dos japoneses no país. Repleto de histórias particulares dos imigrantes japoneses no Brasil, a reportagem mostra alguns fatos que envolvem as diferenças culturais entre imigrantes japoneses e brasileiros. Mesmo com essas histórias, muitas vezes engraçadas, a reportagem elogia o trabalhador 
japonês, cujo traço de obsessão pelo trabalho permite-lhe contribuir para o desenvolvimento econômico nacional como nenhum outro trabalhador (imigrante ou brasileiro). Chama ainda a atenção o fato de a reportagem apontar, por meio de metáforas, para o problema linguístico do imigrante japonês que fala o português. Segundo a reportagem, o imigrante japonês "arranha" ou "estropia" a língua portuguesa. De qualquer forma, o problema linguístico não é tão grave, segundo a reportagem, diante dos benefícios econômicos gerados pela presença do imigrante japonês no país. Dessa forma, já no final da década de 1950, a imagem do imigrante japonês, feita pela sociedade brasileira, apresenta uma mudança significativa, pois eles não são mais considerados isolados e, na verdade, apresentam claros movimentos em direção a uma integração definitiva com a sociedade nacional, participando ativamente da esfera política, universitária, etc.

Outra reportagem apresenta também todos os benefícios advindos dos imigrantes naturalizados. Todos os imigrantes dessa reportagem são apresentados como sujeitos que conquistaram com seu trabalho o sucesso em suas respectivas áreas de atuação. Nessa reportagem, o imigrante japonês naturalizado também é representado em sua fala de um modo distinto dos demais naturalizados: sua fala, "transcrita" pela reportagem, é marcada por seu sotaque. Por essa razão, podemos dizer que há certo preconceito linguístico em relação ao imigrante japonês, na medida em que ambas as reportagem, de modos distintos, realçam as dificuldades linguísticas desses imigrantes. Dessa forma, a imagem positiva do imigrante japonês está ligada, sobretudo, ao fato de ser um ótimo trabalhador, que contribui para o desenvolvimento econômico do país.

As duas reportagens criticam o governo brasileiro, seja porque não reconhece o valor do imigrante japonês, seja porque não mostra interesse em facilitar a naturalização de outros imigrantes que desejam se tornar, oficialmente, brasileiros. Ao mesmo tempo, as reportagens mencionadas constroem, igualmente, uma imagem positiva da sociedade brasileira. Ela é uma sociedade sem conflitos, fraterna e desprovida de preconceitos raciais. Atualiza-se, assim, nas duas reportagens, a ideia da "democracia racial" brasileira, imagem que permanece até os dias atuais. 
A ideia de "democracia racial" é posta em dúvida quando analisamos algumas reportagens mais recentes que tratam da interação entre estudantes estrangeiros e brasileiros no contexto escolar brasileiro. Em alguns casos de intolerância contra o imigrante e contra os seus filhos, estava envolvida a questão linguística. Desde a violência contra estudantes chineses (cuja motivação inicial foi o fato de elas não falaram bem o português) até mostras de que o governo brasileiro não realiza efetivamente programas de adaptação para estudantes estrangeiros, a questão do preconceito e da intolerância linguística está presente, uma vez que é na escola que o filho de imigrantes pode aprender a língua portuguesa. Mas esse aprendizado é prejudicado em um ambiente que não acolhe bem o estudante que vem de outro país, seja por causa de um contato mais duro com o estudante brasileiro, seja porque não há um ensino da língua portuguesa voltado especificamente para o estudante estrangeiro. Cabe ressaltar ainda 0 ato do governo paulista que proibiu a matrícula (e a consequente presença) de filhos de imigrantes "indocumentados" na rede escolar do Estado de São Paulo. Existe nessas reportagens uma crítica ao governo brasileiro, seja pela sua ausência, seja pela decisão arbitrária que prejudicou estudantes estrangeiros no país.

A marca da imigração continua presente nas relações entre brasileiros e descendentes de alguns grupos imigrantes específicos, como os japoneses. Vimos, assim, como o descendente de imigrantes japoneses tem um estereótipo de dedicação e disciplina aos estudos. Essa imagem, não necessariamente negativa, mobiliza as paixões do medo e do temor nos demais estudantes no momento em que tentam conquistar uma vaga na universidade.

Além da dedicação e da disciplina aos estudos, o estereótipo do estudante de origem asiática também toca na questão linguística. Os estudantes dessa origem procuram, com maior frequência, os cursos de Ciências Exatas porque eles possuem dificuldades com a língua portuguesa e porque eles são excessivamente tímidos. Vemos, assim, que a dificuldade em usar a língua portuguesa é uma marca que atravessou o tempo e continua presente nos estudantes de origem asiática.

Nesse longo período de mais de cinquenta anos da retomada da imigração no Brasil, tentamos em nosso trabalho apresentar um amplo 
panorama das relações entre imigrantes, sociedade nacional e Estado brasileiro. Não temos dúvida de que muitas questões não foram contempladas neste trabalho, mesmo porque a imigração continua presente em nossos dias, com o acréscimo da entrada de uma nova forma de estrangeiro, o refugiado.

Em um mundo em constante transformação e globalizado (ao menos para alguns), quando as distâncias são cada vez menores e as referências estão disponíveis para muitos, a presença ainda atual dos imigrantes mobiliza diferentes formas de interação em que estão presentes diferentes valores e paixões. Se a situação do imigrante no Brasil não pode ser comparada à marcha contra estrangeiros existente em boa parte dos países desenvolvidos, não podemos dizer que ele é completamente bem recebido entre nós. Muito ainda há por fazer para que os imigrantes sejam verdadeiramente reconhecidos em um estatuto que está acima das nacionalidades: o de serem humanos e, portanto, com direitos que devem ser assegurados para uma vida digna, independente de sua origem geográfica, étnica, cultural, social ou linguística. Negar esses direitos a qualquer indivíduo é, para nós, um sinal de que o mundo atual não apresenta o mesmo nível de desenvolvimento encontrado em outras instâncias (como a financeira e a tecnológica).

Em resposta a essa negação, para terminarmos este trabalho, recorremos ao poeta José Paulo Paes, que nos mostra que a via para se combater as formas de exclusão, de discriminação e de segregação é a efetiva liberdade de existência da diferença:

Revidar uma negação com outra negação é fazer o jogo dela: a estrada real da liberdade não passa por aí. Passa antes pela afirmatividade da tolerância, que se empenha a cada passo em reconhecer a diferença e compreender-lhe as razões. Mesmo que não seja para adotá-las, para reconhecer-lhes direito de cidadania (Paes, 1999: 150). 


\section{Referências Bibliográficas}

\section{Fontes}

"Discriminação cria barreiras na convivência entre estudantes". O Estado de S.Paulo, 10 de dezembro de 2004, p. H5.

BRASIL. Lei no 6.815, de 19 de agosto de 1980. Disponível em: http://www.camara.gov.br.

BRASIL. Lei no 818, de 18 de setembro de 1949. Disponível em: http://www.camara.gov.br.

Brasil. Lei $n^{\circ}$ 9.474, de 22 de julho de 1997. Disponível em: http://www.planalto.gov.br.

CARDOSO, Ruth Correa Leite. "O papel das associações juvenis na aculturação dos japoneses”. Revista de Antropologia, volume 7, ns. 1/2, junho e dezembro de 1959.

CÔRTES, Geraldo de Menezes. "A Imigração". Revista de Imigração e Colonização, n. 1, março de 1947.

IWASSO, Simone. "Jovens imigrantes levam idioma, cultura e dramas à sala de aula". O Estado de S.Paulo, 23 de março de 2008, p. A28.

NASCIMENTO, Solano. "Escolas paulistas expulsam estrangeiros". Zero Hora, $1^{\circ}$. de setembro de 1994, p. 40.

NICOLETI, André. "Ameaça Amarela". Folha de S.Paulo, 5 de setembro de 2002, p. Especial 1;3.

PAGOTE, E; MORAES, Ronaldo. "O sol também nasce no Ocidente". O Cruzeiro, 14 de junho de 1958.

REIS, P. Pereira dos. "Algumas considerações sobre a imigração no Brasil". Sociologia, volume 23, n. 1, março de 1961.

RIBEIRO, José Hamilton. "Vale a pena ser brasileiro?”. Realidade, 1966.

\section{Filmografia}

HAMBURGUER, Cao (realizador) (2006). O ano em que meus pais saíram de férias [DVD]. Brasil: Buena Vista Sonopres. 
KLOCK, Kátia (realizador) (2009). Sem palavras [DVD]. Brasil: Contraponto.

\section{Bibliografia}

AHUMA, Miguel Angel (2007). "Ser imigrante no Brasil: os desafios da cidadania". Texto disponível em http://www.csem.org.br [acessado em 10/09/2011].

ALEXANDRINO, Marcelo e PAULO, Vicente (2010). Resumo de Direito Constitucional Descomplicado. Rio de Janeiro, Editora Forense/São Paulo, Editora Método. (3a. Ed.)

AMOSSY, Ruth e HERSCHBERG PIERROT, Anne (2007). Stéréotypes et clichés. Paris, Armand Colin.

ANDRADE, José H. Fischel de e MARCOLINI, Adriana (2002). "A política brasileira de proteção e de reassentamento de refugiados - breves

comentários sobre suas principais características". Revista Brasileira de Política Internacional, 45(1)Jan./Jun. 2002.

ARGENTINA (2004). Ley 346 - Ciudadania y Naturalizacion. Disponível no site http://www.hcdn.gov.ar/ [acessado em 29/09/2011]

ARKOUN, Mohammed (2000). "Tolerância, intolerância e intolerável, na tradição islâmica". In: A Intolerância. Barret-Ducrocq, F. (org.). Rio de Janeiro, Bertrand Brasil.

AURÉLIO, Diogo Pires (1996). "Tolerância/intolerância". In: Enciclopédia Einaudi (Volume 22 - Política, Tolerância/Intolerância). Portugal, Imprensa Nacional - Casa da Moeda.

BARRET-DUCROCQ, F. (org.) (2000). A Intolerância. Rio de Janeiro, Bertrand Brasil.

BARROS, Diana Luz Pessoa de (1988). Teoria do discurso: fundamentos semióticos. São Paulo, Atlas.

(2004) Projeto Intolerância e Preconceito Lingüísticos. São Paulo, mimeo.

(2007a). A identidade intolerante no discurso separatista. (Mimeo) (2007a). "Rumos da Semiótica". Revista Todas as Letras J, volume 9, n.1: $12-23$. 
(2008). "Preconceito e intolerância em gramáticas do português". In: BARROS, D.L.P. \& FIORIN, J.L. (orgs.). A fabricação dos sentidos Estudos em homenagem a Izidoro Blikstein. São Paulo, Humanitas/Paulistana Editora.

(no prelo). Discurso político e intolerância: usos e abusos.

BENVENISTE, Émile (1976). Problemas de Linguística Geral. São Paulo, Editora Nacional/EDUSP.

BERTRAND, Denis (2003). Caminhos da Semiótica Literária. Bauru, EDUSC.

BERTRAND, Denis, DÉZÉ, Alexandre e MISSIKA, Jean-Louis (2007). Parler Pour Gagner - Sémiotique des discours de la campagne présidentielle de 2007. Paris, Presses de Sciences Po.

BOBBIO, Norberto (1992). A Era dos Direitos. Rio de Janeiro, Editora Campus. (2002). Elogio da serenidade e outros escritos morais. São Paulo, Editora UNESP.

BOLAFFI, Guido; BRACALENTI, Raffaele; BRAHAM, Peter and GINDRO Sandro (2003). Dictionary of Race, Ethnicity and Culture. Londres, SAGE Publications.

BUENO, Alexandre Marcelo. Intolerância linguística e imigração. 2006. Dissertação (Mestrado em linguística) - Universidade de São Paulo, São Paulo, 2006.

(no prelo). "Filhos de imigrantes latino-americanos e asiáticos em escolas de São Paulo: casos de intolerância e de preconceito linguísticos veiculados em reportagens". In: BARROS, Diana L. P. de. Preconceito e intolerância na linguagem. São Paulo: Editora Mackenzie.

BUENO, Alexandre Marcelo, FERNANDEZ, Glauco Ortega e SILVA, Maria Rita Arêdes da (2010). Reflexões sobre o conceito de união na teoria semiótica francesa. Estudos Semióticos, Estudos Semióticos. [on-line] (Disponível em: http://www.fflch.usp.br/dl/semiotica/es) Volume 6, Número 2, São Paulo, novembro de 2010, p. 22-29. Acesso em "12/12/2010"

CANTO-SPERBER, Monique (2000). "Tolerância, neutralidade e pluralismo na tradição liberal". In: A Intolerância. Barret-Ducrocq, F. (org.). Rio de Janeiro, Bertrand Brasil. 
CARDOSO, Clodoaldo Meneguello (2003). Tolerância e seus Limites. São Paulo, Editora UNESP.

CHOI, Keum Joa (1991). Além do Arco-íris: a migração coreana no Brasil, dissertação de mestrado apresentada à Área de História Social da Faculdade de Filosofia, Letras e Ciências Humanas da Universidade de São Paulo.

(1996). "Imigração coreana na cidade de São Paulo". Rev. Inst. Est. Bras., SP, 40: 233-238.

COTLER, Irwin (2000). "Religião, intolerância e cidadania: rumo a uma cultural mundial dos direitos do homem". In: A Intolerância. Barret-Ducrocq, $\mathrm{F}$. (org.). Rio de Janeiro, Bertrand Brasil.

CUCHE, Denys (2002). A noção de cultura nas ciências sociais. Bauru, EDUSC.

DAL RI, Luciene (2001). "A construção da cidadania no Brasil: entre Império e Primeira República". Espaço Jurídico, 11(1): 7-36, jan.jun. 2010.

DIÉGUES JR, Manuel (1965). Imigração, Urbanização e Industrialização estudo sobre alguns aspectos da contribuição cultural do imigrante no Brasil. Rio de Janeiro, Centro de Pesquisas Educacionais.

DOMINGUEZ, Juliana Arantes (2004). A imigração espanhola para São Paulo no pós Segunda Guerra: Registros da Hospedaria dos Imigrantes. Dissertação (Mestrado em Sociologia) - Universidade Estadual de Campinas, Campinas, 2004.

DEZEM, Rogério (2005). Matizes do "amarelo". A gênese dos discursos sobre os orientais no Brasil (1878-1908). São Paulo, Associação Editorial Humanitas.

ECO, Umberto (2000). "Definições léxicas". In: A Intolerância. Barret-Ducrocq, F. (org.). Rio de Janeiro, Bertrand Brasil.

ESTADOS UNIDOS DA AMÉRICA (2011). A Guide to Naturalization - U.S. Citizenship and Immigration Services (USCIS). Disponível no site http://www.uscis.gov [acessado em 29/09/2011]

FALCON, Francisco José Calazans (1994). Iluminismo. São Paulo, Editora Ática.

FIORIN, José Luiz (1992). "Algumas considerações sobre o medo e a vergonha". Cruzeiro Semiótico, № 16, Jan-1992. 
(1994). Elementos de Análise do Discurso. São Paulo, Contexto.

(2009. "A construção da identidade nacional brasileira". Bakhtiniana.

Revista de Estudos do Discurso, v. 1, p. 115-126, 2009.

FIUZA, César (2008). Direito Civil: curso completo. Belo Horizonte, Del Rey.

FONTANILLE, Jacques (2007). Semiótica do discurso. São Paulo, Contexto.

FONTANILLE, Jacques e ZILBERBERG, Claude (2001). Tensão e Significação. São Paulo, Discurso Editorial/Humanitas.

FRANÇA (2011). Loi n 2011-672 du 16 juin 2011 relative à l'immigration, à l'intégration et à la nationalité. Disponível no site http://www.legifrance.gouv.fr [acessado em 29/09/2011]

FREITAS, Sonia Maria de (2001). Falam os Imigrantes: Memória e Diversidade Cultural em São Paulo. Tese (doutorado em História Social) Universidade de São Paulo, 2001.

(2007). "Migrações recentes da Ásia para o Brasil". In: Migrações Internacionais: desafios para o século XXI. Paiva, O.C. (org.). São Paulo, Memorial do Imigrante.

GREIMAS, Algirdas Julien (1981). Semiótica e Ciências Sociais. São Paulo, Editora Cultrix.

(1983). Du sens II - Essais Sémiotique. Paris, Éditions du Seuil.

GREIMAS, Algirdas Julien \& COURTÉS, Joseph (s/d). Dicionário de semiótica. São Paulo, Editora Cultrix.

(1986) Sémiotique: dictionnaire rasonné de la théorie du langage II. Paris, Hachette.

GREIMAS, Algirdas Julien e LANDOWSKI, Eric (orgs.) (1986). Análise do Discurso em Ciências Sociais. São Paulo, Global Editora.

GREIMAS, Algirdas Julien e FONTANILLE, Jacques (1993). Semiótica das Paixões. São Paulo, Editora Ática.

GIRARDET, Raoul (1987). - Mitos e Mitologias Politicas. São Paulo, Companhia das Letras.

GUIMARÃES, Antonio Sérgio Alfredo (2005). "Preconceito de cor e racismo no Brasil". Revista de Antropologia (São Paulo). São Paulo, v. 47, n. 1, p. 9 44, 2004. 
HAYDU, Marcelo (2009). "O envolvimento do Brasil com a problemática dos refugiados: um breve histórico". Revista ponto-e-vírgula, 6: 183-200, 2009.

HÉRITIER, Françoise (2000). "O eu, o outro e a intolerância". In: A Intolerância. Barret-Ducrocq, F. (org.). Rio de Janeiro, Bertrand Brasil.

HERNANDES, Nilton (2005). Semiótica dos Jornais - Análise do Jornal Nacional, Folha de São Paulo, Jornal da CBN, Portal UOL, revista Veja. Tese (doutorado em Linguística). Universidade de São Paulo, São Paulo, 2005.

HOBSBAWM, Eric (1995). Era dos Extremos - O breve século XX - 19141991. São Paulo, Companhia das Letras.

KAWADA, Junzo (2000). "O relativismo cultural em questão". In: A Intolerância. Barret-Ducrocq, F. (org.). Rio de Janeiro, Bertrand Brasil.

KELLNER, Douglas (2001). A cultura da mídia. Bauru, EDUSC

LANDOWSKI, Eric (1992). A sociedade refletida. São Paulo, Educ/Pontes. (2002). Presenças do outro. São Paulo, Perspectiva. (2004). Passions sans nom. Essais de socio-sémiotique III. Paris, PUF (2006). Les interactions risquées. Limoges, Pulim.

LE GOFF, Jacques (2000). "As raízes medievais da intolerância". In: A Intolerância. Barret-Ducrocq, F. (org.). Rio de Janeiro, Bertrand Brasil.

LEITE, Marli Quadros (2008). Preconceito e intolerância na linguagem. São Paulo, Contexto.

LEPENIES, Wolf (2000). "A intolerância - terrível virtude". In: A Intolerância. Barret-Ducrocq, F. (org.). Rio de Janeiro, Bertrand Brasil.

LESSER, Jeffrey (2008). Uma diáspora descontente - Os nipo-brasileiros e os significados da militância étnica (1960-1980). São Paulo, Paz e Terra.

LIMA, Marcus Eugênio Oliveira e VALA, Jorge (2004). "As novas formas de expressão do preconceito e do racismo". Estudos de Psicologia, 9(3): 401-411, 2004.

LUCCHESI, Dante (2002). "Norma Lingüística e realidade social". In: Lingüística da Norma. Bagno, M. (org.). São Paulo, Edições Loyola. 
MELO, Celso (2002). Curso de Direito Internacional Público. Rio de Janeiro, Editora Renovar (2 vol.).

MEMEL-FOTE, Harris (2000). "O outro e o mesmo". In: A Intolerância. BarretDucrocq, F. (org.). Rio de Janeiro, Bertrand Brasil.

MEREU, Ítalo (2000). "A intolerância institucional; origem e instauração de um sistema sempre dissimulado". In: A Intolerância. Barret-Ducrocq, $\mathrm{F}$. (org.). Rio de Janeiro, Bertrand Brasil.

MEI, Wu Xiao (2007). Linguagem, interação social e cultura: alternância de código chinês-português por imigrantes chineses no Rio Grande do Sul. Dissertação (Mestrado em Letras e Cultura Regional) - Universidade de Caxias do Sul, Caxias do Sul, 2007.

MIRANDA FILHO, Mário (s/d). "Politéia e virtude: as origens do pensamento republicano clássico". In: Clássicos do Pensamento Político. Quirino, CG; Vouga, C; Brandão; GM (org.). São Paulo, EDUSP/FAPESP. (2007). "Fronteiras da Intolerância". Protestantismo em Revista, Volume 12, jan.-abr. de 2007.

MOREIRA, Juliana Bertino (2007). "O Acolhimento dos Refugiados no Brasil: políticas, frentes de atuação e atores envolvidos". Texto disponível em http://www.abep.nepo.unicamp [acessado em 29/09/2011]

NEGAWA, Sachio (2000). Formação e transformação do bairro oriental - um aspecto da história da imigração asiática da cidade de São Paulo (19152000), dissertação de mestrado apresentada à Área de Língua, Literatura e Cultura Japonesa da Faculdade de Filosofia, Letras e Ciências Humanas da Universidade de São Paulo.

OLIVEIRA, Lucia Lippi (2001). O Brasil dos imigrantes. Rio de Janeiro, Jorge Zahar Editor. (2006). Nós e Eles - Relações culturais entre brasileiros e imigrantes. Rio de Janeiro, FGV Editora.

PAES, José Paulo (1999). O lugar do outro - Ensaios. Rio de Janeiro, Topbook.

PEREIRA, João Baptista Borges (1992). Os Estudos sobre Imigração na Antropologia Brasileira. Quaderni, v. 1, n. 2, p. 155-161.

PERES, Elena Pájaro (2003). A inexistência de terra firme - $A$ imigração galega em São Paulo (1946-1964). São Paulo, EDUSP. 
PETRONE, Maria Thereza Schorer (1982). O imigrante e a pequena propriedade. São Paulo, Editora Brasiliense.

RICOEUR, Paul (2000). "Etapa atual do pensamento sobre a intolerância". In: $A$ Intolerância. Barret-Ducrocq, F. (org.). Rio de Janeiro, Bertrand Brasil.

ROUANET, Sérgio Paulo. "O Eros da Diferença". In: Folha de São Paulo (09/02/2003).

PÓVOA NETO, Hélio (2007). Imigração na Europa - Desafios na Itália e nos países da área mediterrânica. In: PAIVA, O.C. (org.). Migrações internacionais - Desafios para o Século XXI. São Paulo, Memorial do Imigrante.

REIS, Rossana Rocha (1999). "Políticas de nacionalidade e políticas de imigração na França". Revista Brasileira de Ciências Sociais. Fevereiro, 14(39): 118-138, 1999.

(2006). "Migrações: casos norte-americano e francês". Estudos avançados, 20(57): 59-74, 2006.

SALLES, Maria do Rosário R. (2004). "Imigração, Família e redes sociais: a experiência dos 'deslocados de guerra' em São Paulo, no pós Segunda Guerra Mundial". Texto disponível em http://www.abep.org.br [acessado em 10/07/2011].

SANTOS, Joel Rufino dos (1984). O que é racismo. São Paulo, Editora Brasiliense (Coleção Primeiros Passos).

SAKURAI, Célia (2004). Tensões dentro de um mesmo grupo: os japoneses do pós-guerra e antigos imigrantes., XIV Encontro Nacional de Estudos Populacionais, Vol.14, pp.1-23, Caxambu, MG, Brasil. (2008). "A imigração japonesa para o Brasil no pós-guerra (1950-1980)". In: Cem anos da imigração japonesa - História, memória e arte. Hashimoto, F.; Tanno, J.L.; Okamoto, M.S. (orgs.). São Paulo, Editora UNESP.

SCHWARCZ, Lilia Moritz (1993). O espetáculo das raças: cientistas, instituições e questão racial no Brasil - 1870-1930. São Paulo, Companhia das Letras.

SEYFERTH, Giralda (1990). Imigração e cultura no Brasil. Brasília, Editora da Universidade de Brasília. 
SILVA, Sidney A. de (1997). Costurando sonhos - trajetórias de um grupo de imigrantes bolivianos em São Paulo. São Paulo, Paulinas.

(2005). Bolivianos - A presença da cultura andina. São Paulo, Companhia Editora Nacional/Lazuli (Coleção Imigrantes no Brasil).

(2007). "Hispânico e Latino: faces de um processo identitário entre imigrantes sul-americanos em São Paulo". In: Migrações Internacionais: desafios para o século XXI. Paiva, O.C. (org.). São Paulo, Memorial do Imigrante.

SKIDMORE, Thomas E (1976). Preto no branco: raça e nacionalidade no pensamento brasileiro. Rio de Janeiro, Editora Paz e Terra.

SOYINKA, Wole (2000). "Intolerância e direitos do homem: o preço do revisionismo". In: A Intolerância. Barret-Ducrocq, F. (org.). Rio de Janeiro, Bertrand Brasil.

SUZUKI, Teliti (1995). "A imigração japonesa no Brasil". Rev. Inst. Est. Bras., SP, 39: 57-65.

TAKEUCHI, Márcia Yumi (2007). Japoneses - a saga do povo do sol nascente. São Paulo, Editora Companhia Nacional/Lazuli (Coleção Imigrantes no Brasil).

THIESSE, Anne-Marie (2001). La création des identités nationales - Europe $X V I I I^{e}-X X^{e}$ siècle. Paris, Éditions du Seuil (Collection Points Histoire).

UNESCO (1997). Declaração de Princípios sobre a Tolerância. Brasília, Representação Brasileira da UNESCO.

WALZER, Michael (1999). Da tolerância. São Paulo, Martins Fontes.

WIESEL, Elie (2000). "Prefácio". In: A Intolerância. Barret-Ducrocq, F. (org.). Rio de Janeiro, Bertrand Brasil.

ZILBERBERG, Claude (2004). "Condições semióticas da mestiçagem". In: Olhar à Deriva - Mídia, Significação e Cultura. Cañizal, EP; Caetano, KE (orgs.). São Paulo, Annablume.

(2006). Elements de Grammaire de Sémiotique Tensive. Limoges, Pulim.

(2011). Condition de la négation. Nouveaux Actes Sémiotiques [ en ligne ]. Prépublications, 2010 - 2011 : La négation, le négatif, la négativité. Disponível no site http://revues.unilim.fr/nas (consultado em 27/03/2011). 